\title{
ESTUDO DOS PROGRAMAS DE RECICLAGEM DA USP/SÃO CARLOS E DA UFSCAR ATRAVÉS DA LOGÍSTICA REVERSA E GESTÃO DO CONHECIMENTO
}

Dissertação apresentada à Escola de Engenharia de São Carlos da Universidade de São Paulo, como parte dos requisitos para a obtenção do título de Mestre em Engenharia Civil: Planejamento e Operação de Sistemas de Transportes.

Orientador: Prof. Dr. Edson Martins de Aguiar 
Dedicatória

Dedico a Deus

E aos meus familiares 
Agradeço à Marjorie pelo companheirismo, amor e compreensão durante o período de conclusão do mestrado.

Agradeço aos meus eternos amigos Gustavo, Tiago, Alex e Mansur pela amizade e apoio durante toda minha vida.

Agradeço especialmente ao Daniel, companheiro de projeto; Bruno, Matheus e Diogo pela ajuda na pesquisa; e Flávio pela amizade.

Agradeço aos colegas de turma de mestrado pela ajuda e companheirismo.

Agradeço ao Prof. Dr. Edson Martins de Aguiar, meu orientador, pela confiança posta em mim na execução do projeto e à Prof. Dra. Liliane de Queiroz Antonio pela ajuda imprescindível no desenvolvimento e conclusão deste trabalho. Também agradeço ao Prof. Dr. Valdir Schalch pelo apoio e ajuda no trabalho.

Agradeço aos funcionários e professores do Departamento de Transportes da USP/São Carlos.

Agradeço a CNPq pela bolsa concedida durante a execução desse trabalho.

Agradeço todas as pessoas que de alguma forma contribuíram para a elaboração deste trabalho.

Meu sincero muito obrigado a todos. 
PIASSI, L. M. Estudo dos Programas de Reciclagem da USP/São Carlos e da UFSCar através da Logística Reversa e Gestão do Conhecimento. 2008. 178 p. Dissertação (Mestrado) - Escola de Engenharia de São Carlos, Universidade de São Paulo, São Carlos, 2008.

Este trabalho tem como principal objetivo o de comparar os Programas de Reciclagem de resíduos sólidos da USP campus São Carlos e da UFSCar campus São Carlos através da Logística Reversa e da Gestão do Conhecimento. A principal razão para o desenvolvimento do trabalho é identificar lacunas no fluxo de conhecimento dos programas e, de posse dos dados, sugerir melhorias nesse fluxo. O método consiste em caracterizar os programas desde sua organização até a execução do trabalho e, posteriormente, através dos dados dos questionários aplicados, identificar as possíveis lacunas no fluxo do conhecimento nos programas. As principais conclusões do presente trabalho é que ambos os programas apresentam similaridades nos processos reversos de reintrodução à cadeia produtiva dos resíduos gerados e que as lacunas existentes no fluxo de conhecimento podem prejudicar o andamento dos programas. Os métodos apresentados servem de incentivo e alerta para outros programas de reciclagem de universidades do país e para programas internos de empresas que não priorizam o gerenciamento do fluxo do conhecimento em suas instituições.

Palavras-chave: Logística Reversa; Gestão do Conhecimento; Conhecimento; Programas de Reciclagem; Gestão Empresarial; Resíduos Sólidos; Competitividade; Desenvolvimento Sustentável. 
PIASSI, L. M. Study of the USP/São Carlos and UFSCar's Recycling Programs through the Reverse Logistics and Knowledge Management. 2008. 178 p. Dissertation (Master Thesis) - Engineering School of São Carlos, University of São Paulo, São Carlos, 2008.

The main aim oh this work is to compare the recycling programs of USP campus São Carlos and UFSCar campus São Carlos using the concepts of the Reverse Logistics and Knowledge Management. The principal reason for the development of this work is to identify the gaps in the knowledge flow of the programs and, with the data, make suggestions to improve de knowledge flow. The method consists in characterize the programs since their organization until the work execution and, after that, with the data of the questionnaires, try to identify the gaps in the knowledge flow in the programs. The main conclusions of this work are that both programs show similarities in their reverse processes of reintroduction to the productive chain of the generated solid waste and that the gaps in the knowledge flow can be harmful to the programs. The presented methods serve as incentive and alert for other recycling programs of universities of the country and for internal programs of companies that not prioritize the management of the knowledge flow.

Key-words: Reverse Logistics; Knowledge Management; Knowledge; Recycling Programs; Business Management; Solid Waste; Competitiveness; Sustainable Development. 


\section{LISTA DE FIGURAS}

\section{2 - LOGÍSTICA}

Figura 2.1: A integração logística 22

Figura 2.2: Logística e o fluxo do produto 25

Figura 2.3: Hierarquia da Logística Reversa 26

Figura 2.4: Foco de atuação da logística reversa (ênfase no pós-consumo) 28

Figura 2.5: Modelo relacional entre os fatores 32

\section{3 - GESTÃO DO CONHECIMENTO}

Figura 3.1: Modelo em espiral do conhecimento 38

Figura 3.2: Duas Dimensões da Criação do Conhecimento 41

Figura 3.3: Modelo de Inteligência Organizacional 47

\section{4 - PROGRAMAS DE RECICLAGEM DA USP/SÃO CARLOS E DA UFSCar}

Figura 4.1: Tipos de coletores utilizados para a coleta seletiva de papel na USP 53

Figura 4.2: Coletor utilizado para a coleta seletiva de plásticos, metais e vidros na USP .. 54

Figura 4.3: Canecas individuais duráveis no Restaurante Universitário 56

Figura 4.4: Organização do Programa USP Recicla/Agência USP de Inovação, de acordo com a Portaria GR - 3.544, de 19 de janeiro de 2005 59

Figura 4.5: Organização do Programa USP Recicla São Carlos 61

Figura 4.6: Organização do Programa de Reciclagem UFSCar 63

\section{6 - ANÁLISE DOS RESULTADOS}

Figura 6.1: Caracterização dos gestores da USP e da UFSCar 78 
Figura 6.2: Caracterização dos gestores da USP e da UFSCar 78

Figura 6.3: Respostas para questão 01 do questionário dos gestores 80

Figura 6.4: Respostas para questão 02 do questionário dos gestores 81

Figura 6.5: Respostas para questão 03 do questionário dos gestores 82

Figura 6.6: Respostas para questão 04 do questionário dos gestores 84

Figura 6.7: Respostas para questão 05 do questionário dos gestores. 85

Figura 6.8: Respostas para questão 06 do questionário dos gestores. 86

Figura 6.9: Respostas para questão 07 do questionário dos gestores. 88

Figura 6.10: Respostas para questão 08 do questionário dos gestores 89

Figura 6.11: Respostas para questão 09 do questionário dos gestores. 90

Figura 6.12: Respostas para questão 10 do questionário dos gestores 91

Figura 6.13: Respostas para questão 11 do questionário dos gestores 93

Figura 6.14: Respostas para questão 12 do questionário dos gestores 94

Figura 6.15: Respostas para questão 13 do questionário dos gestores 95

Figura 6.16: Respostas para questão 14 do questionário dos gestores. 97

Figura 6.17: Respostas para questão 15 do questionário dos gestores 98

Figura 6.18: Respostas para questão 16 do questionário dos gestores 99

Figura 6.19: Respostas para questão Nota do questionário dos gestores 100

Figura 6.20: Caracterização dos clientes da USP e da UFSCar 101

Figura 6.21: Caracterização dos clientes da USP e da UFSCar 101

Figura 6.22: Respostas para questão 01 do questionário dos clientes 102 
Figura 6.23: Respostas para questão 02 do questionário dos clientes 103

Figura 6.24: Respostas para questão 03 do questionário dos clientes 105

Figura 6.25: Respostas para questão 04 do questionário dos clientes 106

Figura 6.26: Respostas para questão 04 do questionário dos clientes 106

Figura 6.27: Respostas para questão 05 do questionário dos clientes 107

Figura 6.28: Respostas para questão 06 do questionário dos clientes 109

Figura 6.29: Respostas para questão 07 do questionário dos clientes 110

Figura 6.30: Respostas para questão 08 do questionário dos clientes 111

Figura 6.31: Respostas para questão 09 do questionário dos clientes 113

Figura 6.32: Respostas para questão 10 do questionário dos clientes 114

Figura 6.33: Respostas para questão 11 do questionário dos clientes 115

Figura 6.34: Respostas para as Notas do questionário dos clientes 116

Figura 6.35: Caracterização dos funcionários do Programa da USP 117

Figura 6.36: Caracterização dos funcionários do Programa da USP 117

Figura 6.37: Respostas para questão 01 do questionário dos funcionários do Programa da USP 118

Figura 6.38: Respostas para questão 02 do questionário dos funcionários do Programa da USP 119

Figura 6.39: Respostas para questão 03 do questionário dos funcionários do Programa da USP 120

Figura 6.40: Respostas para questão 03 do questionário dos funcionários do Programa da USP 
Figura 6.41: Respostas para questão 04 do questionário dos funcionários do Programa da USP 122

Figura 6.42: Respostas para questão 05 do questionário dos funcionários do Programa da USP 123

Figura 6.43: Respostas para questão 06 do questionário dos funcionários do Programa da USP 124

Figura 6.44: Respostas para questão 07 do questionário dos funcionários do Programa da USP 125

Figura 6.45: Respostas para questão 08 do questionário dos funcionários do Programa da USP 126

Figura 6.46: Respostas para questão 09 do questionário dos funcionários do Programa da USP 127

Figura 6.47: Respostas para questão 10 do questionário dos funcionários do Programa da USP 128

Figura 6.48: Respostas para questão 11 do questionário dos funcionários do Programa da USP 129

Figura 6.49: Respostas para questão 12 do questionário dos funcionários do Programa da USP 130

Figura 6.50: Respostas para as Notas do questionário dos funcionários do Programa da USP

\section{7 - CONCLUSÕES}

Figura 7.1: Canais de distribuição de pós-consumo: diretos e reversos 


\section{LISTA DE TABELAS}

\section{2 - LOGÍSTICA}

Tabela 2.1: O retrato da reciclagem de resíduos sólidos urbanos em 2005 30

Tabela 2.2: Motivos estratégicos para as empresas operarem os canais reversos 31

\section{3 - GESTÃO DO CONHECIMENTO}

Tabela 3.1: Tipologia do Conhecimento 45

\section{4 - PROGRAMAS DE RECICLAGEM DA USP/SÃO CARLOS E DA UFSCar}

Tabela 4.1: Total anual Receita x Despesa x Saldo até o fim da parceria com a APASC .. 67

Tabela 4.2: Total anual e acumulado de papel e recicláveis até o fim da parceria com a APASC 68

Tabela 4.3: Total mensal de papel com a nova parceria firmada 68

\section{6-RESULTADOS}

Tabela 6.1: Agrupamento dos índices pesquisados

\section{7 - CONCLUSÕES}

Tabela 7.1: Questões relacionadas ao processo de criação do conhecimento 142

Tabela 7.2: Questões relacionadas ao fluxo do conhecimento 145 


\section{LISTA DE SIGLAS}

ABNT

APASC

BSC

CDCC

CECAE

CEMA

CEMPRE

CETEPE

CISC

CLM

CPG

CRHEA

E1

EESC

ICMC

IFSC

IQSC

KPI’s

NBR
Associação Brasileira de Normas Técnicas

Associação para Proteção Ambiental de São Carlos

Balanced Scorecard

Centro de Divulgação Científica e Cultural

Coordenadoria Executiva de Cooperação Universitária e de Atividades

Especiais

Coordenadoria Especial para o Meio Ambiente

Compromisso Empresarial para Reciclagem

Centro de Tecnologia Educacional para Engenharia

Centro de Informática de São Carlos

Council of Logistics Management

Comissão de Pós-Graduação

Centro de Recursos Hídricos e Ecologia Aplicada

Edifício 1

Escola de Engenharia de São Carlos

Instituto de Ciências Matemáticas e de Computação

Instituto de Física de São Carlos

Instituto de Química de São Carlos

Key Performance Indicators

Norma Brasileira 
ONG

PAE

PCASC

PCE

PEAm

PEV

RBC

ROCE

RRS

RRU

RU

UFSCar

UGR

USP
Organização Não-Governamental

Programa Agro-Ecológico

Prefeitura do Campus Administrativo de São Carlos

Programa de Conservação de Energia e Controle de Resíduos

Programa de Educação Ambiental

Ponto de Entrega Voluntária

Relação Benefício-Custo

Retorno Sobre o Capital Empregado

Resíduos Recicláveis Sólidos ou Secos

Resíduos Recicláveis Úmidos

Restaurante Universitário

Universidade Federal de São Carlos

Unidade de Gestão de Resíduos

Universidade de São Paulo 
1.2 - Objetivo

1.3 - Justificativa papa o estudo 13

1.4 - Estrutura do trabalho 14

2 - LOGÍSTICA 16

2.1 - Logística Integrada 22

2.2 - Logística Reversa 24

2.2.1 - Objetivos estratégicos da Logística Reversa 30

2.2.2 - Fatores críticos que influenciam a eficiência do processo de Logística reversa 32

3 - GESTÃO DO CONHECIMENTO 34

3.1 - Modelos de Gestão do Conhecimento 40

3.1.1 - Modelo de Nonaka e Takeuchi 41

3.1.2 - Modelo de Chai 44

3.1.3 - Modelo de Davenport e Prusak 45

3.1.4 - Modelo de Albrecht 47

4 - PROGRAMAS DE RECICLAGEM DA USP E UFSCAR 50

4.1 - Programa de Reciclagem da Universidade de São Paulo - USP Recicla 50

4.1.1 - Informações Gerais sobre o Programa USP Recicla 50 
4.1.2 - O Surgimento do Programa 51

4.1.3 - Objetivos 51

4.1.4 - Histórico da Coleta Seletiva na USP 52

4.1.5 - O Funcionamento da Coleta Seletiva no Campus da USP São Carlos 53

4.1.6 - Iniciativas para a Minimização de Resíduos Sólidos no Campus de São Carlos ..... 55

4.1.7 - Resultado dos Programas USP Recicla (Ano Base: 2005) ................................... 57

4.1.8 - Organização do Programa USP Recicla 58

4.2 - Programa de Reciclagem da Universidade Federal de São Carlos 61

4.2.1 - Informações Gerais sobre o Programa 61

4.2.2 - Surgimento e Estrutura Organizacional do Programa 62

4.2.3 - Objetivos do Programa 63

4.2.4 - O Funcionamento da Coleta Seletiva no Campus 64

4.2.5 - Iniciativas para a Minimização de Resíduos Sólidos no Campi 66

4.2.6 - Dados sobre a Coleta Seletiva no Campus 67

5 - MÉTODO 70

5.1 - Objetivos e justificativas 70

5.2 - Comparação dos Programas com a Logística Reversa 71

5.3 - A Gestão do Conhecimento nos Programas 72

5.4 - Estudo dos Programas 72

5.5 - Obtenção dos dados 72 


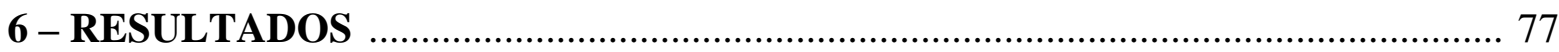

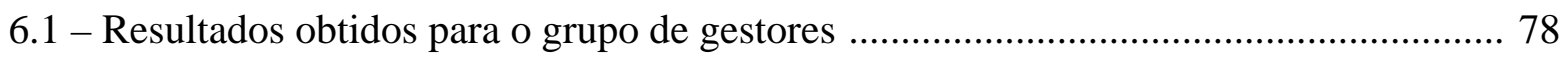

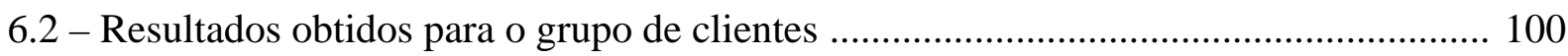

6.3 - Resultados obtidos para o grupo de funcionários ................................................. 117

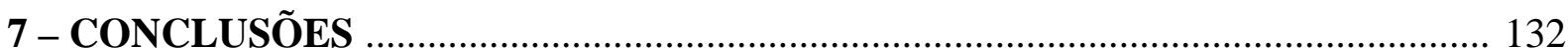

7.1 - A Logística Reversa nos programas estudados ...................................................... 132

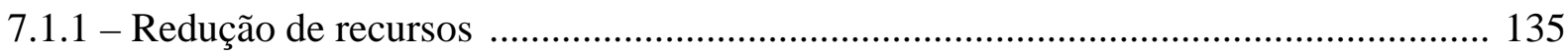

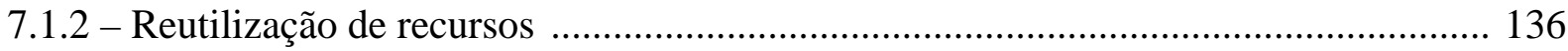

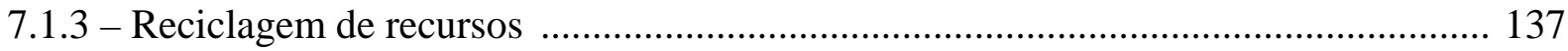

7.2 - A Gestão do Conhecimento nos programas estudados.............................................. 138

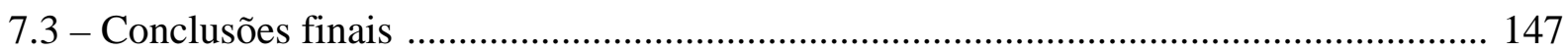

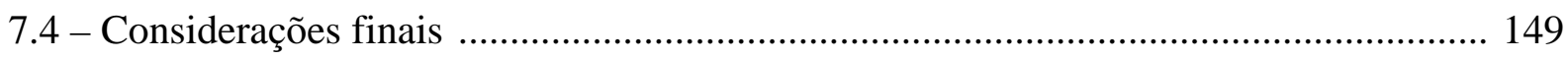

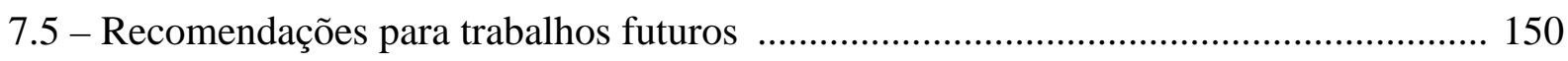

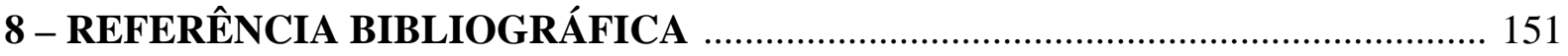

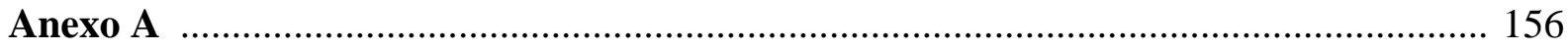

Anexo B 


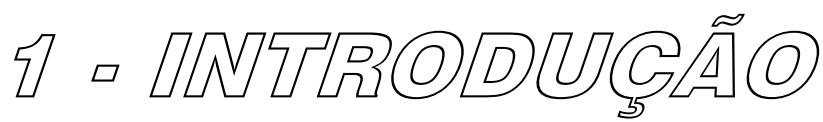

\section{1 - CONSIDERAÇÕES INICIAIS}

Com a crescente preocupação com o meio ambiente alguns programas de reciclagem foram criados nesses últimos anos em várias organizações de diferentes setores. Tais programas visam reduzir a quantidade de materiais hoje produzida e destinada à disposição final, seja em aterros sanitários e/ou lixões. Neste sentido, algumas Universidades criaram seus próprios programas de reciclagem de materiais.

Esses programas se justificam nos padrões atuais de produção e consumo, que não são sustentáveis, e no aumento crescente da população, conduzindo à geração de resíduos urbanos e industriais em quantidades cada vez maiores. É consenso dos especialistas que o descarte desses resíduos exerce pressão sobre o meio ambiente causando sérios impactos ambientais e a deterioração das condições de vida, comprometendo a saúde da população e o equilíbrio do meio ambiente.

Deste contexto a Logística surge como uma importante ferramenta no gerenciamento integrado dos resíduos permitindo a reintrodução dos materiais na cadeia de produção.

A preocupação da Logística com os canais reversos é recente e se deu principalmente por possuir grandes vantagens competitivas no ambiente consumista atual. A crescente disputa por mercados, curtos ciclos de vida de produtos, pressões legais relacionadas ao descarte de produtos, a conscientização ecológica pela difusão do 
conceito de desenvolvimento sustentável, são exemplos de fatores que determinam a necessidade do desenvolvimento do processo da Logística Reversa nos sistemas produtivos.

Com a Logística agora abrangendo não só os canais diretos de distribuição, mas também os canais reversos, há um aumento no fluxo de informações referentes às operações logísticas. Toda informação e conhecimento gerados nesse processo são de responsabilidade dos funcionários envolvidos no planejamento, bem como no seu fluxo e gestão. Além disso, no cenário atual, o da era da informação, a capacidade de mobilização e exploração dos ativos intangíveis ou invisíveis (conhecimentos, competências, relacionamentos, informações estratégicas e outros) tornou-se muito mais decisiva do que investir e gerenciar ativos físicos tangíveis.

É nesse contexto que a Gestão do Conhecimento se insere, visando contribuir para que as informações gerem conhecimento e para que esse conhecimento seja aplicado, armazenado e distribuído e/ou compartilhado na organização.

Segundo Triska (2001, p. 02), a Gestão do Conhecimento promove a formalização do enquadramento do conhecimento individual de seus colaboradores ao cotidiano da organização como um todo, considerando seus ambientes interno e externo.

Para Linke (2001, p.04), de modo que isso possa ocorrer no ambiente de uma organização, faz-se necessário um estudo do processo da gestão do conhecimento, da cultura e dos valores organizacionais, bem como do processo de aprendizagem organizacional, para valorizar o conhecimento humano, criando assim o conhecimento organizacional. 
Esse estudo envolve conhecimentos sobre a cultura da empresa em relação à gestão do conhecimento, como se opera o processo de troca de informações, bem como a análise de ambiente, observando se pode ser considerado propício para a criação, disseminação e gerenciamento do conhecimento.

\section{2 - OBJETIVO}

O objetivo principal deste trabalho é analisar a forma pela qual o fluxo de informação e conhecimento apresenta-se nos programas de Reciclagem em duas Universidades, USP e UFSCar. Desta forma, os programas de reciclagem serão analisados utilizando-se os conceitos de Gestão do Conhecimento, compostos por conhecimento aplicado, criado, armazenado e distribuído, e que visa, entre outros objetivos, aperfeiçoar a criação e o fluxo de conhecimento em uma organização, não deixando de lado o contexto da Logística Reversa.

\section{3 - JUSTIFICATIVA PARA O ESTUDO}

As universidades são instituições com grande visibilidade na sociedade, e seus programas têm grande influência em outras organizações. Como os atuais programas de reciclagem buscam melhorias e reformulações em sua cadeia com a finalidade de ganho em imagem corporativa, atendimento às legislações ambientais, viabilidade econômica para o seu funcionamento, entre outros, são abordadas as técnicas e conhecimentos que atinjam esses objetivos e traduzam a visão estratégica da empresa.

A utilização da Gestão do Conhecimento objetiva a melhoria dos processos de criação e aprendizado. Com isso existe um alinhamento da Gestão do Conhecimento com os princípios das Universidades escolhidas para o estudo de caso, que é o de gerar conhecimento. 
Assim, como objetos de estudo, foram escolhidos os programas das universidades UFSCar e USP, pelo fato da comunidade geradora de resíduos, dos produtos consumidos, da estrutura organizacional, da localização e destino dos resíduos serem similares.

O estudo proposto, além de servir de incentivo para programas de outras universidades do país como estímulo a gestão do conhecimento, também é importante para programas de empresas preocupadas com o gerenciamento de seus resíduos sólidos.

Outro ponto fundamental desses programas é o enfoque nas duas maiores universidades de São Carlos, ou seja, devido à grande concentração de pessoas e sua alta rotatividade, amplia a necessidade de disseminação do conceito do consumo responsável e sustentável, fazendo com que estudantes, sociedade circunvizinha aos campi e funcionários, expandam os bons exemplos aprendidos em seus ambientes de casa, lazer e trabalho, promovendo a sustentabilidade.

\section{4 - ESTRUTURA DO TRABALHO}

O presente trabalho encontra-se dividido em sete capítulos:

- Capítulo 1 - neste capítulo é feita a apresentação do trabalho, sua introdução e são descritos os objetivos e justificativas para o estudo do tema referido.

- Capítulo 2 - neste capítulo é feita a revisão bibliográfica do trabalho em relação à Logística, apresentando definições e características. 
- Capítulo 3 - neste capítulo é feita a revisão bibliográfica do trabalho em relação à Gestão do Conhecimento, apresentando definições e características.

- Capítulo 4 - neste capítulo é feito o levantamento dos programas de reciclagem comparando-os à Logística Reversa, analisando seu tipo de organização, origem dos recursos, estrutura, metas, métodos de trabalho, etc.

- Capítulo 5 - neste capítulo é feita a apresentação do método utilizado na pesquisa entre as diversas abordagens da Gestão do Conhecimento.

- Capítulo 6 - neste capítulo é feita a apresentação dos resultados obtidos com a coleta de dados.

- Capítulo 7 - neste capítulo é feita a apresentação das conclusões obtidas com a coleta de dados e informações nos programas de reciclagem estudados sob os conceitos da Logística Reversa e da Gestão do Conhecimento. 
O termo Logística já é utilizado há muitas décadas; os militares do século XIX já utilizavam esta palavra que "significava" a arte de transportar, abastecer e alojar tropas. Com o tempo, passou a ser utilizado também pela indústria, com um significado ampliado, de ser a arte de administrar o fluxo de materiais e produtos, da fonte para o usuário (BALLOU, 1993).

De maneira geral, o objetivo da Logística é tornar disponíveis produtos e serviços no local onde são necessários, no momento que são desejados, atingindo um nível desejado de serviço ao cliente ao menor custo possível (BOWERSOX \& CLOSS, 2001).

Ainda, segundo Bowersox \& Closs (2001), tanto o interesse quanto as novidades relacionadas à logística têm origem na combinação de áreas tradicionais numa iniciativa estratégica integrada. A logística envolve desta forma, a integração de informações, transporte, estoque, armazenamento, manuseio de materiais e embalagem.

Os autores acima citados ainda afirmam que o que faz a logística contemporânea interessante é o desafio de tornar os resultados combinados da integração interna e externa numa das competências da empresa, e que a logística de uma empresa é um esforço integrado com o objetivo de ajudar a criar valor para o cliente pelo menor custo total possível. A logística existe para satisfazer às necessidades do cliente, facilitando as operações relevantes de produção e marketing. 
Segundo Ballou (1993), um estudo mais detalhado pode mostrar que o desenvolvimento histórico da logística empresarial se deu principalmente em três eras: antes de 1950, de 1950 a 1970 e após 1970.

Até 1950 não existia nenhuma definição concreta de Logística. Nas empresas, o transporte - uma das atividades primárias - era gerenciado freqüentemente pelo departamento da Produção, enquanto o estoque era controlado pelo Marketing, Finanças ou Produção e o processamento de pedidos era responsabilidade do pessoal de Vendas ou Finanças. Esta divisão geralmente causava conflitos entre os departamentos e muitas vezes desacordos entre as partes.

Segundo Ballou (1993), os pioneiros que identificaram a importância da distribuição física nas empresas foram Arch Shaw, em 1912 e Fred Clark, em 1922. A partir de tais estudos houve reagrupamentos das atividades e replanejamentos gerenciais, surgindo assim, a área específica de Logística dentro das empresas. Após a Segunda Guerra Mundial, a economia norte-americana cresceu rapidamente e o objetivo era de vender e produzir, mas para isso, a distribuição precisava ser levada em consideração para não dificultar as negociações.

A partir do início da década de 50 até os anos 60 houve um grande desenvolvimento da teoria e também da prática da Logística. Em 1954 um renomado professor de Marketing, chamado Paul Converse, afirmou que as empresas precisariam dar mais atenção à questão da distribuição ao invés de só se preocupar com compras e vendas. Peter Drucker, famoso consultor de administração de empresas, considerou as atividades de distribuição física áreas de negócios desprezadas, porém promissoras, na América. 
Posteriormente, passou-se a estudar profundamente os custos geridos de estoques e transportes, as vantagens e desvantagens pela escolha de determinados tipos de transportes ou rotas e maneiras para sua redução. Desenvolveu-se então o conceito de custo total. Este conceito tornou-se um importante argumento para um reagrupamento lógico de atividades de distribuição que estava ocorrendo nas empresas pioneiras e tem como foco principal a inter-relação entre custos funcionais do que a análise destes custos individualmente.

$\mathrm{Na}$ época tratada, as condições econômicas e tecnológicas eram tais que influenciaram muito o desenvolvimento da disciplina. Algumas dessas condições eram: alterações nos padrões e atitudes da demanda dos consumidores, pressão para redução de custos nas indústrias, avanços na tecnologia de computadores e influências das experiências militares com logística (BALLOU, 1993).

A prática logística passou por um renascimento que envolveu muitas mudanças a partir da década de 70 , mas principalmente nas décadas de 80 e 90 . Os mecanismos propulsores mais importantes destas mudanças foram: uma significativa mudança nas regulamentações, a comercialização de microcomputadores, a revolução da informação, a adoção dos movimentos da qualidade, o desenvolvimento de parcerias e alianças estratégicas (BOWERSOX \& CLOSS, 2001). Assim, com todas estas mudanças, surgiu a logística integrada, que deixou de se preocupar apenas com a distribuição física, mas integrou a esta atividade a administração de materiais.

No final da década de 90, o conceito de logística ampliou-se com o desenvolvimento da Logística Reversa.

A logística reversa tem sido citada com freqüência e de forma crescente em livros modernos de logística empresarial, em artigos internacionais e nacionais, 
demonstrando sua oportunidade, aplicabilidade e interesse em diversos setores empresariais (LEITE, 2002). Este assunto será tratado mais adiante neste trabalho.

\section{ATIVIDADES DA LOGÍSTICA}

A integração dos elos da cadeia produtiva, segundo Ballou (1993), conduz à ligações cada vez mais estreitas, tornando a produção muito próxima da logística, tanto no conceito quanto na prática.

A Logística Empresarial explica como a gerência de uma empresa pode prover maior rentabilidade nos serviços de distribuição aos clientes e consumidores, através do planejamento, organização e controle efetivos para as atividades de movimentação e armazenagem, com o intuito de facilitar o fluxo de produtos desde o ponto de aquisição da matéria-prima até o consumidor final, assim como os fluxos de informações. O grande desafio da Logística é diminuir o hiato entre a produção e a demanda, para que os consumidores tenham bens e serviços quando, onde e como desejarem, ao menor preço possível, uma vez que tanto os recursos quanto os consumidores estão espalhados numa ampla área geográfica como no caso do Brasil.

A Logística tenta agrupar as atividades relacionadas ao fluxo de produtos e serviços para controlá-las e coordená-las de forma conjunta. Estas atividades podem ser classificadas em dois tipos de atividades: as primárias e as de apoio. Segundo Ballou (1993), as atividades primárias contribuem com a maior parcela para o custo total da Logística. As atividades classificadas como primárias são as seguintes:

- Transporte, esta atividade é essencial porque é responsável pela movimentação física dos produtos como matérias-primas ou peças acabadas. A administração desta atividade decide quanto aos métodos de 
transporte, roteiros e utilização da capacidade do veículo, levando em consideração custo, confiabilidade e desempenho operacional. Esta atividade adiciona valor de "lugar" ao produto.

- Manutenção de estoques, esta atividade serve para equilibrar o estoque, permitindo que este não seja tão elevado (para minimizar os custos de estoque), mas também seja suficiente para atender à demanda prevista. Enquanto o transporte agrega valor de "lugar" ao produto, a manutenção de estoque agrega valor de "tempo" ao mesmo.

- Processamento de pedidos, a atividade que inicializa a movimentação de produtos e a entrega de serviços.

Como o resultado final de qualquer operação Logística é prover serviços ou mercadorias para os seus clientes quando, onde e como eles quiserem, e estas três atividades são centrais para cumprir a missão. Entretanto há outras atividades que dão apoio a estas, como:

- Armazenagem: esta atividade diz respeito à administração do espaço necessário para manter o estoque. Os problemas que devem ser resolvidos pelo gerente desta área são: localização, dimensionamento de área, arranjo físico, recuperação de estoque, projetos de docas e configuração do próprio armazém.

- Manuseio de materiais: esta também apoia a manutenção de estoques. Ela refere-se à movimentação do produto no local de estocagem. As principais dificuldades para o gerente desta atividade são: seleção de 
equipamento de movimentação, procedimentos para formação de pedidos e balanceamento de carga de trabalho.

- Embalagem de proteção: esta atividade se preocupa em projetar embalagens que permitam a movimentação de mercadorias sem danificálas e também que sejam economicamente viáveis.

- Obtenção: atividade que disponibiliza o produto para todo o sistema logístico. Refere-se à seleção das fontes de suprimento, das quantidades a serem adquiridas, da programação de compras e da forma que é efetuada a compra.

- Programação do produto: esta atividade lida com o fluxo de saída dos produtos (distribuição), ou seja, com as quantidades agregadas que devem ser produzidas e quando elas devem ser fabricadas.

- Manutenção de informação: esta atividade é importante para manter a base de dados com informações importantes para planejamento, desempenho e controle da Logística. 


\section{1 - LOGÍSTICA INTEGRADA}

“A Logística é vista como a competência que vincula a empresa e seus clientes e fornecedores" (BOWERSOX \& CLOSS, p. 43, 2001). Como representado na figura 2.1.

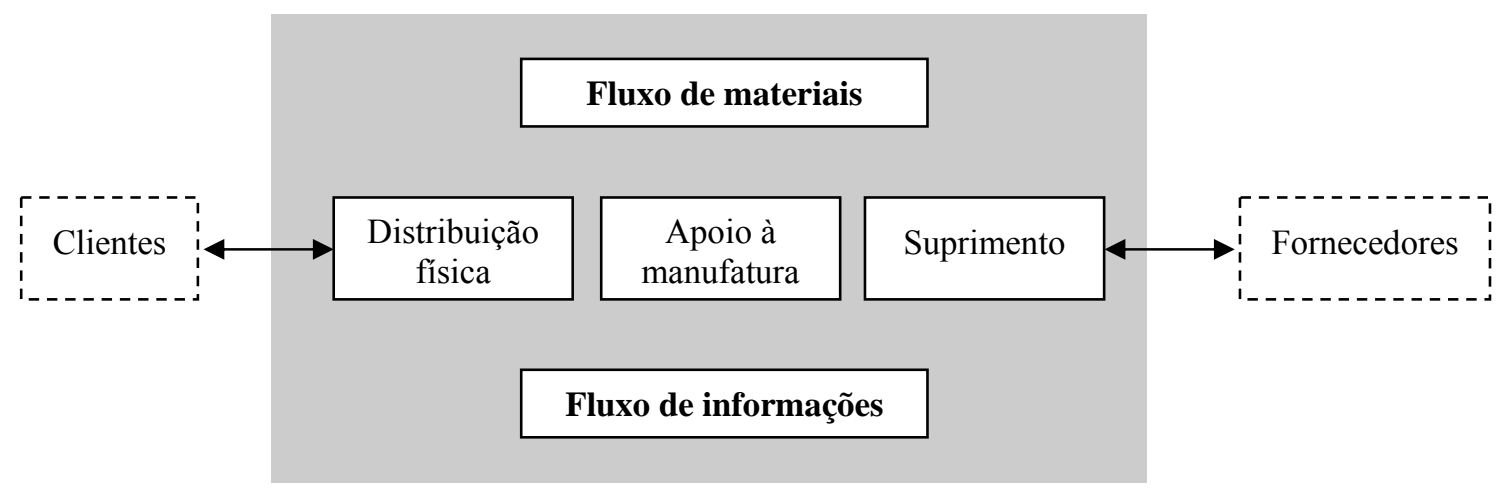

Figura 2.1: A integração logística

Fonte: BOWERSOX \& CLOSS (2001)

Ainda, de acordo com os autores, as informações recebidas de clientes fluem na empresa na forma de atividades de vendas, previsões e pedidos. As informações são filtradas em planos específicos de compras e de produção. No momento do suprimento de produtos e materiais, é iniciado um fluxo de bens de valor agregado que resulta, por fim, na transferência de propriedade de produtos acabados aos clientes. Assim, o processo tem duas ações inter-relacionadas: fluxo de materiais e fluxo de informações.

Antes de abordar cada fluxo, Bowersox \& Closs (2001) atentam que duas observações são necessárias:

1. A consideração de operações internas (área sombreada da Figura 01) isoladamente é útil para mostrar a importância fundamental da integração de todas as funções e atividades envolvidas na logística.

2. O processo básico ilustrado na Figura 01 não se restringe a empresas com fins lucrativos, nem é exclusivo de empresas industriais. A urgência 
de integrar necessidades e operações ocorre em todas as empresas, assim como em organizações do setor público.

Fluxo de materiais

O gerenciamento operacional da logística abrange a movimentação e a armazenagem de materiais e produtos acabados. As operações logísticas têm início com a expedição inicial de materiais ou componentes por um fornecedor, e terminam quando um produto fabricado ou processado é entregue ao cliente.

A partir da compra inicial de materiais ou componentes, o processo logístico agrega valor movimentando o estoque quando e onde é necessário, até chegar ao consumidor final.

As operações logísticas podem ser divididas em três diferentes áreas: distribuição física, apoio à manufatura e suprimento.

- Distribuição física: esta área trata da movimentação de produtos acabados para entrega aos clientes. É o vínculo entre fabricantes, atacadistas e varejistas e também consumidor final.

- Apoio à manufatura: esta área concentra-se no gerenciamento de estoque em processo à medida que este flui entre as fases de fabricação. A principal responsabilidade da logística na manufatura é participar da formulação de um programa-mestre de produção e providenciar a disponibilidade de materiais e componentes em tempo hábil.

- Suprimento: esta área abrange a compra e a organização da movimentação de entrada de materiais, de peças e de produtos acabados 
dos fornecedores, para as fábricas ou montadoras, depósitos ou lojas de varejo.

Enfim, o ponto central do processo logístico integrado é a coordenação geral da movimentação de estoque de valor agregado. A combinação das três áreas propicia o gerenciamento integrado da movimentação de materiais, de componentes semiacabados e de produtos entre instalações, a partir de fontes de suprimento, para atendimento final aos clientes (BOWERSOX \& CLOSS, 2001).

\section{Fluxo de informações}

O objetivo do compartilhamento de informações entre as áreas operacionais da logística é resolver as diferentes necessidades de movimentação segundo o porte dos pedidos, a disponibilidade de estoques e a urgência de atendimento. É importante enfatizar que as necessidades de informações seguem caminhos paralelos ao trabalho real executado na distribuição física, no apoio à produção e no suprimento.

\section{2 - LOGÍSTICA REVERSA}

Via de regra se pensa em logística como o gerenciamento do fluxo de materiais desde seu ponto de aquisição até seu ponto de consumo. Entretanto, existe também o fluxo reverso, que parte do ponto de consumo até o de origem, e este fluxo também precisa ser gerenciado. Surge assim, a necessidade de uma logística reversa (Lacerda, 2002). Vide figura 2.2. 


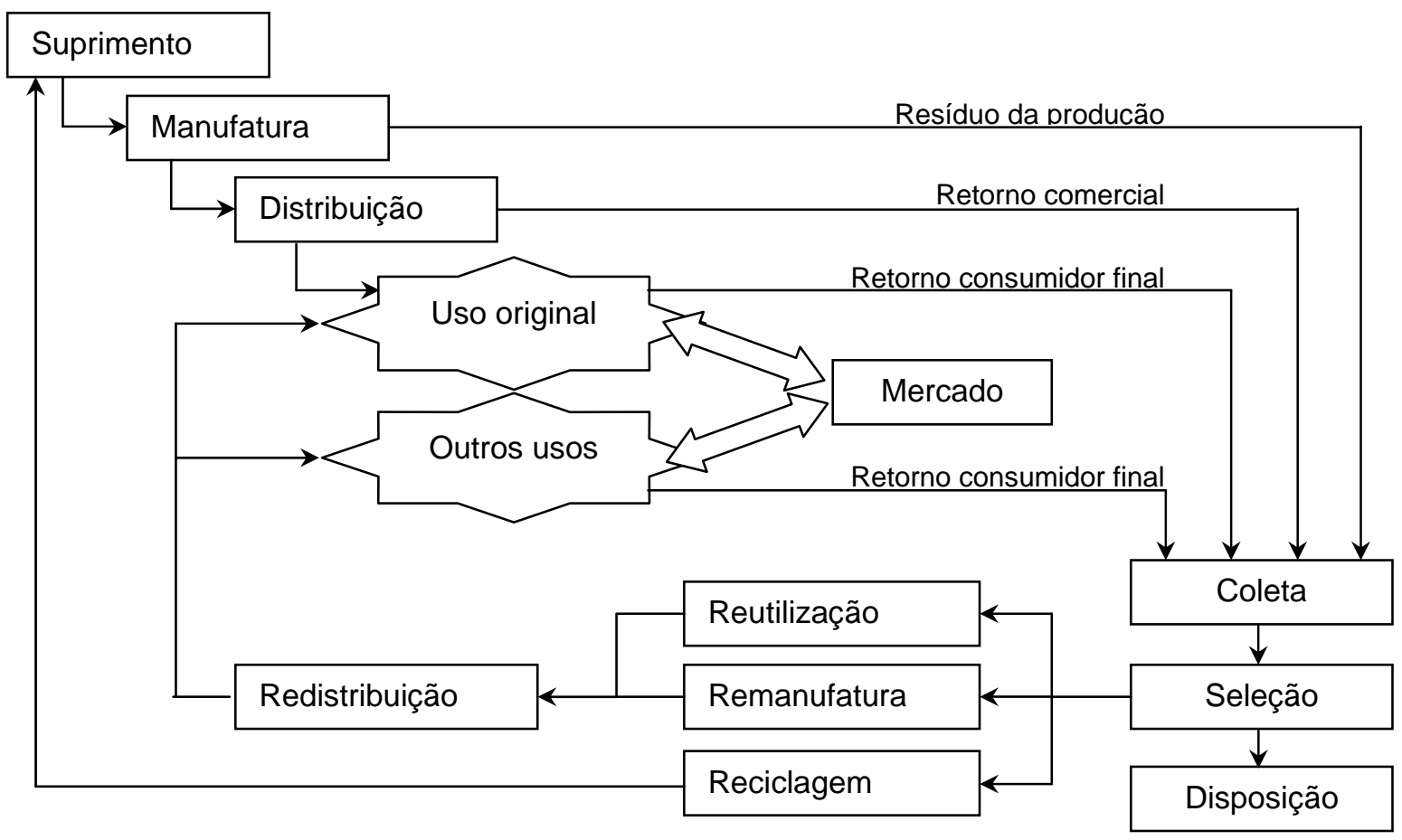

Figura 2.2: Logística e o fluxo do produto. Aguiar, E. M. (2007)

Em C.L.M. (1993, apud Leite 2002), a definição de Logística Reversa é: "Logística reversa é um amplo termo relacionado às habilidades e atividades envolvidas no gerenciamento de redução, movimentação e disposição de resíduos de produtos e embalagens..."

Rogers e Tibben-Lembke (1998) definem a logística reversa como "processo de planejamento, implementação e controle de eficiência, do custo efetivo de fluxo de matérias-primas, estoques de processo, produtos acabados e as respectivas informações, desde o ponto de consumo até o ponto de origem, com o propósito de recapturar valor e adequar o seu destino."

C.L.M. - COUNCIL OF LOGISTICS MANAGEMENT (1993). Reuse and Recycling Reverse Logistics Opportunities. Illinois: Council of Logistics Management. 
A logística reversa, para Carter e Ellram (1998 apud Marques; Ferreira; Aguiar, 2002, p. 5) deve obedecer a uma hierarquia, em que a redução de recursos deve ser o principal objetivo. Esta redução refere-se à minimização dos resíduos e energia. Através da redução de recursos, o fluxo normal e o reverso de materiais seriam minimizados. Uma vez esgotada a opção de redução de recursos, deve-se tentar a maximização da reutilização, seguida da reciclagem. A disposição em aterros, de preferência, sanitários, sem qualquer forma de recuperação deve ser a última opção. As empresas podem ainda optar em dispor seus produtos através da incineração, com alguma forma de recuperação de energia. Esta hierarquia é resumida na Figura 2.3.
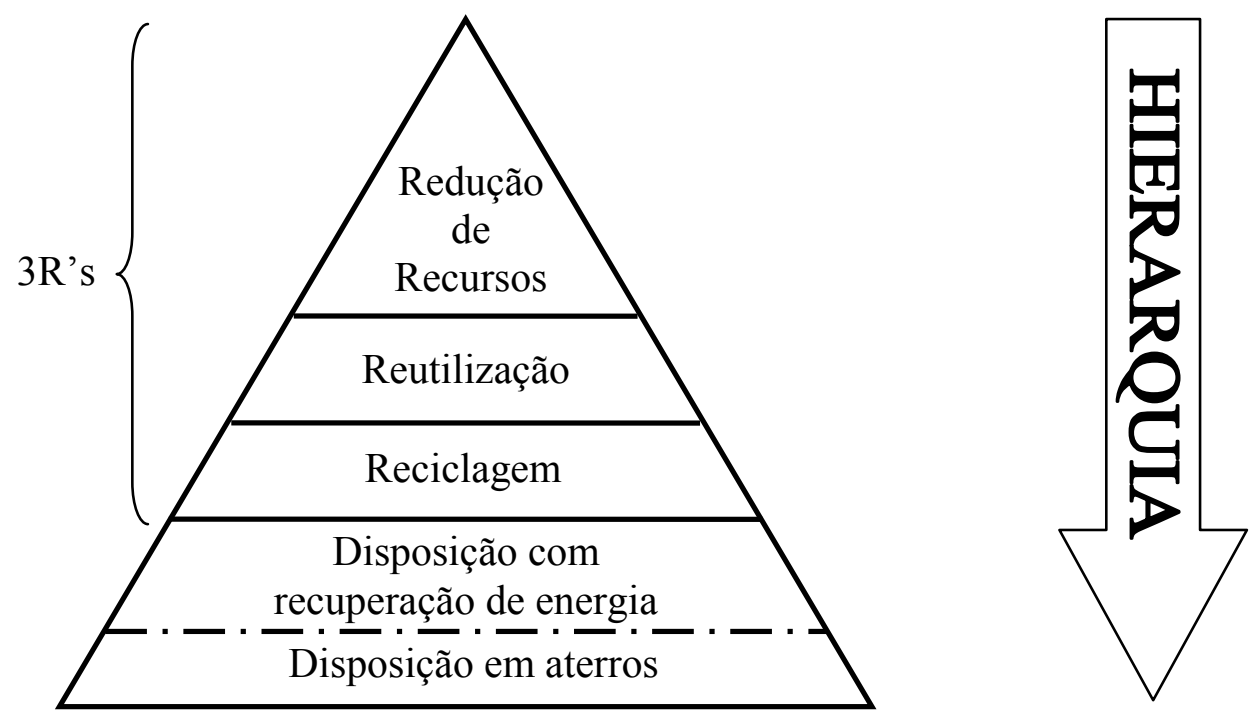

Figura 2.3. Hierarquia da Logística Reversa.

Fonte: Adaptado de Carter e Ellram (1998 apud Marques; Ferreira; Aguiar, 2002, p. 5).

Carter, C. R.; Ellram, L. M. (1998). Reverse Logistics: A review of the literature and framework for future investigation. Journal of Business Logistics, vol.19, n.1, p.85-103. 
Leite (2002) fornece um conceito de logística reversa levando em consideração todas estas definições previamente estudadas. $\mathrm{O}$ autor entende logística reversa como sendo:

“A área da logística empresarial que planeja, opera e controla o fluxo e as informações logísticas correspondentes, do retorno de bens de pós-venda e de pós-consumo ao ciclo de negócios ou ao ciclo produtivo, por meio dos canais de distribuição reversos, agregandolhes valores de diversas naturezas: econômico, ecológico, legal, logístico, de imagem corporativa, entre outros". (LEITE, p. 16-17, 2002).

A logística reversa, segundo a definição de Leite (2002), atua em duas grandes áreas que podem ser diferenciadas pelo estágio ou fase do ciclo de vida útil do produto retornado, apesar de inúmeras interdependências entre elas. Estas áreas são: logística reversa de pós-venda e de pós-consumo.

A logística reversa de pós-venda se refere ao equacionamento e operacionalização do fluxo físico e das informações logísticas correspondentes de bens de pós-venda, sem uso ou com pouco uso, que, por diferentes motivos, retornam aos diferentes elos da cadeia de distribuição direta. O objetivo estratégico desta logística é o de agregar valor a um produto que é devolvido por razões comerciais como erros de processamento dos pedidos, garantia dada pelo fabricante, defeitos ou falhas de funcionamento no produto, problemas no transporte, entre outros motivos.

A logística reversa de pós-consumo equaciona e operacionaliza o fluxo de materiais e de informação correspondentes de bens de pós-consumo descartados pela sociedade, que retornam ao ciclo produtivo pelos canais de distribuição reversos específicos. São bens de pós-consumo aqueles produtos em fim de vida útil ou usados com a possibilidade de reutilização. O objetivo estratégico desta logística é agregar 
valor a um produto que não é mais utilizado pelo usuário original, mas que possui condições de ser reutilizado, ou a um produto descartado por ter atingido o fim de sua vida útil. Os produtos de pós-consumo podem fluir por canais reversos de reparo, remanufatura ou reciclagem até o destino final.

A figura 2.4 ilustra resumidamente o campo de atuação da logística reversa por meio das principais etapas dos fluxos reversos nas duas áreas de pós-venda e de pósconsumo.

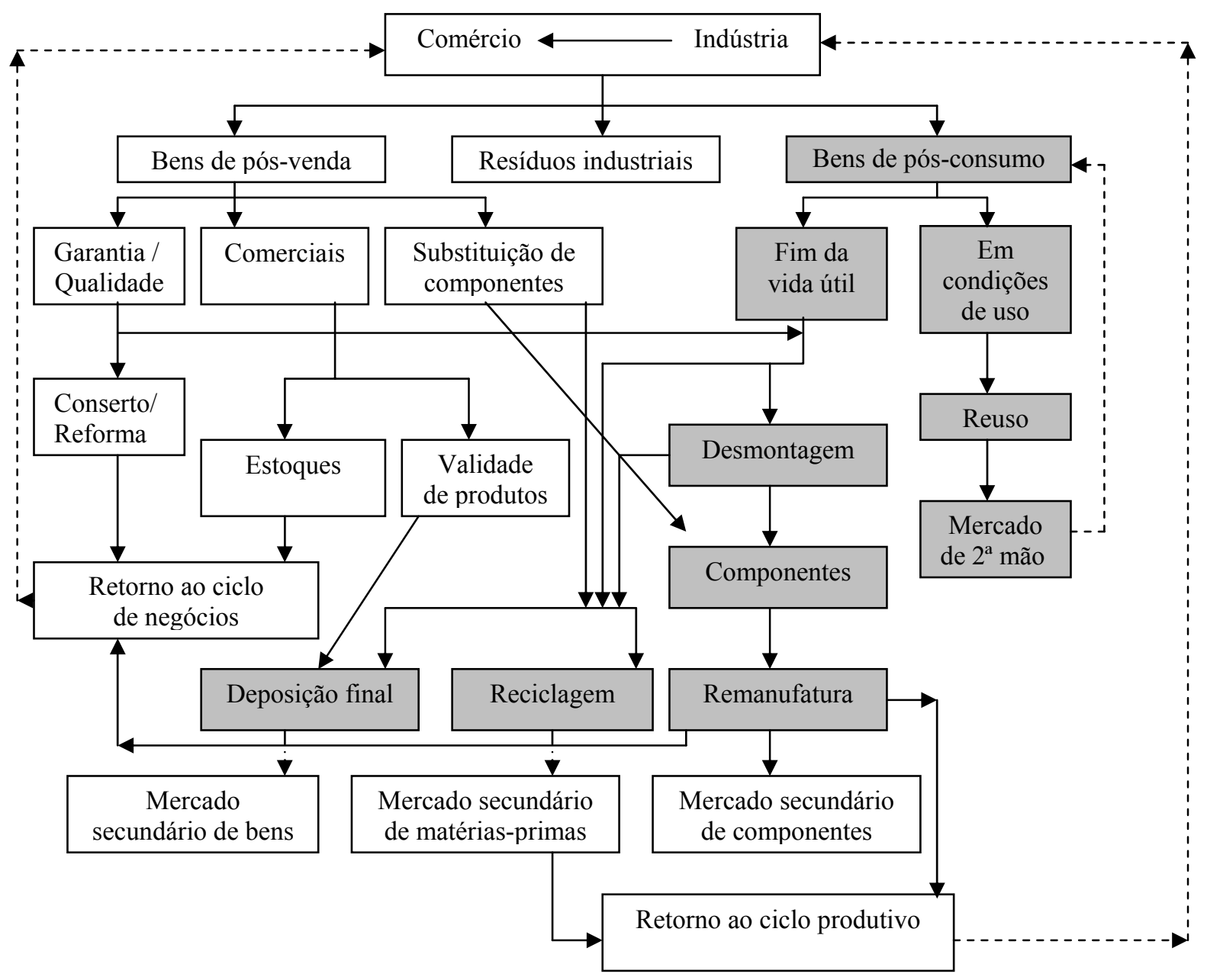

Figura 2.4: Foco de atuação da logística reversa (ênfase no pós-consumo) Fonte: LEITE, 2002 (adaptada) 
No presente trabalho será discutido apenas a logística reversa de pós-consumo que é o foco da pesquisa em questão.

A logística reversa de pós-consumo planeja, opera e controla o fluxo de retorno de produtos, peças ou componentes que já foram usados pelos consumidores e devem ser reaproveitados tanto na remanufatura ou reciclagem. São classificados conforme seu estado de vida ou origem:

"Em condições de uso" são os produtos que entram no canal reverso de "Reuso" e assim têm sua vida útil estendida. Estes produtos são comercializados no mercado de segunda mão até esgotarem sua vida útil. Quando isso ocorre, passa a ser um produto classificado como "Fim de vida útil". (LEITE, 2002)

Estes produtos são desmontados, remanufaturados e remontados novamente para serem novamente comercializados. Dependendo do tipo e da condição em que o produto retornado se encontra, ele é reciclado e usado como matéria-prima ou então descartado (destinado aos aterros sanitários, lixões e incineração com recuperação energética), ao invés de ser remanufaturado.

$\mathrm{Na}$ tabela abaixo pode-se ver o retrato da reciclagem de resíduos sólidos no Brasil. 
Tabela 2.1. O retrato da reciclagem de resíduos sólidos urbanos em 2005

\begin{tabular}{ccc}
\hline Tipo de Material & Volume (em ton.) & Índice de reciclagem \\
\hline Papel de escritório (ofício branco) & 882.400 & $49,5 \%$ \\
Papelão & 2.237 .000 & $77,4 \%$ \\
Plásticos (exceto PET) & 290.000 & $20 \%$ \\
PET & 174.000 & $47 \%$ \\
Alumínio (embalagens) & 127.600 & $96,2 \%$ \\
Aço (embalagens) & 160.000 & $29 \%$ \\
Vidro (embalagens) & 390.000 & $46 \%$ \\
Longa Vida & 40.000 & $23 \%$ \\
Pneus & 127.000 & $58 \%$ \\
Orgânicos (compostagem) & 843.150 & $3 \%$ \\
\hline
\end{tabular}

Fonte: CEMPRE 2007

\subsection{1 - OBJETIVOS ESTRATÉGICOS DA LOGÍSTICA REVERSA}

A logística reversa agrega valor de alguma natureza às empresas, seja pelo retorno de bens ao ciclo de negócios ou ao ciclo produtivo. Entretanto, o objetivo estratégico econômico não é único da logística reversa; dois novos fatores incentivam as decisões empresariais em adotá-la: o fator competitividade e o fator ecológico.

Vantagens competitivas podem ser alcançadas quando a empresa oferece um serviço diferenciado ao cliente. Por exemplo, algumas redes varejistas possuem centros de distribuição reversos para dar suporte ao crescimento de devolução e troca dos produtos, satisfazendo as exigências dos seus clientes. Os varejistas acreditam que os clientes valorizam as empresas que possuem políticas mais liberais de retorno de produtos. Esta é uma vantagem percebida, na qual os varejistas ou fornecedores assumem os riscos pela existência de produtos danificados, e é uma tendência que se reforça pela existência de legislação de defesa dos consumidores, garantindo-lhes o direito de devolução e troca (LACERDA, 2002). 
A questão ambiental também é um importante incentivo da logística reversa. Não faz sentido pensar em processos de produção e consumo sem considerar os impactos que estes produzem no meio ambiente. Entre estes problemas estão os resíduos da produção, o lixo gerado pela população, que cada vez mais é composto por restos de embalagens e de produtos industrializados (BARBIERI \& DIAS, 2002).

$\mathrm{O}$ aumento da consciência ambiental dos consumidores e as tendências legislativas ambientais tornam as empresas cada vez mais responsáveis por todo o ciclo de vida do seu produto, incentivando o desenvolvimento da logística reversa e, portanto, contribuindo para a sustentabilidade dos recursos, permitindo que mais bens e serviços sejam produzidos sem degradar a natureza.

A tabela abaixo mostra alguns dos objetivos estratégicos da logística reversa segundo pesquisa realizada nos Estados Unidos:

Tabela 2.2. Motivos estratégicos para as empresas operarem os canais reversos

\begin{tabular}{cc}
\hline Motivo estratégico & Porcentagem de empresas respondentes \\
\hline Aumento de competitividade & $65,2 \%$ \\
Limpeza de canal - estoques & $33,4 \%$ \\
Respeito às legislações & $28,9 \%$ \\
Revalorização econômica & $27,5 \%$ \\
Recuperação de ativos & $26,5 \%$ \\
\hline
\end{tabular}

Fonte: Rogers e Tibben-Lembke (1999, p. 18 apud LEITE, 2003, p. 24) (Adaptado).

Leite (2002) apresenta um modelo de relacionamento que resume a relação de dependência entre diversos fatores e os níveis de organização e dinamismo dos canais de distribuição reversos. Esse modelo é apresentado na Figura 2.5.

\footnotetext{
Rogers, D. S.; Tibben-Lembke, R. S. (1998). Going Backwards: Reverse Logistics Trends and Practices. Universidade of Nevada, Reno. Disponível em: <http://www.rlec.org/reverse.pdf> Acesso em 12 de junho de 2006.
} 


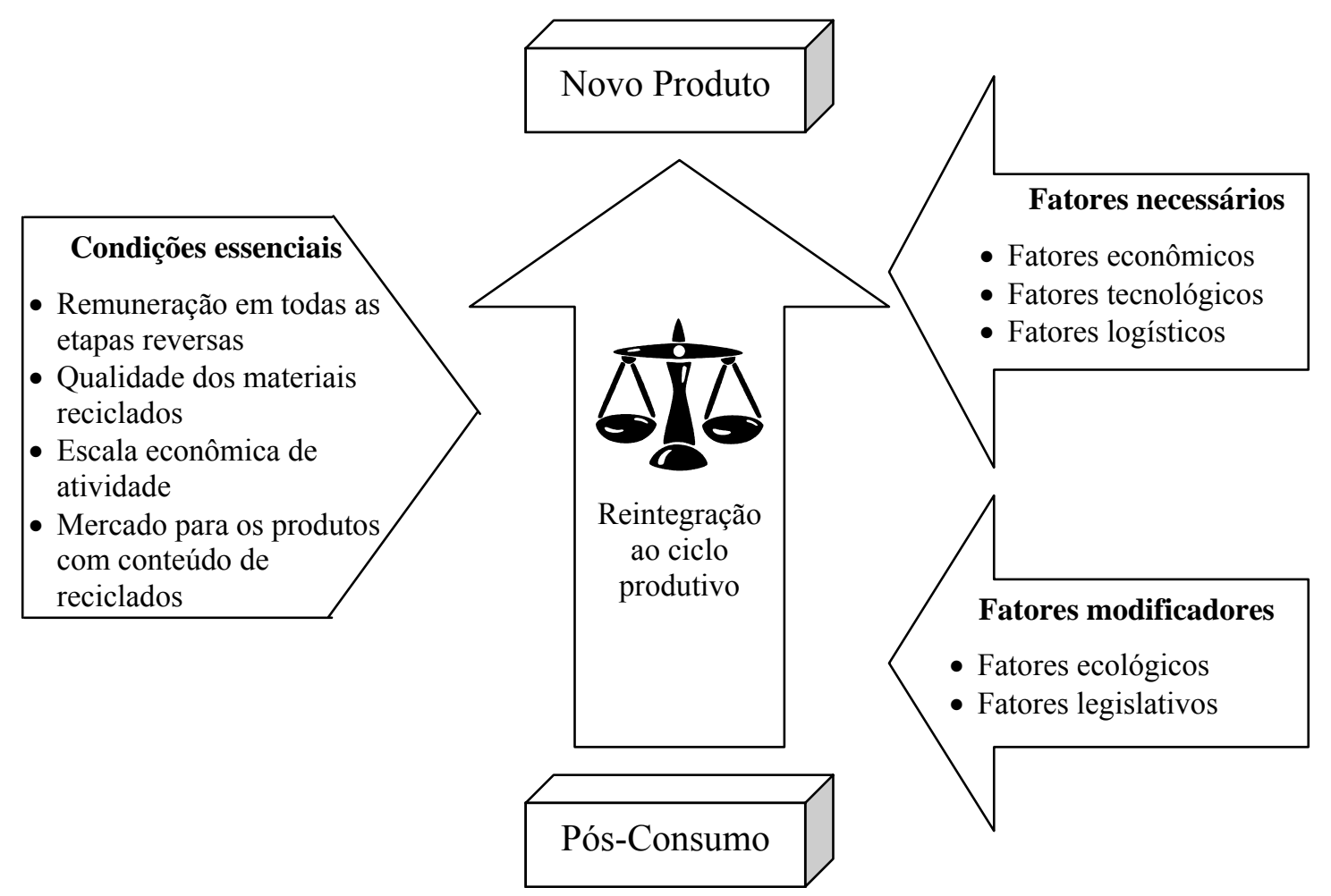

Figura 2.5: Modelo relacional entre os fatores Fonte: Leite, 2002.

“As condições 'essenciais de existência' de fluxos reversos, ou seja, que garantem interesses empresariais satisfatórios e conseqüentes níveis de organização nas cadeias reversas, são denominadas 'fatores necessários'. Por outro lado, denomina-se 'fatores modificadores' de organização e estruturação dos canais de distribuição reversos aqueles que alteram as condições 'naturais' de mercado, nas diversas etapas reversas, permitindo que novas condições de equilíbrio sejam estabelecidas." (Leite, p.91, 2002).

\subsection{2 - FATORES CRÍTICOS QUE INFLUENCIAM A EFICIÊNCIA DO PROCESSO DE LOGÍSTICA REVERSA}

A eficiência do processo de logística reversa vai depender do seu planejamento e controle. Lacerda (2002) identificou seis fatores considerados críticos que, quando bem 
administrados, contribuem positivamente para o desempenho do sistema logístico reverso. Os fatores críticos são:

- Bons controles de entradas;

- Processos mapeados e formalizados;

- Ciclo de tempo reduzido;

- Sistemas de informação acurados;

- Rede logística planejada;

- Relações colaborativas entre clientes e fornecedores. 


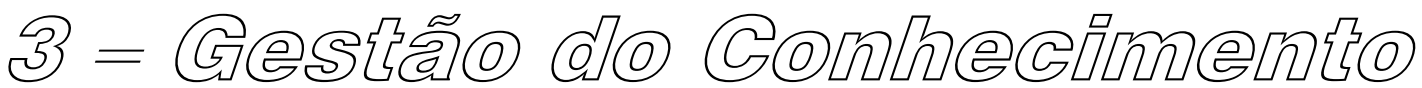

Desde o princípio da década de 1990, a gestão do conhecimento ganhou maior visibilidade como fonte de vantagem competitiva e como meio de construir um ambiente fecundo ao aprendizado, capaz de atender às demandas da economia pósindustrial da informação.

Para Stewart (1998, apud Perrotti, p. 3) o conhecimento tornou-se um recurso econômico proeminente e, a informação e o conhecimento são mais importantes que qualquer outro produto da era industrial.

De acordo com Sveiby (1997, apud Perrotti, p. 6), a economia da era do conhecimento oferece recursos ilimitados e para Stewart (2001, apud Perrotti, p. 6) prosperar nessa nova economia requer um novo vocabulário, novas técnicas de gerenciamento, novas tecnologias e novas estratégias.

O conhecimento, apontado como um recurso organizacional crítico, vem se convertendo em valiosa fonte de vantagem competitiva, razão pela qual as empresas mais agressivas vêm esforçando-se para converter o conhecimento acumulado em cada empresa em um patrimônio corporativo (SANTOS, 2004).

Stewart, Thomas A. The Wealth of Knowledge. New York: Currency, 2001

Stewart, Thomas A. Capital Intelectual. Rio de Janeiro: Campus, 1998

Sveiby, Karl E. The New Organizational Wealth: Managing and Measuring knowledge-based assets. São Francisco: Berreth-Koehler Publishers, 1997. 
Segundo Davenport e Prusak (1998, apud Ledel, p. 5):

"o conhecimento é uma mistura fluida de experiências, valores, informações contextualizadas, e "insights" de especialistas, que provê uma estrutura para avaliar e incorporar novas experiências e informações. Ele se origina e é aplicado na mente de conhecedores. Em organizações, ele está incorporado não apenas em documentos e repositórios mas também em rotinas organizacionais, processos, práticas e normas".

O conhecimento é criado através da interação entre as formas de conhecimento tácita e explícita. Os modos de conversão do conhecimento decorrentes desta classificação são: (1) de tácito para tácito, chamado de socialização; (2) de tácito para explícito, chamado de externalização; (3) de explícito para explícito, chamado de combinação; e (4) de explícito para tácito, conhecido como internalização (NONAKA E TAKEUCHI, 1997).

Conhecimento explícito é aquele que se manifesta em orações, frases, pode ser colocado no papel ou expresso por desenho, já o conhecimento tácito se vincula aos sentidos, à percepção individual, às experiências físicas, às regras práticas e à intuição, ou seja, é muito difícil descrever esse tipo de conhecimento.

A criação do conhecimento organizacional proposto por Nonaka e Takeuchi (1997) está fortemente vinculada ao processo individual de auto-renovação organizacional e pessoal.

Davenport, T. H.; PRUSAK, Laurence.(1998) Conhecimento empresarial:como as organizações gerenciam seu capital intelectual,métodos e aplicações práticas. Rio de Janeiro: Campus. 
É necessário um compromisso pessoal dos funcionários, pois sua identificação com a empresa e sua missão torna-se indispensável. Há o envolvimento tanto de ideais como de idéias. Estes ideais e idéias são os ingredientes para a inovação. Defendem que criar novos conhecimentos é recriar a empresa e todos dentro dela. Esta criação de novos conhecimentos é responsabilidade de toda a organização.

Para isto apresentam algumas características chave para a criação do conhecimento:

- Metáfora e analogia: é uma forma de fazer com que indivíduos fundamentados em contextos diferentes e com diferentes experiências compreendam algo intuitivamente pelo uso da imaginação e dos símbolos. Através das metáforas, as pessoas reúnem o que conhecem de novas formas e começam a expressar o que sabem, mas que ainda não são capazes de dizer. A metáfora é eficaz na promoção do processo criativo. Já a analogia esclarece as semelhanças e diferenças entre duas idéias ou objetos. É um degrau intermediário entre a imaginação pura e pensamento lógico.

- Do conhecimento pessoal ao conhecimento organizacional: a organização pode criar conhecimento por si mesma sem a iniciativa do indivíduo e a interação que ocorre dentro do grupo. O conhecimento pode ser amplificado ou cristalizado em nível de grupo, por meio de discussões, compartilhamento de experiências e observação.

- Ambigüidade e redundância: a ambigüidade pode vir a ser útil algumas vezes não apenas como fonte de um novo senso de direção, mas também como fonte de significados novos e de uma forma diferente de pensar. 
Nesse sentido, o novo conhecimento nasce do caos. A redundância é importante porque estimula o diálogo freqüente e a comunicação. Isso ajuda a criar uma "base cognitiva comum" entre os funcionários, facilitando assim a transferência do conhecimento tácito.

A criação dinâmica do conhecimento está ancorada no conhecimento humano que é criado e expandido pela interação social entre o conhecimento tácito e o conhecimento explícito (NONAKA E TAKEUCHI, 1997).

Neste sentido, como foi citado anteriormente, os autores apresentam quatro modos de conversão do conhecimento:

1. De conhecimento tácito em conhecimento tácito: socialização. Tem uma ligação com as teorias dos processos de grupo e da cultura organizacional;

2. De conhecimento tácito em conhecimento explícito: externalização. Esta foi negligenciada na teoria organizacional;

3. De conhecimento explícito em conhecimento explícito: combinação. Tem suas raízes no processamento de informações;

4. De conhecimento explícito em conhecimento tácito: internalização. Está intimamente relacionada com o aprendizado organizacional.

Assim, estes autores apresentaram um modelo, chamado de Espiral do Conhecimento, que explica a dinâmica da conversão entre as formas do conhecimento (tácito e explícito) no contexto de uma organização, através da interação social entre os indivíduos. Este modelo está representado na Figura 3.1. 


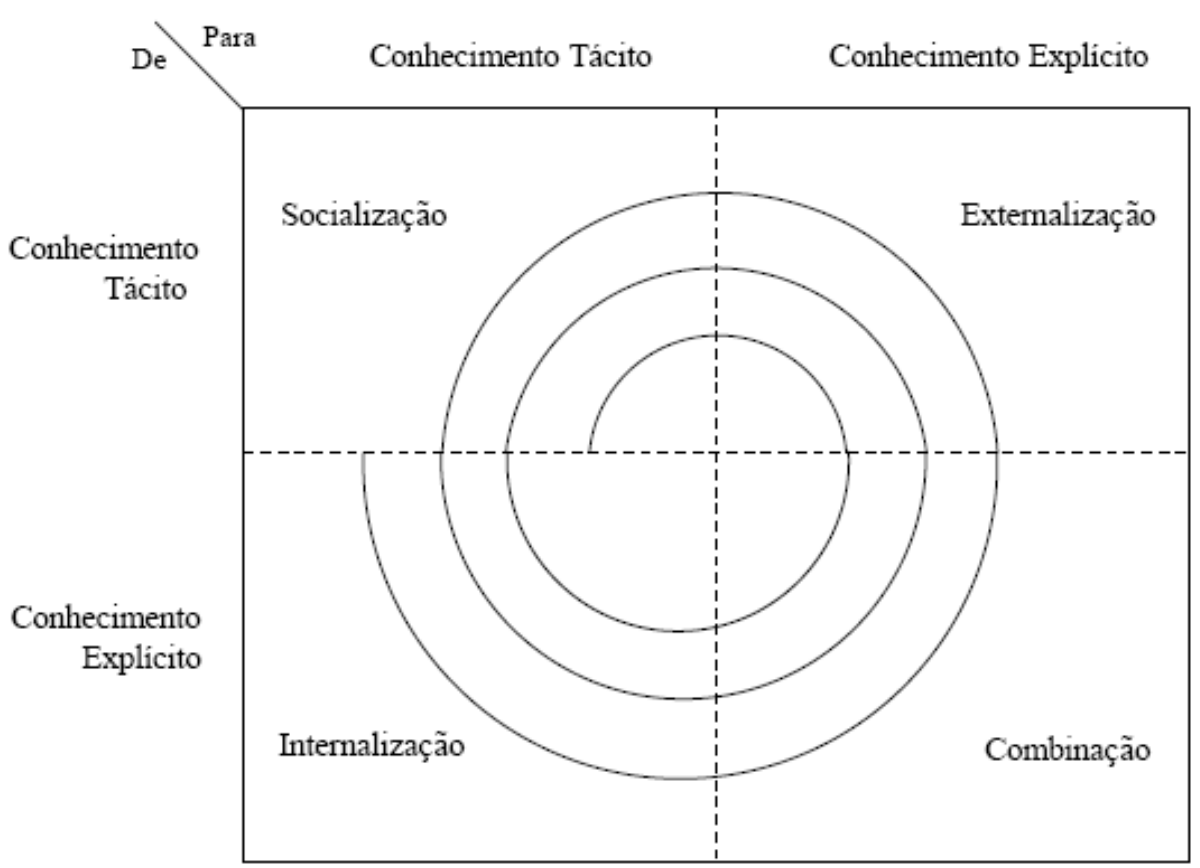

Figura 3.1: Modelo em espiral do conhecimento Nonaka e Takeuchi (1997)

Ainda, segundo Nonaka e Takeuchi (1997), esta espiral do conhecimento opera da seguinte forma: (1) primeiramente o conhecimento é convertido de tácito para tácito, através da socialização; (2) em seguida, este conhecimento tácito é convertido em explícito, através da externalização; (3) o conhecimento explícito mescla-se com o explícito já existente, através da combinação; e (4) o conhecimento explícito é convertido em tácito, através da internalização. Este movimento em espiral, que tem o sentido horário, prossegue em ciclos de maior amplitude, durante todo o período de desenvolvimento de um produto ou conceito em uma organização.

De acordo com Ledel (2005), uma vez identificado o valor do conhecimento nas empresas, começou-se a pensar em formas de gerenciá-lo. Ainda nos anos 90, empresas norte-americanas, européias e japonesas começaram a desenvolver estratégias de gerenciamento do conhecimento "para se criar novo conhecimento, difundi-lo na organização como um todo e incorporá-lo a produtos, serviços e sistemas" (NONAKA E TAKEUCHI, 1997, p. 01). 
Nonaka e Takeuchi (1997) organizaram suas idéias acerca de criação do conhecimento nas empresas, a partir de um estudo com empresas inovadoras e bemsucedidas do Japão e dos Estados Unidos, publicado em 1995. Neste estudo, eles associam o desempenho das empresas à sua capacidade de gerar novos conhecimentos e usá-los no desenvolvimento de produtos e tecnologias.

De forma semelhante, Davenport e Prusak (1998 apud Ledel, 2005, p. 20) estudaram os processos organizacionais que possibilitam a geração de conhecimentos, sua codificação, e a sua transferência. A estes autores credita-se a primeira utilização do termo gerenciamento do conhecimento que, segundo os autores, “é o nome dado ao conjunto de ações sistemáticas e disciplinadas que uma organização pode tomar, a fim de obter o melhor valor do conhecimento que lhe está disponível".

O gerenciamento do conhecimento trata da armazenagem, organização e distribuição do conhecimento possuído por uma empresa ou organização.

O gerenciamento do conhecimento, segundo Ledel (2005), abrange, portanto, ações de identificação e mapeamento do capital intelectual dentro de uma organização, a geração de novos conhecimentos e o compartilhamento de melhores práticas, com o intuito de aprimorar os seus produtos e, consequentemente, trazer uma vantagem competitiva à mesma.

O gerenciamento do conhecimento tem como objetivos gerais o crescimento, a comunicação, e a preservação do conhecimento em uma organização (Steels 1993 apud Ledel, 2005, p. 20). Davenport e Prusak (1998 apud Ledel, 2005, p. 21) referem-se ao

\footnotetext{
Davenport, T. H.; PRUSAK, Laurence.(1998) Conhecimento empresarial:como as organizações gerenciam seu capital intelectual,métodos e aplicações práticas. Rio de Janeiro: Campus.

Steels, L. (1993). Corporate Knowledge Management, ISMICK'93, Compi'egne,France, pp. 9-30.

Ledel, L. C. Gerenciamento do Conhecimento Aplicado a Fins Educacionais. Campinas - SP. 2005.
} 
objetivo de a organização obter o melhor valor do conhecimento que lhe está disponível, a fim de alcançar uma vantagem competitiva no mercado em que atua.

Boury-Brisset (1999 apud Ledel, 2005, p. 21) aponta para quatro objetivos de gerenciamento do conhecimento inter-relacionados: (1) tornar permanentes todas as formas de conhecimento de uma organização; (2) tornar os conhecimentos disponíveis aos utilizadores potenciais, que podem estar distribuídos geograficamente; (3) tornar explícitos os conhecimentos que são mais pertinentes ao funcionamento da organização e (4) permitir uma melhor eficácia do trabalho. Já Davenport e Prusak (1998), referemse ao objetivo da organização obter o melhor valor do conhecimento que lhe está disponível, a fim de alcançar uma vantagem competitiva no mercado em que atua.

\section{1 - MODELOS DE GESTÃO DO CONHECIMENTO}

Santos (2004) comentou que, apesar do esforço dos pesquisadores em formular modelos de gestão de conhecimento, é imprescindível destacar que a sobrevivência de qualquer modelo voltado ao conhecimento estará baseada sempre na efetividade com que este apóie as estratégias do negócio, gerando vantagens competitivas sustentáveis, ou ainda, permitindo que as organizações possuam mecanismos que garantam, aos acionistas, a perpetuidade do negócio, melhorando continuamente a sua atratividade.

Albrecht (2004 apud Santos, 2004, p. 61) afirma que "a forma mais segura de inibir o desenvolvimento de fenômenos é tentar gerenciá-los", recomendando que, ao

Davenport, T. H.; Prusak, Laurence.(1998) Conhecimento empresarial:como as organizações gerenciam seu capital intelectual,métodos e aplicações práticas. Rio de Janeiro: Campus.

Boury-Brisset, A.-C. (1999). Gestion des connaissances d'une m'emoire corporative construite autour d'ontologies, IC'99, Val-B'elair,Canada, pp. 181-188.

Albrecht, K. Um modelo de inteligência organizacional. HSM Management. Barueri - SP, v. 3, n.44, p.30-34, mai-jun. 2004. 
contrário da gestão do conhecimento, o que implicaria estabelecer algum tipo de ordem limitante, o mais viável seria gerenciar as culturas de conhecimento, criando assim bases para a geração de conhecimentos que possam prosperar e que possam resultar, a partir da formação da inteligência organizacional, em sucesso empresarial.

Assim surgem alguns modelos de gestão do conhecimento que serão, brevemente, descritos nesse trabalho.

\subsection{1 - MODELO DE NONAKA E TAKEUCHI}

Santos (2004) afirma que Nonaka e Takeuchi verificaram que a visão da organização como uma processadora de informações do ambiente externo, visando sua adaptação, era insuficiente para explicar o fenômeno da criação do conhecimento organizacional e da inovação. Para compreender esse processo, os autores adotam uma tipologia do conhecimento orientada para duas dimensões apresentadas na Figura 3.2:

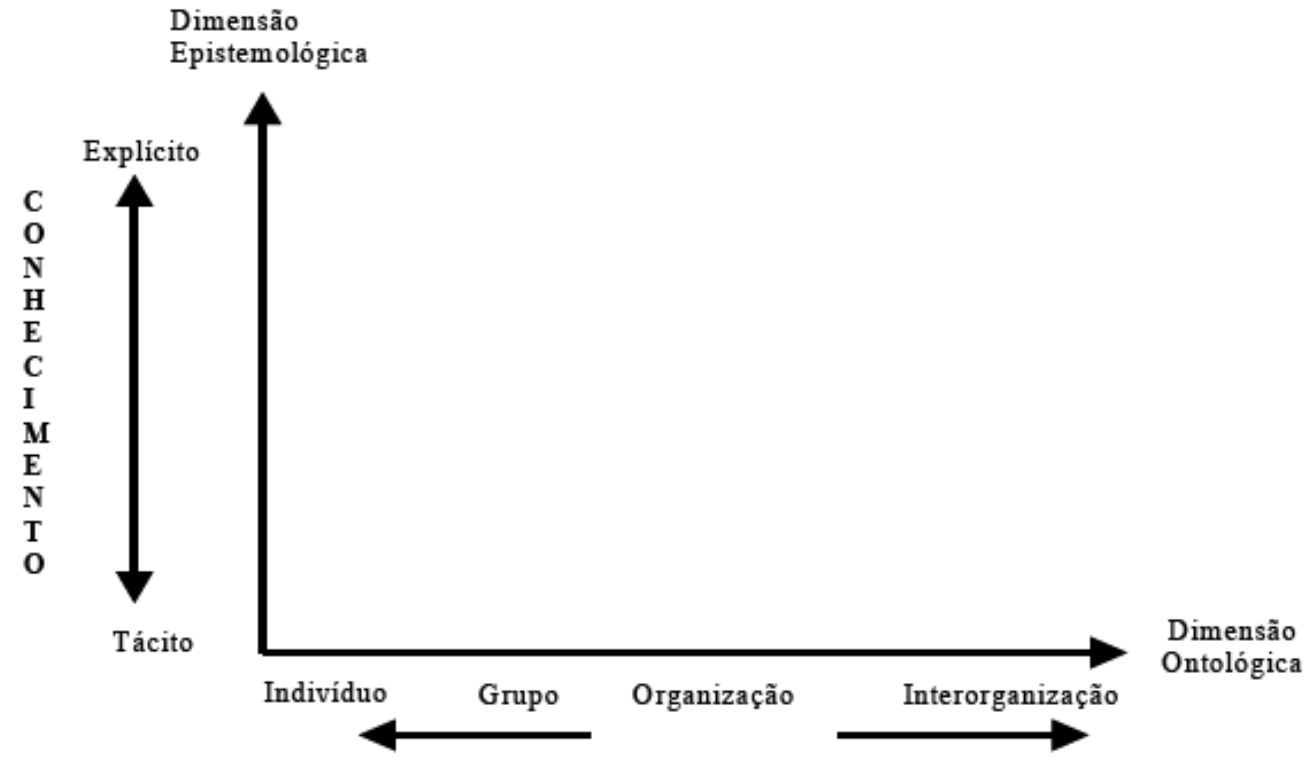

Niveis do Conhecimento

Figura 3.2: Duas Dimensões da Criação do Conhecimento (Nonaka e Takeuchi, 1997) 
Segundo os autores, a criação do conhecimento está na mobilização e conversão do conhecimento tácito para explícito, o que ocorreria entre as duas dimensões:

I. A epistemológica, que trata da teoria do conhecimento que separa o sujeito do objeto e da percepção;

II. A ontológica, que trata das entidades criadoras do conhecimento, a partir do indivíduo, já que a organização não pode criar conhecimento sem indivíduos, e a criação do conhecimento organizacional deve ser vista como uma ampliação do conhecimento dos indivíduos.

A conversão do conhecimento tácito, definida pelos autores como "motor" do processo de criação do conhecimento, dar-se-ia a partir dos seguintes processos:

a) Socialização, que trata do compartilhamento de experiências;

b) Externalização, formação de conceitos explícitos, a partir do conhecimento tácito;

c) Combinação, que é a sistematização dos conceitos em um sistema de conhecimento;

d) Internalização, que se refere à incorporação do conhecimento explícito no tácito, sob as formas de novos modelos mentais ou conhecimento técnico compartilhado. A interação dos processos de conversão, na definição deles próprios, ocorre na forma de uma espiral do conhecimento.

Segundo Nonaka e Takeuchi (1997, p. 83-94), a espiral do conhecimento é decorrente das seguintes pré-condições organizacionais: 
a) a intenção da organização em atingir suas metas estabelecidas, a concessão de autonomia para a motivação a novos conhecimentos e tomada de risco, também apontado por Morin (1996, p. 96);

b) a flutuação e caos criativo que estimulam a interação da organização com o ambiente externo, que permita a ordem a partir do caos, ou o princípio de "ordem e desordem e auto-organização" de Morin (1990, p. 88-96);

c) a redundância que se refere à existência de informações além das exigências operacionais imediatas dos membros da organização; e,

d) a variedade de requisitos que corresponde à compatibilidade da diversidade interna da organização aos requisitos e à complexidade do ambiente externo.

Nonaka e Takeuchi (1997, p. 64) vêem a criação do conhecimento como um processo interativo entre o racional e o empírico, entre a mente e o corpo, entre a análise e a experiência e entre o implícito e o explícito. Estes autores acreditam que o conhecimento tácito envolve duas dimensões: uma técnica, do tipo know-how, e outra cognitiva, que envolve modelos mentais, crenças e percepções. Dessa maneira, a noção de conhecimento deles confere grande ênfase aos "insights", intuições, ideais, valores, emoções, imagens e símbolos.

Com relação ao processo de criação do conhecimento, os autores definem cinco fases. A primeira fase refere-se ao compartilhamento do conhecimento tácito entre os indivíduos. A segunda fase refere-se à criação de conceitos. A terceira fase é a justificação dos conceitos como uma crença verdadeira. A quarta fase diz respeito à 
construção de um arquétipo. E a quinta fase refere-se à difusão interativa do conhecimento.

\subsection{2 - MODELO DE CHAI}

De modo análogo, Chai (2000 apud Santos, 2004, p. 65), referindo-se à área de tecnologia, adiciona o conhecimento de processo, como direitos de patente, detalhes de projetos de engenharia e outros, e conhecimento de pessoas, que envolve habilidades de relacionamento, percepções do ambiente e outros. Esses conhecimentos inserem-se dentro da tipologia de Nonaka e Takeuchi (1997), ou seja, tácito e explícito, na qual Chai acrescenta mais um tipo de conhecimento contextualizado, ao qual denomina de conhecimento local. Chai concluiu que existe um mecanismo de transferência apropriado à natureza de cada tipo de conhecimento.

Segundo Santos (2004) ao elenco de tipos de conhecimento que vem sendo utilizado pelos autores mais recentes, deve ser considerado um quarto tipo particular de conhecimento, o conhecimento sensível. Esse tipo de conhecimento ocorre na aplicação dos sentidos e "é um modo exemplar do conhecer, ao menos por sua precocidade e por sua universalidade" (SANTOS, 2004). O conhecimento sensível é intransferível na sua totalidade, senão através de metáforas. Somando-se a contribuição dos diferentes autores resultaria na seguinte tipologia do conhecimento:

Chai, Kah-Him. Kowlegde sharing and reuse international manufacturing networks: an exploratory study. Institute for Manufacturing Engineering, University of Cambridge. Sep. 2000. 


\begin{tabular}{|c|c|c|}
\hline Tipo de conhecimento & Descrição & $\begin{array}{l}\text { Mecanismo de } \\
\text { Transferência } \\
\end{array}$ \\
\hline $\begin{array}{l}\text { Conhecimento Explícito } \\
\text { ou Codificado }\end{array}$ & $\begin{array}{l}\text { Esse conhecimento quando é articulado é pouco } \\
\text { dependente do contexto, tendo como exemplos } \\
\text { procedimentos simples de operação, desenhos } \\
\text { técnicos e outros. }\end{array}$ & $\begin{array}{l}\text { Relatórios, revistas, } \\
\text { jornais, procedimento- } \\
\text { padrão de operação. }\end{array}$ \\
\hline $\begin{array}{c}\text { Conhecimento Tácito ou } \\
\text { Experimental }\end{array}$ & $\begin{array}{l}\text { Forma de conhecimento altamente tácita, porém, } \\
\text { com pouca dependência contextual, como } \\
\text { problemas envolvendo perícias e truques do } \\
\text { negócio. }\end{array}$ & $\begin{array}{l}\text { Expatriação, treinamento } \\
\text { em outros lugares. }\end{array}$ \\
\hline Conhecimento Local & $\begin{array}{l}\text { É normalmente articulado, porém muito } \\
\text { dependente do contexto, quando este tipo de } \\
\text { conhecimento é transferido, interpretações } \\
\text { errôneas podem ocorrer em partes menos óbvias } \\
\text { do conhecimento. Um exemplo seria um } \\
\text { procedimento padrão de operação que só pode } \\
\text { ser feito em ocasiões muito específicas. }\end{array}$ & $\begin{array}{l}\text { Melhores práticas, } \\
\text { periódicos, } \\
\text { benchmarking, fóruns, } \\
\text { times internacionais. }\end{array}$ \\
\hline Conhecimento Sensível & $\begin{array}{l}\text { Conhecimento apreendido por meio dos cinco } \\
\text { sentidos. Possui grande interferência do meio e } \\
\text { dependência do objeto, através do qual } \\
\text { reconhece e codifica o fenômeno. }\end{array}$ & $\begin{array}{l}\text { Contato direto com o } \\
\text { objeto. Não } \\
\text { transferível, senão por } \\
\text { metáforas. }\end{array}$ \\
\hline
\end{tabular}

Tab. 3.1: Tipologia do Conhecimento Revisada.

Fonte: retirada de Santos (2004)

Quanto ao processo de transferência, Chai (2000), em sua pesquisa exploratória sobre empresas de manufatura, analisa que ele ocorra em uma seqüência de quatro passos: a) percepção da relevância da informação; b) transferência ou compartilhamento da informação e compreensão do contexto entre fornecedor e recebedor da informação; c) adaptação ou recriação do conhecimento; e, d) integração ou introjeção do conhecimento a tal ponto que ele já não seja mais novidade ao seu recebedor. No caso do conhecimento tácito, essa fase corresponde à formulação de rotinas, no padrão "do jeito que fazemos aqui".

\subsection{3 - MODELO DE DAVENPORT E PRUSAK}

Davenport e Prusak (1998, p. 107-128) valorizam a transferência espontânea e não estruturada do conhecimento, concluindo que esse processo pode definir o sucesso ou fracasso de uma organização. Contudo, a expressão gestão ou gerenciamento do 
conhecimento pressupõe um processo lógico-formal de transferência. Os autores recomendam o desenvolvimento de estratégias específicas que fomentem as trocas espontâneas de conhecimento. Eles apontam algumas táticas bem-sucedidas, tais como:

a) Criação de áreas de convívio dentro da organização, por exemplo, as cafeterias;

b) Atividades compartilhadas de lazer, como as happy-hours;

c) Sistematização das informações através da rede de computadores;

d) Feiras e fóruns abertos do conhecimento;

e) Sistemas de vídeo-conferência;

f) Registro eletrônico de informações disponíveis com os empregados mais antigos;

g) Criação de programas de monitoração e treinamento;

h) Observação de demonstração prática do trabalho, isso, em particular quando a aprendizagem puder contribuir para a destreza e melhoria do relacionamento;

i) Convivência em projetos e estágios;

j) Bancos de dados para conhecimento compartilhado, e outros mecanismos.

É importante destacar que, na compreensão de Davenport e Prusak (1998, p. 117) "quanto mais rico e tácito for o conhecimento, mais tecnologia deverá ser usada para possibilitar às pessoas compartilhar aquele conhecimento diretamente". Contudo, a infra-estrutura de transferência do conhecimento tácito não deve se limitar à tecnologia eletrônica. Os autores ainda destacam obstáculos básicos ao compartilhamento de conhecimento: dotar a comunidade de uma linguagem comum e acessível a todos, sem a qual não haverá, minimamente, um contato pessoal produtivo. Outro obstáculo que vale a pena ser mencionado é a falta de confiança mútua entre os membros dos grupos de conhecimento. 


\subsection{4 - MODELO DE ALBRECHT}

Albrecht (2004 apud Santos, 2004, p. 73) propõe um modelo de inteligência organizacional que tem como pressuposto a identificação de gap de inteligência, partindo do princípio que apenas um número relativamente pequeno de profissionais, altamente qualificados, está preparado para trabalhar o conhecimento e, com isso, exercer as funções de gestão efetiva do negócio, como planejar, projetar, organizar, liderar, gerir, analisar, decidir, inovar e ensinar. A perda da energia resultante dessa pequena, porém significativa, massa de profissionais, seria vital para o cumprimento da missão organizacional, que o autor define como o "imposto da entropia". O modelo proposto por Albrecht contém sete dimensões-chave:

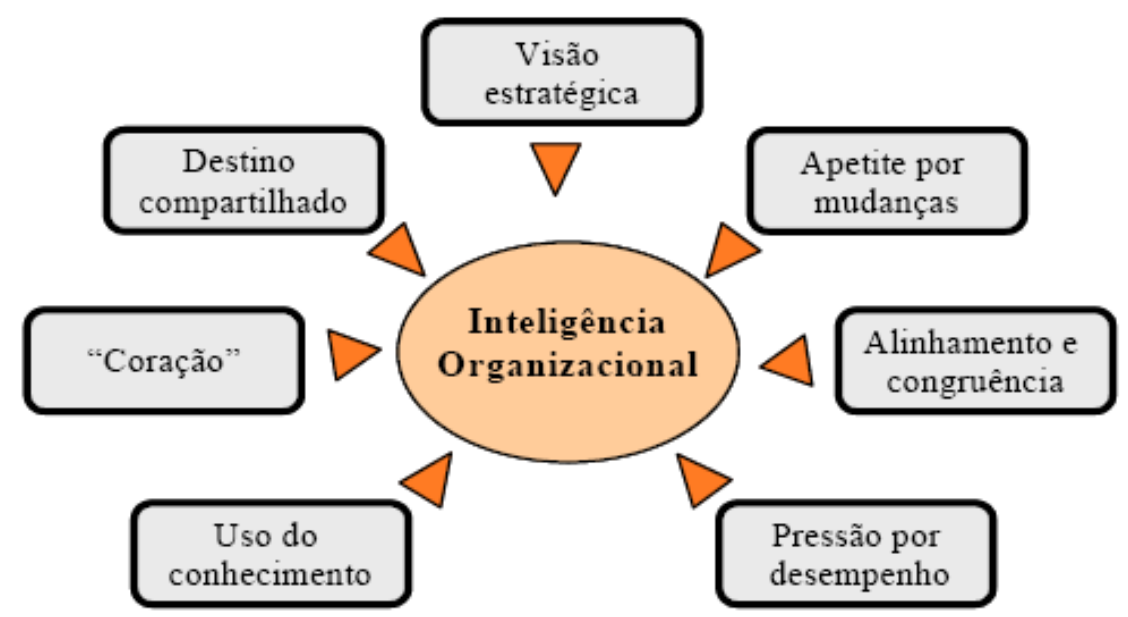

Fig. 3.3: Modelo de Inteligência Organizacional

Fonte: Albrecht, 2004 retirado de Santos (2004)

Albrecht, K. Um modelo de inteligência organizacional. HSM Management. Barueri - SP, v. 3, n.44, p.30-34, mai-jun. 2004. 
De acordo com Santos (2004), cada dimensão pode ser compreendida através do seguinte conjunto de significados:

a) Visão estratégica: capacidade para criar, desenvolver e implementar um conceito de finalidade, de direcionamento e de destino;

b) Destino compartilhado: assemelha-se à definição de objetivo comum proposta por Senge (1990), ou seja, estabelecer um sentido de conexão por meio de uma finalidade comum;

c) Apetite por mudanças: equivale à ruptura com paradigmas e modelos mentais pré-concebidos, possibilitando a criação de pré-condições e de novas formas de conceber a realização e o sucesso da empresa;

d) "Coração": entusiasmo para aplicar um nível de energia extra para que a empresa obtenha sucesso;

e) Alinhamento e Congruência: corresponde à disponibilidade infra-estrutural necessária para que a organização atinja sua visão estratégica;

f) Uso do conhecimento: capacidade da organização em fomentar, desenvolver e aplicar novos conhecimentos e a sabedoria disponível internamente;

g) Pressão por desempenho: que pode ser definida como engajamento pessoal com que cada empregado se mobiliza, e contagia os demais, visando atingir os resultados propostos. 
O modelo de Albrecht (2004) contempla dimensões humanas da gestão, não apenas do conhecimento, mas sim da formação do pensamento organizacional que capacita os recursos, de modo crítico e determinado, rumo ao sucesso, segundo o autor.

Ainda, de acordo com Santos (2004), a questão da geração de competências dinâmicas e o desenvolvimento da capacidade de responder rapidamente aos desafios do ambiente, interno e externo, passam necessariamente pela análise de como o ambiente interno é orientado para envolver os seus recursos humanos em ações empreendedoras, como a liderança pode, através do compartilhamento de responsabilidades e da autonomia, derrubar as cercas emocionais que dividem quem pode ou não ser criativo e inovador e, em decorrência dos valores que o estilo de gestão promove, como transformar a cultura organizacional, na velocidade imposta pelas inovações externas, em bases, efetivamente, inovadores e empreendedoras.

Com a revisão bibliográfica finalizada, o trabalho mostra no próximo capítulo os programas estudados, dando ênfase aos aspectos estudados até o momento. 


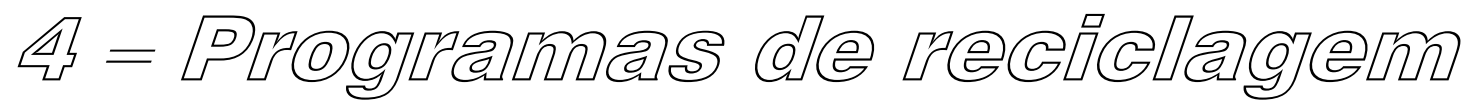

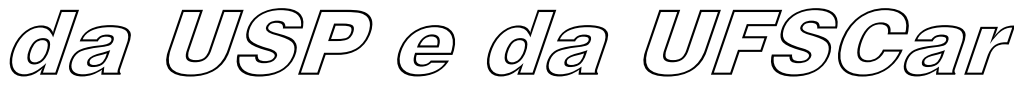

\section{1 - PROGRAMA DE RECICLAGEM DA UNIVERSIDADE DE SÃO PAULO - USP RECICLA}

\subsection{1 - Informações Gerais sobre o Programa USP Recicla}

De acordo com USP Recicla ${ }^{(}$(2003), O "USP Recicla - da Pedagogia à Tecnologia" é um programa permanente da USP, desenvolvido por suas unidades e órgãos em parceria com a Coordenadoria Executiva de Cooperação Universitária e de Atividades Especiais (CECAE/USP), um órgão da Reitoria da USP, a qual tem a função de articular e facilitar sua implantação e promoção e que agora se chama Agência USP de Inovação.

Por meio de iniciativas educativas, informativas e de gestão integrada de resíduos, o Programa USP Recicla busca transformar a USP em um bom exemplo de consumo responsável e de destinação adequada dos resíduos. (USP Recicla ${ }^{\circledR}, 2003$ )

O Programa foca suas atividades na Comunidade USP (estudantes, professores, pesquisadores, funcionários e visitantes), que é composta por aproximadamente 85.000 pessoas, das quais cerca de 15.000 se renovam a cada ano e está presente nos seis campi

\footnotetext{
${ }^{1}$ Fonte: Dados e informações retirados em:
} 
PROGRAMA USP RECICLA (2003). Universidade de São Paulo. Desenvolvido pela Agência USP de Inovação. Disponível em: $<\mathrm{http}: / /$ www.cecae.usp.br/recicla/site> .Acesso em 09 de outubro de 2006 da USP (Bauru, Piracicaba, Pirassununga, Ribeirão Preto, São Carlos e São Paulo). Segundo USP Recicla ${ }^{\odot}$ (2003), conta com a atuação direta de aproximadamente 500 pessoas entre docentes, funcionários e alunos.

"Partindo da noção de redes sociais, o USP Recicla possui uma estrutura organizativa cuja base são as comissões de unidades ou órgãos”. (USP Recicla ${ }^{\circledR}, 2003$ )

O USP Recicla é financiado principalmente por verbas do orçamento da USP. A venda de papel e papelão recolhidos, coletados seletivamente na universidade, também gera uma pequena receita em São Paulo, Piracicaba e São Carlos, contudo, muito inferior às despesas gerais do Programa. (USP Recicla ${ }^{\circledR}, 2003$ )

\subsection{2 - O Surgimento do Programa}

Da mesma forma que no ensino, pesquisa e extensão, a USP pode e deve buscar excelência na gestão do consumo de materiais e na destinação de resíduos. Considerando o potencial de difusão e aperfeiçoamento de idéias, conceitos e propostas, torna-se recomendável que a universidade, por meio de suas diversas unidades, adote bons exemplos de práticas ambientalmente adequadas. Partindo deste entendimento, o USP Recicla foi institucionalizado em 1994 sob coordenação da CECAE. (USP Recicla $\left.^{\circledR}, 2003\right)$

\subsection{3 - Objetivos}

A missão do Programa é:

Contribuir para a construção de sociedades sustentáveis, por meio de ações voltadas a minimização de resíduos, conservação do meio ambiente, melhoria da qualidade de vida e formação de pessoas comprometidas com estes ideais. (USP Recicla ${ }^{\circledR}, 2003$ ) 
Assim, suas iniciativas objetivam, de acordo com USP Recicla ${ }^{(\mathcal{O}}$ (2003):

- Estimular a comunidade USP a incorporar valores, atitudes e comportamentos ambientalmente adequados, em especial, a redução na geração de resíduos;

- Colaborar para o estabelecimento de políticas de conservação, recuperação, melhoria do meio ambiente e da qualidade de vida na USP, no seu entorno e interfaces;

- Contribuir para fortalecer as preocupações e os cuidados sócio-ambientais dos estudantes que anualmente se formam na USP;

- Constituir um processo de gestão compartilhada e integrada de resíduos na USP, tornando-o um bom exemplo para a sociedade;

- Apoiar e fomentar a promoção de iniciativas voltadas aos objetivos acima e que articulem aspectos de pesquisa, ensino, extensão e gestão cotidiana da universidade.

\subsection{4 - Histórico da Coleta Seletiva na USP}

A preocupação com a coleta seletiva de todos os materiais descartados na USP sempre fez parte da proposta inicial do programa (1994), mas por representar cerca de $70 \%$ do lixo gerado na universidade, o papel foi o material escolhido para iniciar a coleta na USP.

Em 2005 foi lançado no programa a ampliação da coleta nos campi de São Carlos, Piracicaba e São Paulo, para os demais recicláveis: metais, vidros e plásticos. Já 
nos campi de Bauru, Ribeirão Preto e Pirassununga, a coleta existe desde 1996, impulsionada por programas das prefeituras municipais.

\subsection{5 - O Funcionamento da Coleta Seletiva no Campus da USP São Carlos}

No Campus de São Carlos, os materiais são coletados de forma diferenciada em 2 tipos de coletores:

1) Coleta Seletiva de Papel: sendo o papel o principal resíduo gerado pela universidade, este é depositado em caixas de papelão ou em cestas plásticas como na Figura 4.1. Diariamente é recolhido pela equipe de limpeza contratada pelas unidades em sacos de ráfia (retornáveis), armazenados na própria unidade, até serem transportados a um dos dois galpões do USP Recicla, onde é pesado por cada unidade. Até o ano de 2005, a cada dois meses, o material coletado era vendido para indústrias de reciclagem e a verba revertida para uso do Programa.

Portanto, desde o ano de 2006, os papéis são doados para a Cooperativa de Catadores COOPERVIDA. O total coletado seletivamente e encaminhado para reciclagem pelo campus de São Carlos em 2006 é de $18.138,5 \mathrm{~kg}$.

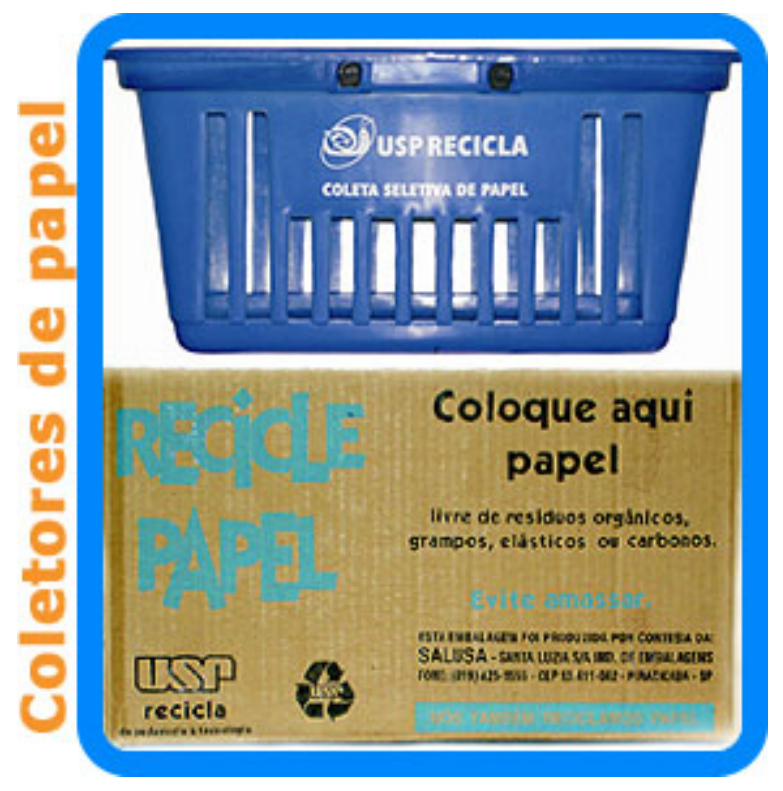


Figura 4.1: Tipos de coletores utilizados para a coleta seletiva de papel na USP. Fonte: USP Recicla ${ }^{C}$ (2003)

Papéis Recicláveis: sulfite, jornal, papelão, revista, papel colorido e papel de presente.

2) Coleta Seletiva de Plásticos, Vidros e Metais: o sistema é semelhante à coleta do papel, porém os recicláveis são separados em um único coletor (de cor laranja), representado na Figura 4.2. Essa opção se deu a partir do resultado de outras experiências e com o intuito de tornar o sistema mais eficiente e otimizado, tanto para quem separa quanto para quem coleta e transporta. Os recicláveis são coletados diariamente em sacos azuis ou transparentes pela equipe de limpeza e levados ao outro galpão, diferente do local onde está armazenado o papel.

Periodicamente o material coletado é doado para a Cooperativa COOPERVIDA. Devido à ausência de uma balança no local, o total coletado é desconhecido. Entretanto, é verificado que os recicláveis são descartados pela comunidade sempre limpos e secos.

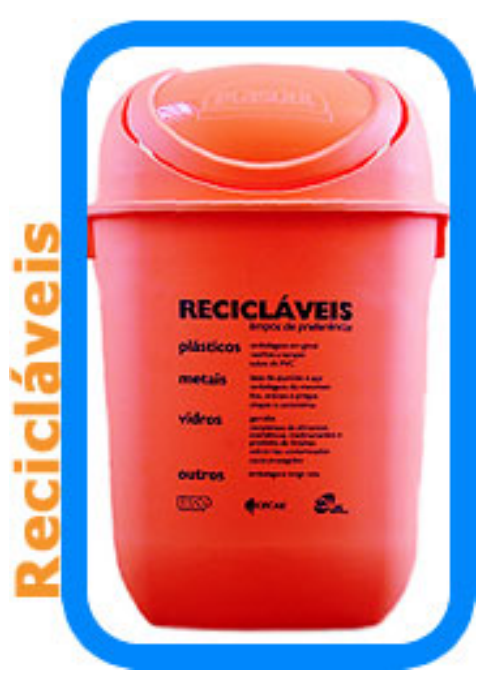

Figura 4.2: Coletor utilizado para a coleta seletiva de plásticos, metais e vidros na USP. Fonte: USP Recicla $\left.{ }^{(}\right)(2003)$ 


\section{Materiais Recicláveis:}

- Plásticos: embalagens em geral, vasilhas e tampas, tubos de PVC;

- Metais: latas de alumínio e aço, embalagens de marmitex, fios, arames e pregos, chapas e cantoneiras;

- Vidros: garrafas, recipientes de alimentos, cosméticos, medicamentos e produtos de limpeza, vidros não contaminados, cacos protegidos;

- Outros: caixas tipo longa vida.

\section{3) Outros Tipos de Coletas:}

Coleta Diferenciada de Lâmpadas Fluorescentes: essas lâmpadas contêm mercúrio em forma de vapor e aquelas descartadas são armazenadas no almoxarifado da Prefeitura do Campus, de onde seguem para descontaminação em uma empresa. A universidade arca com os custos desse processo, pagando cerca de $\mathrm{R} \$ 0,40$ pela descontaminação de cada lâmpada, em um consórcio entre todos os campi da USP. Em 2006 foram enviadas 5.022 lâmpadas fluorescentes para a descontaminação, provenientes de todas as unidades do campus de São Carlos.

Uma informação importante é a de que esse material é o único que gera custo para o consumidor final se desfazer, destinando às empresas de descontaminação, por possuir resíduos perigosos em sua composição, nocivos a saúde, sendo posteriormente feito a sua reciclagem. 


\subsection{6 - Iniciativas para a Minimização de Resíduos Sólidos no Campus de São}

\section{Carlos}

\section{Substituição permanente de copos descartáveis por similares duráveis}

Implantado no Restaurante Universitário, desde novembro de 2003, que serve cerca de 3 mil refeições/dias. Cada usuário possui uma caneca lavável e durável, como na Figura 4.3, evitando dessa forma o desperdício de materiais utilizados na produção e descarte de copos plásticos. Além disso, evita que o destino desses copos (500 mil/ano) seja o aterro sanitário municipal.

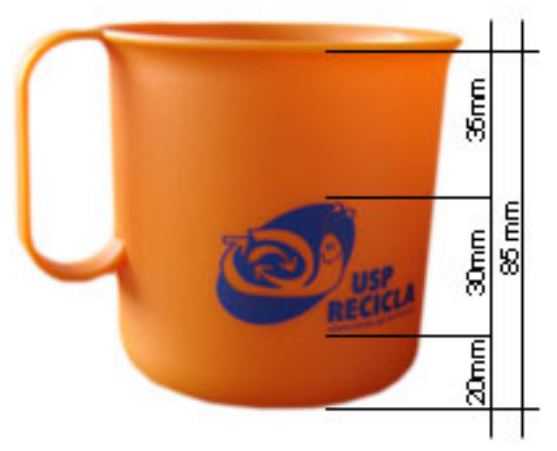

Figura 4.3: Canecas individuais duráveis no Restaurante Universitário. Fonte: USP Recicla ${ }^{\odot}$ (2003)

\section{Redução na utilização do papel}

- Imprimir somente o necessário, fazer impressões e cópias utilizando a frente e verso do papel;

- Elaboração de dissertações e teses frente e verso dos alunos de pós-graduação do campus. Em reunião realizada em 26/06/2006 pela Comissão de Pós-Graduação (CPG), deliberou-se, por unanimidade, que a partir de julho deste mesmo ano, começasse a se cumprir este regimento; 
- Utilizar meios eletrônicos para comunicação, evitando a utilização desnecessária de papel.

\section{Reutilização de produtos e materiais}

- Reaproveitar papel para rascunho;

- Feira da Sucata e da Barganha: os participantes trazem objetos usados de suas casas para trocar, vender ou doar e ainda tem oportunidade de realizar pequenos consertos de roupas, calçados e bicicletas. A Feira nasceu em 1999 de uma parceria do USP Recicla com a Organização Não-Governamental (ONG) Associação para Proteção Ambiental de São Carlos (APASC). A sua $7^{\mathrm{a}}$ edição realizada em 2005 contou com 180 expositores e mais de 5.000 visitantes.

Com o sucesso da Feira da Sucata e da Barganha, e com o mesmo objetivo, foi implantada em 2007, a Feira do Bixo. O público são os alunos veteranos e os alunos ingressantes da universidade, na qual esses últimos estão à procura de objetos usados para suas residências e materiais escolares. Dessa forma os alunos veteranos promovem a interação com os calouros vendendo, trocando e doando seus objetos, beneficiando ambas as partes.

\subsection{7 - Resultado dos Programas USP Recicla (Ano Base: 2005)}

- Campi envolvidos - 06;

- Unidades e Órgãos envolvidos - 63;

- Estudantes USP envolvidos diretamente no Programa - 56 alunos; 
- Participantes de encontros, palestras e eventos - 23.816 (comunidade interna e externa);

- Palestras Calouradas, Oficinas Temáticas e Eventos - 149 (comunidade interna e externa);

- Inserção na mídia = 89 (escritas, rádio/TV e eletrônicas);

- Atendimento a consultas - 1.202 (e-mails, telefone, visitas);

- Redução de lixo - 50\% a $70 \%$ em peso.

\subsection{8 - Organização do Programa USP Recicla}

O Programa Permanente para assuntos relativos à Gestão e Gerenciamento Compartilhado de Resíduos Sólidos, denominado USP Recicla, baseia-se em um modelo de organização específico constituído por um conjunto de instâncias e atores. Reconhecendo e respeitando as diferenças de atribuições, interesses e capacidades, busca-se articular uma rede de envolvidos, integrando-os em metas e ações convergentes. (USP Recicla ${ }^{\odot}, 2003$ )

De acordo com USP $\operatorname{Recicla~}^{\circ}$ (2003), a proposta do Programa é o compartilhamento de poder e de responsabilidades entre os diretamente envolvidos, sendo composto por: Conselho Acadêmico, Comitê Gestor, Comissões Locais, Comissões Internas e equipe CECAE - USP Recicla .

A constituição do Programa Permanente para assuntos relativos à Gestão e Gerenciamento Compartilhado de Resíduos Sólidos da Universidade de São Paulo está regulamentada na Portaria GR- 3.544, de 19 de janeiro de 2005 (http://www.cecae.usp.br/recicla/portaria.asp.htm). 
Na Figura 4.4, segue um esquema da estrutura organizacional do Programa USP Recicla, sob coordenação da Agência USP de Inovação:

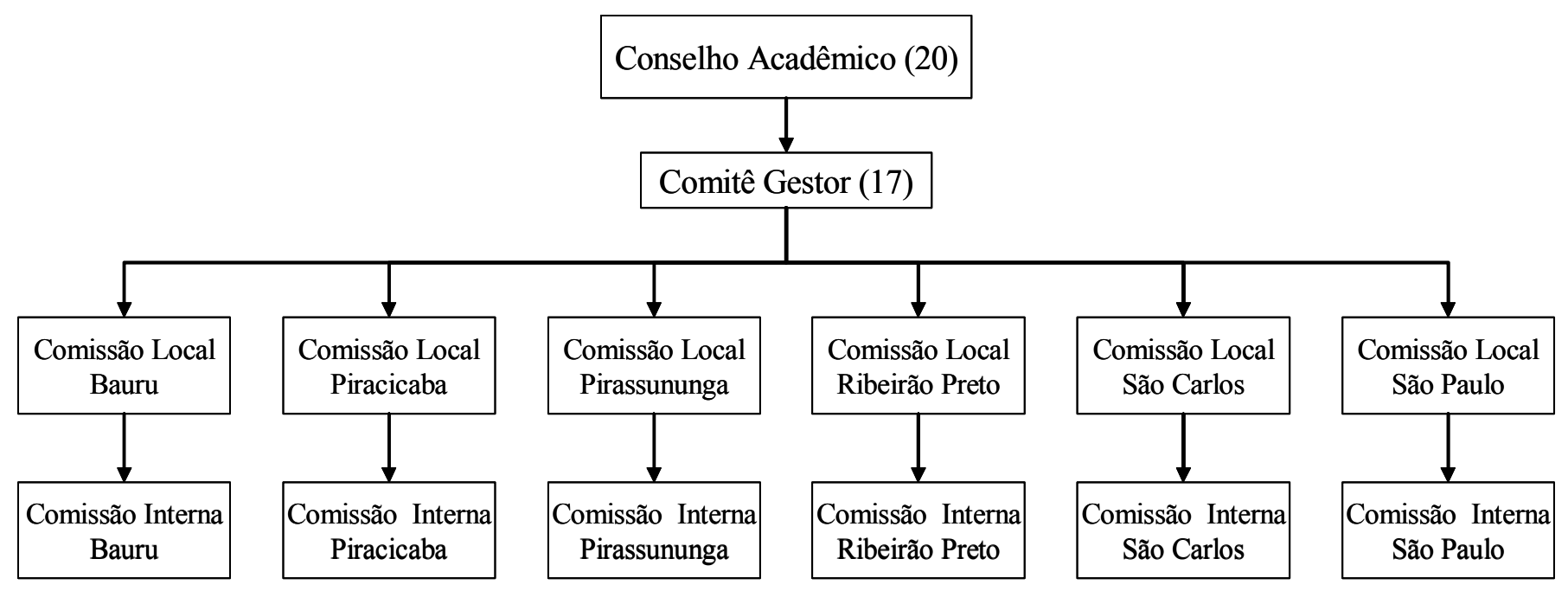

Figura 4.4: Organização do Programa USP Recicla/Agência USP de Inovação, de acordo com a Portaria GR - 3.544, de 19 de janeiro de 2005.

O Conselho Acadêmico, órgão consultivo deliberativo do Programa, é responsável pelo respaldo institucional e pelo fortalecimento da interface com a sociedade.

O Comitê Gestor, instância de planejamento do Programa, subsidia o Conselho Acadêmico na definição de diretrizes gerais e na avaliação do Programa. Também é um importante agente de articulação entre as demais instâncias USP Recicla.

A reunião dos coordenadores de comissões de unidades ou órgãos compõe a Comissão USP Recicla Local daquele Campus. Responsável por articular as comissões de unidades/órgãos e elaborar, junto com elas, o planejamento das ações locais, as 
Comissões dos Campi atuam como um elo entre as comissões das unidades/órgãos e as demais instâncias do Programa.

Em cada uma das unidades e órgãos da Universidade é estimulada a formação de uma Comissão Interna USP Recicla. Estas comissões são responsáveis pela implementação e operação do Programa nas unidades ou órgãos, considerando suas características específicas e as diretrizes definidas pelas demais instâncias USP Recicla. Tais comissões são compostas por docentes, funcionários e estudantes indicados pelo dirigente ou escolhidos pela comunidade da unidade/órgão.

No campus de São Carlos, a Agência USP de Inovação conta com uma equipe, vinculada ao Programa USP Recicla, que é responsável pelo cumprimento de operações técnicas, educativas e administrativas do Programa no local. Essa equipe, no total de 11 pessoas, é formada por um educador ambiental (que também é responsável pelo campus de Pirassununga) e por 10 (dez) estudantes estagiários (entre bolsistas e voluntários) de diversos cursos da USP São Carlos.

As comissões do campus, estas são formadas desde 2004, na qual conta com uma Comissão Interna em cada unidade do campus e com uma Comissão Local, formada por um representante de cada unidade, ou seja, o coordenador dessa unidade. A Comissão Local ainda possui um coordenador e vice-coordenador. 


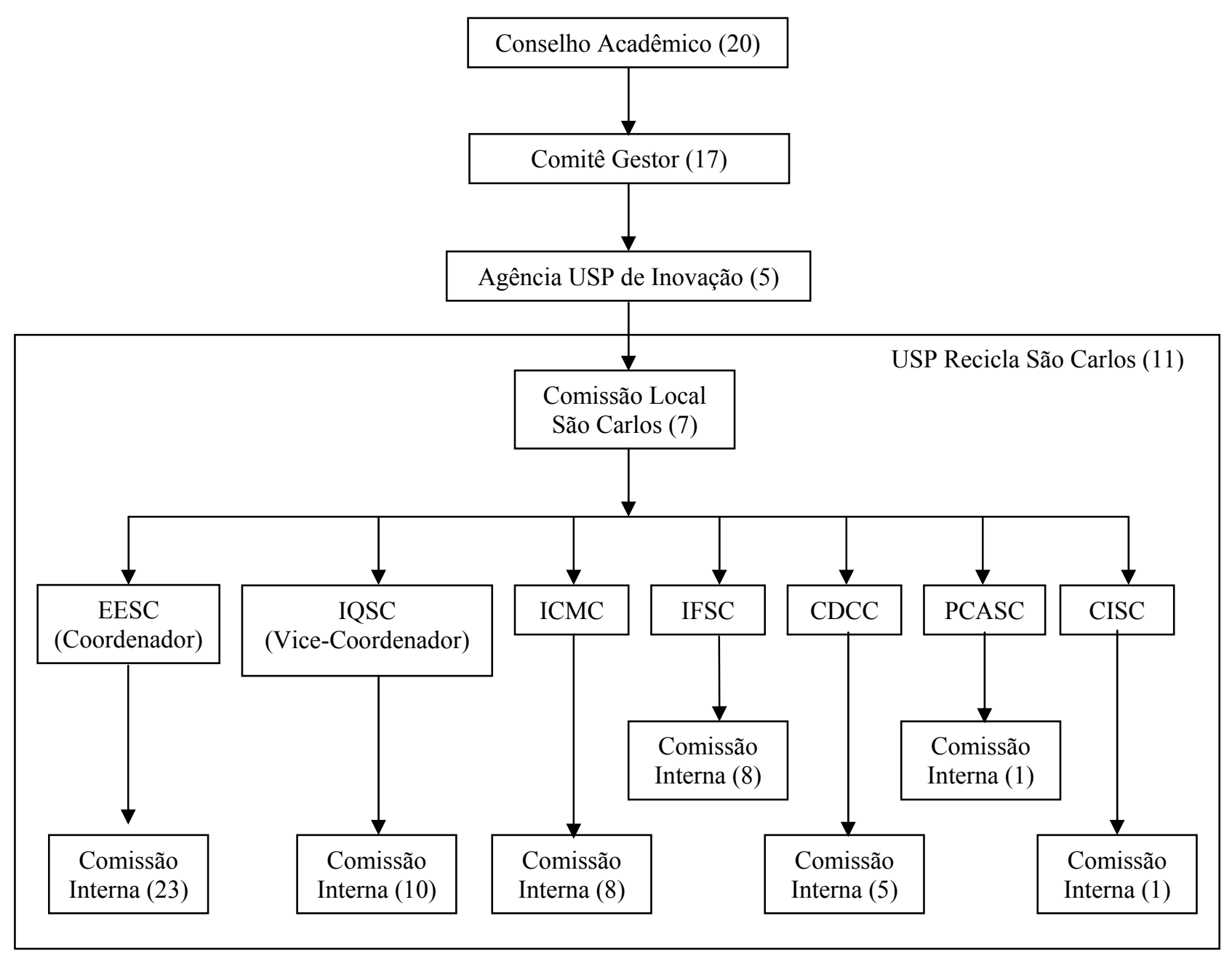

Figura 4.5: Organização do Programa USP Recicla São Carlos.

Número de integrantes entre parênteses. 


\section{2 - PROGRAMA DE RECICLAGEM DA UNIVERSIDADE FEDERAL DE SÃO CARLOS}

\subsection{1 - Informações Gerais sobre o Programa}

O programa de reciclagem da UFSCar, localizado na cidade de São Carlos, desenvolvido pela Reitoria da universidade em parceria atualmente com a Prefeitura Municipal da cidade, tem como público-alvo do programa os integrantes da Cidade Universitária, que são aproximadamente 9.100 pessoas: 7.500 alunos, 900 docentes e 700 funcionários. Também disponibiliza a entrega de materiais recicláveis no campus a comunidade externa.

Com a nova parceria com a Prefeitura Municipal, o programa de coleta seletiva de resíduos comuns é supervisionado por um funcionário e conta com o apoio indireto de outros, como pessoal da equipe terceirizada de limpeza do campus e pessoal das Cooperativas de Catadores da cidade. O material gerado é doado às cooperativas como forma de incentivo ao seu funcionamento.

\subsection{2 - Surgimento e Estrutura Organizacional do Programa}

Em outubro de 1993 a UFSCar criou a Coordenadoria Especial para o Meio Ambiente (CEMA) com a tarefa de criar um projeto ambiental. A CEMA tem ligação direta com a Reitoria para estar sempre à frente no processo de promover, junto aos membros da comunidade, o desenvolvimento ecológico.

Ao longo dos anos, a CEMA incorporou alguns programas como o Programa Agro-Ecológico (PAE), que tem como objetivo principal a otimização no uso da terra, e deu origem a dois outros programas: o Programa de Conservação de Energia e Controle de Resíduos (PCE), que envolve principalmente a conservação de água, energia elétrica, 
coleta seletiva, e o Programa de Educação Ambiental (PEAm) - voltado para projetos de educação ambiental. O PCE ainda incorpora a Unidade de Gestão de Resíduos (UGR), unidade que gerencia os resíduos sólidos do campus.

Dentre as várias atividades desenvolvidas por estes programas, pode-se destacar a ocupação das áreas rurais do campus de São Carlos, através de reflorestamento e criação de reservas legais, a elaboração de um projeto de coleta seletiva de materiais recicláveis, medidas de conservação de energia elétrica, campanhas educativas e atividades de educação ambiental.

Na figura 4.6 é apresentado o organograma do Programa de Reciclagem da UFSCar.

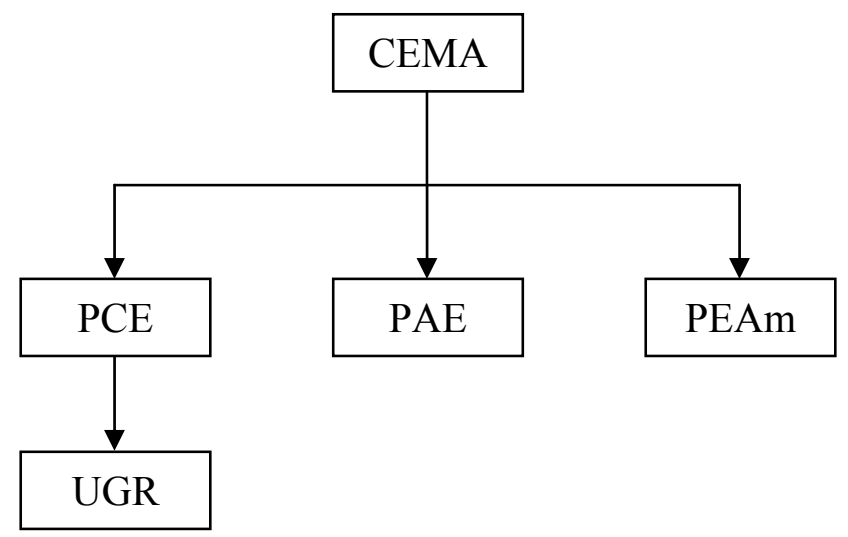

Figura 4.6: Organização do Programa de Reciclagem UFSCar.

\subsection{3 - Objetivos do Programa}

Dentro do PCE, constam as seguintes iniciativas:

- Promover estudos e estabelecer medidas de controle sobre a utilização de produtos tóxicos e destinação de resíduos;

- Planejar a coleta seletiva, o aproveitamento do lixo e sua conseqüente operacionalização; 
- Propor, orientar e acompanhar estudos diagnósticos e medidas efetivas para a conservação de energia (combustíveis, energia elétrica);

- Promover estudos e propor medidas para o tratamento de água e esgoto da UFSCar;

- Promover estudos e estabelecer medidas para o controle do desperdício de água;

- Outras atribuições determinadas pela Administração e/ou necessárias para o desenvolvimento do programa.

\subsection{4 - O Funcionamento da Coleta Seletiva no Campus}

Em 2000 foram construídas as instalações da Central de Resíduos, sendo renomeada para Unidade de Gestão de Resíduos (UGR), que foi criada oficialmente em 2005, cuja função é a operação de controle de resíduos.

A UGR dá suporte à gestão de resíduos da UFSCar, especificamente os resíduos químicos perigosos, os radioativos e os recicláveis. Os recicláveis contavam com a coleta seletiva em parceria com a Associação para Proteção Ambiental de São Carlos (APASC), através do Convênio de Cooperação Institucional, e atualmente, após o término do contrato com a APASC, com a Prefeitura Municipal de São Carlos.

Os resíduos comuns gerados pela universidade são de dois tipos, sólidos e úmidos, sendo o papel a matéria bruta em maior quantidade e merecendo principal atenção para sua redução e reciclagem:

- Resíduos Recicláveis Sólidos (RRS): são os resíduos recicláveis que vão para a coleta seletiva, tais como papéis, garrafas plásticas, metais e vidros. 
- Resíduos Recicláveis Úmidos (RRU): são os resíduos utilizados em compostagem, tais como poda de árvores, vegetações e outros.

Até a parceria com a APASC, em meados de 2005, os recicláveis eram acondicionados conjuntamente em um único recipiente, em contêineres espalhados em pontos estratégicos do campus, onde eram recolhidos e levados à Central de Resíduos, localizada no campus, separados os matérias limpos e secos, prensados e triados. O material gerado era vendido a indústrias de reciclagem e sua receita era para manter os dois funcionários da APASC em atividade no campus, cobrir os custos fixos e variáveis do programa, sendo o lucro destinado à manutenção e expansão desta.

Com o recorrente déficit na relação receita/despesa desde a implantação da parceria, que era sempre subsidiado pela UFSCar, decidiu-se por outra forma de gerenciamento dos resíduos na universidade sem comprometimento com os custos, mas simplesmente com a doação dos materiais. Surgiu assim uma nova parceria, firmada com a Prefeitura Municipal de São Calos e com as três Cooperativas de Catadores existentes na cidade.

O processo de acondicionamento é igual ao anterior, no entanto os contêineres são utilizados exclusivamente para os papéis. A Prefeitura Municipal fornece o caminhão para o transporte dos materiais do campus para as cooperativas, e estes últimos, utilizam seus funcionários para a movimentação do veículo e coleta dos materiais, que são doados pela universidade, com o intuito de incentivar a geração de empregos, a educação e sustentabilidade ambiental.

Desde o início do programa de coleta seletiva pela CEMA, o pessoal terceirizado da equipe de limpeza é orientado a coletar o papel nas unidades e departamentos da universidade, que fica depositado em caixas de papelão espalhadas 
pela universidade, armazená-lo em sacos de ráfia nas próprias unidades e, posteriormente, transportar aos contêineres mais próximos.

O restante dos recicláveis é levado a um Ponto de Entrega Voluntária (PEV), que se localiza na entrada principal do campus. Devido à pequena quantidade desses materiais gerados pela universidade, estes são incorporados aos deixados pela população local, funcionários, estudantes e professores, e retirados pelas Cooperativas.

Um empecilho às Cooperativas é a coleta antecipada, seja por funcionários aposentados da universidade, que utilizam a venda dos resíduos para complemento de renda familiar, ou por catadores autônomos, que ainda não foram agregados ao programa das Cooperativas realizado pela Prefeitura Municipal.

\subsection{5 - Iniciativas para a Minimização de Resíduos Sólidos no Campus}

\section{1) Substituição de copos descartáveis por similares duráveis}

Esta iniciativa partiu diretamente de um grupo de alunos preocupados com a redução de resíduos, com o apoio da CEMA, e acontece no Restaurante Universitário em que alunos, funcionários e docentes recebem gratuitamente uma caneca durável da UFSCar.

O uso massivo das canecas duráveis mostra que os alunos estão cientes de que cada um pode fazer sua parte para a diminuição de lixo e adequação ambiental. Estes, ainda, utilizam as canecas em festas, em casa e em outros ambientes, disseminando essa consciência ecológica à comunidade.

\section{2) Programa de Educação Ambiental - PEAm}

Os projetos ainda estão em fase de estudo e constam das seguintes iniciativas: 
- Planejar e coordenar campanhas visando o aprimoramento da consciência ambiental da comunidade universitária;

- Planejar atividades com estudantes do ensino Médio, Fundamental e Básico através de cursos, visitas, mini-projetos etc.;

- Incentivar a elaboração e difusão de textos de conteúdos básicos e de experiências simples e econômicas;

- Promover e difundir vídeos, textos, cartazes e outros instrumentos de divulgação com vistas à educação ambiental;

- Promover o treinamento sistemático de monitores, principalmente alunos de graduação da UFSCar, com vistas a uma atuação mais eficiente na área de educação ambiental.

\subsection{6 - Dados sobre a Coleta Seletiva no Campus}

Até o término da parceria com a APASC, eram geradas duas tabelas, uma da receita do programa e outra a despesa mensal gerada. Assim, a relação receita/custo era analisada.

A seguir, é apresentada a tabela 4.1, referente ao resumo do acumulado anual receita $\mathrm{x}$ despesa $\mathrm{x}$ saldo e posteriormente a tabela 4.2 apresenta o total anual gerado de papel e o acumulado de todos os recicláveis. Os dados são relativos ao ano de 2002 até o fim da parceria com a APASC, que ocorreu em agosto de 2005.

Tabela 4.1. Total anual Receita x Despesa x Saldo até o fim da parceria com a APASC.

\begin{tabular}{cccc}
\hline Ano & Receita (R\$) & Despesa (R\$) & Saldo (R\$) \\
\hline 2002 & $15.395,10$ & $17.174,43$ & $-1779,33$
\end{tabular}




$\begin{array}{cccc}2003 & 18.278,59 & 28.494,25 & -10.215,66 \\ 2004 & 16.431,61 & 23.040,07 & -6608,46 \\ 2005^{(*)} & 12.514,50 & 14.839,78 & -2325,28\end{array}$

${ }^{(*)}$ Dados referentes até agosto/2005.

Fonte: UGR (2006).

Tabela 4.2. Total anual e acumulado de papel e recicláveis até o fim da parceria com a APASC.

\begin{tabular}{ccc}
\hline Ano & Total Papel (kg) & Total Recicláveis (kg) \\
\hline 2002 & $59.136,0$ & $85.658,0$ \\
2003 & $46.369,0$ & $71.780,5$ \\
2004 & $42.370,0$ & $61.260,5$ \\
$2005^{(*)}$ & $32.510,0$ & $42.411,5$ \\
\hline
\end{tabular}

${ }^{\left({ }^{*}\right)}$ Dados referentes até agosto/2005.

Fonte: UGR (2006).

Houve um intervalo de um mês para o fechamento da nova parceria entre as partes, UFSCar - Prefeitura Municipal, iniciando a nova parceria em outubro de 2005 e em funcionamento desde então. Como dito anteriormente, o papel é doado às cooperativas, sendo que estas passam a UGR o peso total mensal como forma de análise da quantidade gerada (ver tabela 4.3). O restante dos recicláveis não é mensurado, pois são de pequena quantidade em comparação com o papel, além de sofrer influência dos resíduos trazidos externamente ao campus e de pessoas e catadores autônomos que coletam e interferem na pesagem total.

Tabela 4.3. Total mensal de papel com a nova parceria firmada.

\begin{tabular}{cc||cc}
\hline Mês/Ano & Total Papel (kg) & Mês/Ano & Total Papel (kg) \\
\hline Out/05 a & $9.750,0$ & Mai/06 & $4.820,0$ \\
Dez/05 & & Jun/06 & $4.840,0$ \\
Jan/06 & 4690,0 & Jul/06 & $4.000,0$
\end{tabular}




\begin{tabular}{cc||cc} 
Fev/06 & 3960,0 & Ago/06 & $5.140,0$ \\
Mar/06 & $5.260,0$ & Set/06 & $3.740,0$ \\
Abr/06 & 3600,0 & Out/06 & $4.160,0$ \\
\hline
\end{tabular}

Fonte: UGR (2006).

O total acumulado de papel, de acordo com a nova parceria com a prefeitura, de outubro de 2005 até outubro de 2006, ou seja, um ano de sua implantação, foi de $53.960,0 \mathrm{~kg}$.

Ainda não há estudo realizado no campus sobre a redução de lixo gerado desde a criação do programa de reciclagem, porém, pretende-se realizá-lo com os novos projetos de educação ambiental. 


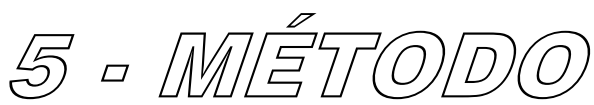

\section{1 - OBJETIVOS E JUSTIFICATIVAS}

Para se obter de um programa ou processo um desempenho eficiente e eficaz a gestão do conhecimento é fundamental, na medida em que mapeia as informações e conhecimento gerado, buscando organizar as melhores práticas. Além disso, esses programas de Reciclagem carregam os princípios de Logística Reversa quando entram no mérito da Gestão de Resíduos e há a necessidade de verificar se atendem aos conceitos da mesma.

Portanto, este trabalho tem como principal objetivo analisar a forma pela qual o fluxo de informação e conhecimento apresenta-se nos programas de Reciclagem em duas Universidades, USP e UFSCar, e os comparar com os conceitos de logística reversa visando modificar procedimentos inadequados porventura adotados.

Desta forma, os programas de reciclagem serão analisados utilizando-se os conceitos de Gestão do Conhecimento, composto por conhecimento aplicado, criado, armazenado e distribuído e que visa, entre outros objetivos, aperfeiçoar a criação e o fluxo de conhecimento em uma organização e no contexto da Logística Reversa.

Após essas considerações, a hipótese que o presente trabalho apresenta é que se o fluxo de conhecimento for melhor mapeado e estruturado, os programas de Reciclagem podem ter ganhos em sua organização, melhorando assim seus processos internos, a relação receita/despesa e a agilidade na tomada de decisões. 
Essa análise foi baseada em um estudo bibliográfico e posterior pesquisa de levantamento que, segundo Selltiz (1987), é a estratégia de pesquisa que visa avaliar a incidência relativa, distribuição e inter-relações de fenômenos que ocorrem naturalmente através da coleta de dados de uma população ou parte dela.

A coleta de dados foi feita através de questionários direcionados e espera-se que, com o processamento e análise dos dados, melhorias possam ser sugeridas na organização, visando um melhor fluxo de informação e conhecimento, aperfeiçoando os programas estudados e, também, criar perspectivas para posteriores estudos e projetos.

A pesquisa em questão é pouco estudada no meio científico. Agrega uma ferramenta de gestão empresarial, no caso, a gestão do conhecimento, à logística reversa, utilizada em programas que atualmente são de grande importância para as organizações e futuramente poderão ser essenciais para sua sobrevivência.

\section{2 - COMPARAÇÃO DOS PROGRAMAS COM A LOGÍSICA REVERSA}

Por ser um conceito recente, a logística reversa é frequentemente confundida como simples reciclagem de materiais, mas é mais que isso. De acordo com Leite (2003), é uma área da cadeia de suprimentos responsável por planejar, implementar e controlar eficientemente o fluxo reverso de produtos, serviços e de toda informação relacionada ao ciclo de negócios ou ao ciclo produtivo, agregando valor econômico, ecológico, legal e logístico. Assim, faz-se necessária a comparação da Logística Reversa com as características apresentadas pelos programas estudados.

As considerações acerca da Logística Reversa nos programas estudados são apresentadas no Capítulo 7. 


\section{3 - A GESTÃO DO CONHECIMENTO NOS PROGRAMAS}

Com o estudo dos programas através da análise de sua organização e dos questionários aplicados busca-se identificar o fluxo de conhecimento e verificar se melhorias podem ser propostas em relação a esse fluxo.

As sugestões e considerações acerca da Gestão do Conhecimento são apresentadas no Capítulo 7.

\section{4 - ESTUDO DOS PROGRAMAS}

Consiste no estudo do tipo de organização envolvido nos programas de reciclagem da UFSCar e USP, ou seja, seu histórico e sua evolução, seus organogramas, estruturas, missão e estratégia, métodos de trabalhos, de onde vêm os recursos para a manutenção dos programas por serem sem fins lucrativos, resíduos gerados e destino destes, iniciativas para o combate ao desperdício de materiais e outras características relevantes. A descrição dos programas foi apresentada no Capítulo 4 do trabalho.

\section{5 - OBTENÇÃO DOS DADOS}

A coleta de dados foi feita através da análise de questionários direcionados aos integrantes e envolvidos dos programas, procurando abordar os conceitos da Gestão do Conhecimento, mais especificamente como o conhecimento é estimulado, criado, distribuído, compartilhado e armazenado.

Para isso, diferentes questionários foram aplicados de acordo com a função dos entrevistados. Um tipo de questionário foi aplicado aos Gestores dos programas, outro aos funcionários dos programas e um terceiro ao público-alvo ou clientes dos programas. Essa diferenciação foi necessária, pois os entrevistados desempenham 
atividades diferentes em relação aos programas de reciclagem. A aplicação de apenas um questionário seria muito confusa, tanto para as pessoas responderem perguntas que não representassem sua função, tanto para a análise dos resultados por parte dos pesquisadores.

Os gestores dos programas são os responsáveis pela criação desses programas e pela elaboração de suas diretrizes gerais. Também compõe o grupo de gestores aqueles que gerenciam o programa dentro da universidade analisada.

Os funcionários dos programas são os que recebem instruções superiores para o desenvolvimento e aprimoramento dos processos internos em suas unidades dos campi. São as pessoas que não tem poder de tomada de decisão dentro dos programas, somente as fazem cumprir.

O público-alvo dos programas ou clientes são as comunidades dos campi, são as pessoas que são atingidas pela política e ações dos programas.

Com a identificação das pessoas a serem entrevistadas e a definição dos questionários, foi necessária a determinação do número amostral. Esse número foi definido através dos conceitos apresentados por Barbetta, Reis e Bornia (2004), que mostram que:

$n \approx \frac{N .400}{\mathrm{~N}+400-1}$, para uma amostra onde se deseja um nível de confiança de 95\% e um erro amostral máximo de 5\%.

Onde:

$n$ : tamanho da amostra para a respectiva classe entrevistada de tamanho N. $N$ : total de membros que compõe a respectiva classe entrevistada. 
Com a equação do número amostral definida, fez-se o cálculo do mesmo. É importante mencionar que esse cálculo foi utilizado somente para o grupo de clientes. Nos grupos de gestores e funcionários a estratégia usada foi diferente, por se tratar de um número reduzido de pessoas. Nesses dois grupos a estratégia utilizada foi a de entrevistar o maior número de pessoas possível.

Com o objetivo de abranger toda a comunidade de clientes, o lugar escolhido para pesquisa foi o Restaurante Universitário (RU) de cada Universidade, pois são lugares onde quase toda comunidade universitária freqüenta e porque tem uma estrutura similar de funcionamento em ambas as universidades. O número amostral de clientes nos programas á apresentado na Tabela 5.1, sendo importante mencionar que os dados de população considerados são os números de refeições servidas diariamente pelos RU's de cada universidade.

Tabela 5.1. Número amostral de clientes.

\begin{tabular}{ccc}
\hline Programa & População $(N)$ & Número amostral $(n)$ \\
\hline USP & 2500 & 345 \\
UFSCar & 2000 & 334 \\
\hline
\end{tabular}

Assim, de posse desses dados, definiu-se o tamanho da amostra em 350 pessoas.

\subsection{1 - PESQUISA PILOTO}

Com o delineamento da pesquisa definida considerou-se necessária a validação do instrumento de pesquisa (questionário), e para verificar possíveis falhas e melhorias a serem feitas no questionário. 
Para validar o questionário dos clientes foi definida uma amostra de 50 pessoas. Essa pesquisa-piloto foi realizada em um único dia, 03 de maio de 2007, com os clientes no RU da USP.

No caso dos funcionários, o tamanho da amostra piloto foi definida em 10 pessoas e os gestores, por se tratar de pessoas com maior dificuldade de acesso, foi aplicado somente um questionário piloto.

A pesquisa-piloto foi considerada de grande importância, pois proporcionou material para a melhoria do questionário definitivo. As questões com maior índice de dúvidas foram reformuladas e algumas questões consideradas desnecessárias foram excluídas.

\subsection{2 - PESQUISA}

Após o questionário e o tamanho da amostra serem definidos, traçou-se um plano para realizar a pesquisa, que é descrita a seguir.

$\mathrm{Na}$ segunda e terceira semanas de maio foram realizadas as entrevistas com os clientes nos RU's da USP e UFSCar respectivamente. Algumas precauções foram tomadas para a escolha das datas como preocupação com o cardápio, que tem grande influência no número de refeições, e escolha de semanas típicas com cinco dias úteis. Também se priorizou o início da semana para as entrevistas, já que nesses dias ocorre o maior fluxo de pessoas.

No caso dos funcionários dos programas as entrevistas com essas pessoas foram realizadas durante todo o mês de maio de 2007. Um pesquisador assumiu a função e entrou em contato com o maior número delas. As formas utilizadas para aplicação do questionário foram: contato direto, encaminhamento de e-mails e contato telefônico, 
solicitando a resposta dos questionários. Dos 61 funcionários, $50(82 \%)$ responderam o questionário.

O contato com os gestores dos dois programas foi feito por um pesquisador e ocorreu durante todo o mês de maio mais a primeira semana do mês de junho de 2007 . Como no caso da USP os gestores são divididos em vários campi, diferentes estratégias foram adotadas. Com os gestores do campus de São Carlos foi mantido contato direto, já paras os gestores de outros campi foi necessário o encaminhamento de e-mails. Dos 52 gestores em atividade em 2007 na USP, 42 (81\%) responderam o questionário. $\mathrm{Na}$ UFSCar o método utilizado foi o contato direto, além do encaminhamento dos questionários para os e-mails dos envolvidos e o contato por telefone. Dos 23 gestores da UFSCar, 13 (57\%) responderam o questionário.

Com os dados obtidos pelos questionários, puderam ser feitas as análises dos resultados tendo em vista o conceito da Gestão do Conhecimento para os programas de reciclagem da USP e da UFSCar, analisando-se esses programas conjuntamente, com o objetivo também da comparação de ambos. 
Com a fase de pesquisa terminada e de posse dos questionários os dados foram separados de acordo com o tipo de entrevistado, como feito nos questionários, e serão apresentados em gráficos cujo conteúdo apresenta os dados para os dois programas pesquisados no caso dos gestores e clientes. No caso dos funcionários, os gráficos só apresentam dados para o Programa da USP, já que na UFSCar não tem-se pessoas que se caracterizam como funcionários do programa.

Para ajudar o leitor na análise, os questionários são apresentados no Anexo "A" e as tabelas que geraram os gráficos são apresentados no Anexo "B".

Além disso, os dados obtidos foram agrupados para facilitar a apresentação dos mesmos. Essa divisão se deu da seguinte forma:

Tabela 6.1. Agrupamento dos índices pesquisados.

\begin{tabular}{cc}
\hline Índices & Índices agrupados \\
\hline 0 & 0 \\
\hline 1 & 1,2 e 3 \\
2 & \\
3 & 4,5 e 6 \\
\hline 4 & \\
5 & \\
6 & 7,8 e 9 \\
7 & \\
8 & 10 \\
9 &
\end{tabular}




\section{1 - RESULTADOS OBTIDOS PARA O GRUPO DE GESTORES}

Nesse capítulo serão apresentados somente os resultados obtidos para o grupo de gestores. Na USP foram entrevistados 42 gestores, o que representa $81 \%$ de um total de 52. Na UFSCar foram entrevistados 13 gestores, o que representa $57 \%$ de um total de 23.

O questionário primeiramente caracterizou os gestores de acordo com o sexo e cargo que ocupam nas instituições. Esses dados são apresentados nas figuras 6.1 e 6.2.

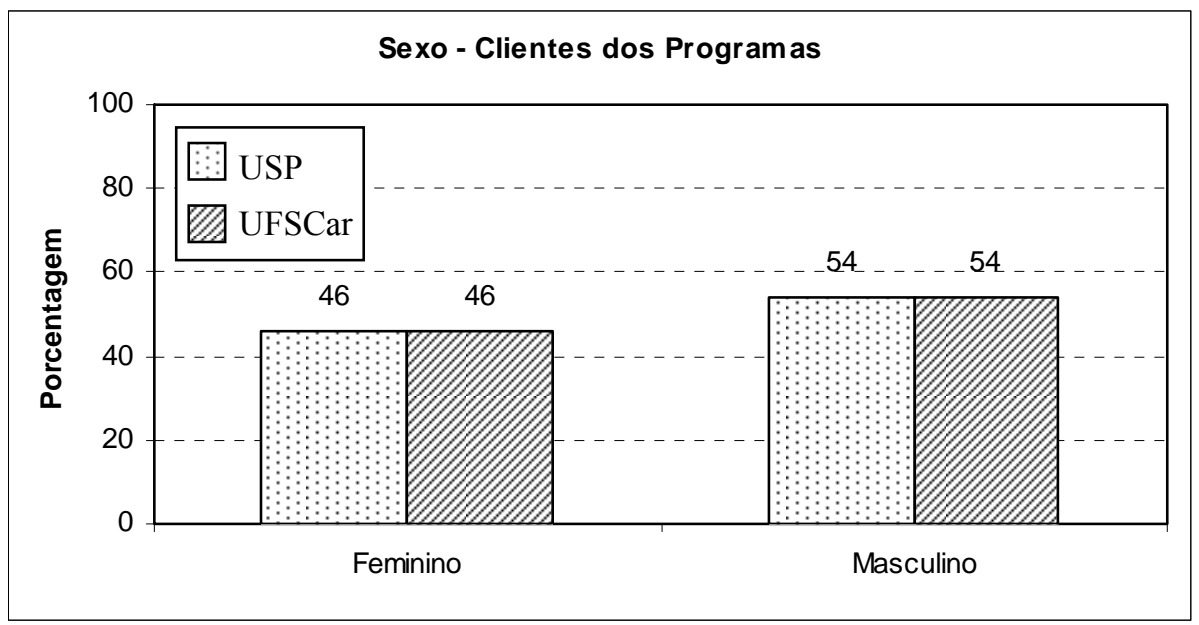

Figura 6.1: Caracterização dos gestores da USP e da UFSCar.

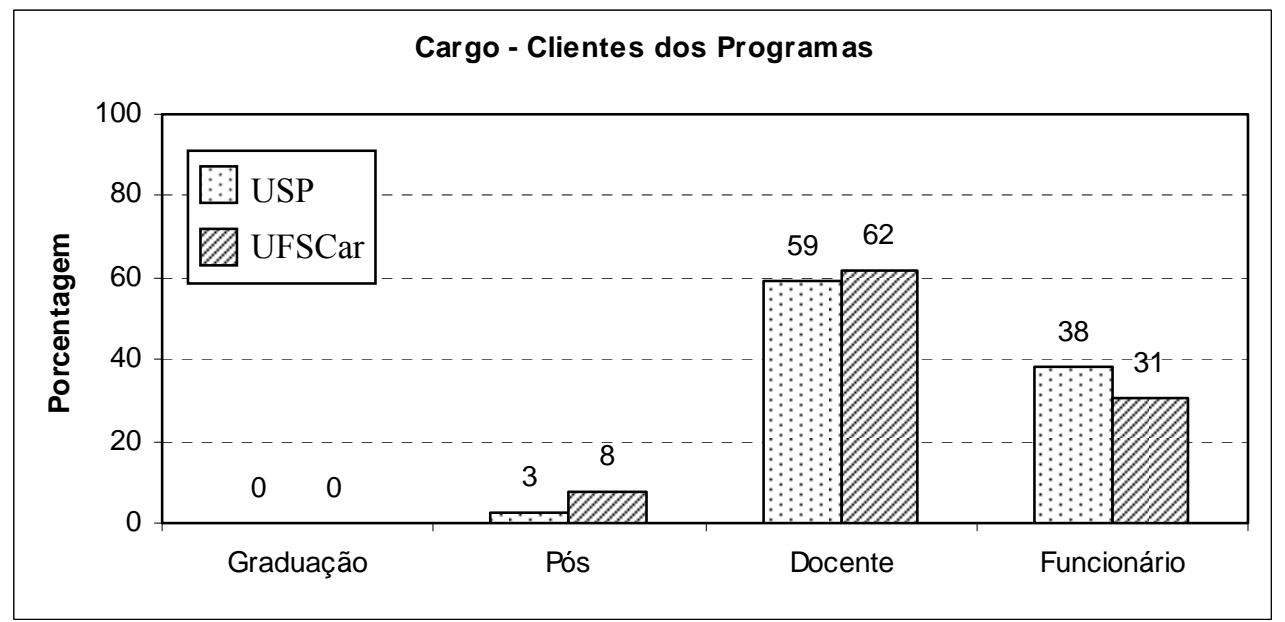

Figura 6.2: Caracterização dos gestores da USP e da UFSCar. 
Como se pode notar os dois programas possuem características muito semelhantes de seus constituintes, ambos com uma quantidade ligeiramente maior de gestores do sexo masculino, 56\%, e em sua maioria docentes, que representam aproximadamente $60 \%$ do quadro de gestores em ambos os programas. Completando o quadro de gestores tem-se os funcionários das instituições representando na USP cerca de $47 \%$ e na UFSCar $30 \%$ do quadro de gestores e, também, alunos de pós-graduação com uma quantidade bem inferior, $2 \%$ na USP e $8 \%$ na UFSCar.

Não se nota a presença de alunos de graduação no quadro de gestores dos dois programas estudados. Isso pode ser negativo, pois pode dificultar que a visão do aluno seja levada até a gestão dos programas, que problemas rapidamente identificados pelos alunos, que são os clientes dos programas, sejam resolvidos e que necessidades observadas pelos mesmos sejam atendidas.

Após isso a análise das questões do questionário será feita individualmente, questão por questão. Cada questão terá seu intuito e um gráfico que mostrará os índices de respostas obtidos e, posteriormente, uma análise dos resultados que pode ser em conjunto com outras questões complementares.

A questão 01 do questionário teve a intenção de verificar se o trabalho nos programas vem sendo melhorado e com isso, se o conhecimento está sendo utilizado com essa finalidade. Para isso a seguinte afirmação foi formulada:

- Observo melhorias nos processos internos do Programa

Os entrevistados concordaram ou não com essa afirmação, em grau que variava de zero para índice "nunca” e dez para índice "sempre”.

As respostas obtidas podem ser vistas na figura 6.3. 


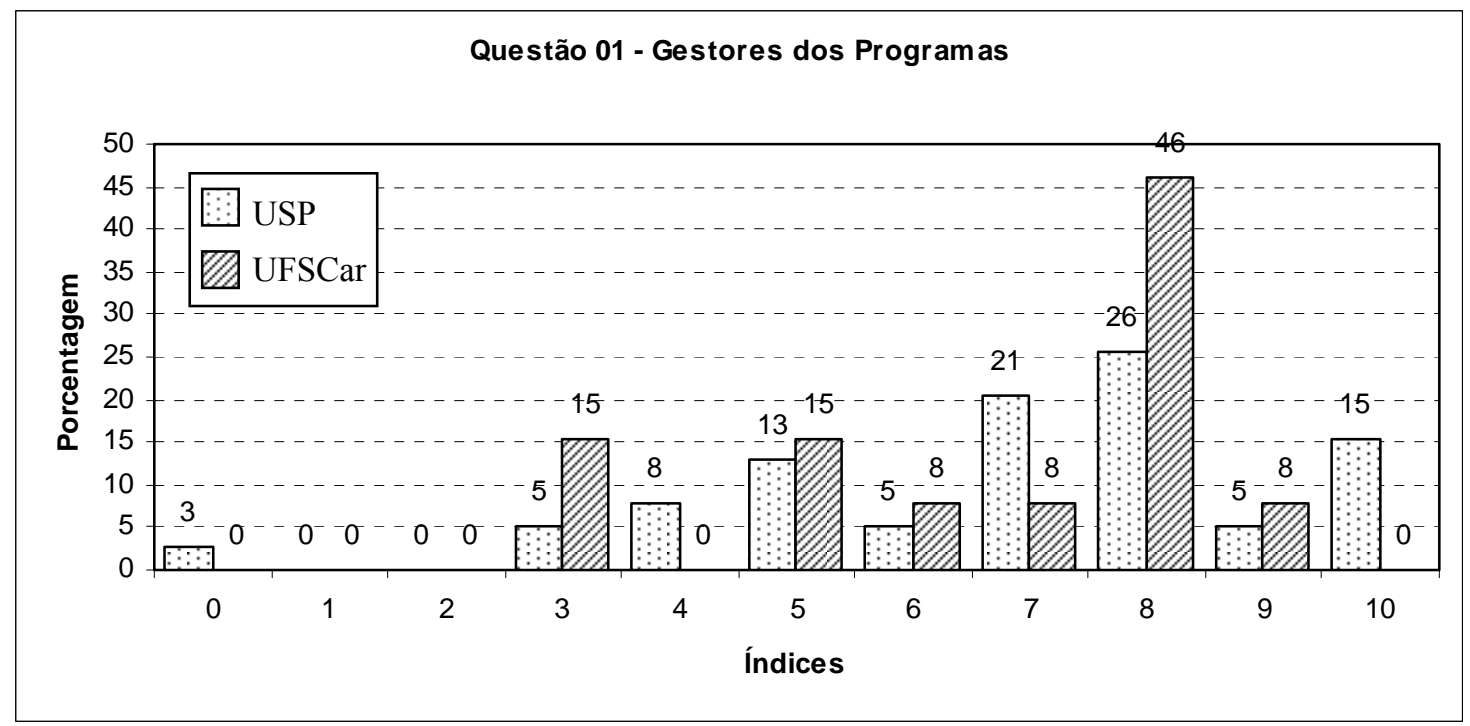

Figura 6.3: Respostas para questão 01 do questionário dos gestores.

De acordo com as respostas observa-se que na USP, aproximadamente, 50\% dos gestores do programa quase sempre observam melhorias nos processos internos do programa, enquanto, aproximadamente, $30 \%$ observam melhorias de maneira menos acentuada. $15 \%$ deles sempre observam melhorias.

Os gestores do programa da UFSCar têm opinião semelhante. Aproximadamente $60 \%$ dos entrevistados quase sempre observam melhorias nos processos internos do programa e, aproximadamente, $40 \%$ observam melhorias de maneira menos acentuada.

A média amostral apontou para 6,9 na USP e 6,6 na UFSCar, o que mostra realmente terem uma opinião próxima em relação a melhorias dos processos internos.

Esse resultado mostra que o conhecimento nos Programas está sendo útil para que melhorias sejam feitas e, mais do que isso, que o conhecimento está sendo aplicado nos programas.

A questão 02 do questionário teve a intenção de verificar se o conhecimento está sendo difundido. Para isso a seguinte afirmação foi formulada: 
- O Programa oferece cursos de aprendizado à comunidade do Campus

Os entrevistados concordaram ou não com essa afirmação, em grau que variava de zero para índice "nunca” e dez para índice "sempre”.

As respostas obtidas podem ser vistas na figura 6.4.

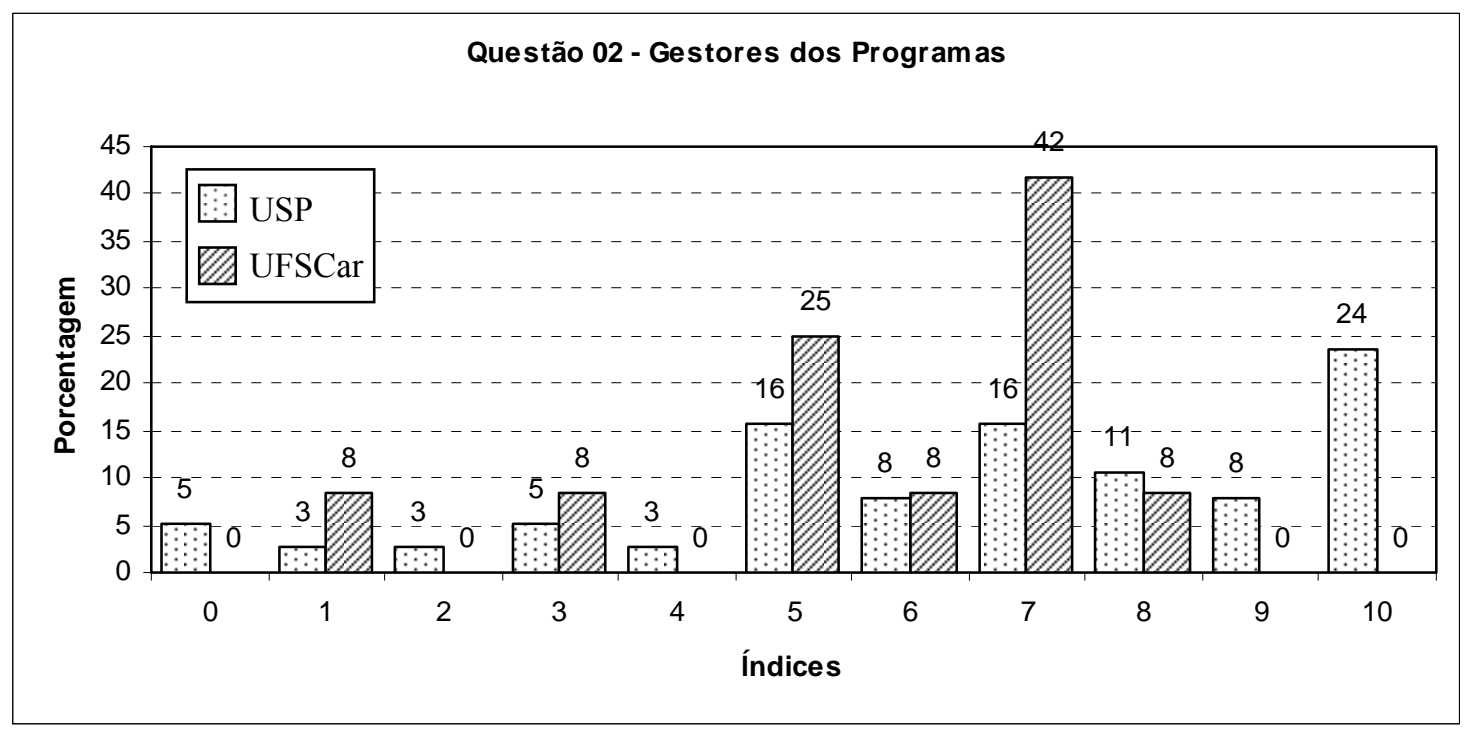

Figura 6.4: Respostas para questão 02 do questionário dos gestores.

De acordo com os gestores do programa da USP, para 24\% o programa sempre oferece cursos de aprendizado à comunidade, para 34\% o programa quase sempre oferece cursos, para $26 \%$ há cursos oferecidos moderadamente e $16 \%$ acreditam que nunca ou quase nunca são oferecidos cursos de aprendizado.

De acordo com os dados para os gestores do Programa da UFSCar, para 50\% deles o Programa quase sempre oferece curso de aprendizado, 33\% acreditam que os cursos são oferecidos de maneira moderada e $17 \%$ acham que quase nunca os cursos são oferecidos.

Em ambos os programas cerca de $15 \%$ dos gestores acreditam que nunca ou quase nunca são oferecidos cursos de aprendizado a comunidade dos campi. Isso pode 
mostrar uma pequena deficiência nesse quesito, que na realidade trata da difusão ou distribuição do conhecimento. Além disso, cerca de 30\% dos gestores de ambos os Programas tem como moderada a opinião sobre a quantidade de cursos oferecidos, o que é muito se for considerada a importância da etapa de difusão do conhecimento.

A questão 03 do questionário teve a intenção de verificar se o conhecimento é disponível aos seus potenciais utilizadores. Para isso a seguinte afirmação foi formulada:

- Para mim, o acervo de informações do Programa é de acesso

Os entrevistados concordaram ou não com essa afirmação, em grau que variava de zero para índice “difícil” e dez para índice “fácil”.

As respostas obtidas podem ser vistas na figura 6.5.

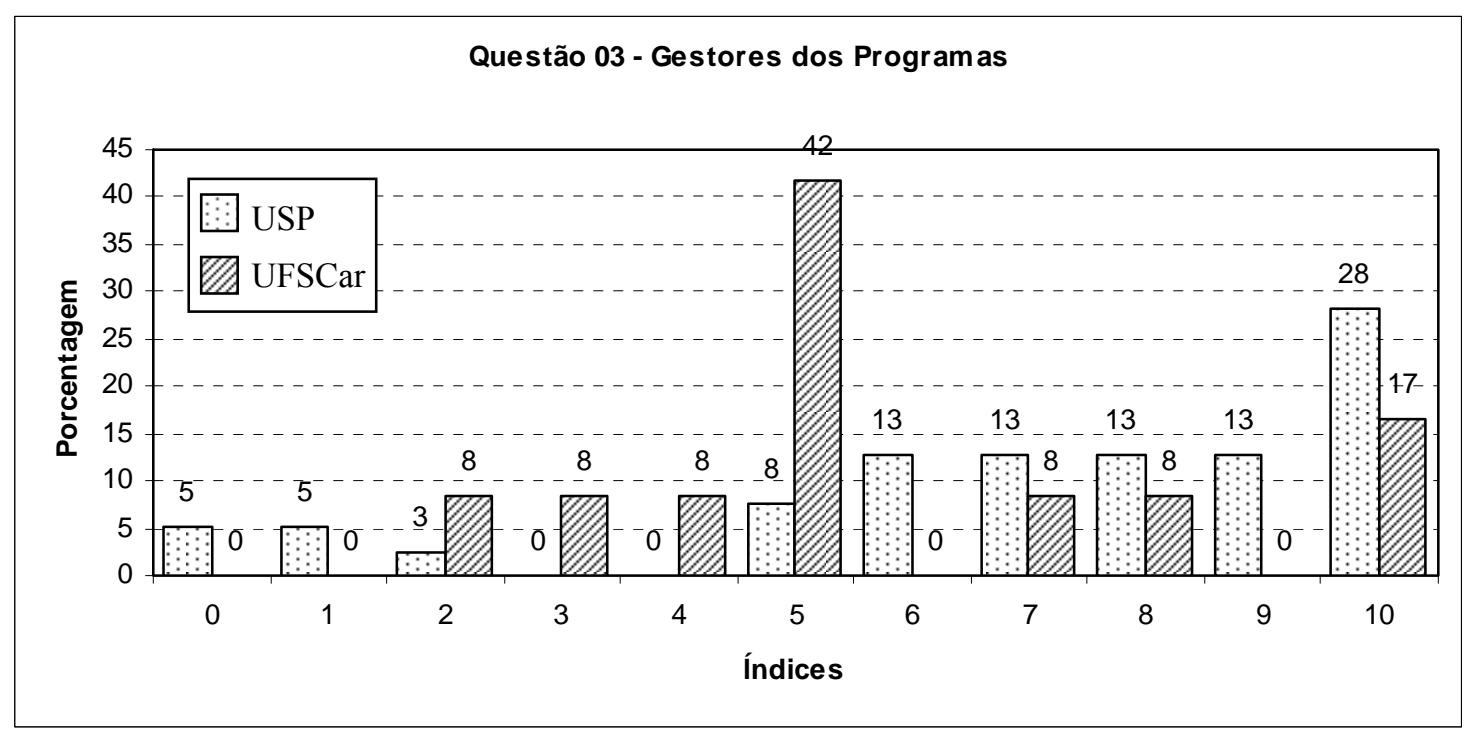

Figura 6.5: Respostas para questão 03 do questionário dos gestores.

Para os gestores do Programa da USP, 28\% têm o acervo de informações do Programa como de fácil acesso, $38 \%$ acredita que o acervo é de relativa facilidade, $21 \%$ 
tem a facilidade como moderada e $13 \%$ acreditam que o acervo é de difícil ou de relativa dificuldade de acesso.

Em relação aos gestores da UFSCar, $17 \%$ deles têm que o acervo de informações é de fácil acesso, outros $17 \%$ consideram que o acervo tem relativa facilidade de acesso, $50 \%$ acham que a facilidade de acesso é moderada e $22 \%$ acham que a acessibilidade ao acervo de informações é difícil ou de relativa dificuldade.

De acordo com os dados nota-se uma maior dificuldade de acesso às informações por parte dos gestores da UFSCar em relação aos da USP. Embora a dificuldade de acesso dos gestores da UFSCar não seja tão acentuada, ela pode conduzir à falta de dados para análise dos programas e para a melhoria do mesmo. Também pode indicar que o armazenamento das informações não está sendo realizado de maneira correta ou da maneira esperada pelos gestores.

A questão 04 do questionário teve a intenção de verificar se o conhecimento gerado está se tornando explícito ou armazenado

Para isso a seguinte afirmação foi formulada:

- O conhecimento gerado no Programa é armazenado de alguma forma

Os entrevistados concordaram ou não com essa afirmação, em grau que variava de zero para índice “discordo” e dez para índice “concordo”.

As respostas obtidas podem ser vistas na figura 6.6. 


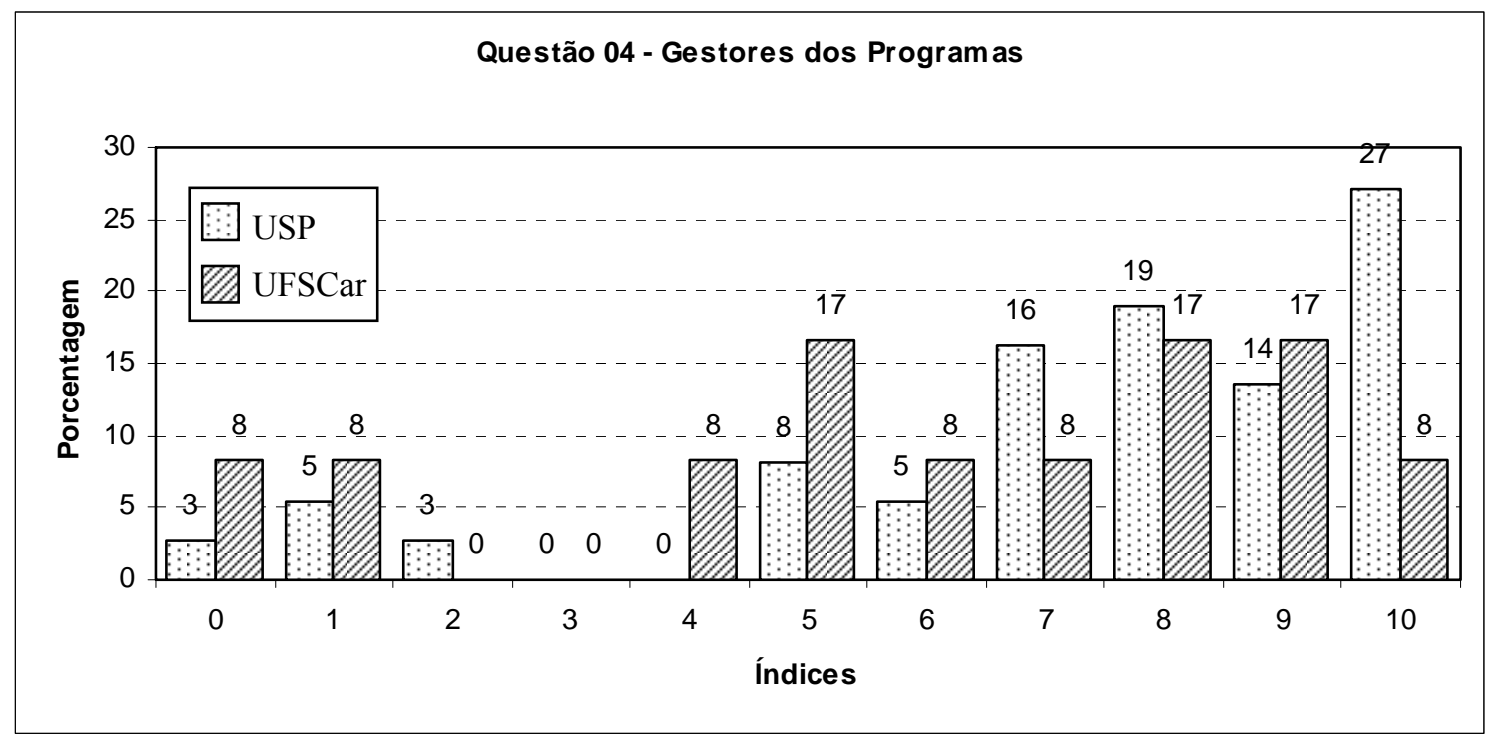

Figura 6.6: Respostas para questão 04 do questionário dos gestores.

Em relação ao armazenamento do conhecimento gerado no Programa, 27\% dos gestores da USP disseram que ocorre sempre, $49 \%$ dos gestores acreditam que quase sempre o conhecimento gerado é armazenado, $14 \%$ acreditam que esse armazenamento é feito de maneira moderada e $11 \%$ crêem que nunca ou quase nunca o armazenamento é efetivado.

Já na UFSCar, $8 \%$ dos gestores acreditam que o armazenamento do conhecimento gerado nos programas ocorre sempre, $42 \%$ acreditam que quase sempre o armazenamento é feito, $33 \%$ que é feito de maneira moderada e $16 \%$ que nunca ou quase nunca o armazenamento é concretizado.

Encontra-se, de acordo com os gestores, uma melhor situação em relação ao armazenamento do conhecimento gerado melhor no Programa da USP.

A armazenagem do conhecimento é importante, pois pode evitar que caminhos já explorados possam ser novamente explorados, ocasionando perda de tempo e duplicidade de resultados, contribuindo para a agilidade da empresa ou instituição. 
A questão 05 do questionário teve a intenção de verificar se o conhecimento é difundido.

Para isso a seguinte afirmação foi formulada:

- O conhecimento gerado é difundido aos envolvidos nos Programas

Os entrevistados concordaram ou não com essa afirmação, em grau que variava de zero para índice “discordo” e dez para índice "concordo”.

As respostas obtidas podem ser vistas na figura 6.7.

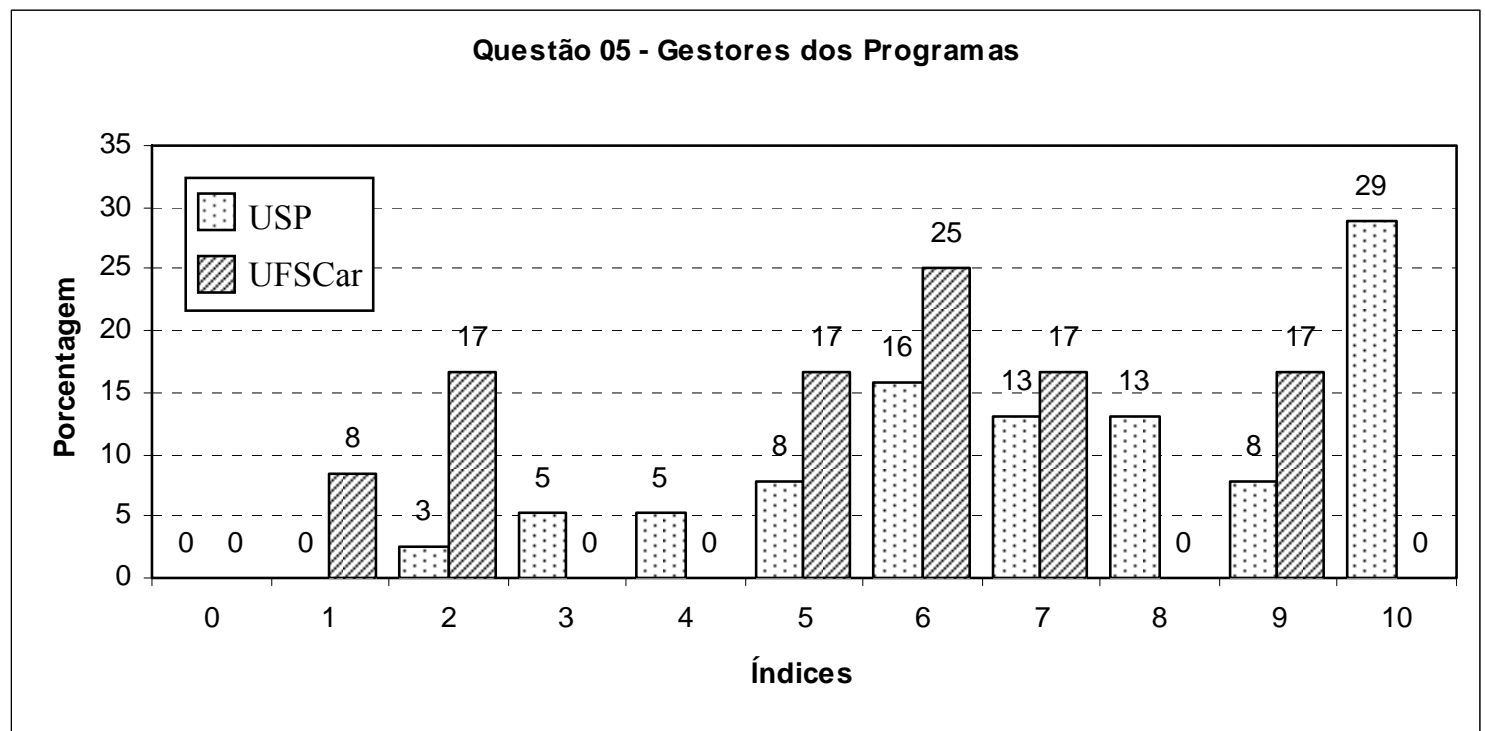

Figura 6.7: Respostas para questão 05 do questionário dos gestores.

Na USP, 29\% dos gestores afirmaram que o conhecimento gerado é sempre difundido aos envolvidos no Programa, 34\% disseram que quase sempre é difundido, $29 \%$ acharam a difusão moderada e, somente, $8 \%$ acreditam que a difusão quase nunca é realizada.

Já na UFSCar, 33\% dos gestores afirmaram que o conhecimento gerado é quase sempre difundido aos envolvidos no Programa, 42\% acharam a difusão moderada e $25 \%$ acreditam que a difusão quase nunca é realizada. 
A difusão ou distribuição do conhecimento é extremamente importante, pois nivela o conhecimento na organização. Na UFSCar, de acordo com os gestores, a difusão tem suas debilidades, pois cerca de $25 \%$ acham que a difusão é falha.

A questão 06 do questionário teve a intenção de verificar se o conhecimento está sendo aplicado.

Para isso a seguinte afirmação foi formulada:

- O conhecimento gerado pelo Programa é aplicado neste

Os entrevistados concordaram ou não com essa afirmação, em grau que variava de zero para índice "discordo" e dez para índice "concordo”.

As respostas obtidas podem ser vistas na figura 6.8.

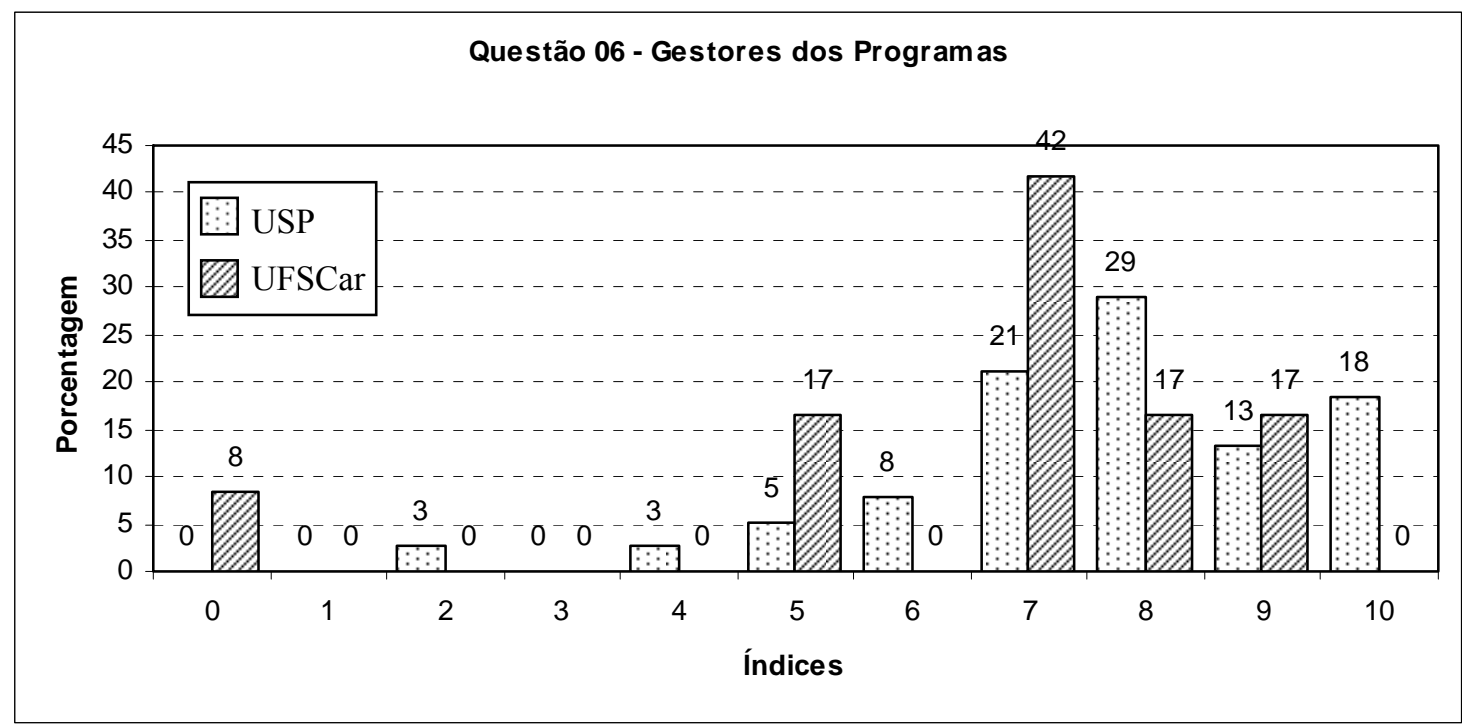

Figura 6.8: Respostas para questão 06 do questionário dos gestores.

De acordo com os gestores do programa da USP, para $18 \%$ o conhecimento gerado pelo Programa é aplicado neste, para 63\% o programa quase sempre aplica o conhecimento, para $16 \%$ o conhecimento é aplicado de forma moderada e, somente, $3 \%$ acreditam que quase nunca o conhecimento gerado é aplicado. 
De acordo com os dados referentes aos gestores do Programa da UFSCar, para $75 \%$ deles o Programa quase sempre aplica os conhecimentos gerados, $17 \%$ acreditam que o conhecimento é aplicado de forma moderada e $8 \%$ acham que nunca o conhecimento é aplicado.

Embora na UFSCar 8\% dos gestores acredita que o conhecimento gerado nunca é aplicado, o cenário é muito bom em ambos os Programas quanto a aplicação do conhecimento gerado. Isso significa que além da criação dos conceitos ou novos conhecimentos, esses estão sendo implementados, e que o conhecimento está sendo aplicado.

A questão 07 do questionário teve a intenção de verificar se o conhecimento está sendo aplicado.

Para isso a seguinte afirmação foi formulada:

- Contribuo com a coleta seletiva do Programa separando os materiais na Universidade

Os entrevistados concordaram ou não com essa afirmação, em grau que variava de zero para índice "nunca” e dez para índice "sempre”.

As respostas obtidas podem ser vistas na figura 6.9. 


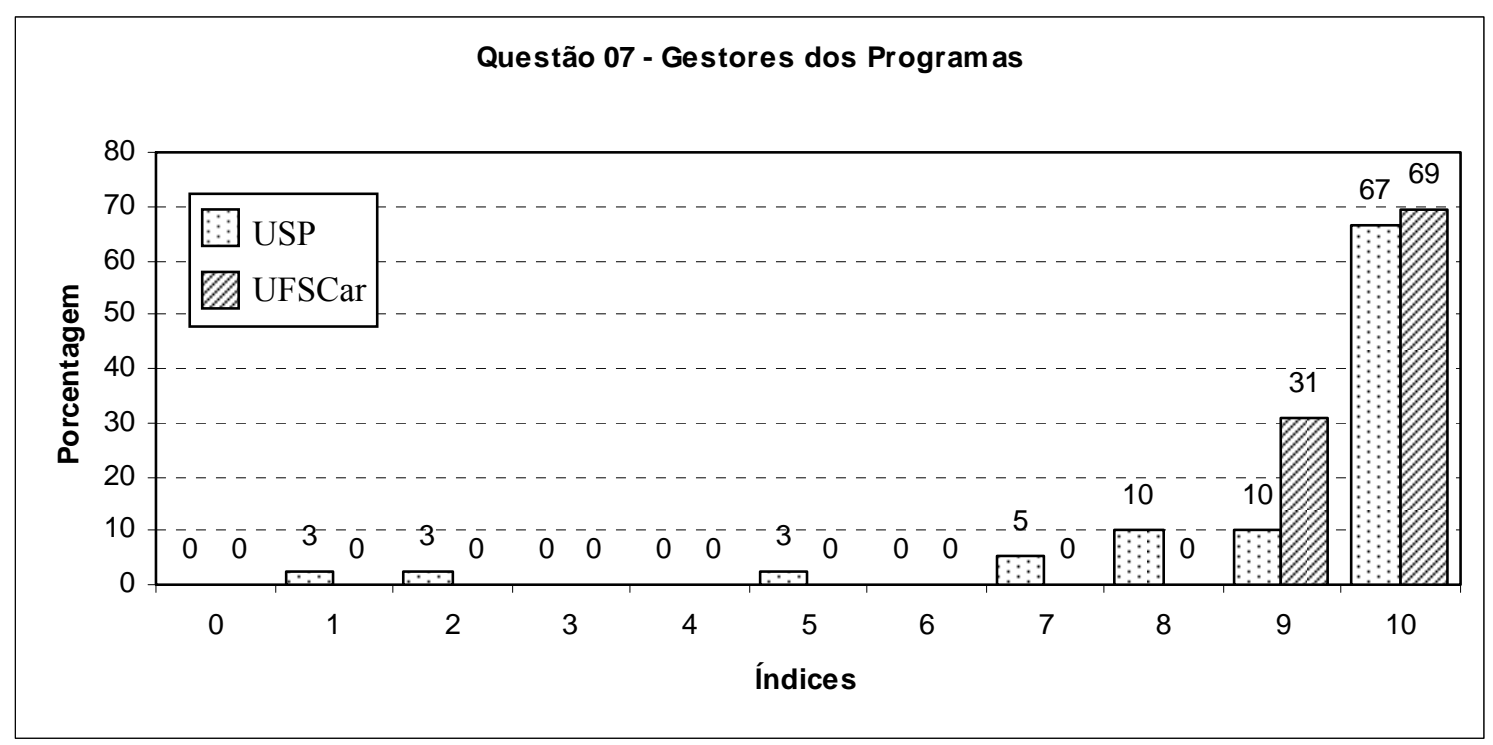

Figura 6.9: Respostas para questão 07 do questionário dos gestores.

De acordo com os dados obtidos se observa que $67 \%$ dos gestores do Programa da USP sempre contribuem com a coleta seletiva, 26\% quase sempre contribuem e, somente, $8 \%$ contribuem de maneira moderada ou quase nunca contribuem.

Na UFSCar, 69\% dos gestores sempre contribuem com a coleta seletiva, e o restante, $31 \%$ quase sempre contribuem.

De posse desses dados, se observa um grande comprometimento dos gestores com a coleta seletiva dos materiais, que embora seja a última alternativa da hierarquia da filosofia 3R's da Logística Reversa, não deixa de ser um grande passo para a diminuição da quantidade de lixo enviada aos aterros e lixões. Esse resultado também mostra que o conhecimento aprendido está sendo aplicado.

A questão 08 do questionário teve a intenção de verificar se o conhecimento está sendo aplicado.

Para isso a seguinte afirmação foi formulada:

- Aplico o conhecimento aprendido com o Programa fora da Universidade 
Os entrevistados concordaram ou não com essa afirmação, em grau que variava de zero para índice “nunca” e dez para índice "sempre”.

As respostas obtidas podem ser vistas na figura 6.10.

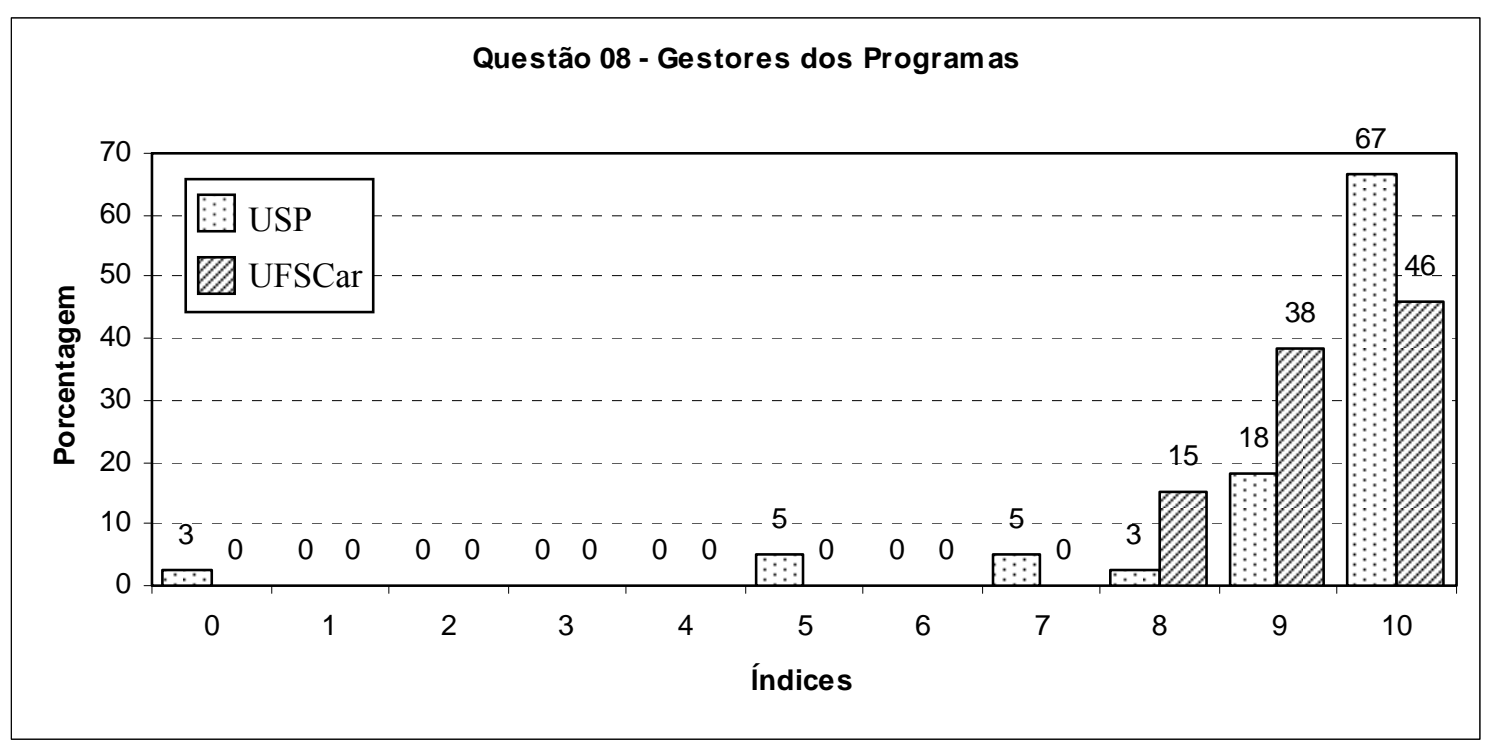

Figura 6.10: Respostas para questão 08 do questionário dos gestores.

Para os gestores da USP, $67 \%$ sempre aplicam o conhecimento aprendido com o programa fora da Universidade, $26 \%$ quase sempre aplicam e $8 \%$ aplicam de forma moderada ou nunca aplicam.

Os gestores da UFSCar têm comportamento diferente, 46\% sempre aplicam o conhecimento aprendido com o programa fora da Universidade e 54\% quase sempre aplicam.

Isso mostra que o conhecimento aprendido com os Programas não fica restrito ao ambiente universitário, esse conhecimento é aplicado em ambientes externos aos dos Programas e mostra que o objetivo educacional dos Programas é cumprido.

A questão 09 do questionário teve a intenção de verificar se o conhecimento tácito é externalizado ou compartilhado. 
Para isso a seguinte afirmação foi formulada:

- Participo com sugestões/críticas para a melhoria do Programa

Os entrevistados concordaram ou não com essa afirmação, em grau que variava de zero para índice “nunca” e dez para índice "sempre”.

As respostas obtidas podem ser vistas na figura 6.11 .

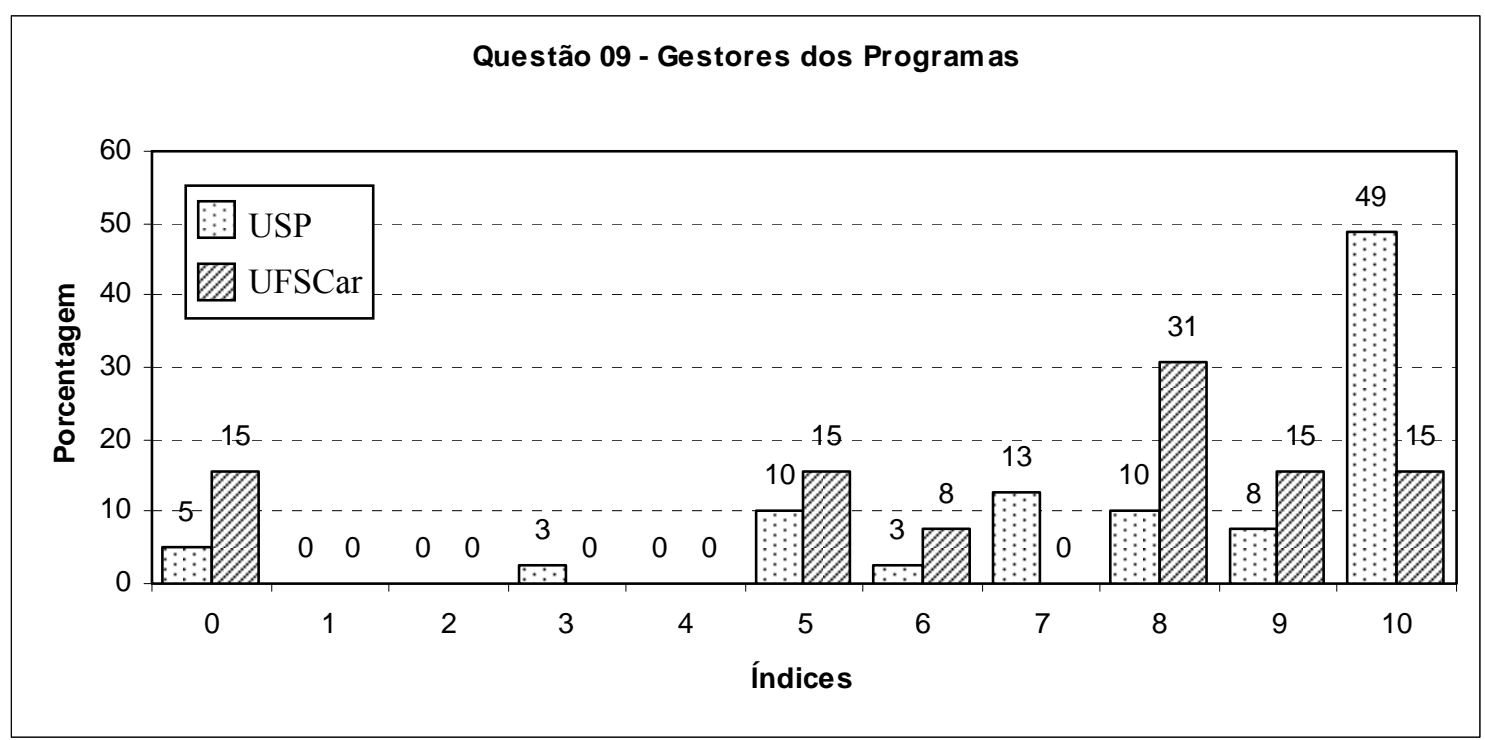

Figura 6.11: Respostas para questão 09 do questionário dos gestores.

Em relação à participação com sugestões e/ou críticas para a melhoria do Programa, os gestores da USP tem a seguinte característica: 49\% sempre participam com sugestões e/ou críticas, $31 \%$ quase sempre participam, $13 \%$ participam moderadamente e $8 \%$ quase nunca ou nunca participam.

Já dos gestores da UFSCar, 15\% sempre participam com sugestões e/ou críticas, $46 \%$ quase sempre participam, $23 \%$ participam de forma moderada e $15 \%$ nunca participam.

Embora o cenário geral esteja aceitável, seria interessante aumentar, principalmente na UFSCar, a participação dos gestores nas sugestões ou críticas aos 
Programas, pois essa questão reflete a externalização do conhecimento. Caso a externalização não se concretize, uma etapa da criação de conhecimento é quebrada e o modelo de espiral do conhecimento é quebrado. Além disso, caso a externalização não ocorra, o compartilhamento do conhecimento fica debilitado, tornando sua criação muito mais difícil e penosa para as instituições.

A questão 10 do questionário teve a intenção de verificar se o conhecimento tácito é externalizado ou compartilhado.

Para isso a seguinte afirmação foi formulada:

- Minhas sugestões/críticas são ouvidas pelos superiores dentro Programa

Os entrevistados concordaram ou não com essa afirmação, em grau que variava de zero para índice "nunca” e dez para índice "sempre”.

As respostas obtidas podem ser vistas na figura 6.12 .

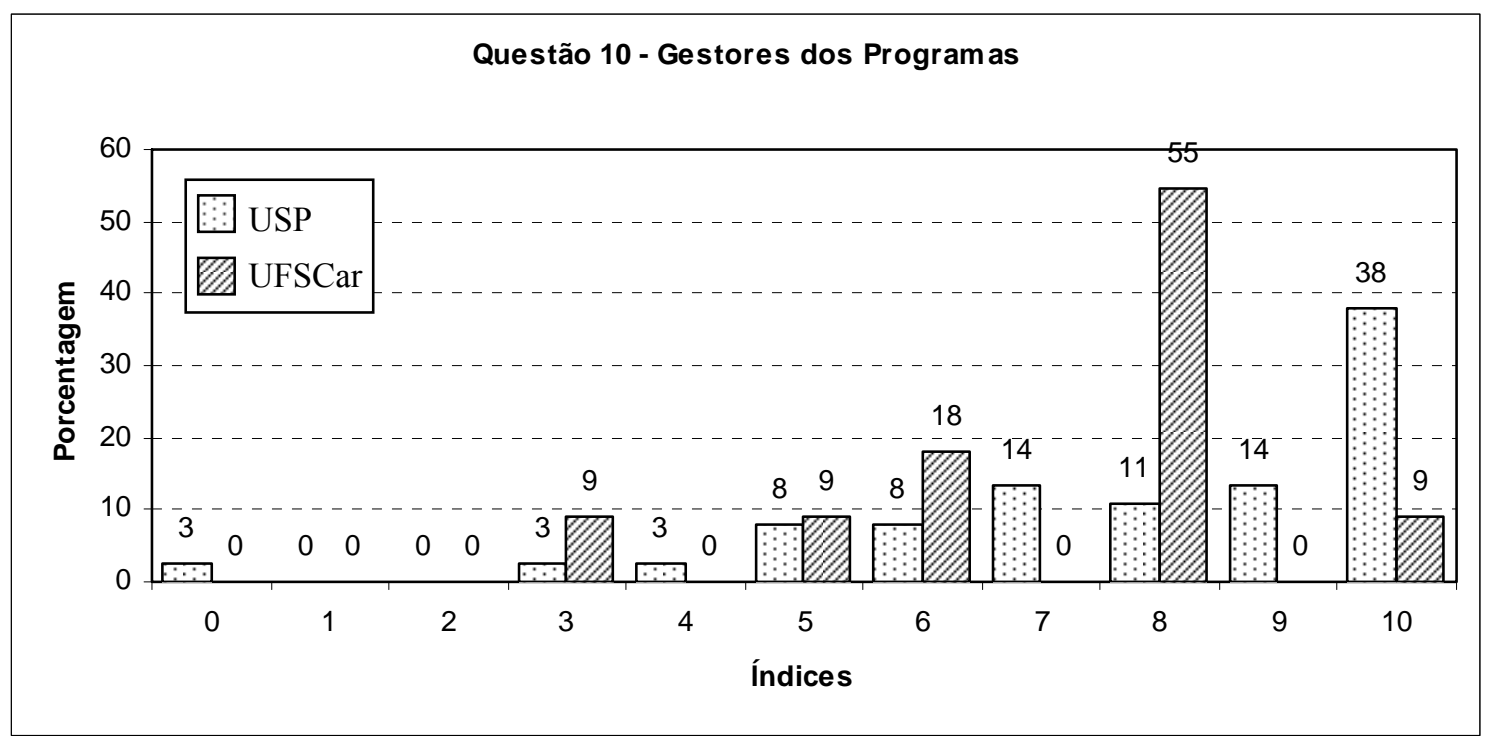

Figura 6.12: Respostas para questão 10 do questionário dos gestores. 
É importante frisar que os entrevistados que responderam "não" para a pergunta anterior, questão 09 , não responderam essa questão, pois não conseguiriam opinar se elas são ouvidas ou não.

De acordo com os dados, na USP, $38 \%$ dos gestores sempre têm suas sugestões e/ou críticas ouvidas pelos superiores dentro do Programa, outros $38 \%$ quase sempre tem suas críticas e/ou sugestões ouvidas, 19\% acham que suas críticas e/ou sugestões são ouvidas de maneira moderada e $6 \%$ que nunca ou quase nunca tem suas sugestões e/ou críticas ouvidas.

Na UFSCar, 9\% dos gestores sempre têm suas sugestões e/ou críticas ouvidas pelos superiores dentro do Programa, 55\% quase sempre tem suas críticas e/ou sugestões ouvidas, $27 \%$ acham que suas críticas e/ou sugestões são ouvidas de maneira moderada e $9 \%$ que quase nunca tem suas sugestões e/ou críticas ouvidas.

Ter as críticas e/ou sugestões ouvidas pelo Programa é de grande importância para a combinação do conhecimento, pois o mesmo pode ser externalizado e não aproveitado. A partir do momento em que as sugestões e/ou críticas são ouvidas, o conhecimento se combina e se criam novos conhecimentos, dando seguimento a espiral do conhecimento já apresentada.

A etapa da combinação do conhecimento é tão importante como as outras etapas da espiral do conhecimento (socialização, externalização, internalização) assim, não é conveniente haver para perda de conhecimento, e o recomendado seria que o canal para se ouvir sugestões e/ou críticas fosse melhorado para os gestores, uma vez que a quantidade relativa a índice inferior a seis (6) ser considerável. 
A questão 11 do questionário teve a intenção de verificar se o ambiente é favorável a externalização e compartilhamento do conhecimento.

Para isso a seguinte afirmação foi formulada:

- Fico a vontade em fazer sugestões/críticas sobre o Programa

Os entrevistados concordaram ou não com essa afirmação, em grau que variava de zero para índice "nunca” e dez para índice "sempre”.

As respostas obtidas podem ser vistas na figura 6.13.

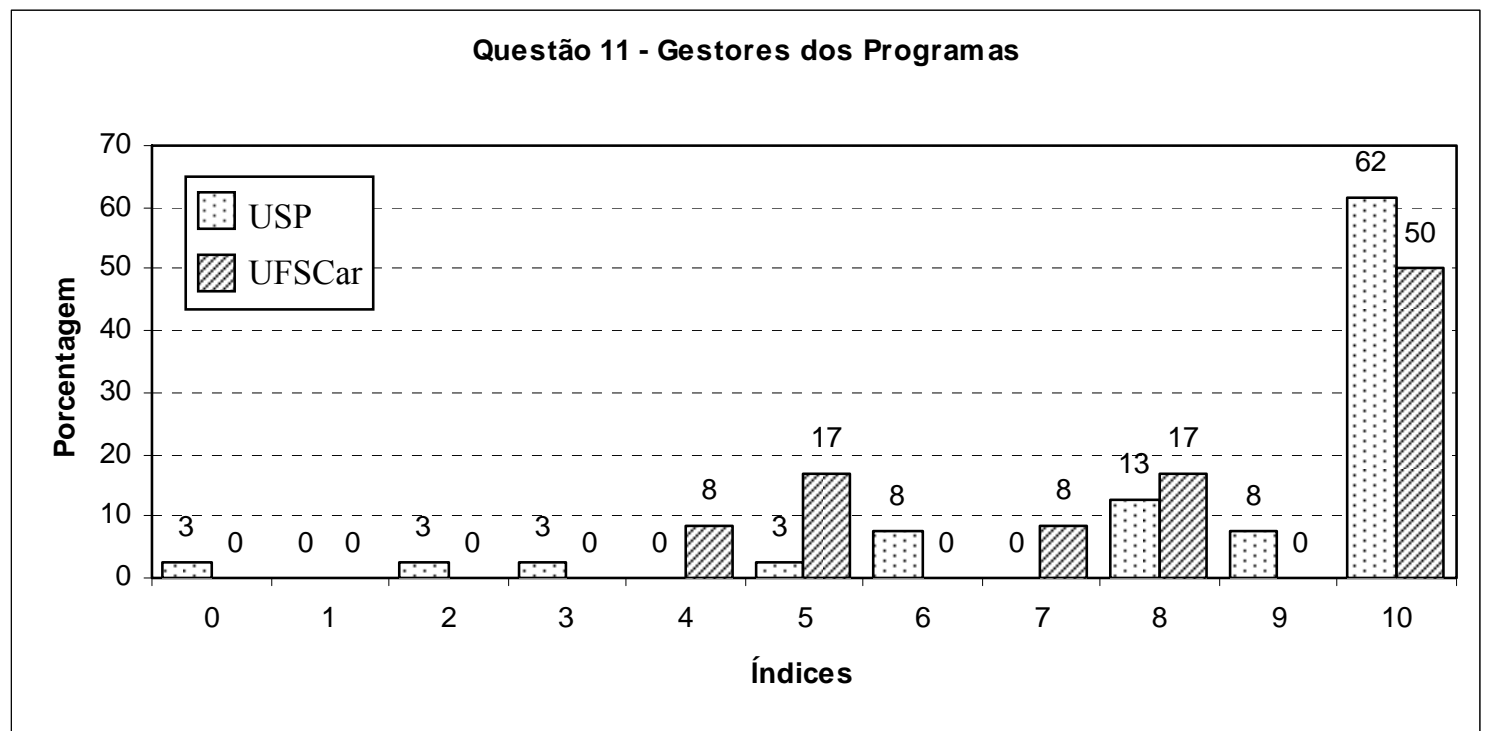

Figura 6.13: Respostas para questão 11 do questionário dos gestores.

$\mathrm{Na}$ USP, $62 \%$ dos gestores sempre ficam a vontade em fazer sugestões e/ou críticas ao programa, $21 \%$ quase sempre ficam a vontade, $10 \%$ classificaram a vontade como moderada e $8 \%$ nunca ou quase nunca se sentem a vontade.

Na UFSCar, $50 \%$ dos gestores sempre ficam a vontade em fazer sugestões e/ou críticas ao programa, $25 \%$ quase sempre ficam a vontade e outros $25 \%$ classificaram a vontade como moderada. 
Com isso pode-se dizer que o ambiente é favorável a externalização e compartilhamento do conhecimento, embora algumas medidas de socialização possam ser tomadas para que o sentimento de timidez em fazer sugestões e/ou críticas diminua ainda mais, colaborando com a criação de novos conhecimentos.

A questão 12 do questionário teve a intenção de verificar se a pessoa está satisfeita com a função exercida no Programa.

Para isso a seguinte afirmação foi formulada:

- Estou satisfeito com minha função no Programa

Os entrevistados concordaram ou não com essa afirmação respondendo sim ou não.

As respostas obtidas podem ser vistas na figura 6.14 .

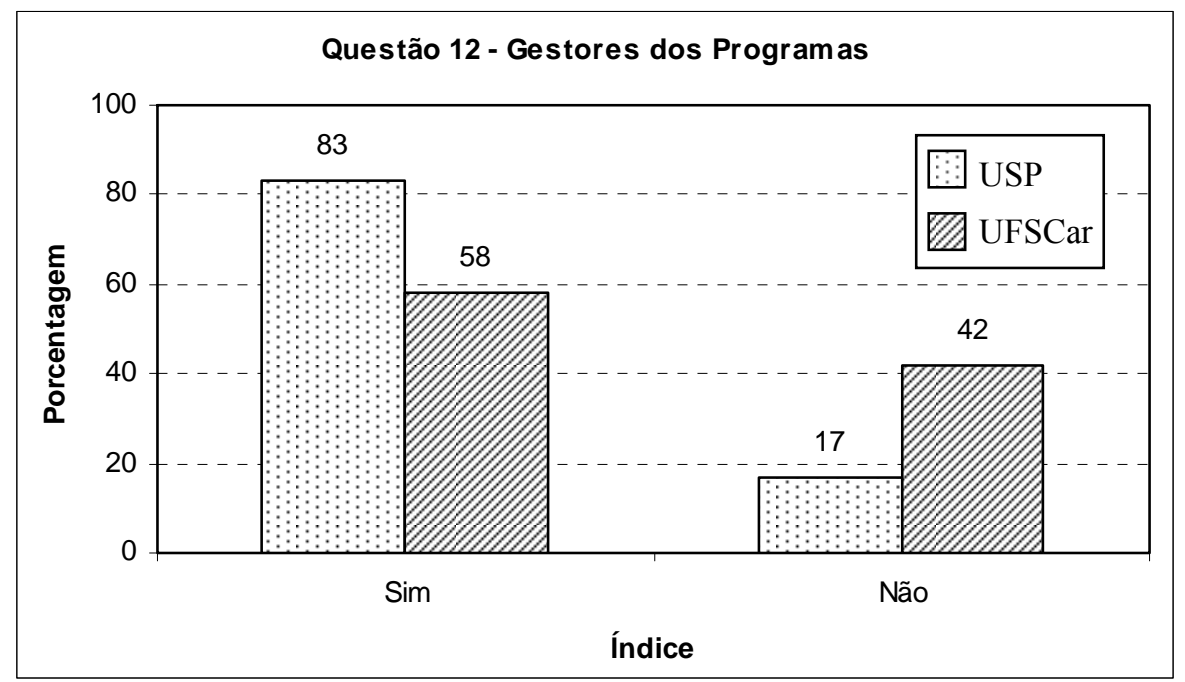

Figura 6.14: Respostas para questão 12 do questionário dos gestores.

Na USP, $83 \%$ dos gestores estão satisfeitos com a função no Programa e 17\% não estão satisfeitos. Na UFSCar, 58\% dos gestores estão satisfeitos com a função no Programa e $42 \%$ não estão satisfeitos. 
Esses dados são importantes, pois revelam certa insatisfação dos gestores da UFSCar com a função no programa, o que pode comprometer o programa ou criar condições desfavoráveis para sua evolução. O que foi observado é que alguns gestores são nomeados, mas não são comunicados da nomeação, ou seja, não existe uma seleção para identificar os gestores realmente interessados em participar do programa.

A questão 13 do questionário teve a intenção de verificar se ocorrem mudanças na gestão dos Programas.

Para isso a seguinte afirmação foi formulada:

- Ocorre mudança de gestão dos Programas

Os entrevistados concordaram ou não com essa afirmação, em grau que variava de zero para índice "nunca” e dez para índice "sempre”.

As respostas obtidas podem ser vistas na figura 6.15 .

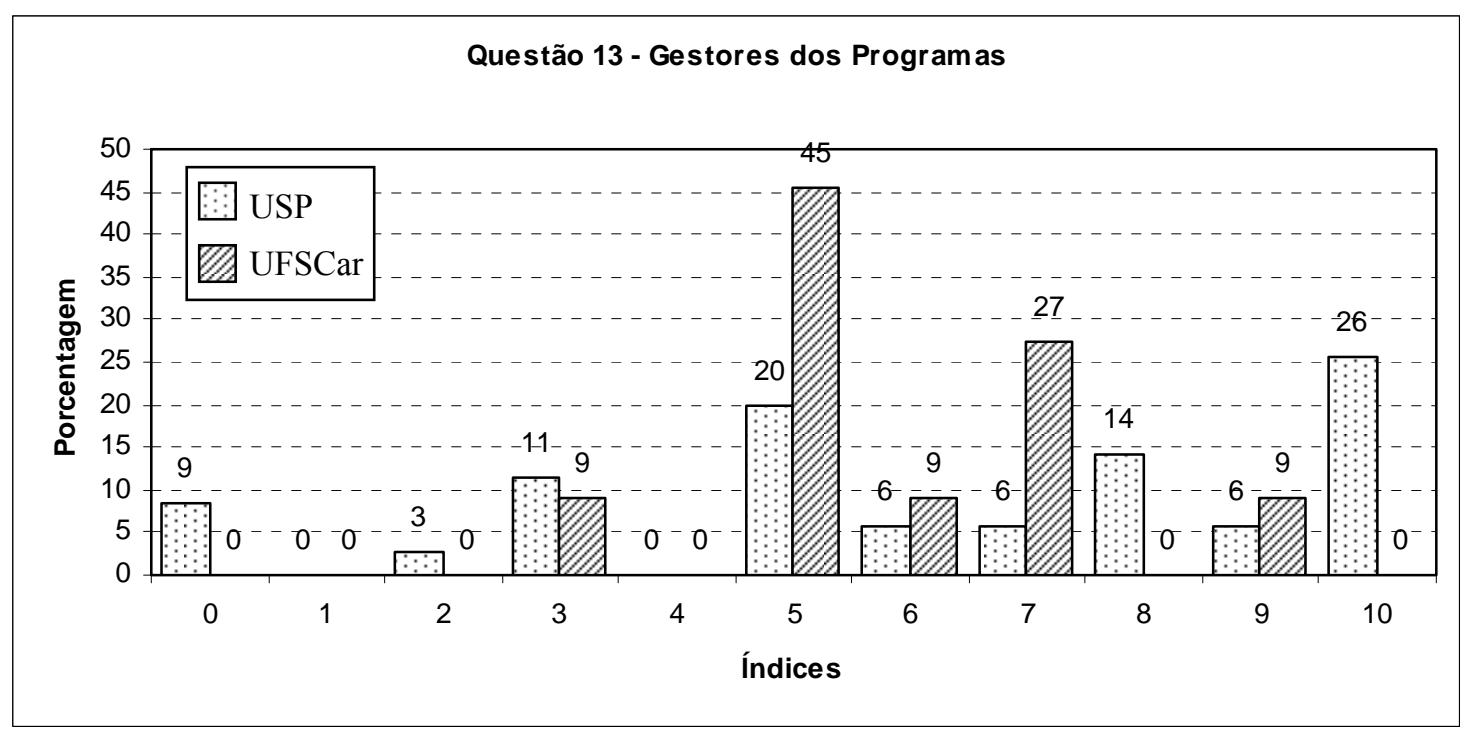

Figura 6.15: Respostas para questão 13 do questionário dos gestores.

$\mathrm{Na}$ USP, os gestores tiveram opinião bem dividida, 26\% acham que sempre ocorrem mudanças na gestão do Programa. O mesmo número foi observado para os 
gestores que acham que quase sempre ocorrem mudanças e para os que acham que as mudanças são feitas de forma moderada. Já 14\% acreditam que as mudanças quase nunca acontecem e $9 \%$ que nunca acontecem.

$\mathrm{Na}$ UFSCar se encontra um quadro um pouco diferente, onde $36 \%$ crêem que quase sempre ocorrem mudanças na gestão, $55 \%$ que essas mudanças são moderadas e $9 \%$ que quase nunca ocorrem.

A mudança na gestão é importante para que novos rumos, antes não explorados, possam ser tomados pela nova administração e para que problemas antes não identificados possam ser identificados pelos nos gestores. Tanto na USP quanto na UFSCar a mudança da gestão dos programas deveria ser mais acentuada.

A questão 14 do questionário teve a intenção de verificar a adesão com a iniciativa dos programas.

Para isso a seguinte afirmação foi formulada:

- Em relação às iniciativas tomadas pelo Programa

Os entrevistados concordaram ou não com essa afirmação, em grau que variava de zero para índice “discordo” e dez para índice “concordo”.

As respostas obtidas podem ser vistas na figura 6.16. 


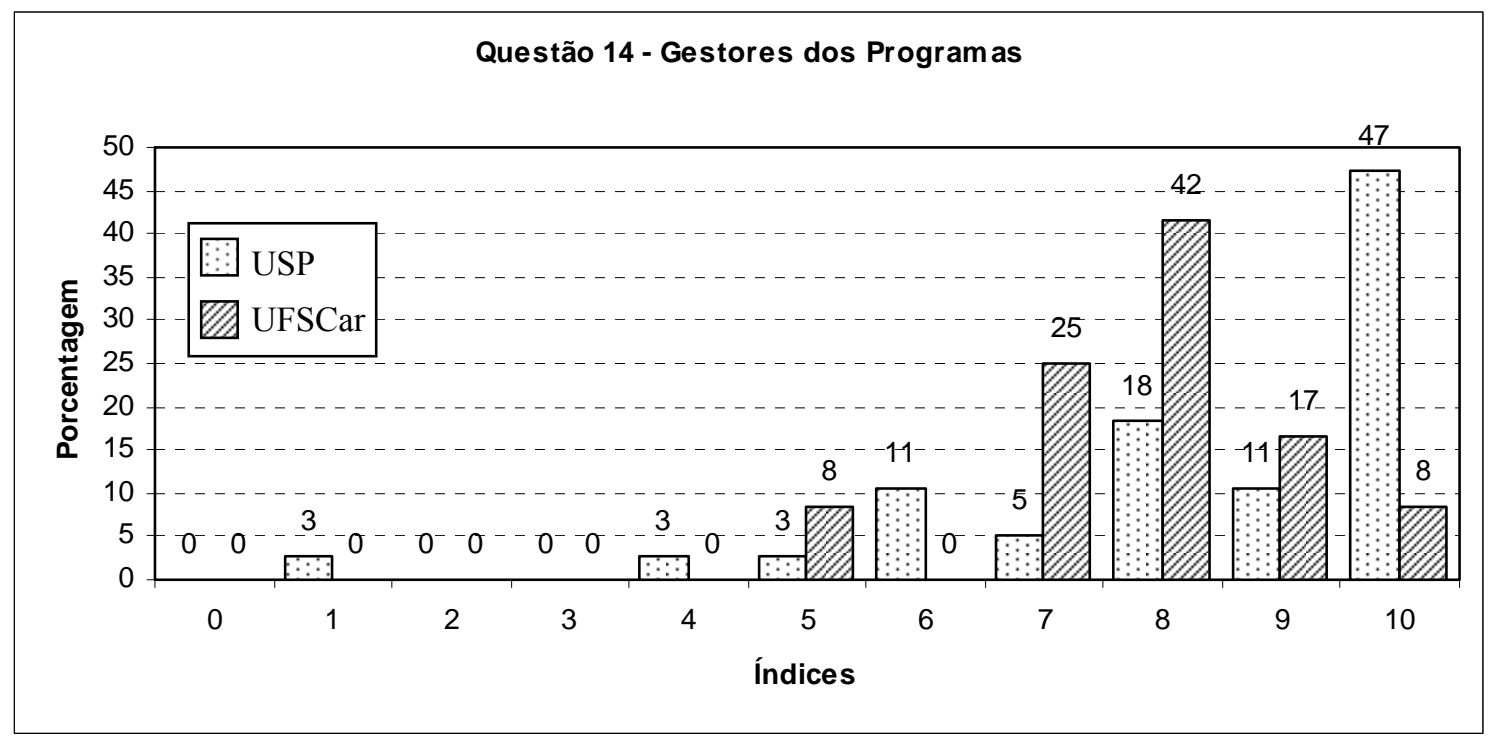

Figura 6.16: Respostas para questão 14 do questionário dos gestores.

Na USP $47 \%$ dos gestores sempre concordam com as iniciativas tomadas pelo Programa, $34 \%$ quase sempre concordam, $16 \%$ concordam de forma moderada e 3\% quase nunca concordam.

Já na UFSCar, $8 \%$ dos gestores sempre concordam com as iniciativas tomadas pelo Programa, $83 \%$ quase sempre concordam e $8 \%$ concordam de forma moderada.

O resultado mostra que os gestores estão de acordo com as iniciativas tomadas pelo programa, o que possibilita maior integração e afinidade entre gestores e programas.

A questão 15 do questionário teve a intenção de verificar qual é a participação dos gestores nas palestras e eventos dos Programas.

Para isso a seguinte afirmação foi formulada:

- Participo de palestras e eventos oferecidos pelo Programa

Os entrevistados concordaram ou não com essa afirmação, em grau que variava de zero para índice "nunca” e dez para índice "sempre”. 
As respostas obtidas podem ser vistas na figura 6.17.

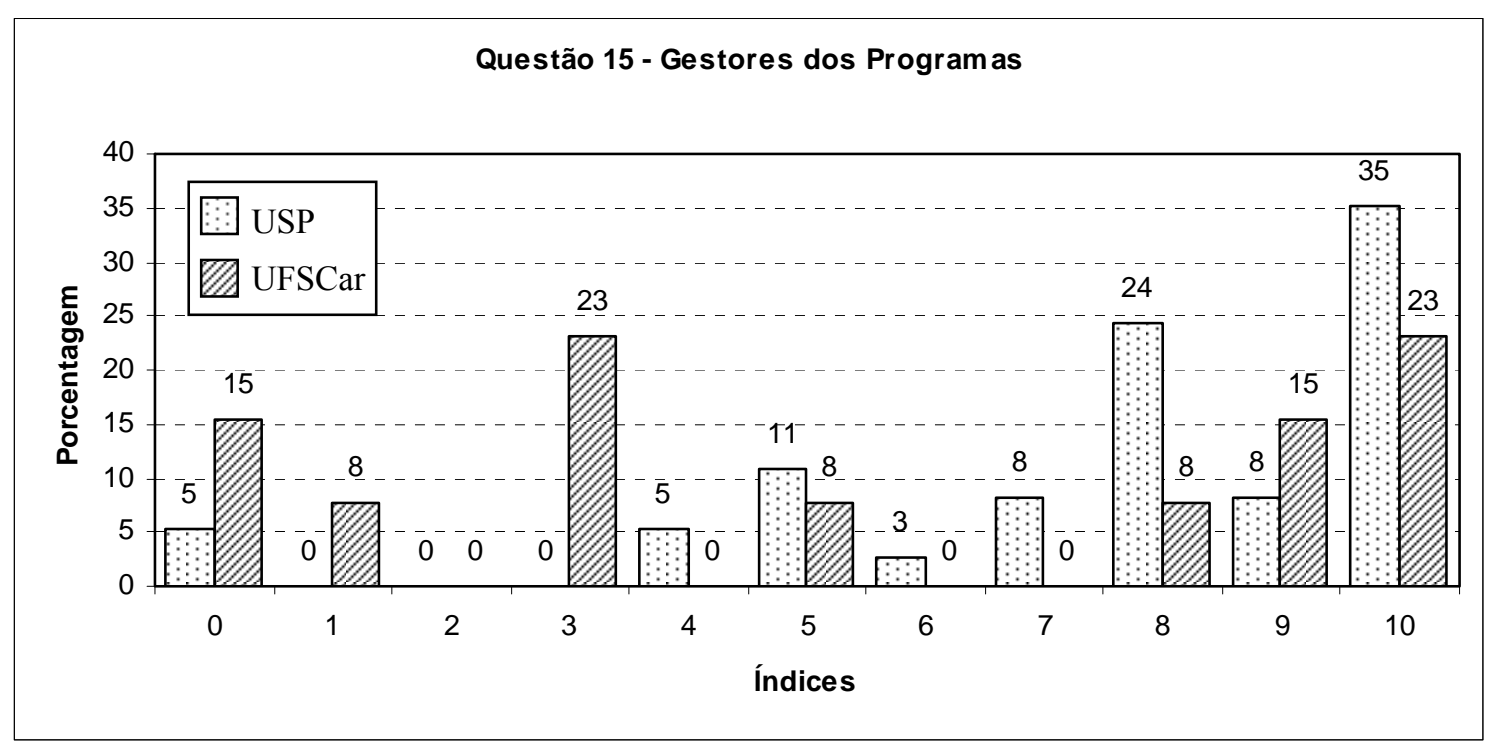

Figura 6.17: Respostas para questão 15 do questionário dos gestores.

De acordo com os gestores da USP, 35\% sempre participam de palestras e eventos do programa, $41 \%$ quase sempre participam dos eventos e palestras, $19 \%$ participam de forma moderada e, somente, $5 \%$ nunca participam.

Já na UFSCar a opinião dos gestores é mais dividida. 23\% crêem que sempre participam de palestras e eventos, outros $23 \%$ quase sempre participam, $8 \%$ acreditam que essa participação é moderada, $31 \%$ quase nunca participam e $15 \%$ nunca participam dos eventos e palestras oferecidos pelos Programas.

Participar de palestras e eventos dos programas é, também, compartilhar o conhecimento com outras pessoas envolvidas pelos programas, por isso é importante que os gestores participem desses tipos de eventos. Como se observa, o programa da UFSCar tem que incentivar seus gestores a terem maior participação nas palestras e eventos oferecidos pelo programa.

A questão 16 do questionário teve a intenção de verificar se os Programas influenciam de alguma forma a relação dos gestores com as questões ambientais. 
Para isso a seguinte afirmação foi formulada:

- O Programa influencia de alguma forma minha relação com as questões ambientais

Os entrevistados concordaram ou não com essa afirmação, em grau que variava de zero para índice "nunca” e dez para índice "sempre”.

As respostas obtidas podem ser vistas na figura 6.18.

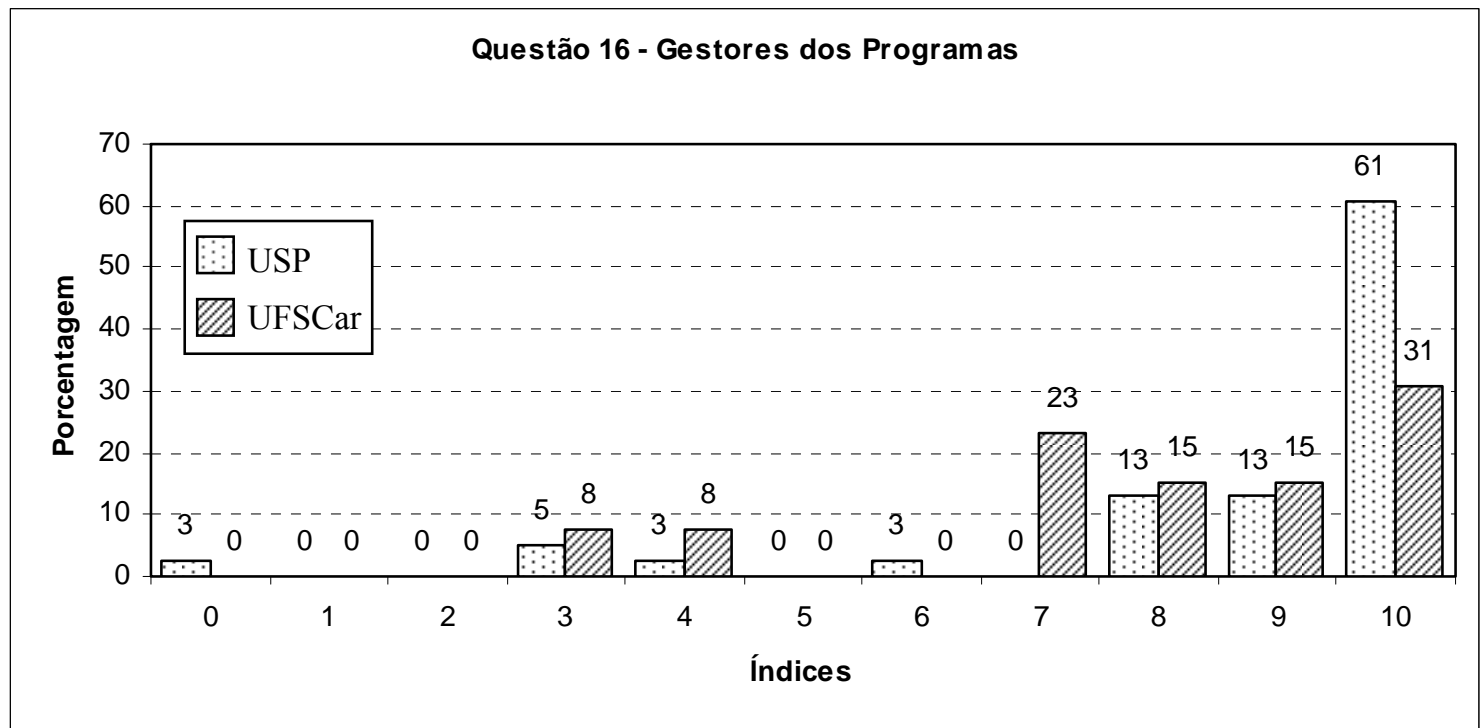

Figura 6.18: Respostas para questão 16 do questionário dos gestores.

De acordo com a pesquisa, para 61\% dos gestores da USP o Programa sempre influencia de alguma forma as relações com as questões ambientais e para $26 \%$ essa influência ocorre quase sempre.

Na UFSCar para 31\% dos gestores o Programa sempre influencia de alguma forma as relações com as questões ambientais e para 54\% essa influência ocorre quase sempre.

Essa questão foi formulada a pedido do programa da USP e mostrou que os programas influenciam seus gestores nas questões ambientais. 
Com a finalidade de avaliar o questionário a seguinte questão foi colocada ao final do mesmo:

- Avalie somente o questionário

As respostas obtidas podem ser vistas na figura 6.19.

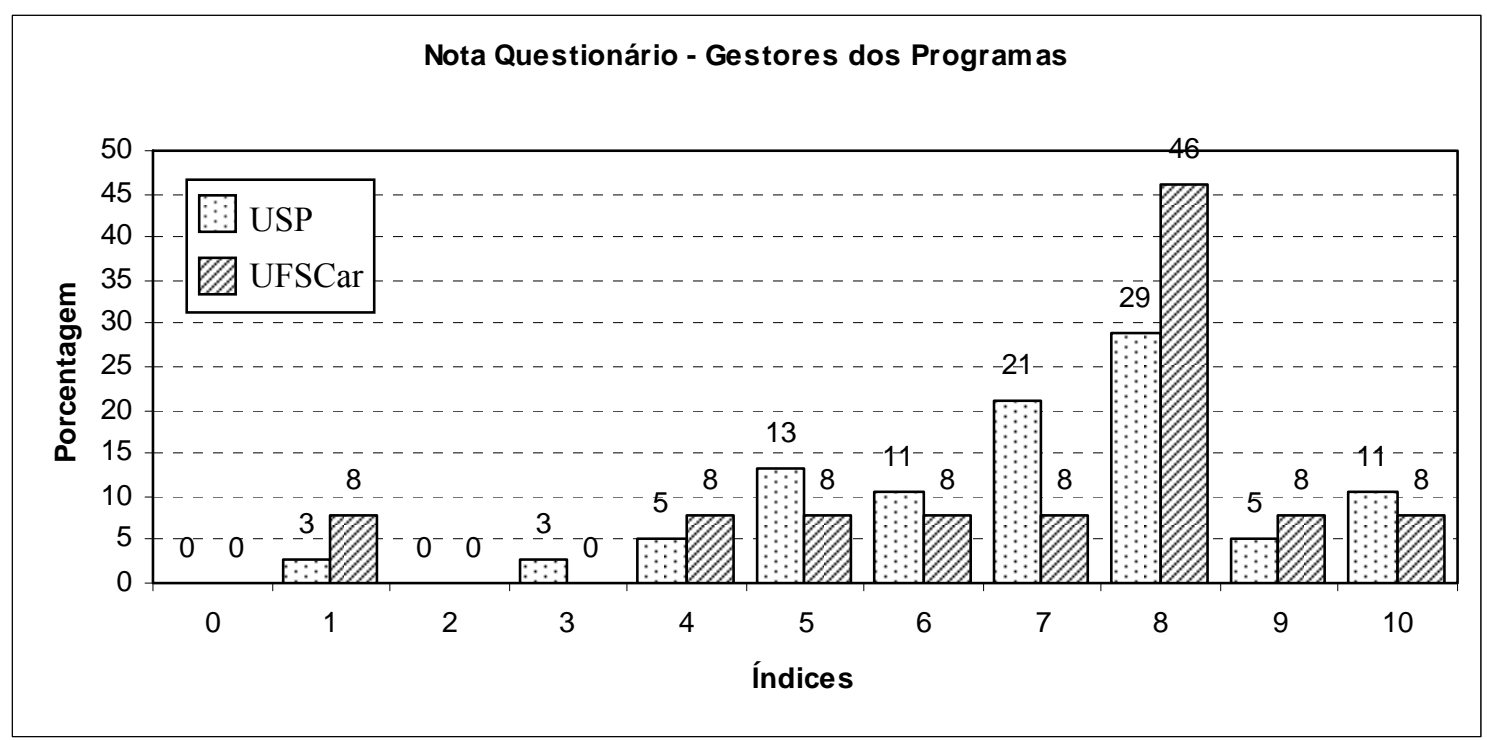

Figura 6.19: Respostas para questão Nota do questionário dos gestores.

Em ambas as Universidades a médias das notas foi de, aproximadamente sete (7), mostrando que o questionário foi bem aceito pelos gestores.

\section{2 - RESULTADOS OBTIDOS PARA O GRUPO DE CLIENTES}

O questionário primeiramente caracterizou os clientes de acordo com o sexo e cargo que ocupam nas instituições. Esses dados são apresentados nas figuras 6.20 e 6.21 


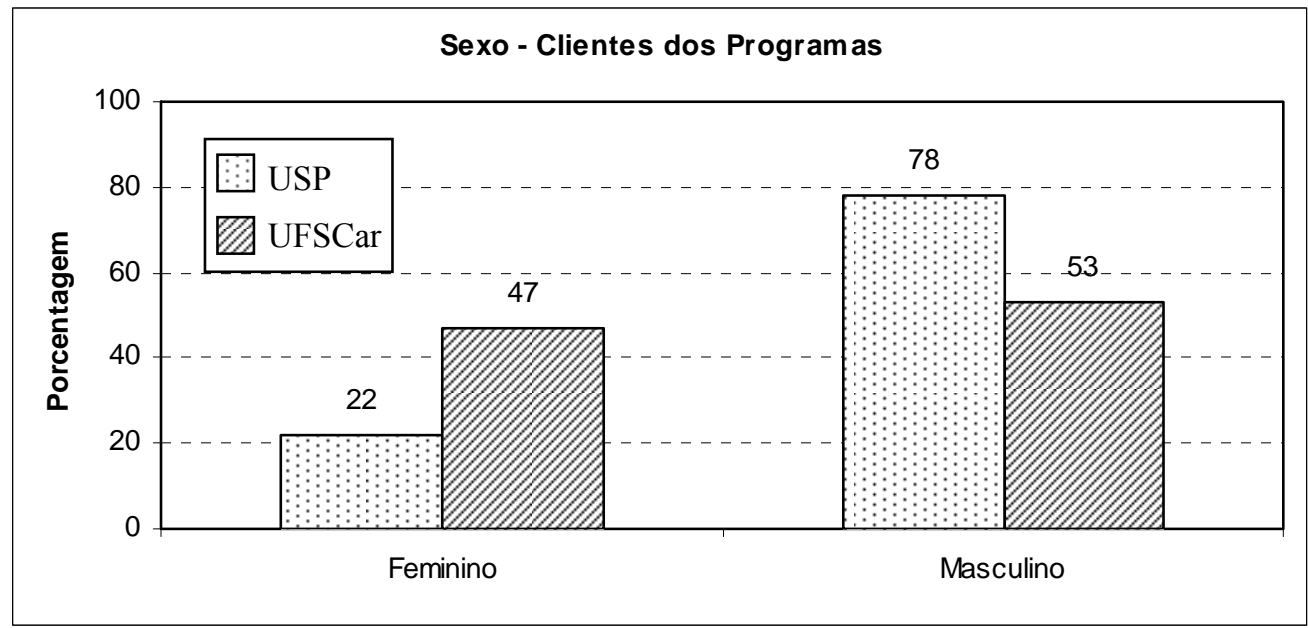

Figura 6.20: Caracterização dos clientes da USP e da UFSCar.

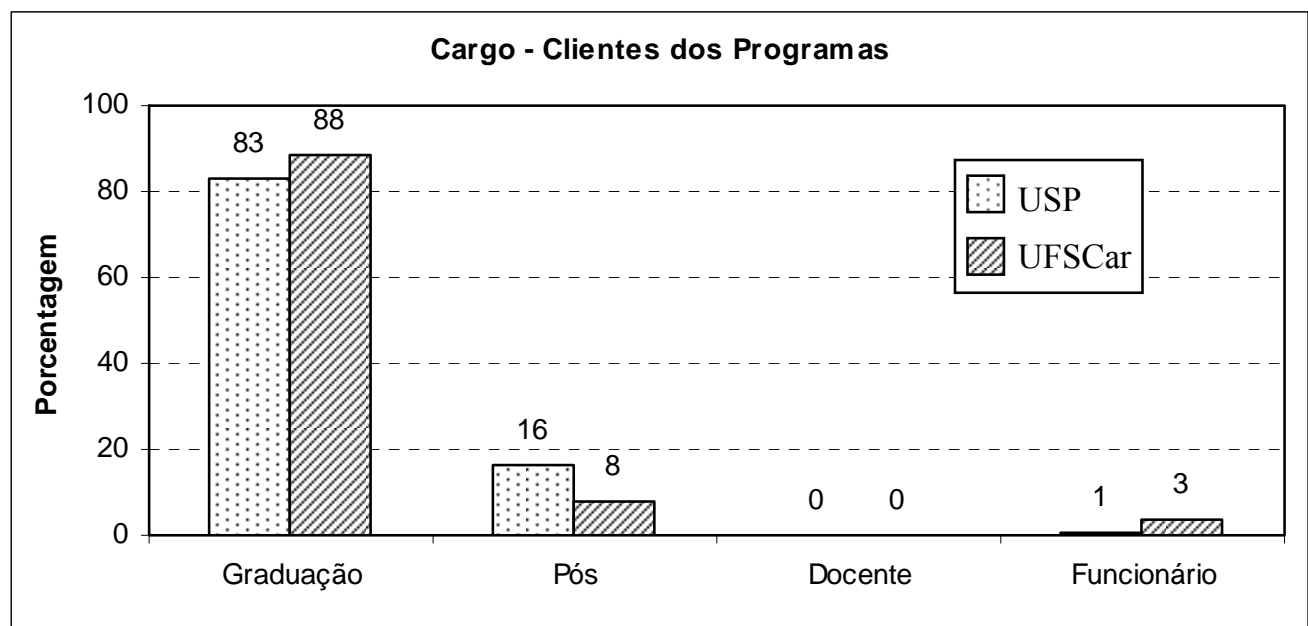

Figura 6.21: Caracterização dos clientes da USP e da UFSCar.

Como se pode notar os programas possuem características um pouco diferentes em relação ao sexo da classe clientes. Na UFSCar a quantidade de mulheres é maior, $47 \%$ do total e na USP as mulheres representam somente $22 \%$ do total de entrevistados. Isso se explica pelo fato de que na UFSCar existem mais cursos nas áreas de Humanas e Biológicas do que na USP, que tem a área de exatas como predominante.

Em relação ao cargo, as Universidades possuem características semelhantes, tendo na USP $83 \%$ de estudantes de graduação, $16 \%$ de estudantes de pós-graduação e $1 \%$ de funcionários e na UFSCar $88 \%$ de estudantes de graduação, $8 \%$ de estudantes de pós-graduação e 3\% de funcionários. 
Não se observa a presença de docentes na amostra pesquisada, o que já era esperado, pois o ambiente dos RU's é muito pouco freqüentado pelos mesmos.

Após isso a análise das questões do questionário será feita individualmente, questão por questão. Cada questão terá seu intuito e um gráfico que mostrará os índices de respostas obtidos e, posteriormente, uma análise dos resultados obtidos que podem ser em conjunto com outras questões complementares, como feito para os gestores.

A questão 01 do questionário teve a intenção de verificar se o entrevistado conhecia o Programa. Para isso a seguinte afirmação foi formulada:

- Conheço o Programa

Os entrevistados concordaram ou não com essa afirmação respondendo sim ou não.

As respostas obtidas podem ser vistas na figura 6.22.

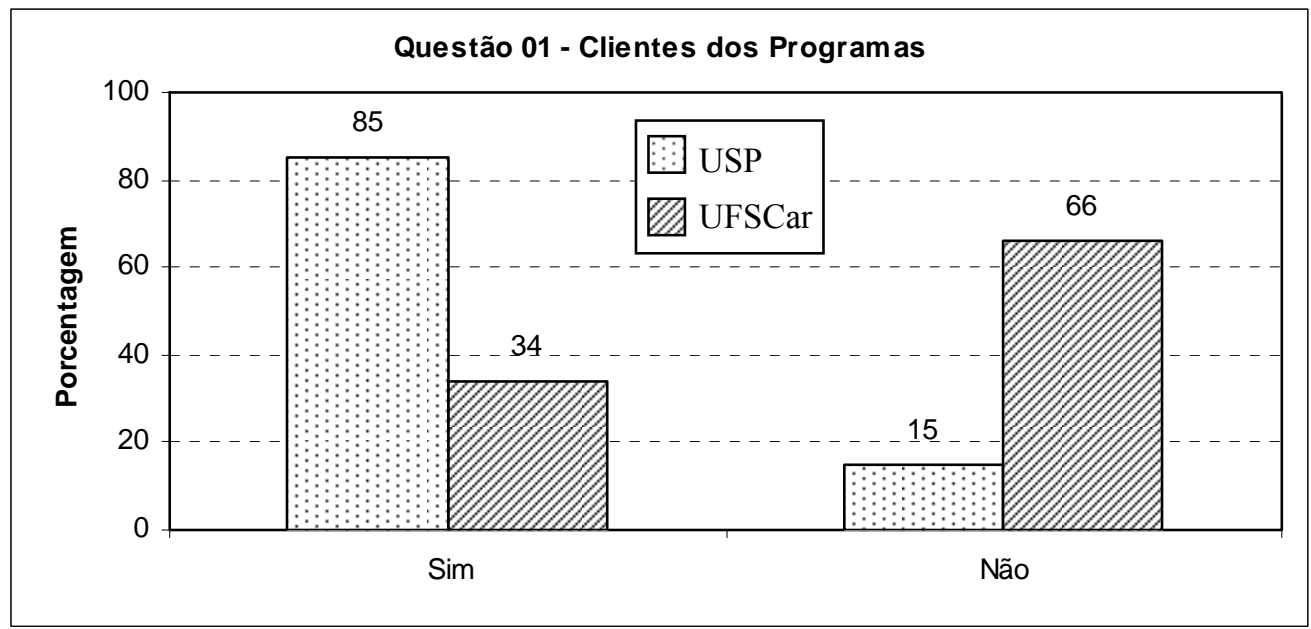

Figura 6.22: Respostas para questão 01 do questionário dos clientes.

É importante frisar que os entrevistados que responderam "não" para essa primeira questão não responderam o restante do questionário, pois uma pessoa que não conhece o Programa não tem condições de fornecer dados sobre o mesmo. 
De posse dos dados pode-se notar uma grande diferença nos dados entre os Programas da USP e UFSCar. Enquanto na USP 85\% dos entrevistados conhecem o programa, na UFSCar esse número cai para somente 34\%.

Isso mostra que o programa da UFSCar é pouco conhecido pelos alunos do campus, provavelmente pela falta de divulgação.

A questão 02 do questionário teve a intenção de verificar se o conhecimento é difundido. Para isso a seguinte afirmação foi formulada:

- O Programa oferece cursos de aprendizado à comunidade do Campus

Os entrevistados concordaram ou não com essa afirmação, em grau que variava de zero para índice “nunca” e dez para índice "sempre”.

As respostas obtidas podem ser vistas na figura 6.23.

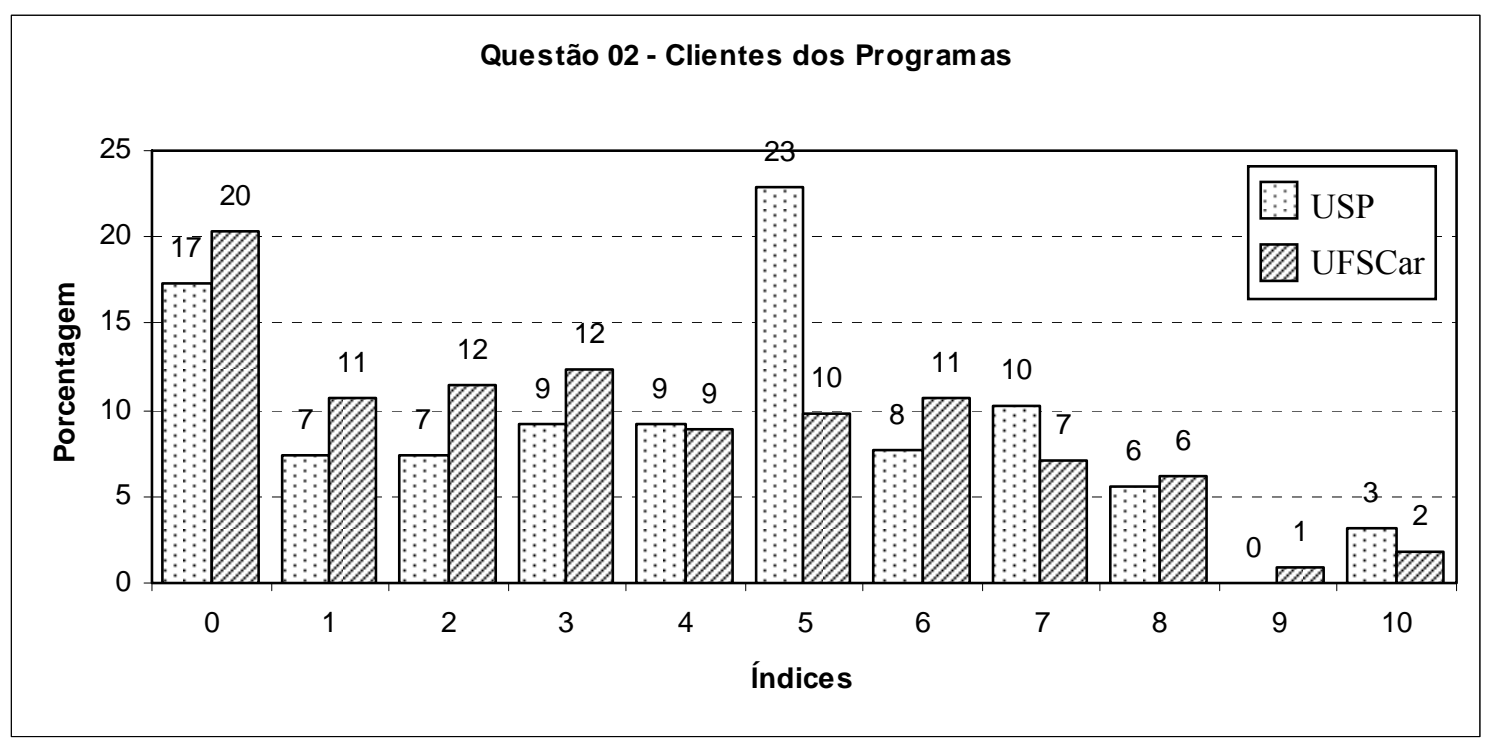

Figura 6.23: Respostas para questão 02 do questionário dos clientes.

De acordo com os clientes do programa da USP, para 3\% o programa sempre oferece cursos de aprendizado à comunidade, para 16\% o programa quase sempre os 
oferece, para $40 \%$ há cursos oferecidos moderadamente, $24 \%$ acreditam que quase nunca eles são oferecidos e para $17 \%$ nunca são oferecidos esses cursos.

De acordo com os dados para os clientes do Programa da UFSCar, para $16 \%$ deles o Programa sempre ou quase sempre oferece curso de aprendizado, $29 \%$ acreditam que os cursos são oferecidos de maneira moderada, 35\% acham que quase nunca os cursos são oferecidos e $20 \%$ crêem que nunca os cursos são oferecidos.

$\mathrm{Na}$ USP $41 \%$ e na UFSCar 55\% dos clientes acreditam que nunca ou quase nunca são oferecidos cursos de aprendizado a comunidade dos campi. Isso mostra uma deficiência nesse quesito, que na realidade trata da difusão ou distribuição do conhecimento ao público alvo dos programas. Além disso, os clientes que avaliaram como moderada a oferta de cursos é grande se for consideradas a importância da etapa de difusão do conhecimento.

A questão 03 do questionário teve a intenção de verificar se as pessoas estão interessadas no conhecimento oferecido ou se buscam o conhecimento. Para isso a seguinte afirmação foi formulada:

- Participo de palestras e eventos oferecidos pelo Programa

Os entrevistados concordaram ou não com essa afirmação, em grau que variava de zero para índice “nunca” e dez para índice "sempre”.

As respostas obtidas podem ser vistas na figura 6.24 . 


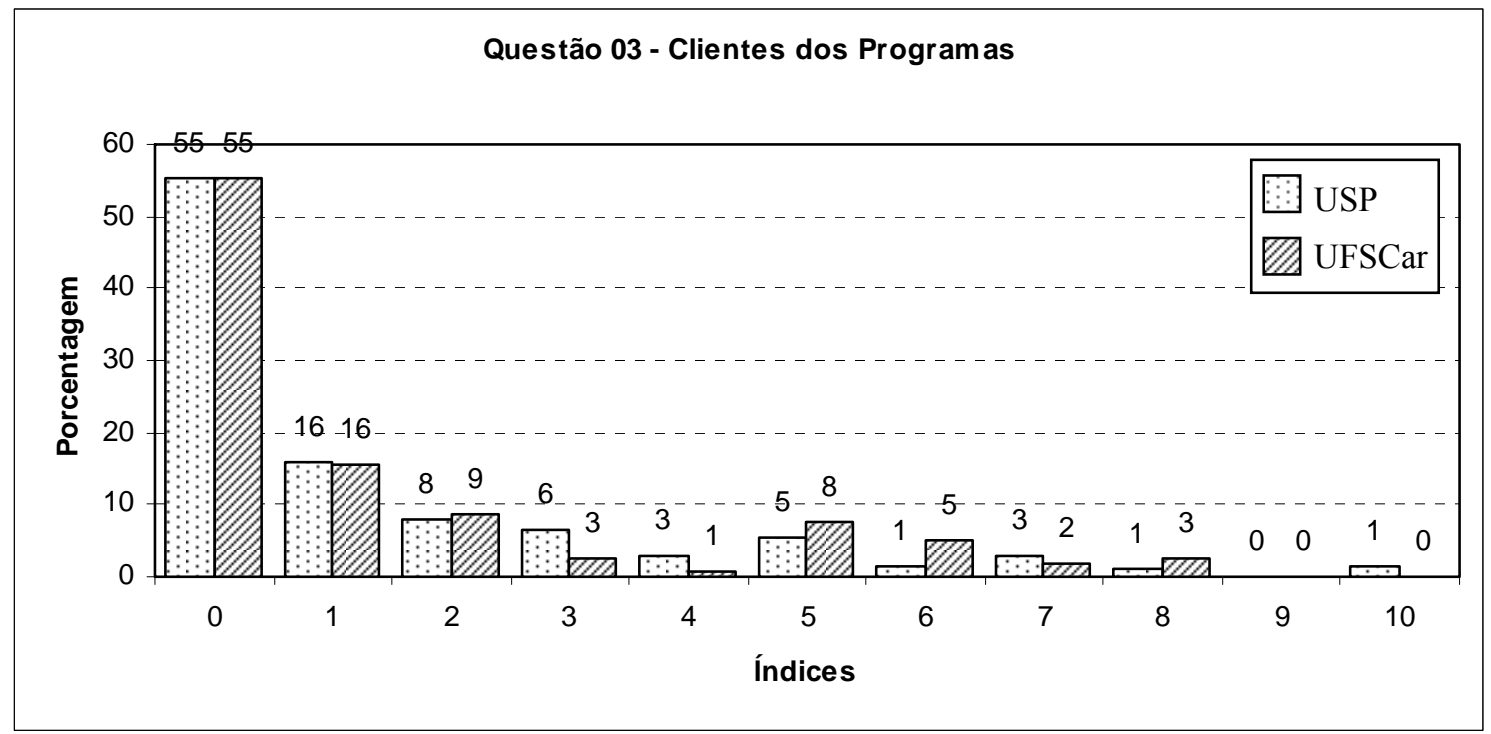

Figura 6.24: Respostas para questão 03 do questionário dos clientes.

De acordo com os clientes da USP, 55\% nunca participam de palestras e eventos do programa, 30\% quase nunca participam dos eventos e palestras, $9 \%$ participam de forma moderada e, somente, $5 \%$ quase sempre ou sempre participam.

Na UFSCar a opinião dos clientes é muito semelhante. 55\% nunca participam de palestras e eventos, $27 \%$ quase nunca participam dos mesmos, $14 \%$ acreditam que essa participação é moderada e 4\% nunca participam dos eventos e palestras oferecidos pelos Programas.

Isso mostra que em ambos os Programas 55\% dos clientes não participam das palestras e eventos oferecidos, o que significa que mais da metade do público-alvo não vai aos eventos informativos dos Programas, ou seja, não entra em contato com o conhecimento gerado. Sabendo-se disso, alguma medida de incentivo para chamar esse público aos eventos deveria ser tomada.

A questão 04 do questionário teve a intenção de verificar se os clientes têm acesso às informações do Programa e de que forma o acesso é feito. Para isso a seguinte afirmação foi formulada: 
- Tenho acesso às informações sobre o Programa

Os entrevistados concordaram ou não com essa afirmação respondendo "sim" ou "não" e posteriormente escolhendo o meio de acesso entre: internet, telefone, folhetos, cartazes ou palestras.

As respostas obtidas podem ser vistas nas figuras 6.25 e 6.26 .

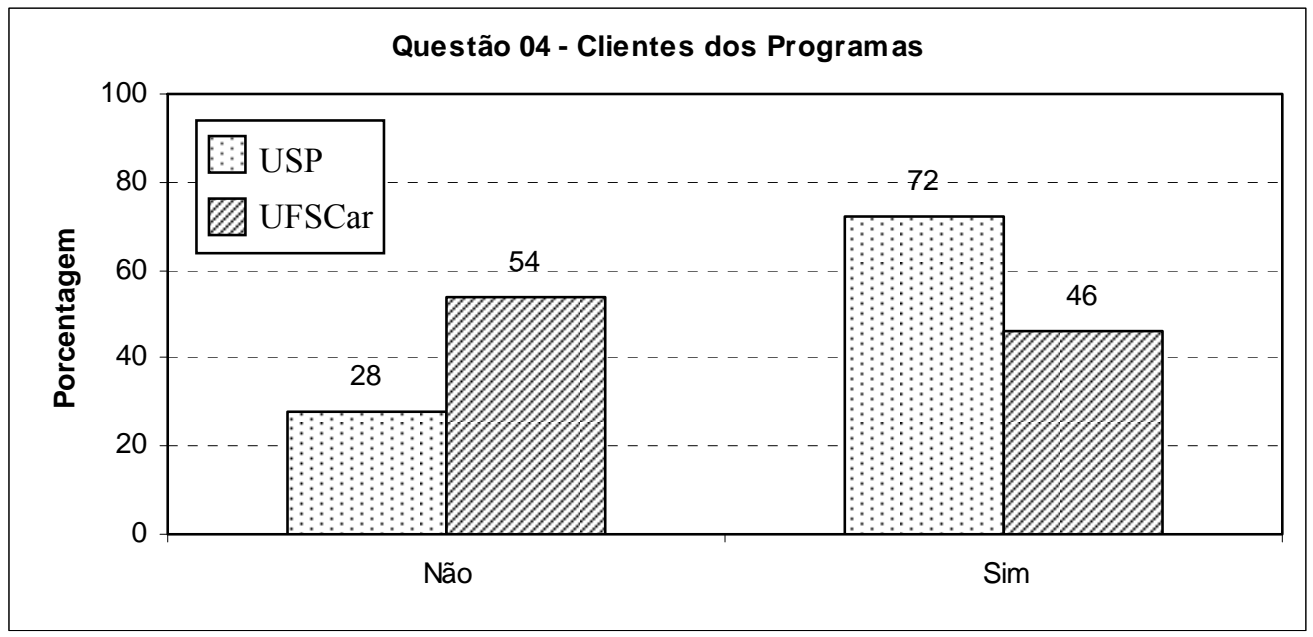

Figura 6.25: Respostas para questão 04 do questionário dos clientes.

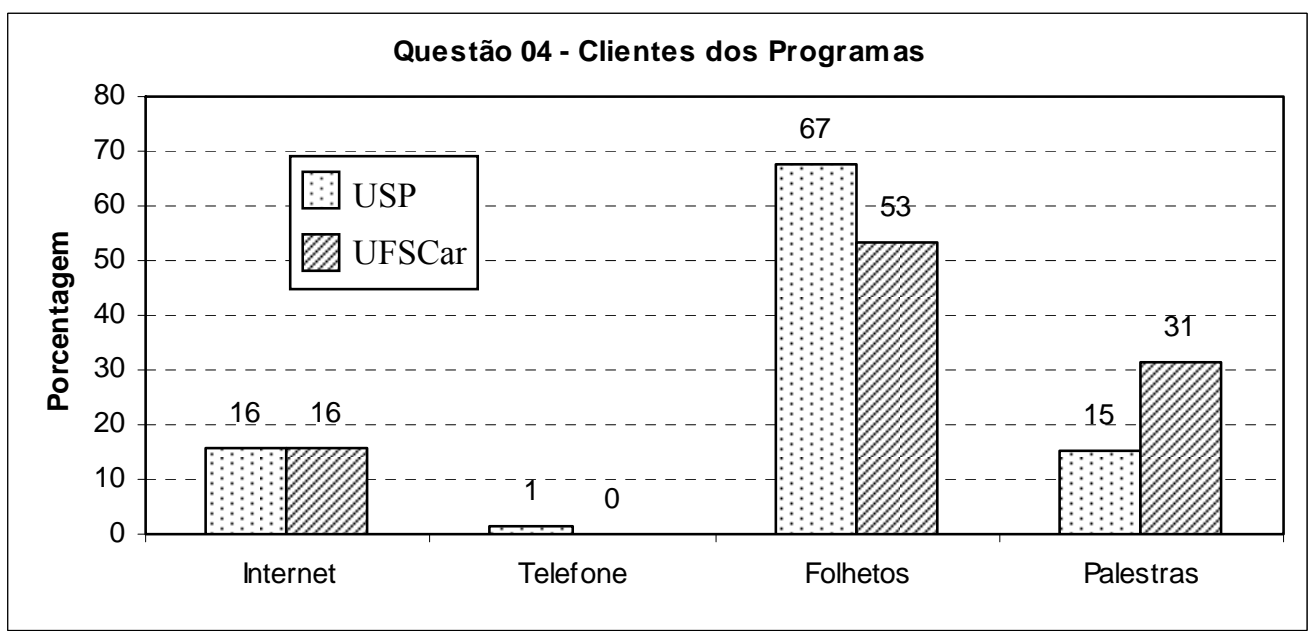

Figura 6.26: Respostas para questão 04 do questionário dos clientes.

De posso desses dados nota-se que na USP os clientes têm mais acesso as informações $(72 \%)$ e as obtêm preferencialmente por folhetos, seguido pela internet e palestras. 
$\mathrm{Na}$ UFSCar somente $46 \%$ dos clientes responderam que têm acesso as informações do Programa, um número baixo, já que se tem que considerar que poucas pessoas conhecem o Programa de acordo com a primeira questão. Isso poderia ser resolvido com campanhas direcionadas no RU da Universidade utilizando-se folhetos, que é o meio mais conhecido de informações dos clientes.

A questão 05 do questionário teve a intenção de verificar se o conhecimento está sendo aplicado.

Para isso a seguinte afirmação foi formulada:

- Contribuo com a coleta seletiva do Programa separando os materiais na Universidade

Os entrevistados concordaram ou não com essa afirmação, em grau que variava de zero para índice “nunca” e dez para índice "sempre”.

As respostas obtidas podem ser vistas na figura 6.27.

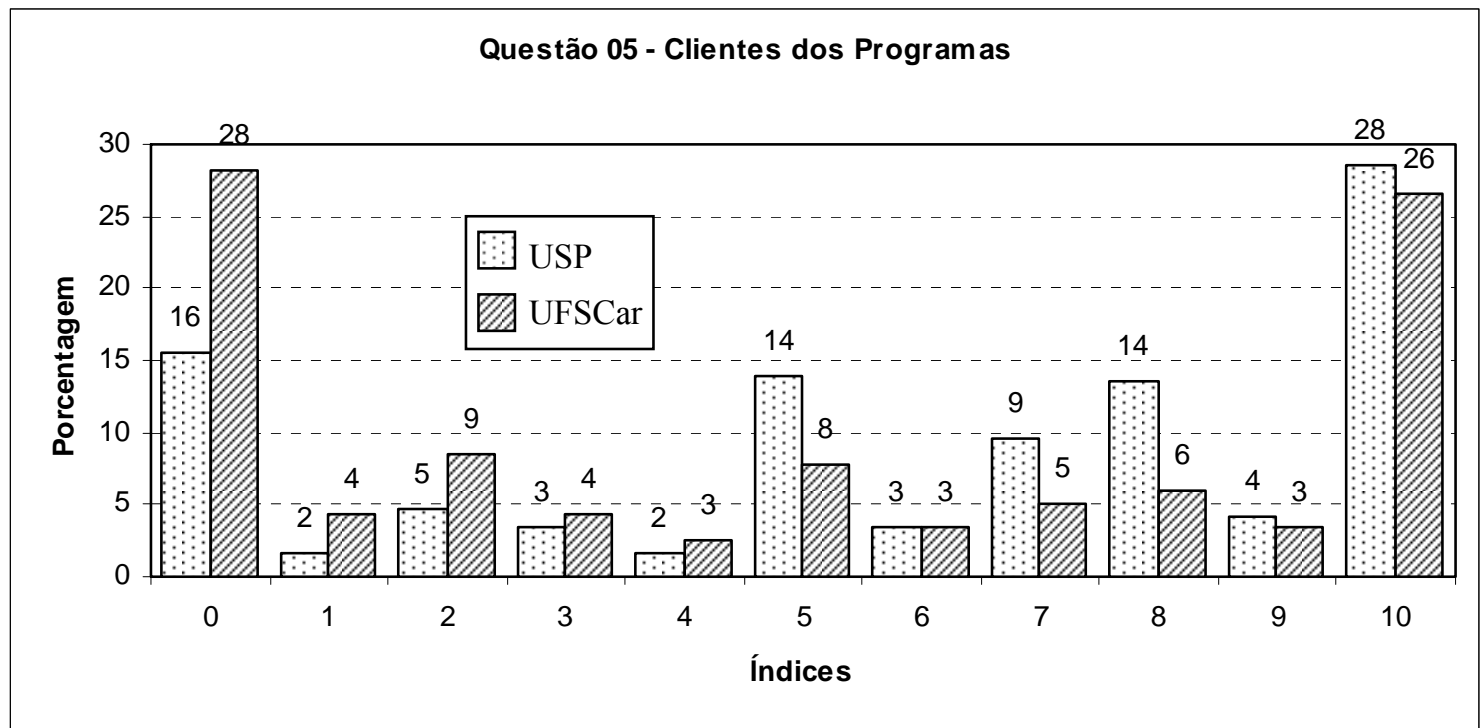

Figura 6.27: Respostas para questão 05 do questionário dos clientes. 
De acordo com os dados obtidos se observa que $28 \%$ dos clientes do Programa da USP sempre contribuem com a coleta seletiva, 27\% quase sempre, $19 \%$ contribuem moderadamente, $10 \%$ quase nunca contribuem e $16 \%$ nunca contribuem.

Na UFSCar, 26\% dos clientes do Programa sempre contribuem com a coleta seletiva, $15 \%$ quase sempre, $14 \%$ contribuem moderadamente, $17 \%$ quase nunca contribuem e $28 \%$ nunca contribuem.

De posse desses dados, se observa um baixo comprometimento dos clientes com a coleta seletiva dos materiais, provavelmente por falta de orientação ou de comprometimento com os ideais dos Programas.

A questão 06 do questionário teve a intenção de verificar se o conhecimento está sendo aplicado.

Para isso a seguinte afirmação foi formulada:

- Aplico o conhecimento aprendido com o Programa fora da Universidade

Os entrevistados concordaram ou não com essa afirmação, em grau que variava de zero para índice "nunca” e dez para índice "sempre”.

As respostas obtidas podem ser vistas na figura 6.28. 


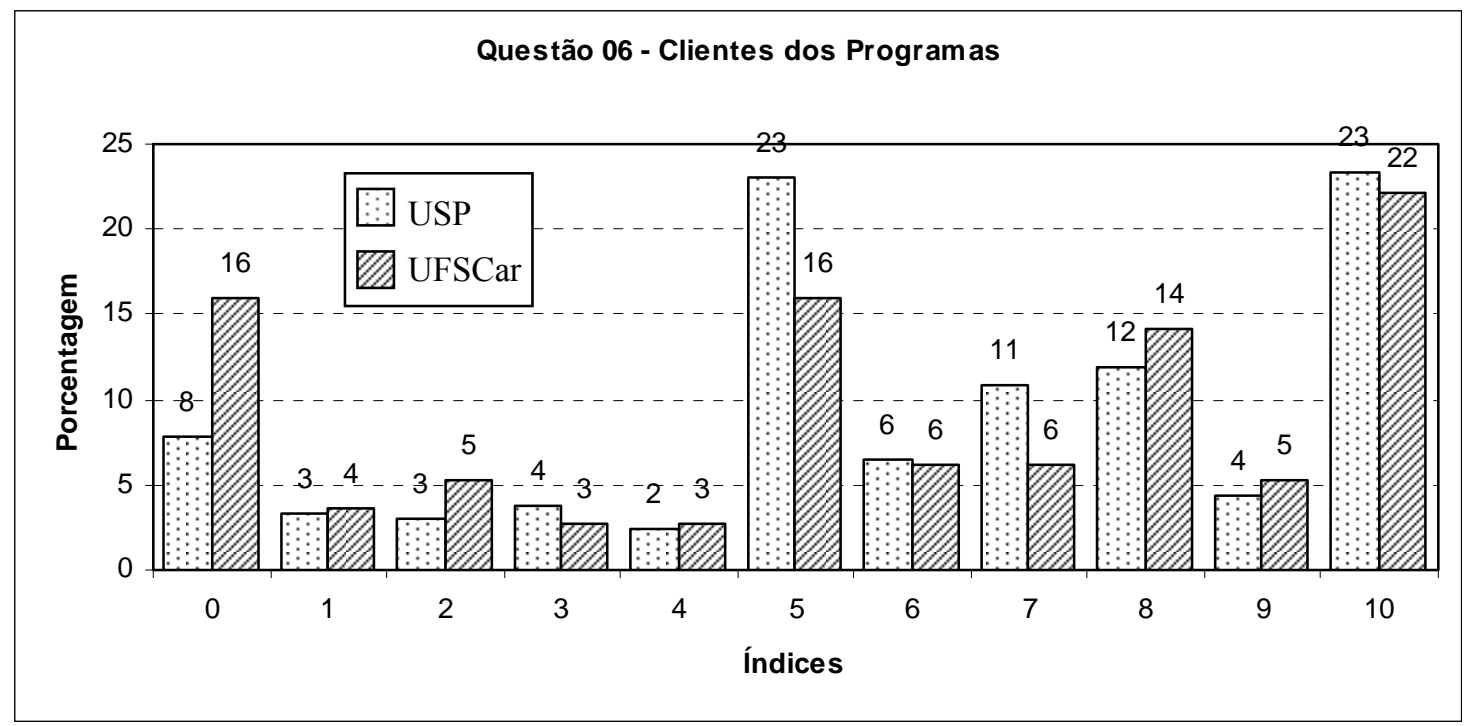

Figura 6.28: Respostas para questão 06 do questionário dos clientes.

Para os clientes da USP, 23\% sempre aplicam o conhecimento aprendido com o programa fora da Universidade, 27\% quase sempre aplicam, 32\% aplicam de forma moderada, $10 \%$ quase nunca e $8 \%$ nunca aplicam o conhecimento.

Os clientes da UFSCar têm comportamento parecido, 22\% sempre aplicam o conhecimento aprendido com o programa fora da Universidade, $26 \%$ quase sempre aplicam, 25\% aplicam de forma moderada, 12\% quase nunca e 16\% nunca aplicam o conhecimento fora da Universidade.

Isso mostra que o conhecimento aprendido com os Programas não fica restrito a eles, esse conhecimento é aplicado em ambientes externos aos dos Programas e mostra que o objetivo educacional dos Programas é cumprido, mas poderia ser melhor explorado, pois, embora aproximadamente $50 \%$ dos clientes apliquem o conhecimento fora da Universidade cerca de $20 \%$ nunca ou quase nunca o fazem.

A questão 07 do questionário teve a intenção de verificar se o conhecimento tácito é externalizado ou compartilhado.

Para isso a seguinte afirmação foi formulada: 
- Participo com sugestões/críticas para a melhoria do Programa

Os entrevistados concordaram ou não com essa afirmação, em grau que variava de zero para índice “nunca” e dez para índice "sempre”.

As respostas obtidas podem ser vistas na figura 6.29.

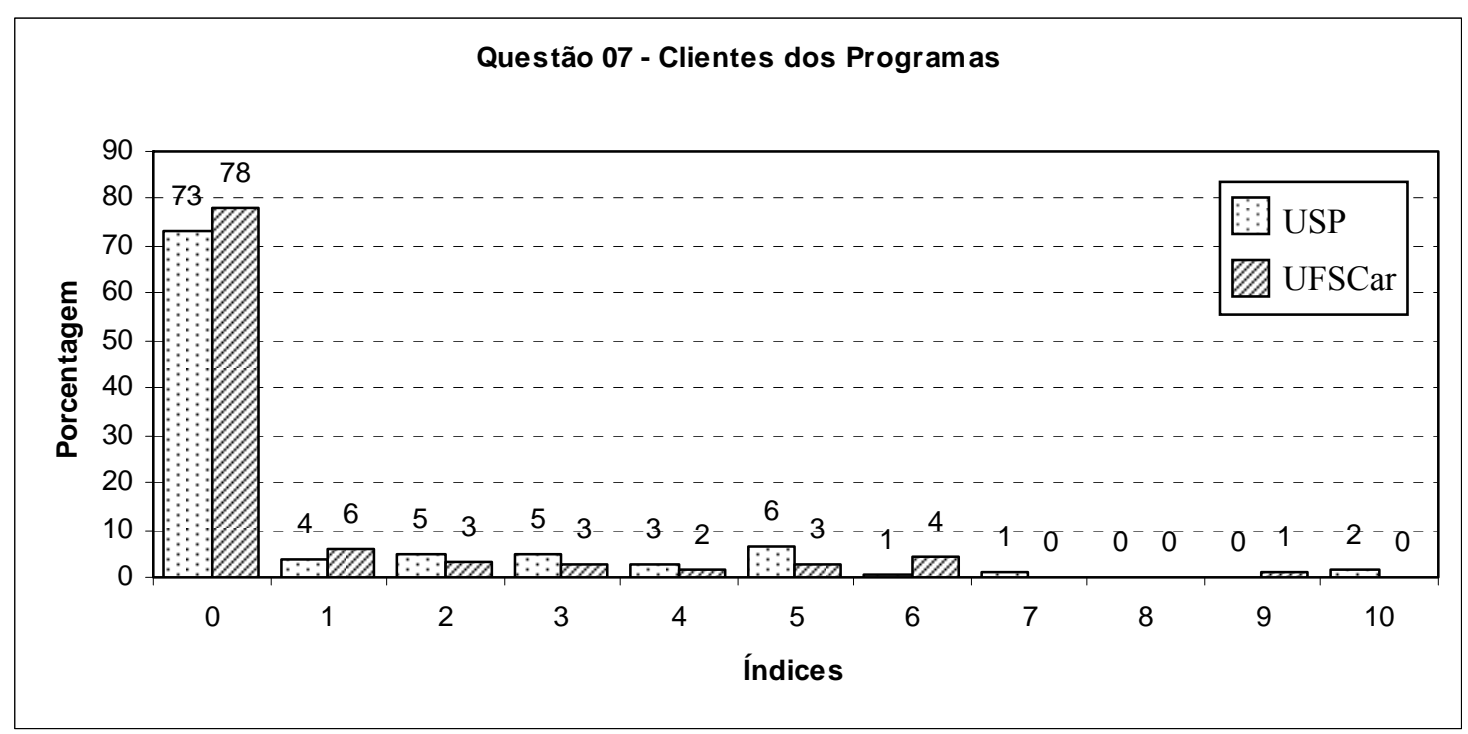

Figura 6.29: Respostas para questão 07 do questionário dos clientes.

Em relação à participação com sugestões e/ou críticas para a melhoria do Programa, os clientes da USP tem a seguinte característica: 73\% nunca participam com sugestões e/ou críticas, $14 \%$ quase nunca participam, 10\% participam moderadamente e $3 \%$ quase sempre ou sempre participam.

Os clientes da UFSCar têm característica muito semelhante, $78 \%$ nunca participam com sugestões e/ou críticas, $12 \%$ quase nunca participam, $9 \%$ participam de forma moderada e $1 \%$ quase sempre participam.

Esse comportamento relata que os clientes não participam com sugestões e/ou críticas ao Programa, mas seria interessante mudar esse comportamento para saber das necessidades dos usuários em relação aos métodos propostos pelos Programas. Além 
disso, a externalização do conhecimento é importante para que novos conhecimentos sejam criados na área.

A questão 08 do questionário teve a intenção de verificar se o conhecimento tácito é externalizado ou compartilhado.

Para isso a seguinte afirmação foi formulada:

- Minhas sugestões/críticas são ouvidas pelos superiores dentro Programa

Os entrevistados concordaram ou não com essa afirmação, em grau que variava de zero para índice "nunca” e dez para índice "sempre”.

As respostas obtidas podem ser vistas na figura 6.30 .

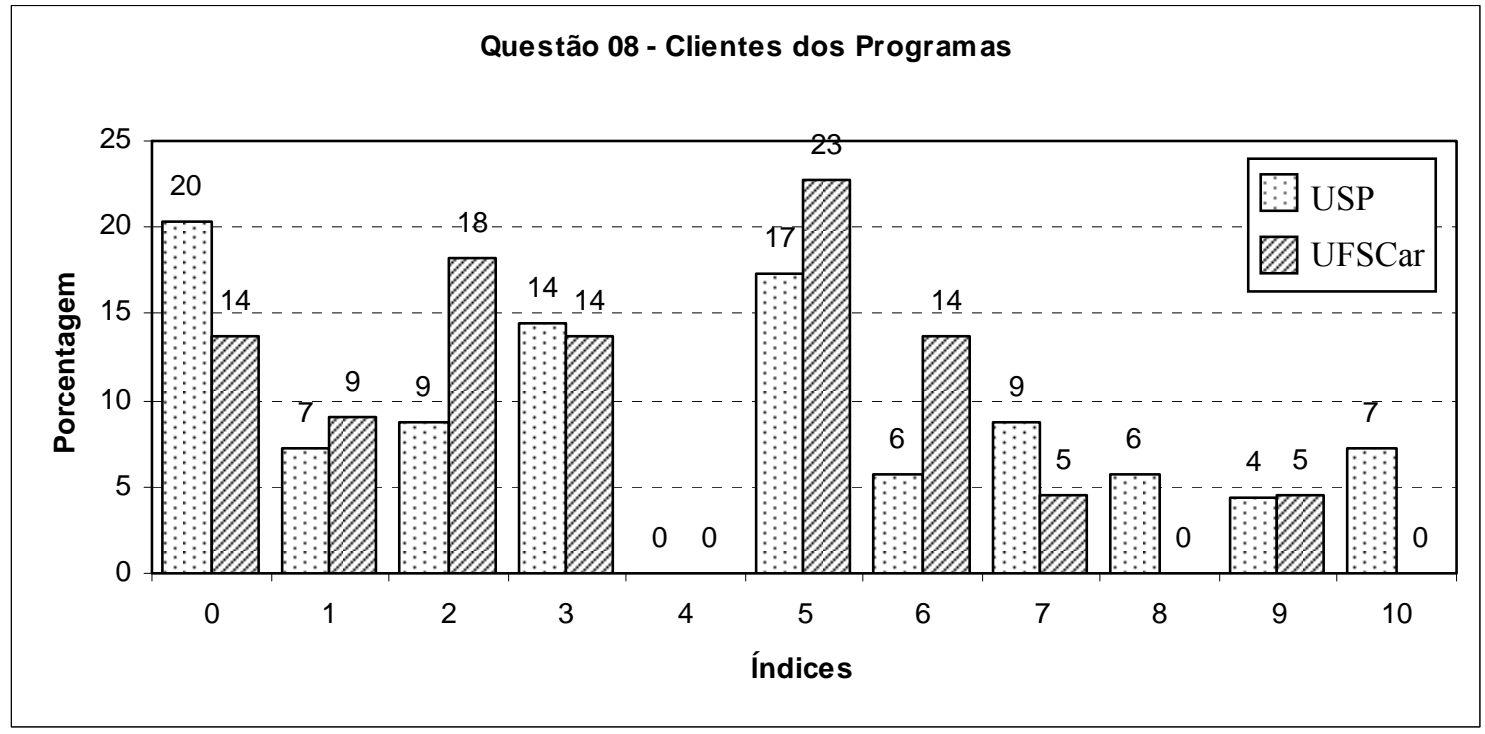

Figura 6.30: Respostas para questão 08 do questionário dos clientes.

É importante frisar que os entrevistados que responderam "não" para a pergunta anterior, questão 07, não responderam essa questão, pois não conseguiriam opinar se elas são ouvidas ou não. 
De acordo com os dados, na USP, 7\% dos clientes sempre têm suas sugestões e/ou críticas ouvidas pelos superiores dentro do Programa, outros 19\% quase sempre as tem ouvidas, $23 \%$ acham que são ouvidas de maneira moderada, $30 \%$ que quase nunca e $20 \%$ que nunca tem suas sugestões e/ou críticas ouvidas.

Na UFSCar, 9\% dos clientes quase sempre têm suas sugestões e/ou críticas ouvidas pelos superiores dentro do Programa, 36\% acham que suas críticas e/ou sugestões são ouvidas de maneira moderada, 41\% quase nunca tem suas críticas e/ou sugestões ouvidas, e 14\% que nunca tem suas sugestões e/ou críticas ouvidas.

Como dito anteriormente, ter as críticas e/ou sugestões ouvidas pelo Programa é de grande importância para a combinação do conhecimento, pois o mesmo pode ser externalizado e não aproveitado. A partir do momento em que as sugestões e/ou críticas são ouvidas se criam novos conhecimentos dando seguimento a espiral já apresentada.

Ainda, ouvindo a opinião dos clientes, etapas podem ser cortadas, rumos e abordagens diferentes podem ser tomados e os Programas podem ser melhor adequados aos seus usuários e com isso ter um ganho em adesão ao mesmo. Por isso um esforço para agrupar e analisar todas as sugestões ou críticas ao programa deve ser feito.

A questão 09 do questionário teve a intenção de verificar como são fornecidas as informações aos clientes.

Para isso a seguinte afirmação foi formulada:

- As informações fornecidas pelo Programa são

Os entrevistados concordaram ou não com essa afirmação, em grau que variava de zero para índice “confusas” e dez para índice “claras”. 
As respostas obtidas podem ser vistas na figura 6.31.

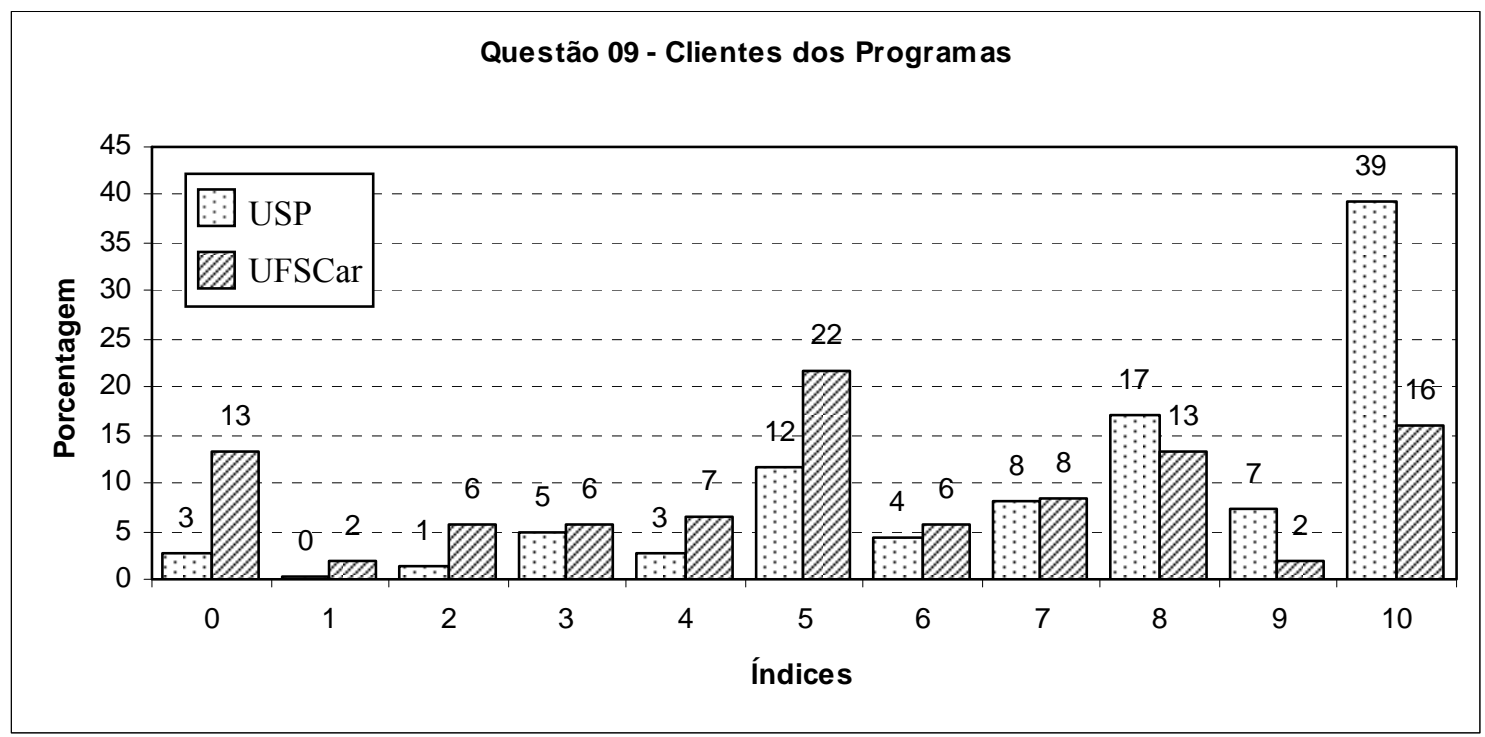

Figura 6.31: Respostas para questão 09 do questionário dos clientes.

Na USP a avaliação dos clientes foi a seguinte: 39\% acham que as informações são muito claras, 33\% que são claras, $19 \%$ razoavelmente claras, $7 \%$ pouco confusas e $3 \%$ que são confusas.

Na UFSCar para $16 \%$ dos clientes as informações são muito claras, para $24 \%$ são claras, para $34 \%$ são razoavelmente claras, para $13 \%$ pouco confusas e outros $13 \%$ acham que são confusas.

De modo geral, em ambos os Programas, a clareza das informações está em um nível aceitável para os clientes, não demandando urgência na melhora, mas na UFSCar as informações poderiam ser mais difundidas para que os $26 \%$ de clientes que avaliaram como pouco confusas ou confusas possam melhor avalia-lo.

A questão 10 do questionário teve a intenção de verificar a adesão com a iniciativa dos programas.

Para isso a seguinte afirmação foi formulada: 
- Em relação às iniciativas tomadas pelo Programa

Os entrevistados concordaram ou não com essa afirmação, em grau que variava de zero para índice “discordo” e dez para índice “concordo”.

As respostas obtidas podem ser vistas na figura 6.32 .

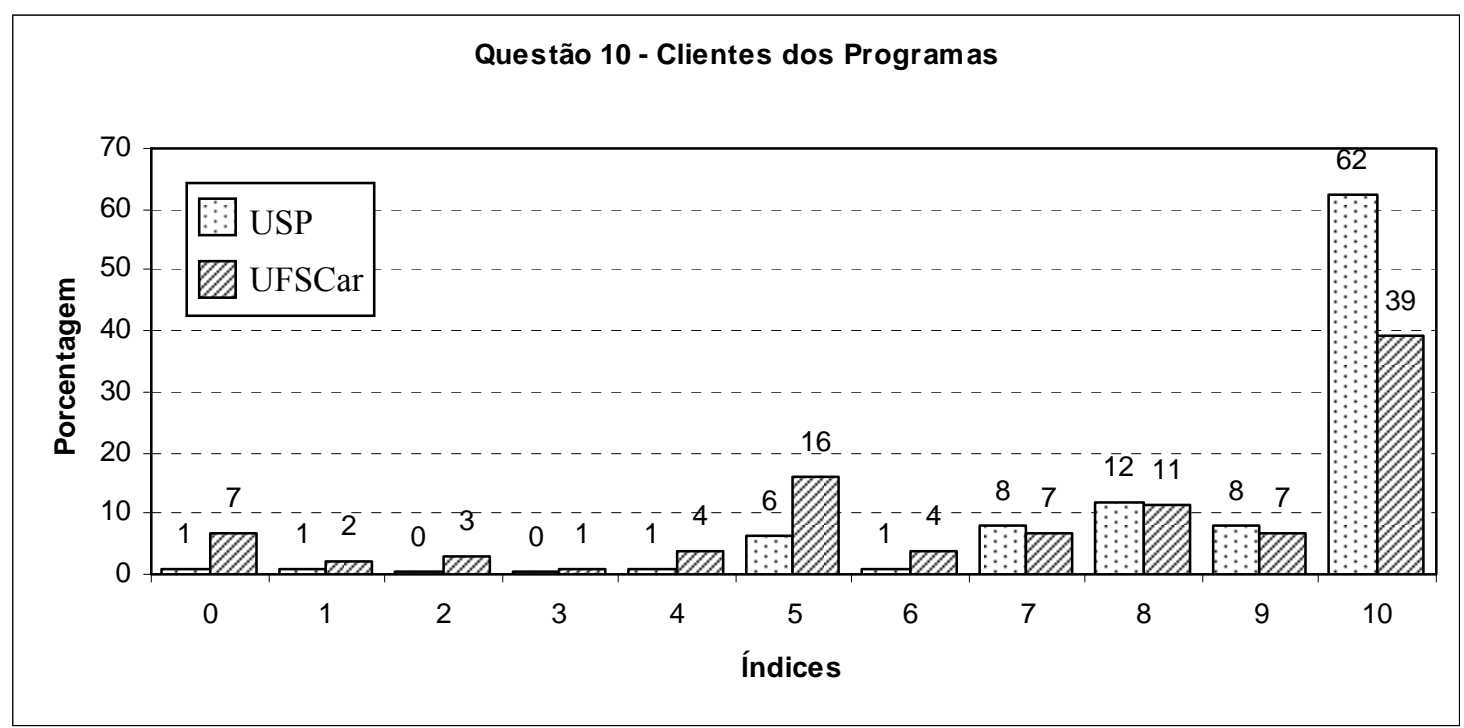

Figura 6.32: Respostas para questão 10 do questionário dos clientes.

Na USP $62 \%$ dos clientes sempre concordam com as iniciativas tomadas pelo Programa, $27 \%$ quase sempre concordam, $8 \%$ concordam de forma moderada e $2 \%$ quase nunca concordam ou discordam.

Já na UFSCar, 39\% dos clientes sempre concordam com as iniciativas tomadas pelo Programa, $25 \%$ quase sempre concordam, $24 \%$ concordam de forma moderada, $6 \%$ quase nunca concordam e 7\% discordam.

Isto revela uma ótima aceitação das iniciativas do Programa na USP, já na UFSCar essa aceitação é menor e seria necessário uma pesquisa para verificar onde está o problema da baixa aceitação. 
A questão 11 do questionário teve a intenção de verificar se os Programas influenciam de alguma forma a relação dos gestores com as questões ambientais.

Para isso a seguinte afirmação foi formulada:

- O Programa influencia de alguma forma minha relação com as questões ambientais

Os entrevistados concordaram ou não com essa afirmação, em grau que variava de zero para índice “nunca” e dez para índice "sempre”.

As respostas obtidas podem ser vistas na figura 6.33 .

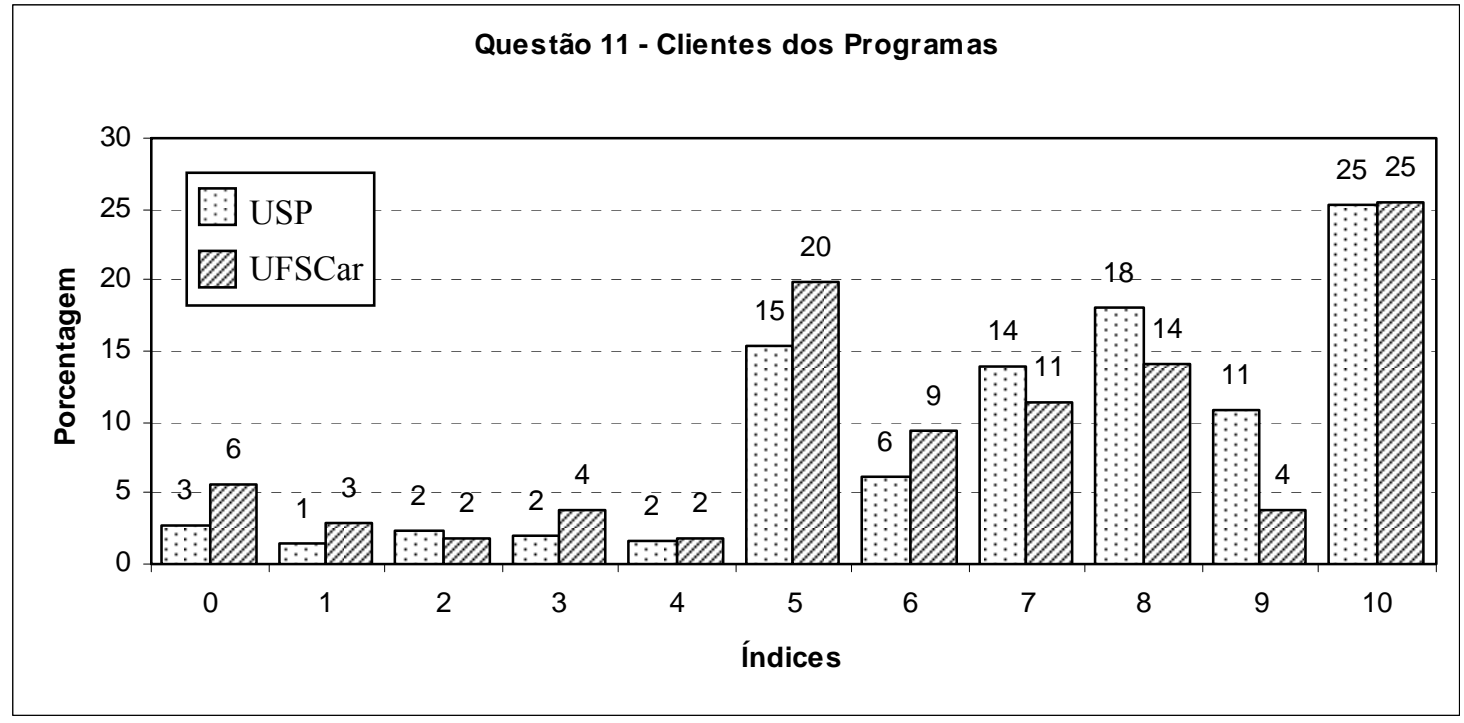

Figura 6.33: Respostas para questão 11 do questionário dos clientes.

De acordo com a pesquisa, para $25 \%$ dos clientes da USP o Programa sempre influencia de alguma forma as relações com as questões ambientais, para $43 \%$ essa influência ocorre quase sempre, $23 \%$ acham que a influência é moderada e $9 \%$ que nunca ou quase nunca são influenciados.

Na UFSCar, para 25\% dos clientes o Programa sempre influencia de alguma forma as relações com as questões ambientais, para $29 \%$ essa influência ocorre quase 
sempre, $31 \%$ crêem que a influencia é moderada e $15 \%$ que nunca ou quase nunca são influenciados.

Assim, conclui-se que o programa influencia seus clientes com as questões ambientais.

Com a finalidade de avaliar o questionário a seguinte questão foi colocada ao final do mesmo:

- Avalie somente o questionário

As respostas obtidas podem ser vistas na figura 6.34 .

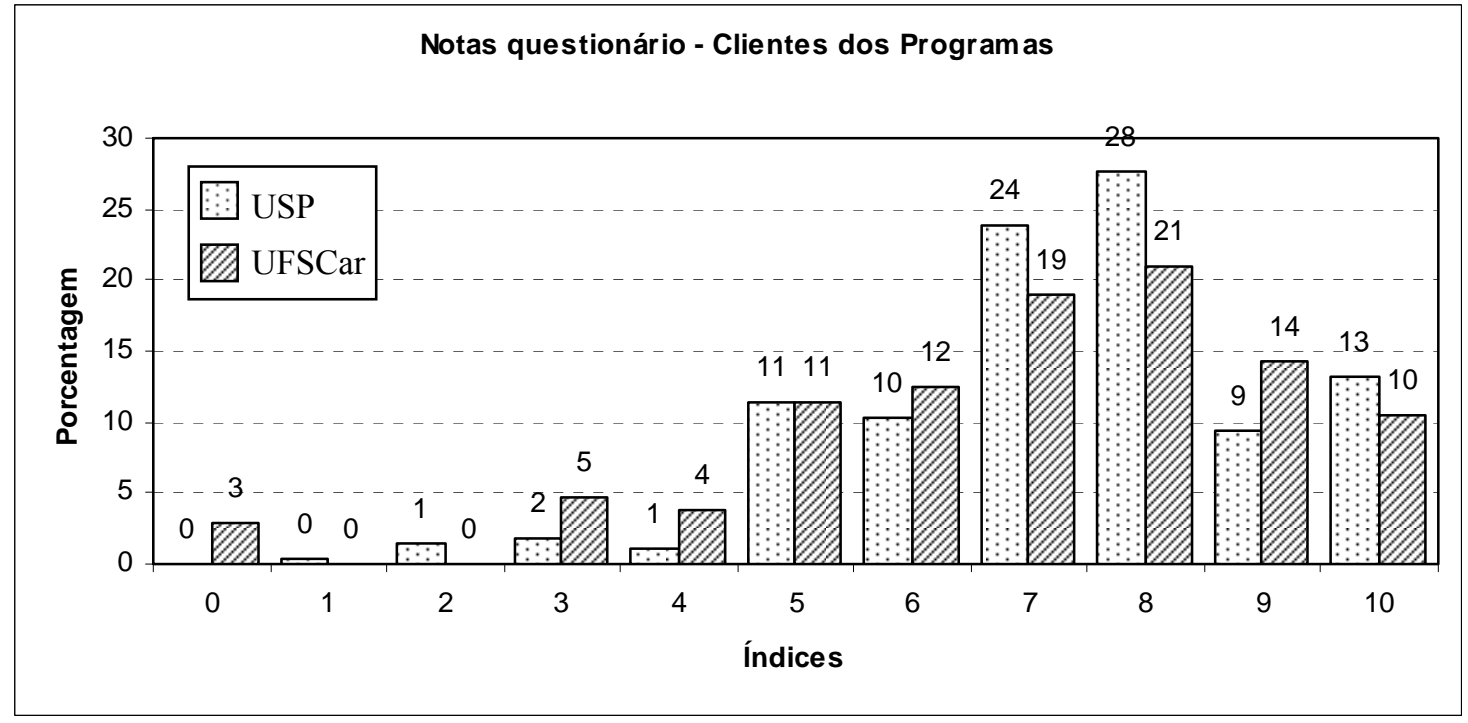

Figura 6.34: Respostas para as Notas do questionário dos clientes.

Em ambas as Universidades a médias das notas foi de, aproximadamente sete (7), mostrando que o questionário foi aceito pelos clientes. 


\section{3 - RESULTADOS OBTIDOS PARA O GRUPO DE FUNCIONÁRIOS}

Nesse sub-item serão apresentados somente os resultados obtidos para o grupo de funcionários do programa da USP. Para isso, foram entrevistados 50 funcionários do programa.

O questionário primeiramente caracterizou os funcionários de acordo com o sexo e cargo que ocupam na instituição. Esses dados são apresentados nas figuras 6.35 e 6.36.

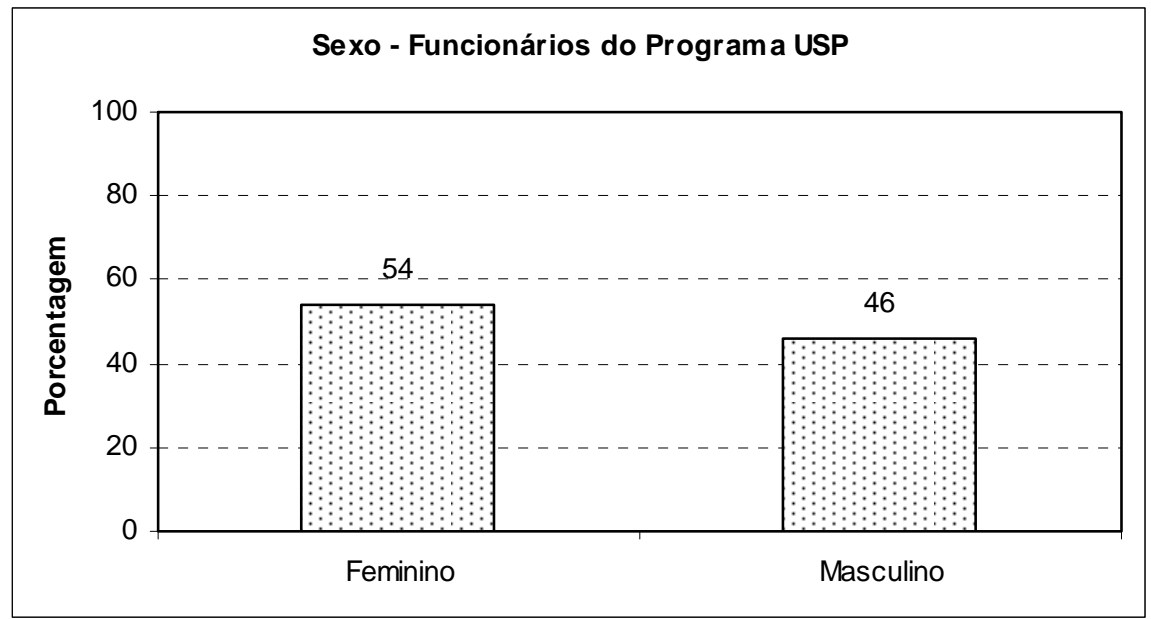

Figura 6.35: Caracterização dos funcionários do Programa da USP.

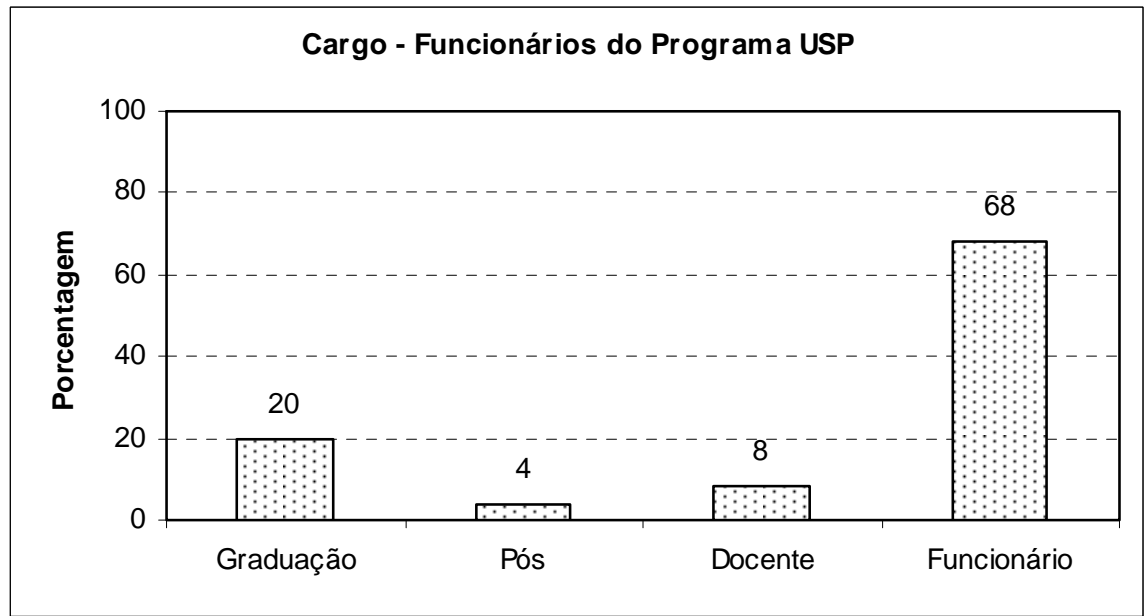

Figura 6.36: Caracterização dos funcionários do Programa da USP. 
Como se pode notar os funcionários do Programa da USP são, em sua maioria (54\%), do sexo feminino. Em relação ao cargo na Universidade, 68\% são funcionários da USP, $8 \%$ são docentes, $4 \%$ estudantes de pós-graduação e $20 \%$ são estudantes de graduação.

Um dado interessante é notar a presença de estudantes de graduação no quadro de funcionários do Programa, o que pode ser muito útil ao mesmo, já que esses estudantes podem levar as necessidades da classe ao Programa.

Agora a análise das questões do questionário será feita individualmente, questão por questão como feito anteriormente nas outras classes de entrevistados.

A questão 01 do questionário teve a intenção de verificar se o entrevistado conhecia o Programa. Para isso a seguinte afirmação foi formulada:

\section{- Conheço o Programa}

Os entrevistados concordaram ou não com essa afirmação respondendo sim ou não.

As respostas obtidas podem ser vistas na figura 6.37 .

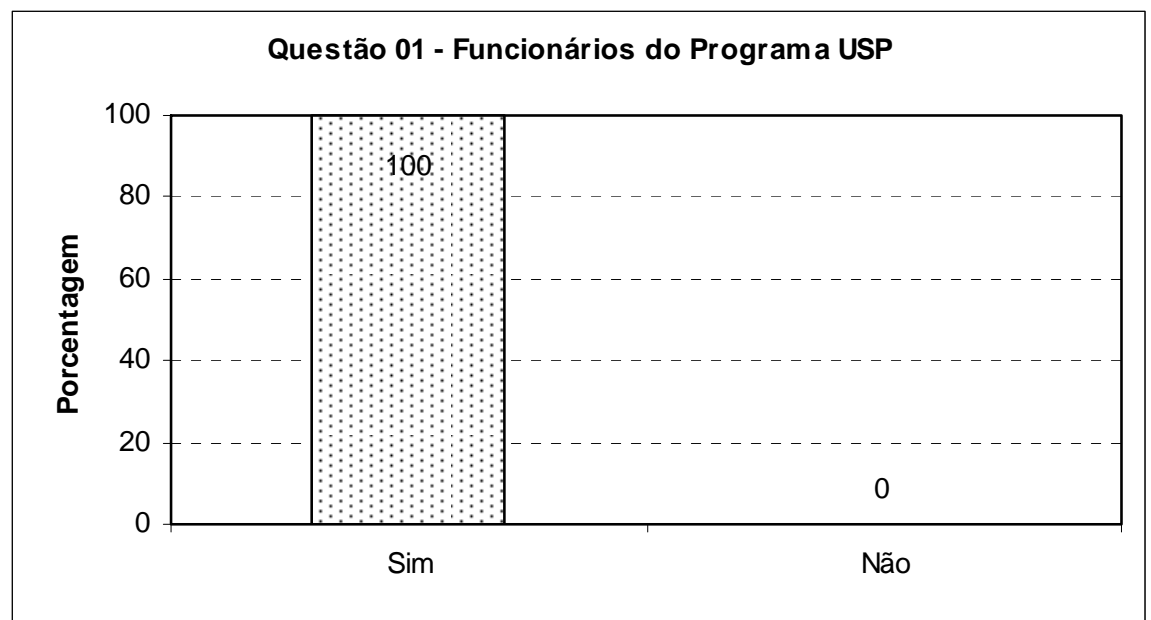

Figura 6.37: Respostas para questão 01 do questionário dos funcionários do Programa da USP 
É importante frisar que os entrevistados que responderam "não" para essa primeira questão não responderiam o restante do questionário, pois uma pessoa que não conhecesse o Programa não teria condições de fornecer dados sobre o mesmo.

Observou-se que $100 \%$ dos funcionários do programa conheciam o mesmo. Resultado já esperado, pois têm sua rotina ligada ao Programa.

A questão 02 do questionário teve a intenção de verificar se o conhecimento está sendo difundido. Para isso a seguinte afirmação foi formulada:

- Recebo cursos de aprendizado por parte do Programa

Os entrevistados concordaram ou não com essa afirmação, em grau que variava de zero para índice "nunca” e dez para índice "sempre”.

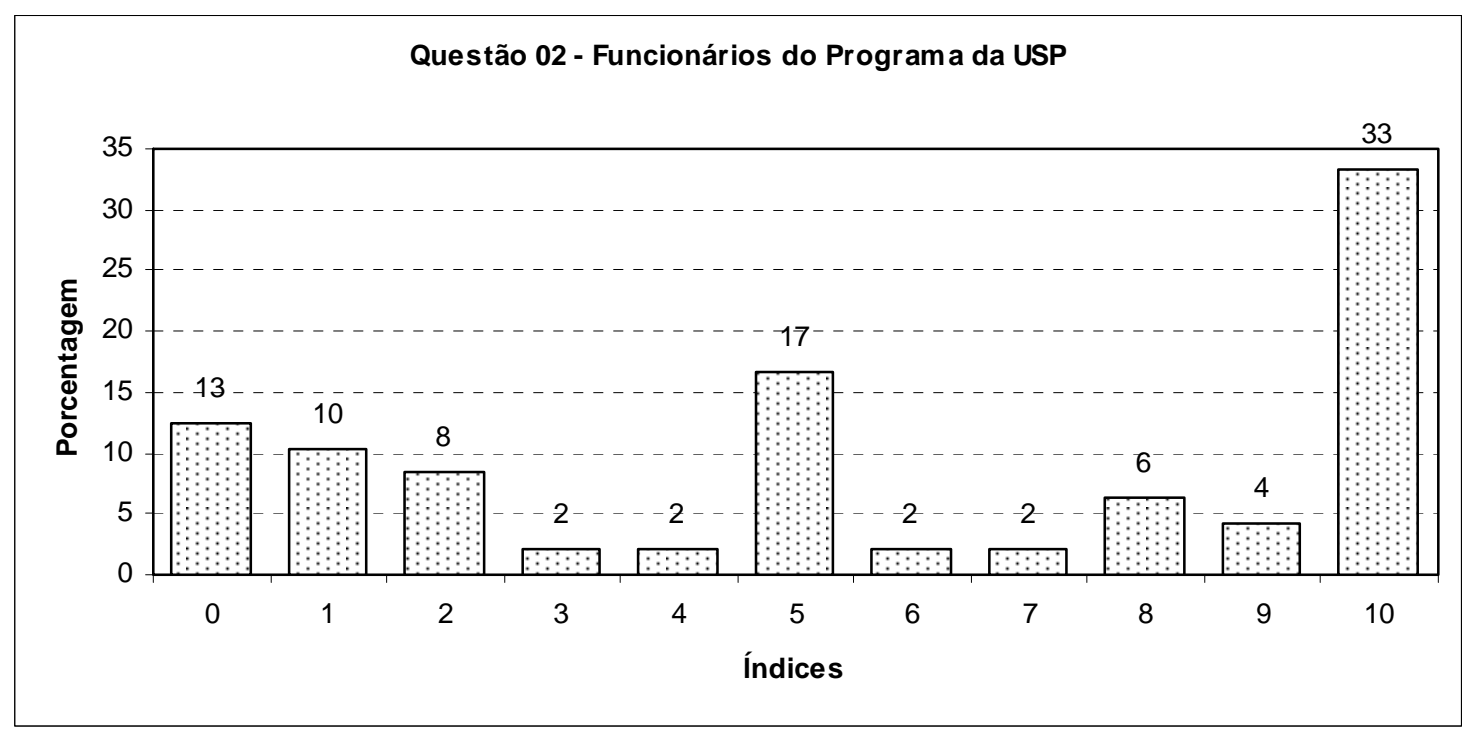

Figura 6.38: Respostas para questão 02 do questionário dos funcionários do Programa da USP

De acordo com os funcionários do Programa, 33\% sempre recebem cursos de aprendizado, $13 \%$ quase sempre recebem cursos, $21 \%$ recebem cursos moderadamente, $21 \%$ quase nunca e $13 \%$ acreditam que nunca recebem cursos de aprendizado. 
Assim, notou-se que grande parte dos funcionários sente carência no oferecimento de cursos de aprendizado oferecidos pelo Programa da USP. Isso pode mostrar que, embora o conhecimento seja criado, ele não é disseminado pelos gestores e a única solução encontrada para esse problema seria o Programa da USP oferecer mais cursos de aprendizado aos seus funcionários.

A questão 03 do questionário teve a intenção de verificar se os funcionários têm acesso às informações do Programa e de que forma o acesso é feito. Para isso a seguinte afirmação foi formulada:

- Tenho acesso às informações sobre o Programa

Os entrevistados concordaram ou não com essa afirmação respondendo sim ou não e em seguida escolheram o meio de acesso entre: internet, telefone, folhetos, cartazes ou palestras.

As respostas obtidas podem ser vistas nas figuras 6.39 e 6.40 .

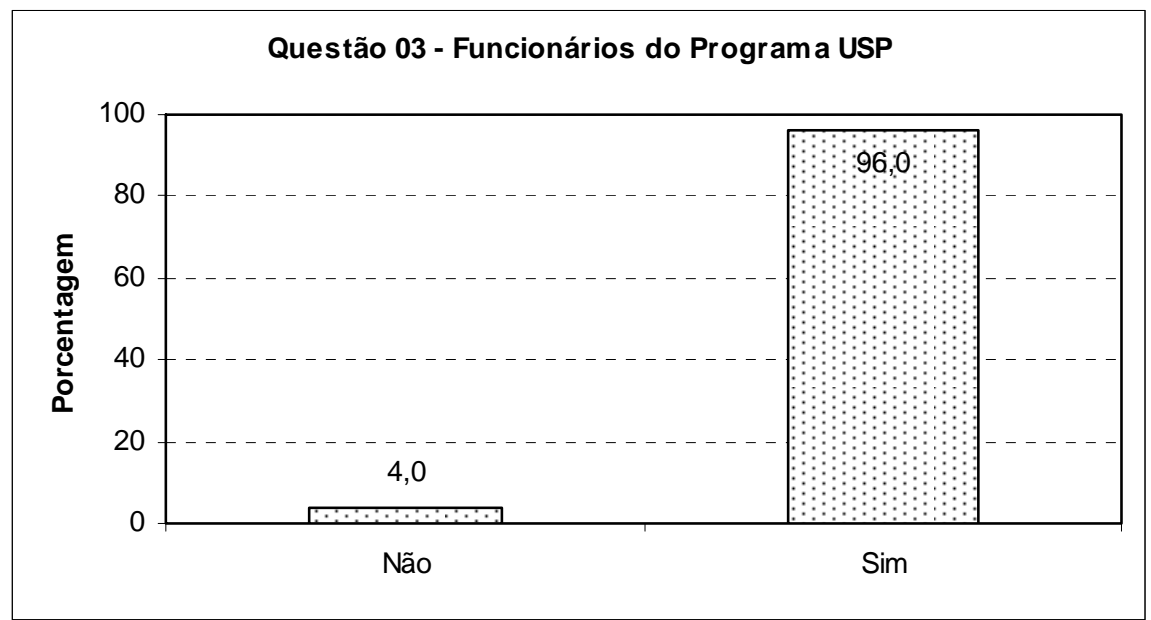

Figura 6.39: Respostas para questão 03 do questionário dos funcionários do Programa da USP 


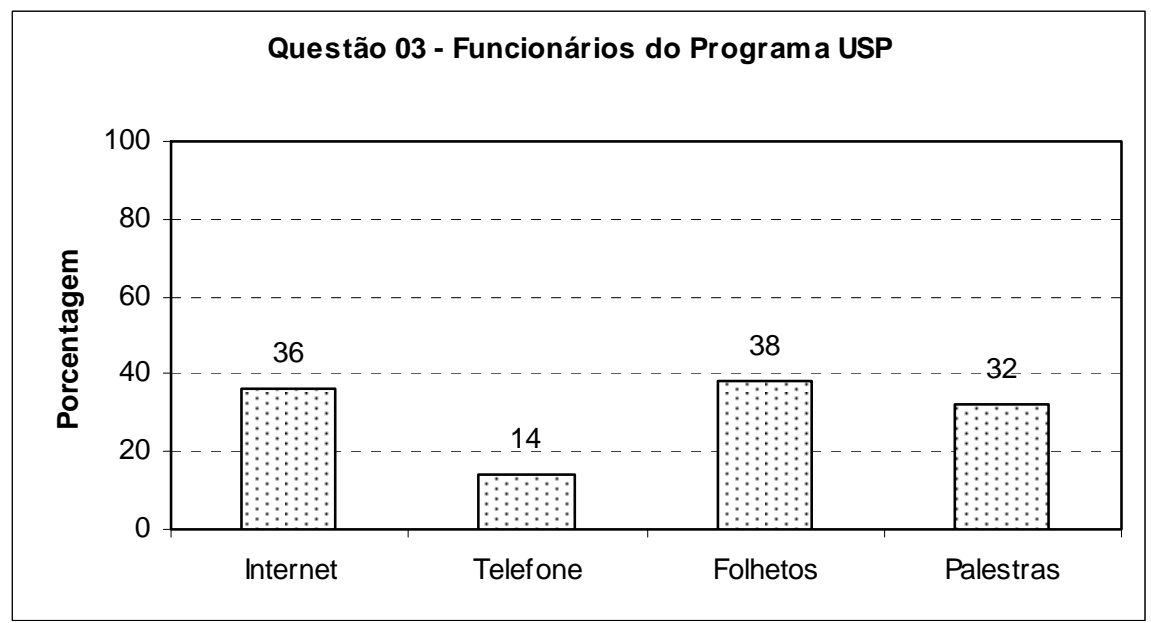

Figura 6.40: Respostas para questão 03 do questionário dos funcionários do Programa da USP

Cerca de $96 \%$ dos funcionários responderam que tem acesso as informações, o que mostra que o acesso está muito bom. Esse acesso às informações é feito principalmente por folhetos, seguido pelo uso da internet, pelas palestras oferecidas e, finalmente, por telefone.

Ainda que os funcionários afirmem que as palestras escassas, cerca de $30 \%$ as tem como fonte de informações. Isso mostra que as palestras são de grande importância para os funcionários como fonte de informação.

A questão 04 do questionário teve a intenção de verificar se o conhecimento está sendo aplicado.

Para isso a seguinte afirmação foi formulada:

- Contribuo com a coleta seletiva do Programa separando os materiais na Universidade

Os entrevistados concordaram ou não com essa afirmação, em grau que variava de zero para índice “nunca” e dez para índice "sempre”.

As respostas obtidas podem ser vistas na figura 6.41 . 


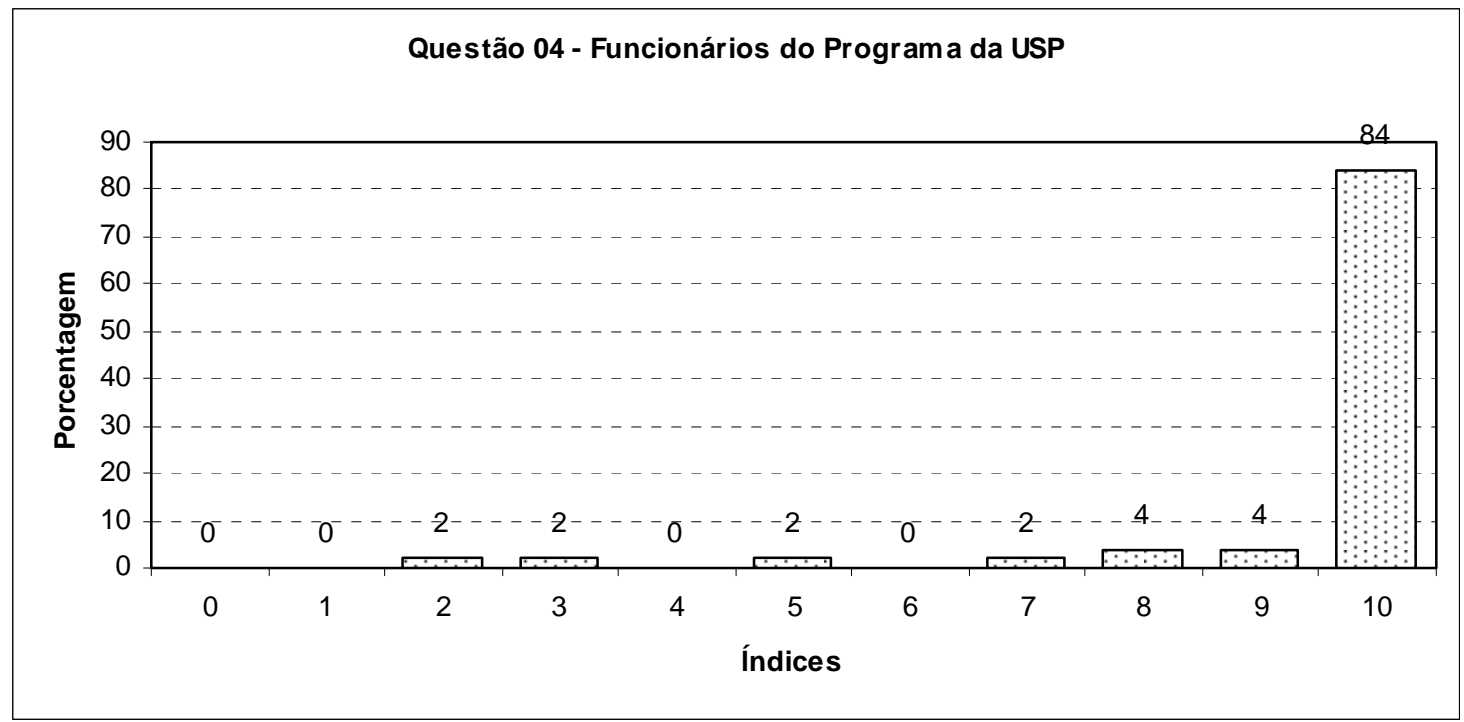

Figura 6.41: Respostas para questão 04 do questionário dos funcionários do Programa da USP

De acordo com os dados obtidos se observa que $84 \%$ dos funcionários do Programa da USP sempre contribuem com a coleta seletiva, 10\% quase sempre, $2 \%$ contribuem moderadamente e $4 \%$ quase nunca contribuem.

De posse desses dados, se observa um alto comprometimento dos funcionários com a coleta seletiva dos materiais, o que mostra que o conhecimento aprendido é aplicado.

A questão 05 do questionário teve a intenção de verificar se o conhecimento é aplicado.

Para isso a seguinte afirmação foi formulada:

- Aplico o conhecimento aprendido com o Programa fora da Universidade

Os entrevistados concordaram ou não com essa afirmação, em grau que variava de zero para índice “nunca” e dez para índice "sempre”.

As respostas obtidas podem ser vistas na figura 6.42 . 


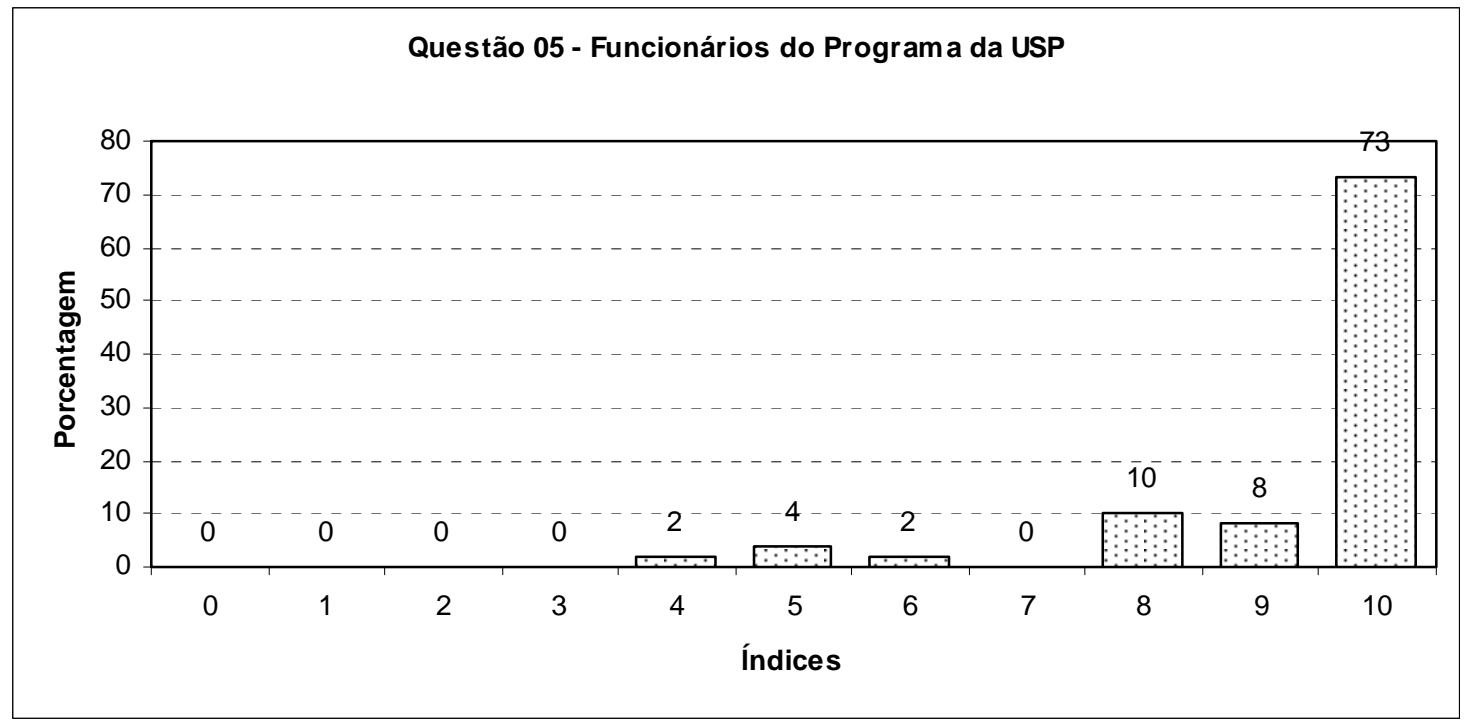

Figura 6.42: Respostas para questão 05 do questionário dos funcionários do Programa da USP

Para os funcionários do Programa da USP, 73\% sempre aplicam o conhecimento aprendido com o programa fora da Universidade, 18\% quase sempre aplicam e $8 \%$ aplicam de forma moderada.

Isso mostra que o conhecimento aprendido com os Programas não fica restrito a eles, esse conhecimento é aplicado em ambientes externos aos dos Programas e mostra que o objetivo educacional dos Programas é cumprido.

A questão 06 do questionário teve a intenção de verificar se o conhecimento tácito é externalizado ou compartilhado.

Para isso a seguinte afirmação foi formulada:

- Participo com sugestões/críticas para a melhoria do Programa

Os entrevistados concordaram ou não com essa afirmação, em grau que variava de zero para índice "nunca” e dez para índice "sempre”.

As respostas obtidas podem ser vistas na figura 6.43 . 


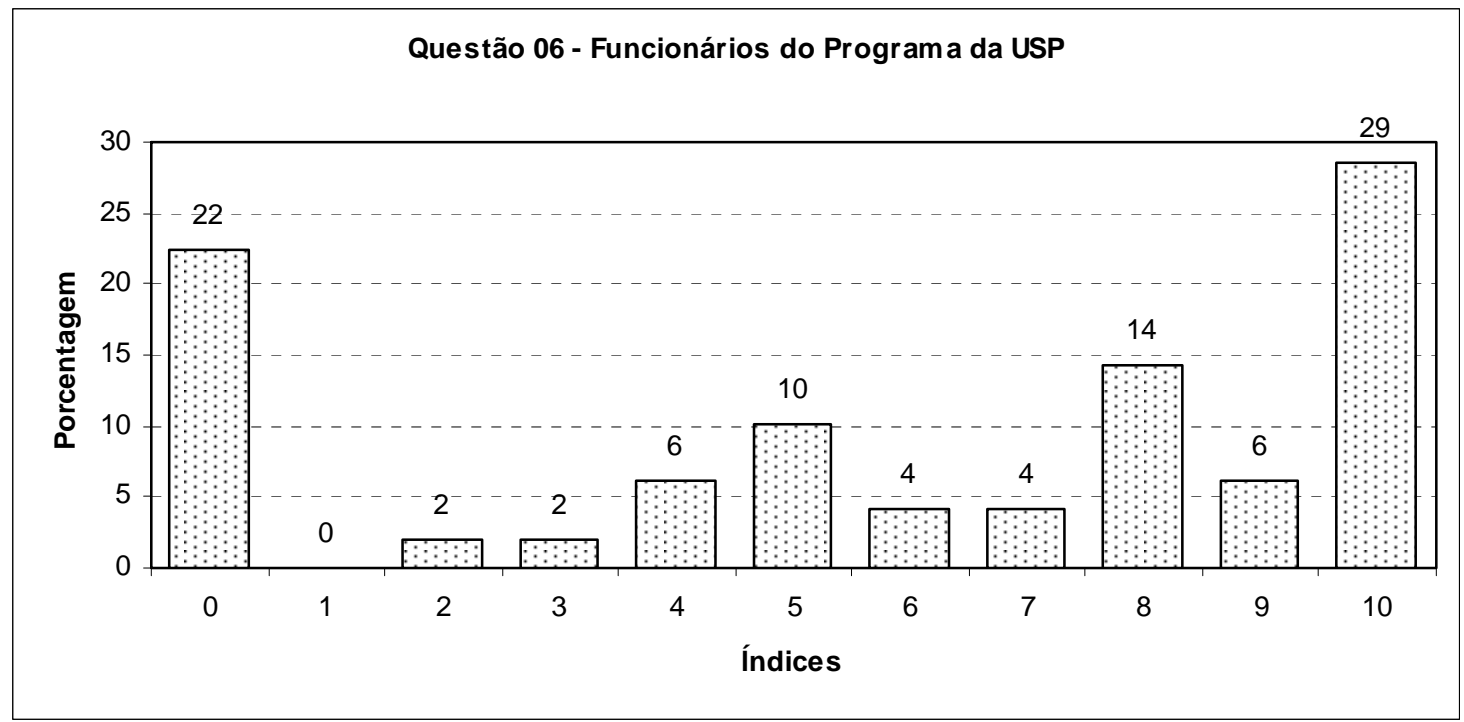

Figura 6.43: Respostas para questão 06 do questionário dos funcionários do Programa da USP

Em relação à participação com sugestões e/ou críticas para a melhoria do Programa, os funcionários do Programa da USP têm as seguintes características: 29\% sempre participam com sugestões e/ou críticas, 24\% quase sempre, $20 \%$ participam moderadamente, $4 \%$ quase nunca participam e $22 \%$ nunca participam.

Esse comportamento relata que os funcionários participam com sugestões e/ou críticas ao Programa, mas seria interessante sensibilizar as pessoas que nunca ou quase nunca tem essa participação, que são aproximadamente $25 \%$, visando conhecer as necessidades dos funcionários em relação aos métodos propostos pelos Programas. Além disso, a externalização do conhecimento é importante para que novos conhecimentos sejam criados na área.

A questão 07 do questionário teve a intenção de verificar se o conhecimento tácito é externalizado ou compartilhado.

Para isso a seguinte afirmação foi formulada:

- Minhas sugestões/críticas são ouvidas pelos superiores dentro Programa 
Os entrevistados concordaram ou não com essa afirmação, em grau que variava de zero para índice “nunca” e dez para índice "sempre”.

As respostas obtidas podem ser vistas na figura 6.44.

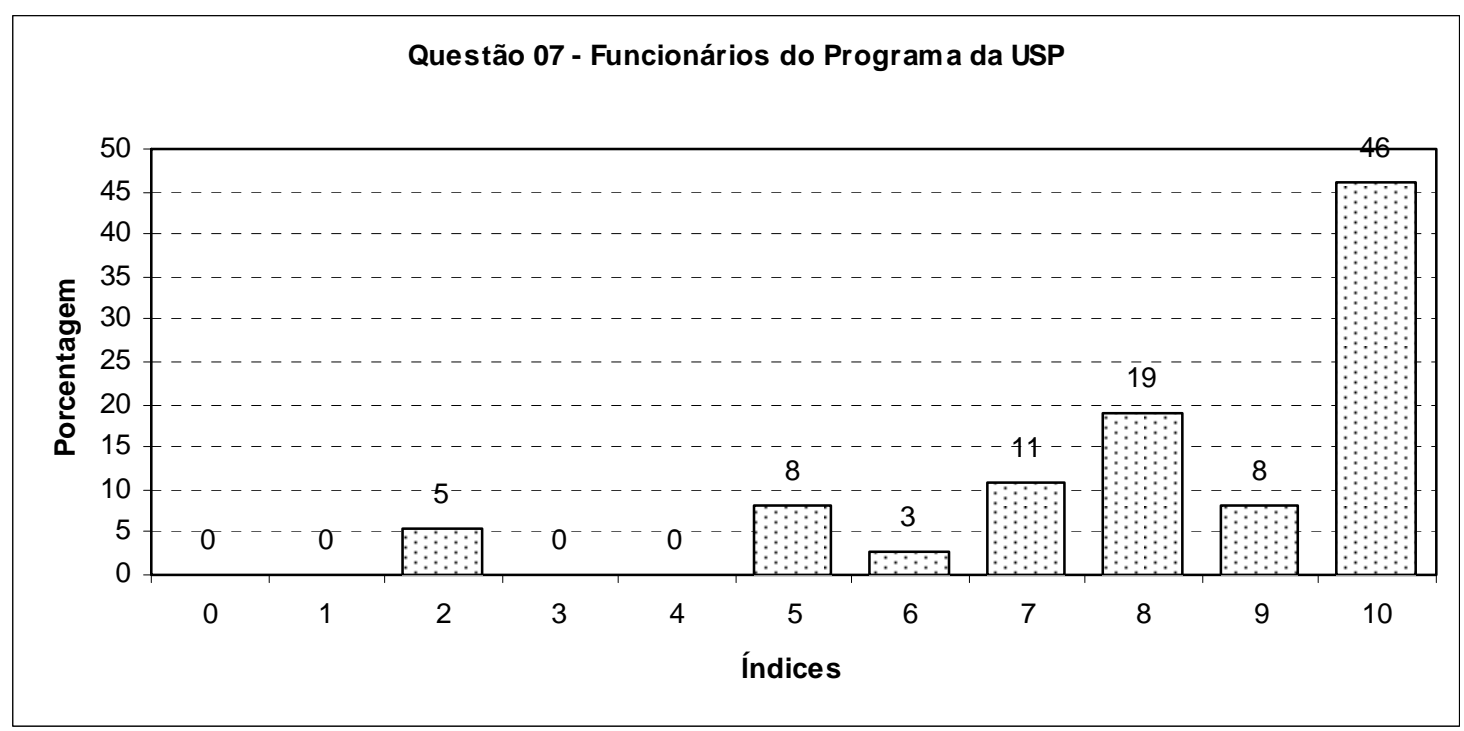

Figura 6.44: Respostas para questão 07 do questionário dos funcionários do Programa da USP

É importante frisar que os entrevistados que responderam "não" para a pergunta anterior, questão 06, não responderam essa questão, pois não conseguiriam opinar se são ouvidas ou não.

De acordo com os dados, na USP, 46\% dos funcionários do Programa sempre têm suas sugestões e/ou críticas ouvidas pelos superiores dentro do Programa, outros $38 \%$ quase sempre as tem ouvidas, $11 \%$ acham que são ouvidas de maneira moderada e $5 \%$ que quase nunca tem suas sugestões e/ou críticas ouvidas.

Como dito anteriormente, ter as críticas e/ou sugestões ouvidas pelo Programa é de grande importância para a combinação do conhecimento, pois o mesmo pode ser externalizado e não aproveitado. 
O resultado para os funcionários foi muito bom, mostrando que as sugestões e/ou críticas são ouvidas dentro do Programa.

A questão 08 do questionário teve a intenção de verificar se a pessoa está satisfeita com a função exercida no Programa.

Para isso a seguinte afirmação foi formulada:

- Estou satisfeito com minha função no Programa

Os entrevistados concordaram ou não com essa afirmação respondendo sim ou não.

As respostas obtidas podem ser vistas na figura 6.45 .

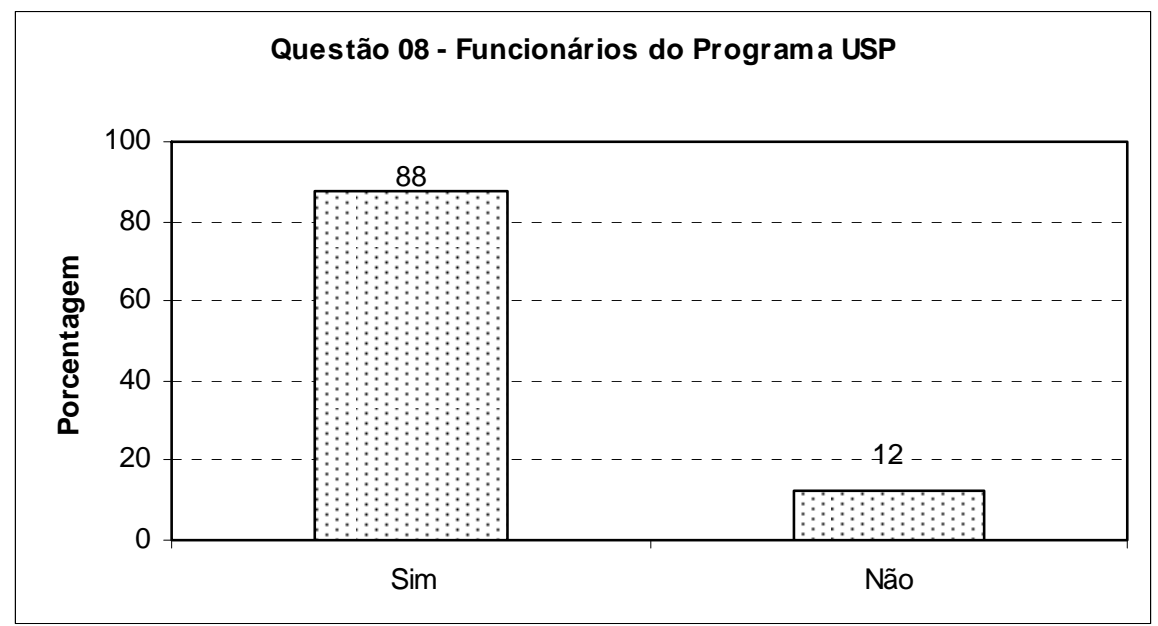

Figura 6.45: Respostas para questão 08 do questionário dos funcionários do Programa da USP

Na USP, $88 \%$ dos funcionários estão satisfeitos com a função no Programa e $12 \%$ não estão satisfeitos, o que mostra que a maioria dos funcionários está satisfeita com a função exercida no Programa.

A questão 09 do questionário teve a intenção de verificar como são as informações fornecidas aos funcionários. 
Para isso a seguinte afirmação foi formulada:

- As informações fornecidas pelos Programas são

Os entrevistados concordaram ou não com essa afirmação, em grau que variava de zero para índice “confusas” e dez para índice “claras”.

As respostas obtidas podem ser vistas na figura 6.46 .

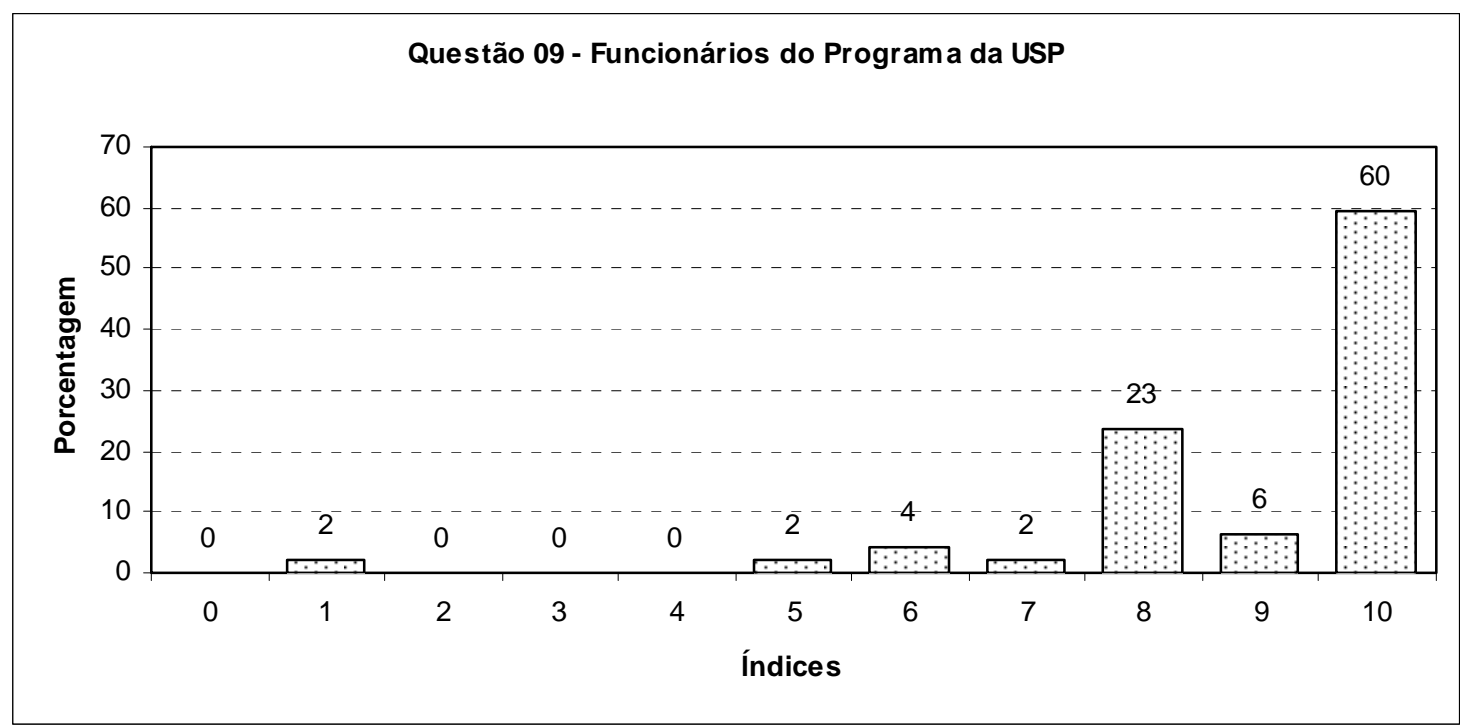

Figura 6.46: Respostas para questão 09 do questionário dos funcionários do Programa da USP

Na USP a avaliação dos funcionários do Programa foi a seguinte: $60 \%$ acham que as informações são muito claras, $33 \%$ que são claras, $6 \%$ razoavelmente claras e $2 \%$ pouco confusas.

A clareza das informações está em um nível aceitável para os funcionários do Programa, não demandando urgência na melhora.

A questão 10 do questionário teve a intenção de verificar a adesão com a iniciativa dos programas.

Para isso a seguinte afirmação foi formulada: 
- Em relação às iniciativas tomadas pelo Programa

Os entrevistados concordaram ou não com essa afirmação, em grau que variava de zero para índice “discordo” e dez para índice “concordo”.

As respostas obtidas podem ser vistas na figura 6.47.

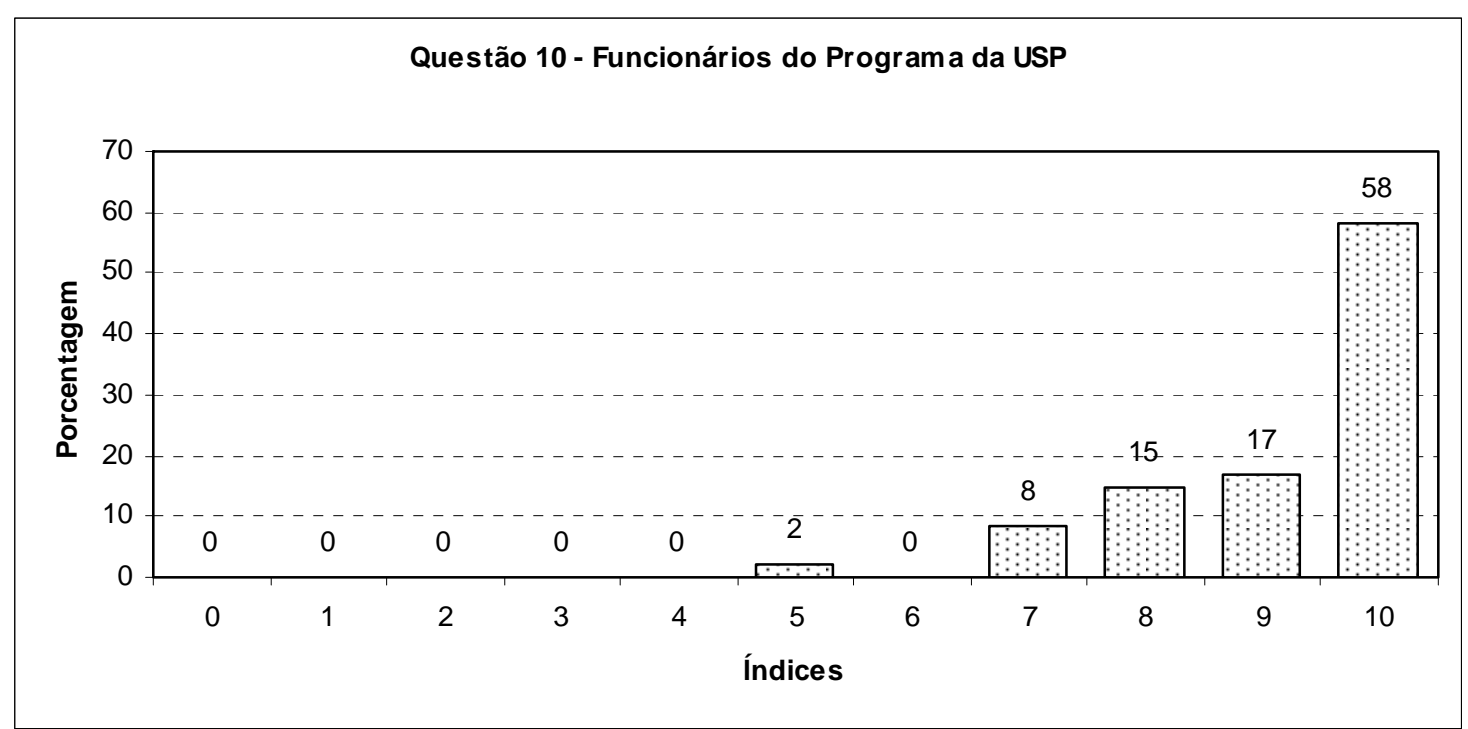

Figura 6.47: Respostas para questão 10 do questionário dos funcionários do Programa da USP

Na USP 58\% dos funcionários sempre concordam com as iniciativas tomadas pelo Programa, $40 \%$ quase sempre concordam e $2 \%$ concordam de forma moderada.

Isso nos revela uma ótima aceitação das iniciativas do Programa na USP.

A questão 11 do questionário teve a intenção de verificar se as pessoas estão interessadas no conhecimento oferecido ou se buscam o conhecimento. Para isso a seguinte afirmação foi formulada:

- Participo de palestras e eventos oferecidos pelo Programa

Os entrevistados concordaram ou não com essa afirmação, em grau que variava de zero para índice “nunca” e dez para índice "sempre”. 
As respostas obtidas podem ser vistas na figura 6.48 .

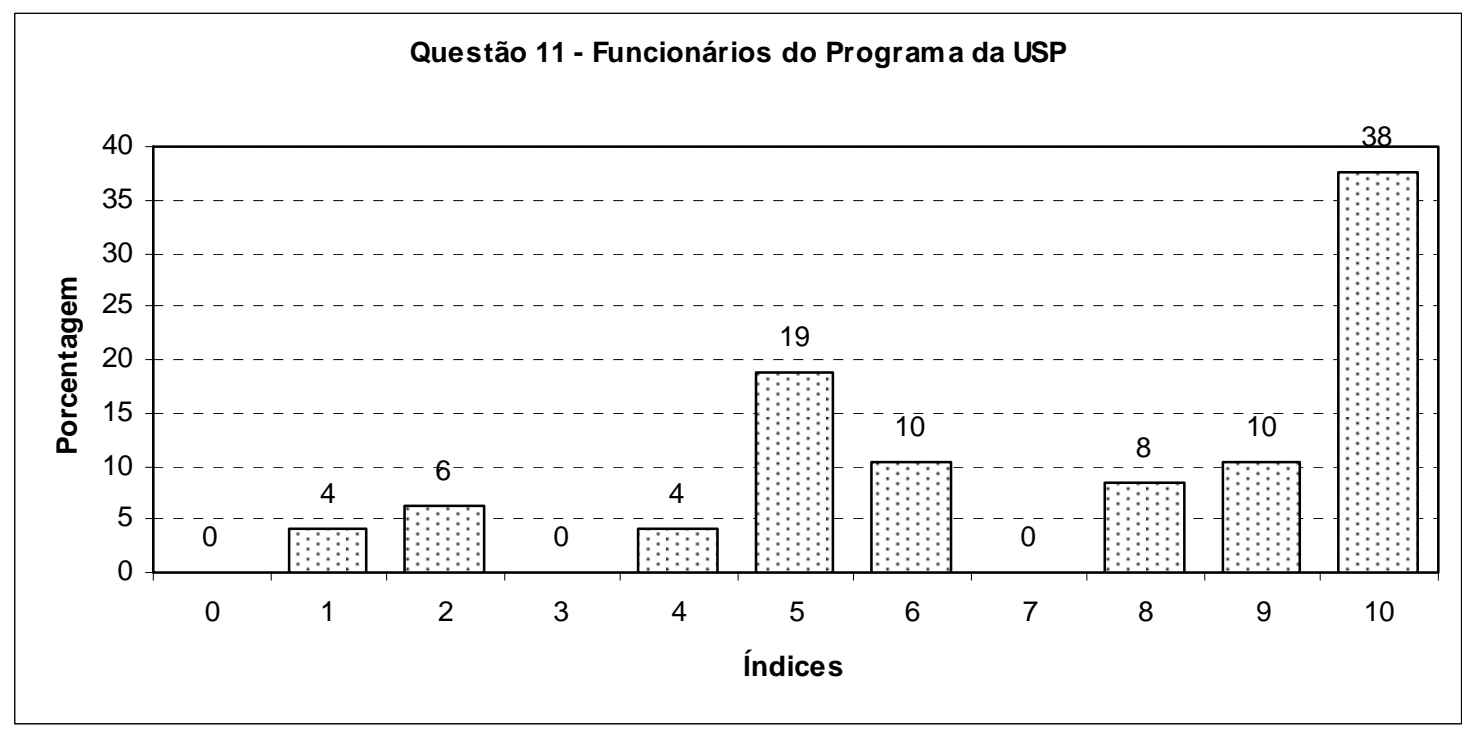

Figura 6.48: Respostas para questão 11 do questionário dos funcionários do Programa da USP

De acordo com os funcionários do Programa da USP, 38\% sempre participam de palestras e eventos do programa, 19\% quase sempre participam dos eventos e palestras, $33 \%$ participam de forma moderada e $10 \%$ quase nunca participam.

Isso mostra que grande parte dos funcionários do Programa participa das palestras e eventos oferecidos, buscando informações e conhecimento para exercer suas atividades dentro do mesmo.

A questão 12 do questionário teve a intenção de verificar se os Programas influenciam de alguma forma a relação dos gestores com as questões ambientais.

Para isso a seguinte afirmação foi formulada:

- O Programa influencia de alguma forma minha relação com as questões ambientais

Os entrevistados concordaram ou não com essa afirmação, em grau que variava de zero para índice "nunca” e dez para índice "sempre”. 
As respostas obtidas podem ser vistas na figura 6.49.

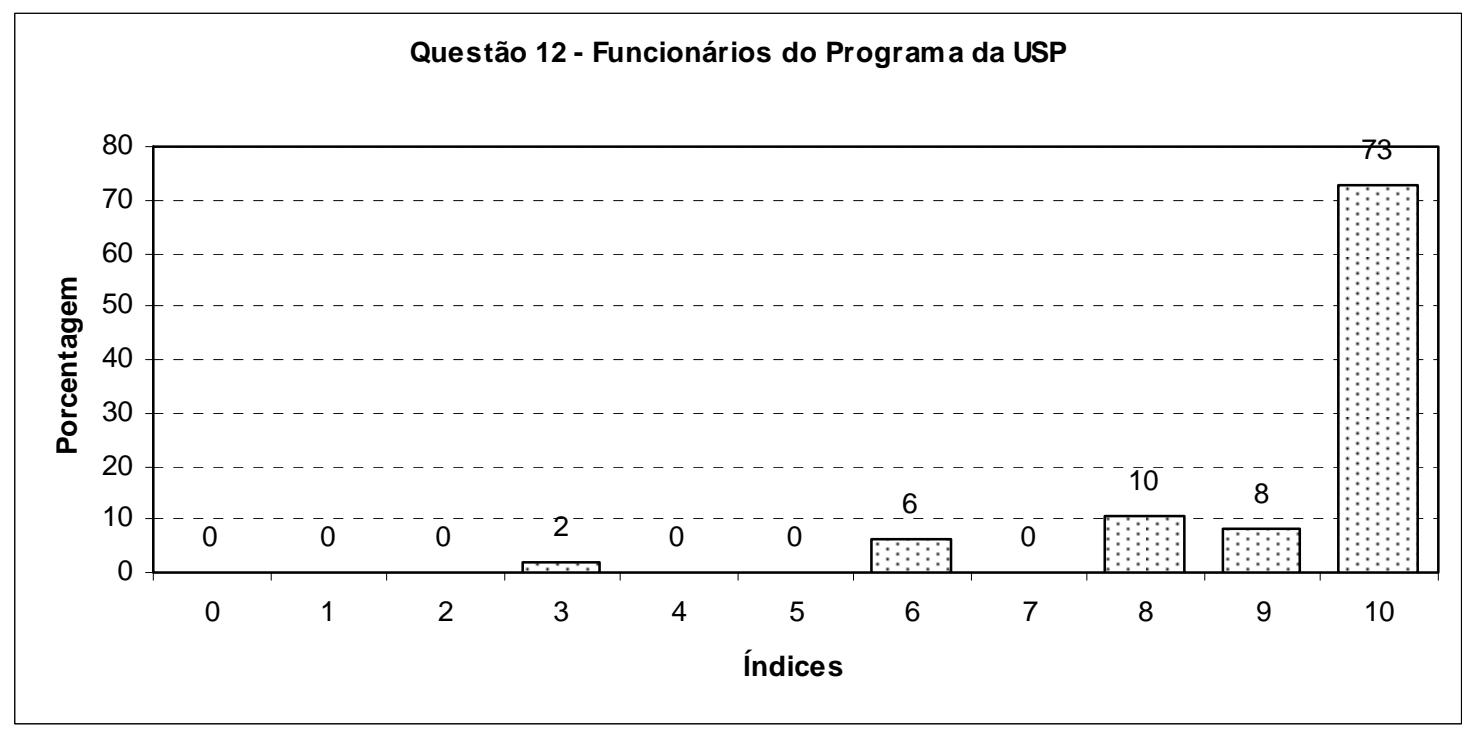

Figura 6.49: Respostas para questão 12 do questionário dos funcionários do Programa da USP

De acordo com a pesquisa, para $73 \%$ dos funcionários o Programa da USP sempre influencia de alguma forma as relações com as questões ambientais, para 19\% essa influência ocorre quase sempre, $6 \%$ acham que a influência é moderada e $2 \%$ que quase nunca são influenciados.

Com a finalidade de avaliar o questionário a seguinte questão foi colocada ao final do mesmo:

- Avalie somente o questionário

As respostas obtidas podem ser vistas na figura 6.50 . 


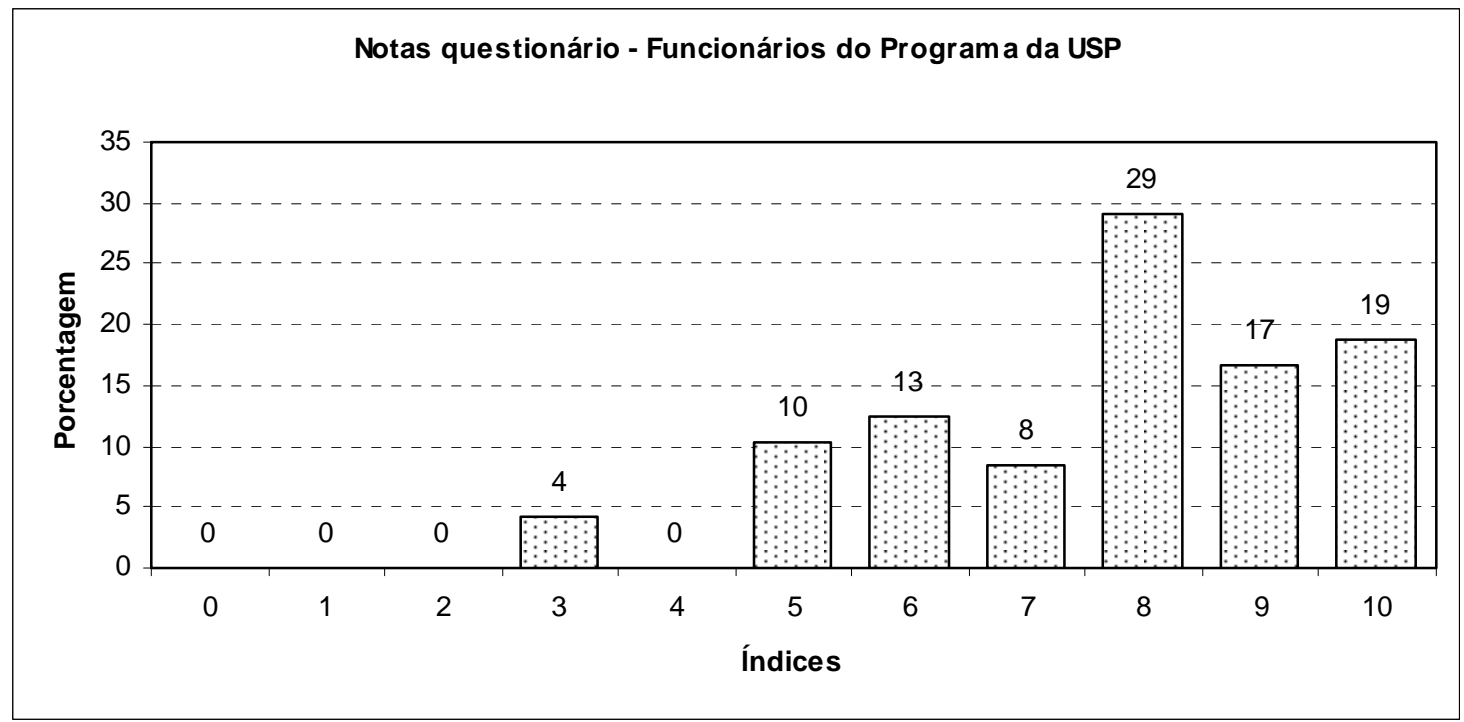

Figura 6.50: Respostas para as Notas do questionário dos funcionários do Programa da USP

A média das notas foi de aproximadamente oito (8), mostrando que o questionário foi bem aceito pelos funcionários do Programa.

Com a análise dos dados realizada, passa-se agora a discussão dos resultados obtidos. 


\section{GONGLUSO็局}

\section{1 - A LOGÍSTICA REVERSA NOS PROGRAMAS ESTUDADOS}

Como foi visto na Revisão Bibliográfica deste trabalho, a logística reversa não é só reciclagem, na verdade a reciclagem de recursos representa uma das alternativas dos canais reversos, que correspondem às etapas de retorno de bens de pós-consumo ao ciclo produtivo.

De acordo com Leite (2003), na composição da cadeia reversa o sistema de reciclagem agrega não só valor econômico, mas também valor ecológico, legal e logístico aos bens de pós-consumo, criando condições para que o material seja reintegrado ao ciclo produtivo, gerando uma economia reversa. Para que essa reintegração se realize, são necessárias as etapas de coleta, seleção, preparação e reciclagem industrial.

A tendência mundial da redução do ciclo de vida dos produtos gera, segundo Leite (2003), um aumento na quantidade de itens a ser manipulada nos canais de distribuição diretos e, consequentemente, nos canais reversos, e os antigos sistemas de retorno confundidos com o fluxo direto não são adequados a altos volumes de produtos. Daí a necessidade de planejamento desse fluxo reverso.

Nos programas estudados esse fluxo reverso é representado pela coleta de papel, que é o principal resíduo gerado, e também de metais, vidros e lâmpadas fluorescentes. Após o uso, esses materiais são descartados e recolhidos pela coleta seletiva de cada 
programa. Estes, por sua vez, repassam o material para cooperativas (intermediários) que revendem o material para indústrias de reciclagem.

No caso específico das lâmpadas fluorescentes a coleta seletiva dos programas as armazena e as encaminha diretamente para a indústria de reciclagem. $\mathrm{O}$ intermediário, nesse caso, é o próprio programa.

Para melhor visualização desse fluxo reverso dos programas, a seguir, é apresentado o fluxograma dos canais de distribuição na Figura 7.1. Em destaque o fluxo do canal reverso dos programas estudados. 


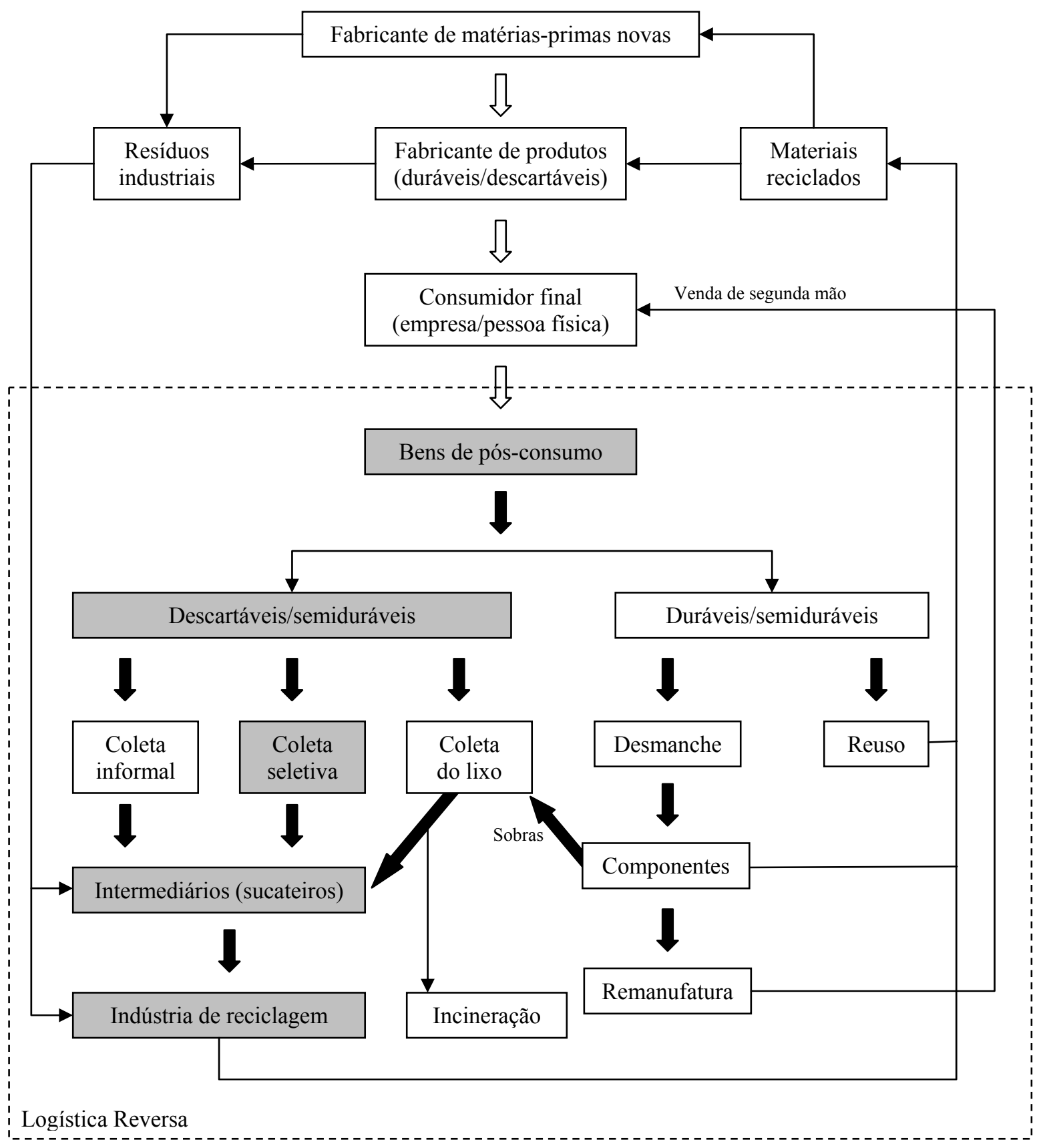

Figura 7.1: Canais de distribuição de pós-consumo: diretos e reversos Fonte: Adaptado de Leite (2003).

Desse modo, nota-se que os programas estudados se encaixam claramente no fluxograma dos canais de distribuição proposto por Leite (2003).

Como citado anteriormente nesse trabalho, de acordo com Carter e Ellram (1998), a Logística Reversa, se baseia hierarquicamente no princípio dos 3R's, que consiste em reduzir, reutilizar e reciclar, respectivamente, e só posterior disposição, seja 
com recuperação de energia (preferencialmente) ou não, o que se encaixa com as ações tomadas pelos programas da USP e UFSCar.

Assim os programas foram analisados de acordo com esses princípios.

\subsection{1 - REDUÇÃO DE RECURSOS}

A etapa de redução de recursos deve ser encarada como prioritária, pois através da diminuição do fluxo direto tem-se a diminuição do fluxo reverso. Esse princípio parte do pressuposto de Leite (2003), que o material que não é consumido não pode ser descartado.

Quando se obseva as iniciativas dos programas nota-se essa preocupação em algumas medidas adotadas.

Nos programas da USP e da UFSCar, a substituição dos copos descartáveis por canecas duráveis, tanto no RU como nas unidades e departamentos diminuiu muito a quantidade de copos descartáveis que eram usados diariamente, aproximadamente 500 mil por ano na USP. Além disso, os programas destinam os resíduos orgânicos compostáveis gerados nos campi para utilização como adubo na horta das Universidades, diminuindo a necessidade de compra de adubo.

O programa da USP ainda tomou outras ações para incentivar a redução do consumo como a impressão de documentos (teses e dissertações) em frente e verso como norma, o incentivo ao meio eletrônico de comunicação e divulgação de eventos e a promoção de campanhas educativas de combate ao desperdício de resíduos orgânicos no RU. 
Essas ações são eficazes na medida em que buscam que a minimização desses resíduos se torne habitual aos usuários e assim sejam levadas para outros locais de convívio desses usuários. Sendo assim, seria importante o programa da UFSCar tomar atitudes semelhantes ao do programa da USP, pois além de serem medidas de baixo ou nenhum custo, ajudam a reduzir o consumo.

\subsection{2 - REUTILIZAÇÃO DE RECURSOS}

Após a etapa de redução dos recursos os esforços e iniciativas se voltam para a reutilização, pois nem todos os recursos podem ser reduzidos e alguns ainda podem ser reutilizados como, por exemplo, o papel. Ainda que a diminuição da compra de papel seja significativa é praticamente impossível para uma Universidade deixar de utilizá-lo, assim, tanto no Programa da USP como da UFSCar são adotadas ações de educação para a reutilização do papel já utilizado, mas que ainda pode ser reutilizado para rascunho, diminuindo a quantidade de papel que precisa ser comprada.

No programa da USP existe também o incentivo a reutilização de certos tipos de embalagens como de vidros, plásticos e metais, o que diminui a quantidade desses materiais que seriam encaminhados para a reciclagem. Medidas como essas poderiam ser adotadas pelo programa da UFSCar já que não apresentou nenhuma iniciativa semelhante.

Outras iniciativas interessantes do programa da USP que poderiam ser incorporadas pelo programa da UFSCar são as realizações da "Feira da Sucata e da Barganha" e "Feira do Bixo" que incentivam a população e os alunos a reutilizarem materiais como livros, objetos usados e materiais escolares. Além de serem medidas educacionais e de incentivo a reutilização de recursos, tais feiras reduzem o fluxo direto e reverso de materiais nas universidades. 


\subsection{3 - RECICLAGEM DE RECURSOS}

A reciclagem de recursos deve ser encarada como a última alternativa da filosofia dos 3R's, só utilizada quando são esgotadas todas as possibilidades de redução e reutilização dos recursos.

O principal resíduo gerado nas Universidades estudadas é o papel, que é coletado em caixas de papelão ou cestas plásticas espalhadas pelas salas de todas as unidades, salas de aula e departamentos. Esse papel é posteriormente recolhido pela equipe terceirizada de limpeza, encaminhado a central de armazenamento nas universidades e depois recolhido pelas cooperativas de catadores de lixo.

Na USP, os demais recicláveis como metais, vidros e plásticos são recolhidos utilizando um coletor único, como já visto anteriormente, que estão em pontos estratégicos dentro das unidades. A UFSCar não conta com esses coletores nas unidades, mas possui um PEV que supre toda essa necessidade no campus. O processo de recolhimento destes recicláveis é o mesmo do papel, sendo que, como são recolhidos juntos, também são pesados dessa forma. Isso se justifica pela pequena quantidade gerada desses recicláveis e, também, pelo fácil manuseio. A única orientação feita para o descarte desses tipos de materiais é que estejam limpos, secos e livres de resíduos orgânicos, o que possibilita um menor gasto de água e energia para o processo de reciclagem.

O programa da UFSCar poderia alocar coletores nas suas unidades para que as pessoas não precisem se deslocar para fazer o descarte adequado dos descartáveis. Deve-se lembrar que o campus estudado da UFSCar possui uma grande extensão territorial, o que dificulta que as pessoas façam o descarte dos recicláveis no PEV. 
Coletores estrategicamente localizados contribuiriam para que os materiais recicláveis não fossem para o lixo comum.

Em relação às lâmpadas fluorescentes, que são armazenadas em locais arejados e posteriormente encaminhadas a uma indústria de reciclagem (APLIQUIM), entende-se que as universidades estudadas, como centros de tecnologia, deveriam desenvolver métodos ou técnicas de reciclagem desse tipo de material e, assim, além do ganho tecnológico deixariam de pagar a terceiros para que a reciclagem seja feita.

Assim, depois dessas considerações realizadas, pode-se observar que as atividades, processos e procedimentos de Logística Reversa presente nos Programas analisados contribuem no gerenciamento dos resíduos e que certas ações, se tomadas, poderiam melhorar ainda mais os índices de reciclagem nos programas.

\section{2 - A GESTÃO DO CONHECIMENTO NOS PROGRAMAS ESTUDADOS}

Nesse subitem a gestão do conhecimento será analisada nos programas e, para isso, deve-se destacar alguns resultados relevantes da pesquisa, são eles:

- Gestores

1. Ausência de alunos de graduação no quadro de gestores de ambos os programas;

2. A maioria dos gestores sempre observa melhorias nos processos internos dos programas;

3. Os cursos de aprendizado são oferecidos em bom número pelos programas; 
4. Na UFSCar o acesso às informações do programa é razoavelmente fácil, enquanto que na USP é de fácil acesso;

5. O conhecimento gerado nos programas é armazenado;

6. Na UFSCar a difusão do conhecimento apresenta falha;

7. Em ambos os programas o conhecimento criado é aplicado;

8. Sempre contribuem com a coleta seletiva na Universidade e fora dela;

9. Na UFSCar a participação com sugestões e/ou críticas deveria ser melhorada, na USP a situação é boa;

10. As sugestões e/ou críticas são ouvidas de maneira satisfatória;

11. As mudanças na gestão do programa da USP poderiam ser mais freqüentes;

12. As mudanças ocorrem de acordo com as iniciativas dos programas;

13. Na UFSCar, a participação em palestras poderia ser maior;

14. O programa influencia os gestores nas questões ambientais.

- Clientes

1. Compostos, em sua maioria, por estudantes de graduação e pósgraduação;

2. Na UFSCar o programa é pouco conhecido; 
3. Em ambos os programas a quantidade de cursos de aprendizado é insuficiente;

4. A participação em palestras e eventos dos programas é muito pequena;

5. O acesso às informações do programa da UFSCar é carente;

6. A maioria das informações é obtida por meio de folhetos;

7. Baixo comprometimento dos clientes com a coleta seletiva dos materiais;

8. A maioria não participa com sugestões e/ou críticas aos programas;

9. As sugestões e/ou críticas aos programas são pouco ouvidas;

10. As informações fornecidas pelos programas são de entendimento fácil;

11. E estão de acordo com as iniciativas dos programas;

12. O programa influencia os clientes nas questões ambientais.

- Funcionários

1. Compostos, em sua maioria, por funcionários da USP e estudantes de graduação;

2. Todos conhecem o programa;

3. Cerca de $25 \%$ acreditam receber poucos cursos de aprendizado;

4. Têm acesso as informações do programa;

5. Contribuem com a seleta coletiva no campus; 
6. Aplicam o conhecimento aprendido fora da Universidade;

7. Cerca $25 \%$ não participa com sugestões e/ou críticas;

8. Acreditam que as sugestões e/ou críticas são ouvidas;

9. Estão satisfeitos com suas funções dentro do programa;

10. Acreditam que as informações fornecidas pelo programa são claras;

11. Concordam com as iniciativas tomas pelo programa;

12. A participação em palestras e eventos oferecidos pelo programa deveria ser maior;

13. Acreditam que o programa os influencia na relação com as questões ambientais.

A partir dessas informações pode-se fazer algumas ponderações sobre a gestão do conhecimento nos programas.

A primeira e muito importante é que não existem estudantes de graduação entre os gestores do programas e, como dito anteriormente, essa situação é negativa, pois pode dificultar que a visão do aluno seja levada até a gestão dos programas, que problemas rapidamente identificados pelos alunos, que são o público alvo dos programas, sejam resolvidos e que necessidades observadas pelos mesmos sejam atendidas. Além disso, todo o envolvimento da organização é necessário para que o processo de criação do conhecimento se torne eficaz.

Para se analisar o processo de criação de conhecimento nos programas estudados, foram identificadas as questões dos questionários aplicados que mostram os 
processos de socialização, externalização, combinação e internalização. Sendo assim, tem-se a Tabela 7.1.

Tabela 7.1. Questões relacionadas ao processo de criação do conhecimento.

\begin{tabular}{rccc}
\hline & \multicolumn{3}{c}{ Questão do Questionário } \\
\cline { 2 - 4 } & Gestores & Clientes & Funcionários \\
\hline Socialização & 2 e 15 & 2 e 3 & 2 e 11 \\
Externalização & 9,10 e 11 & 7 e 8 & 6 e 7 \\
Combinação & 1 e 9 & 7 & 6 \\
Internalização & 7 e 8 & 5 e 6 & 4 e 5 \\
\hline
\end{tabular}

Assim pode-se identificar a deficiência no processo de criação do conhecimento.

Tanto no programa da USP como no da UFSCar, o problema da socialização se encontra na quantidade de cursos oferecidos. Os cursos representam a oportunidade de clientes e funcionários entrarem em contato com os programas e com o conhecimento neles armazenado, para que haja uma troca de experiências e o conhecimento tácito de cada um seja compartilhado. Isso pode ser verificado quando os clientes deixam claro que um maior número de cursos poderia ser oferecido e quando clientes e funcionários mostram que sua participação em palestras e eventos ofertados pelos programas é baixa.

A externalização é importante para que o conhecimento tácito do indivíduo possa se tornar conhecimento por outro indivíduo. Nesse caso ambos os programas permitem que os indivíduos exponham suas opiniões. O problema encontrado foi a baixa participação dos clientes na externalização. Os clientes são parte importante na criação do conhecimento, pois detém visão muito próxima dos problemas encontrados assim, o canal de sugestões poderia ser intensificado e a troca de informações estimulada. 
A combinação, que é a criação de novos conhecimentos através da mescla de conhecimentos externalizados pode ser observada principalmente na primeira questão do questionário dos gestores, onde relatam claramente que sempre observam melhorias nos processos internos dos programas. Essas melhorias nada mais são do que novos conhecimentos que foram gerados e aplicados no programa. Também se pode notar a presença da combinação na participação com sugestões e/ou críticas aos programas, já que sugestões e críticas são novos conhecimentos e, nesse caso, há de se ressaltar novamente que se deve estimular toda a organização a participar com sugestões e/ou críticas.

A internalização nada mais é que a absorção ou assimilação do conhecimento e pode-se identificá-la observando se as pessoas utilizam o conhecimento aprendido com os programas em seu cotidiano. Assim, de acordo com os resultados obtidos se observa que gestores e funcionários incorporaram o conhecimento aprendido em seus cotidianos, já os clientes, embora tenham acesso ao conhecimento, apresentam deficiência na internalização do mesmo, talvez devido à falta de comprometimento com os programas o conhecimento caia em desuso.

Assim se observa que algumas medidas precisam ser adotadas para que a criação do conhecimento se torne parte da cultura da organização. Entre elas se deve citar o envolvimento, comprometimento e apoio à criação do conhecimento de todos os gestores. Há a necessidade de integrar alunos de graduação aos gestores, para que a gestão enxergue a organização ou o programa de vários modos e, também, para que caminhos sejam encurtados. É necessário que se estimule a participação de clientes e funcionários em palestras e eventos e que esses sejam oferecidos em maior número ou mais divulgados. 
A divulgação é um ponto importante a ser abordado, mas não só a divulgação do programa, a divulgação das metas e resultados obtidos é interessante para que haja o estímulo das pessoas inseridas na organização em participar do projeto.

$\mathrm{Na}$ UFSCar, onde cerca de $65 \%$ dos clientes não conhecem o programa, se encontra a situação mais crítica. Os gestores do programa têm que promover a divulgação do programa e a informação sobre o mesmo, pois pessoas não podem contribuir com o programa se não o conhecem. Com a implantação do Programa de Educação Ambiental por parte da UFSCar esse quadro tenderá a mudar.

Portanto se observa que medidas simples e pouco dispendiosas podem ser adotadas para que a criação do conhecimento se torne parte da cultura dos programas estudados.

O fluxo do conhecimento, quando se pensa em conhecimento aplicado, criado, armazenado e distribuído para todos os integrantes dos programas apresenta um "gap" ou salto qualitativo entre o conhecimento aplicado, criado e armazenado e o conhecimento distribuído, já que se encontram problemas de divulgação dos programas em ambas as universidades estudadas. Esse problema ocorre principalmente na UFSCar, onde $66 \%$ não conhecem o programa e dos $34 \%$ que o conhecem, somente $46 \%$ acreditam ter acesso às informações sobre o programa, ou seja, somente $30 \%$ do público alvo do programa da UFSCar possui informações sobre o programa. Já na USP cerca de $60 \%$ do público alvo tem acesso as informações sobre o programa.

Para analisar o fluxo do conhecimento, na tabela 7.2 abaixo, a relação entre as questões e as questões chaves do fluxo do conhecimento são apresentadas. 
Tabela 7.2. Questões relacionadas ao fluxo do conhecimento.

\begin{tabular}{cccc}
\hline & \multicolumn{3}{c}{ Questão do Questionário } \\
\cline { 2 - 4 } & Gestores & Clientes & Funcionários \\
\hline Compartilhamento & $9,10,11$ e 15 & 3,7 e 8 & 6,7 e 11 \\
Criação & 1 e 9 & 7 & 6 \\
Armazenamento & 4 & --- & --- \\
Aplicação & $1,6,7$ e 8 & 5 e 6 & 4 e 5 \\
Difusão & 2,3, e 5 & 2,4 e 9 & 2,3 e 9 \\
\hline
\end{tabular}

Assim, de acordo com os resultados, pode-se notar que algumas etapas do fluxo do conhecimento precisam ser melhoradas.

No caso do compartilhamento, principalmente para os clientes, atitudes que estimulem a participação em palestras e eventos dos programas e com sugestões e/ou críticas precisam ser tomadas, já que o compartilhamento de experiências e de conhecimento é essencial para que novos conhecimentos sejam criados. Além disso, se nota que os clientes pouco participam com sugestões e/ou críticas com os programas, indicando que não compartilham seus conhecimentos, o que seria outro ponto a ser estimulado.

Observa-se a criação do conhecimento através das melhorias e indiretamente através das sugestões aos programas, já que sugestões são conhecimentos que são externalizados. Assim, embora os resultados apontem que os gestores criam conhecimento, isso não ocorre para os clientes e funcionários. Não é saudável para uma organização somente os gerentes, ou gestores no caso estudado, serem responsáveis pela criação do conhecimento, pois dificulta que a visão de baixo da organização seja observada. 
Armazenar o conhecimento é importante, pois permite que se crie um banco de dados, facilitando a busca por conhecimentos já criados e ações tomadas, evitando a perda tempo na criação de algo que já foi criado anteriormente e, também, permitindo que o conhecimento armazenado seja difundido posteriormente. Nesse caso os gestores de ambos os programas acham que os dados são armazenados. É difícil, senão impossível saber a opinião dos clientes e funcionários acerca do armazenamento do conhecimento, pois esse fica ao cargo dos gestores.

A aplicação do conhecimento nada mais é do que colocar em prática ou em uso o conhecimento criado na organização. Desde modo, se verifica que os gestores e funcionários aplicam o conhecimento tanto no próprio programa e na universidade, como fora dela, o que contribui com a difusão do conhecimento que será posteriormente discutida. Os clientes não aplicam massivamente o conhecimento aprendido, nem dentro, nem fora da universidade, o que indica falta de comprometimento com os programas, já que eles possuem o conhecimento e não o aplicam.

Em relação à difusão do conhecimento nota-se alguma disparidade de informações. Enquanto os gestores de ambos os programas acreditam que são oferecidos cursos a comunidade dos campi, que o acervo de informações é de fácil acesso e que o conhecimento é difundido entre os envolvidos, os clientes e funcionários afirmaram que necessitam de mais cursos, pois esses são oferecidos em pouca quantidade, mas julgam que as informações fornecidas são claras e que tem acesso à elas com exceção dos clientes da UFSCar que, em sua maioria, disseram não ter acesso as informações.

Para o quadro encontrado, algumas ações são necessárias para diminuir os "gaps" e os problemas encontrados entre as classes estudadas. Entre eles se destacam: 
1. A maior divulgação dos programas, especialmente da UFSCar, para que todos os ingressantes da comunidade universitária sejam atingidos;

2. Maior número de palestras e eventos ofertados pelos programas, procurando estimular o compartilhamento do conhecimento e o comprometimento com os ideais do programa; e

3. Participação de estudantes de graduação na tomada de decisão, o que leva a visão dessa classe (clientes) para a tomada de decisão e ajuda no comprometimento da classe com os ideais do programa.

Com essas medidas e o comprometimento da organização na criação do conhecimento, acredita-se que o ganho nos programas seria significativo.

\section{3 - CONCLUSÕES FINAIS}

A Logística Reversa se mostrou útil para avaliar a hierarquia de atuação dos programas em relação aos cuidados ambientais. Ambos os programas apresentaram similaridades no processo reverso, mas a grande diferença notada entre os programas ficou na divulgação dos mesmos. Na USP/São Carlos o programa de reciclagem é mais difundido no campus do que o programa da UFSCar é no seu respectivo campus.

O aspecto da divulgação seria o principal ponto a ser atacado pela administração do Programa de Reciclagem da UFSCar, já que, pelos dados obtidos, aproximadamente $65 \%$ do público-alvo não conhece o programa.

Outros pontos a serem melhorados no Programa de Reciclagem da UFSCar são: o aumento de campanhas educacionais, o incentivo a atividades relacionadas à 
reutilização de materiais e a criação de projetos de pesquisa e desenvolvimento como os existentes na USP.

Um ponto importante a ser destacado nos Programas estudados é que ambos possuem a coleta seletiva de produtos recicláveis (papéis, vidros, metais e plásticos) e que o processo de descontaminação das lâmpadas fluorescentes é custeado pela própria universidade. Há, ainda, o incentivo na destinação final dos materiais compostáveis, como adubos para as hortas que as próprias universidades possuem.

Em relação à Gestão do Conhecimento, apesar da exaustiva análise dos dados, essa ferramenta empresarial se mostrou bastante útil para a identificação de falhas ou "gaps" no fluxo do conhecimento de instituições com intuito educacional. Análise essa realizada somente utilizando-se questionários.

Nota-se que o fluxo de conhecimento compreendido por compartilhamento, criação, aplicação, armazenamento e distribuição tem que ser equilibrado e ter fluidez. Se somente uma das etapas falhar, todo o ciclo de criação de novos conhecimentos fica prejudicado e incompleto. Desse modo, as ações já mencionadas na etapa de análise dos dados têm que ser tomadas para equilibrar o fluxo de conhecimento.

Outra questão a ser observada é a disparidade de informações entre as classes estudadas, ou seja, enquanto os gestores do programa têm uma opinião, os clientes têm uma divergente. Observa-se isso em relação a quantidade de cursos oferecidos pelos Programas onde os gestores afirmaram que a quantidade é suficiente e os clientes acham que é insuficiente. 
Ainda, essa pesquisa teve o intuito de contribuir para a melhoria dos programas de reciclagem estudados. Espera-se que de posse dos dados, resultados obtidos e análise crítica, melhorias possam ser realizadas na estrutura dos programas.

Finalmente, espera-se que a pesquisa estimule não somente outros programas de reciclagem, mas também outras instituições, para que essas vejam a Gestão do Conhecimento como ferramenta fundamental para o crescimento organizacional.

\section{4 - CONSIDERAÇÕES FINAIS}

Através da comparação entre os Programas de Reciclagem da USP Campus São Carlos e da UFSCar Campus São Carlos, utilizando os conceitos de Logística Reversa e Gestão do Conhecimento, buscou-se observar as semelhanças e diferenças entre ambos e, assim, identificar as melhores práticas e sugerir algumas mudanças com o intuito da melhoria.

Em relação aos Programas analisados procurou-se respeitar o caráter educacional e não somente analisar o aspecto técnico, pois estes visam basicamente à conscientização das pessoas em relação ao uso de materiais e produtos.

A Gestão do Conhecimento se mostrou eficaz nesse processo, pois possibilitou identificar pontos deficientes na organização e processos dos programas em relação ao fluxo de conhecimento e a Logística Reversa possibilitou verificar se as prioridades existentes nos programas estão de acordo com as operações que a caracterizam.

O estudo se fundamenta no principal objetivo dos Programas de Reciclagem, o objetivo educacional. Educação não só envolve difusão do conhecimento, mas também compartilhamento, criação, armazenamento e aplicação, que são objetos de estudo da Gestão do Conhecimento como citado anteriormente. Outro fundamento para esse 
estudo são as novas exigências do público-alvo e as novas legislações ambientais, também na necessidade de ganho em imagem corporativa e, embora não seja o objetivo principal, o âmbito econômico não pode ser esquecido, pois todos esses processos envolvem a criação do conhecimento.

\section{5 - RECOMENDAÇÕES PARA TRABALHOS FUTUROS}

Para melhorar o método utilizado e resultados apresentados, algumas observações são necessárias:

1. Analisar novamente os programas após as melhorias propostas serem implantadas e comparar os dados obtidos com os apresentados nesse trabalho.

2. Simplificar o questionário visando uma análise de dados mais simples, provavelmente modificando a forma de resposta, considerando somente cinco opções de resposta.

3. Estudar os outros campi da USP (São Paulo, Ribeirão Preto, Piracicaba, Pirassununga e Bauru) e UFSCar (Sorocaba e Araras) e comparar com os resultados obtidos nesta pesquisa para verificar as diferenças entre os diversos programas.

4. Analisar novamente o programa de reciclagem da UFSCar, campus São Carlos, após a implantação do PEAm. 


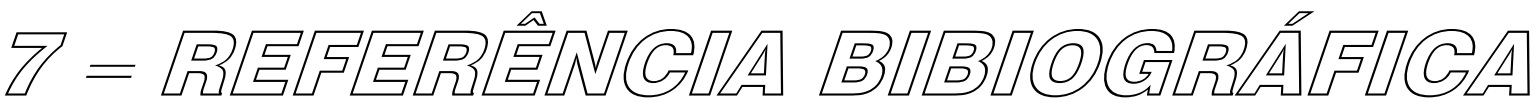

ALMEIDA, D. A. et al. (2006). Gestão do Conhecimento na Análise de Falhas: Mapeamento de Falhas através de Sistema de Informação. Prod., São Paulo, v. 16, n. 1. Disponível $\quad$ em: $\quad<$ http://www.scielo.br/scielo.php?script=sci_arttext\&pid=S010365132006000100014\&lng=pt\&nrm=iso>. Acesso em 28 de novembro de 2006.

ANTONIO, L. de Q. Impacto do programa de capacitação no ambiente virtual: Estudo de caso de uma rede de professores. Campinas - SP. 2005.

BALlOU, R. H. Gerenciamento da Cadeia de Suprimentos: Planejamento, Organização e Logística Empresarial. 4. ed. Porto Alegre: Bookman. 2001.

BARBIERE, J. C.; DIAS, M. (2002). Logística Reversa como Instrumento de Programas de Produção e Consumo Sustentáveis. Revista Tecnologística, São Paulo, ano VI, n. 77, abril/2002.

BOWERSOX, D. J.; CLOSS, D. J. Logística empresarial: o processo de integração da cadeia de suprimento. São Paulo: Atlas. 2001.

CÂNDIDO, G. A.; N. M. de ARAÚJO (2003) As tecnologias de informação como instrumento de viabilização da gestão do conhecimento através da montagem de mapas cognitivos. Ciência da Informação. v. 32, n. 3, p. 38-45.

CANONGIA, C.; DALCI M. S.; MARCIO M. S.; MAURO Z. (2004) Foresight, inteligência competitiva e gestão do conhecimento: instrumentos para a gestão da inovação. Gestão \& Produção. v. 11, n. 2, p. 231-238. 
CARTER, C. R.; ELLRAM, L. M. (1998). Reverse Logistics: A review of the literature and framework for future investigation. Journal of Business Logistics, vol.19, n.1, p.85-103.

COORDENADORIA ESPECIAL PARA O MEIO AMBIENTE (2002). Universidade

7- Referências ənvolvido pela CEMA - Coordenadoria Especial para o Meio Ambiente. Disponível em: <http://www.ufscar.br/ ugr/cema> . Acesso em 13 de novembro de 2006.

COUNCIL OF LOGISTICS MANAGEMENT (1993). Reuse and Recycling Reverse Logistics Opportunities. Illinois: Council of Logistics Management.

DAVENPORT, T. H. (2001). Ecologia da Informação. Tradução de Bernadette Siqueira Abrão. 3. ed. São Paulo: Futura.

_., PRUSAK, Laurence.(1998) Conhecimento empresarial:como as organizações gerenciam seu capital intelectual,métodos e aplicações práticas. Rio de Janeiro: Campus.

FARIA, A. C.; COSTA, M. F. G. (2005). Gestão de Custos Logísticos. São Paulo: Atlas.

KAPLAN, R. S.; NORTON, D. P. (1997). A Estratégia em Ação: Balanced Scorecard. Tradução de Luiz Euclydes Trindade Frazão Filho.12. ed. Rio de Janeiro: Campus. . (2001). Organização Orientada para a Estratégia. Rio de janeiro: Campus.

LACERDA, L. (2002). Logística reversa: Uma visão sobre os conceitos básicos e as práticas operacionais. Revista Tecnologística, Janeiro/2002. 
LEDEL, L. C. Gerenciamento do Conhecimento Aplicado a Fins Educacionais. Campinas - SP. 2005.

LEITE, P. R. Logística Reversa: Meio Ambiente e Competitividade. São Paulo: Prentice Hall. 2003.

LEME, P. C. S. (2005). Anuário USP Recicla - São Carlos 2005. Universidade de São Paulo, Programa USP Recicla - Campus São Carlos.

LIMA, L. M. Q. Tratamento de lixo. São Paulo: Hemus. 1985.

LINKE, J. C. A gestão do conhecimento como ferramenta de desenvolvimento das empresas da indústria moveleira da região de São Bento do Sul - SC. Florianópolis - SC. 2001.

LUZ, F. X. R. (1981). Aterro sanitário, características, limitações, tecnologia para a implantação e a operação. CETESB. São Paulo.

MAIA, P. R. de S.; FRANZ R. N.; JOÃO A. G. de A.; DANIELLE A. da S. (2005) Sistema de gestão do conhecimento para Rede Nacional de Bancos de Leite Humano. Ciência \& Saúde Coletiva. v. 10, p. 121-132.

MARQUES, C. S. A.; FERREIRA, I. V. L.; AGUIAR, E. M. (2002). A Logística Reversa e o Gerenciamento de Resíduos Sólidos. In: VI Seminário Nacional de Resíduos Sólidos - ABES - Trabalhos Técnicos. Gramado, RS.

PERROTTI, E. Estrutura Organizacional e Gestão do Conhecimento. São Paulo - SP . 2004.

POPADIUK, S. et al. (2006). Arquitetura da Informação e Mensuração do 
Desempenho: Um Estudo na Indústria de Artefatos e Utensílios de Plásticos no Estado de São Paulo. Gest. Prod., São Carlos, v. 13, n. 1.Disponível em: $<\mathrm{http}: / /$ www.scielo.br/scielo.php?script=sci_arttext\&pid=S0104$530 X 2006000100014 \& \operatorname{lng}=$ pt\&nrm=iso $>$. Acesso em 28 de novembro de 2006.

PROGRAMA USP RECICLA (2003). Universidade de São Paulo. Desenvolvido pela CECAE - Coordenadoria Executiva de Cooperação Universitária e de Atividades Especiais. Disponível em: <http://www.cecae.usp.br/recicla/site>. Acesso em 09 de outubro de 2006.

RODRIGUES, G. G.; PIZZOLATO , N. D. (2004). Logística Reversa dos Produtos de Pós-Venda no Segmento de Lojas de Departamento. In: Anais do XVIII Congresso de Pesquisa e Ensino em Transportes. Associação Nacional de Pesquisa e Ensino em Transportes, ANPET, Florianópolis, v. 02, pg. 1201 - 1212.

ROGERS, D. S.; TIBBEN-LEMBKE, R. S. (1998). Going Backwards: Reverse Logistics Trends and Practices. Universidade of Nevada, Reno. Disponível em: $<$ http://www.rlec.org/reverse.pdf $>$. Acesso em 12 de junho de 2006.

SANTOS, I. C. Um modelo estruturado de gestão do conhecimento em indústrias de base tecnológica: Estudo de caso de uma empresa do setor aeronáutico. São Paulo - SP. 2004.

SILVA, S. L. da (2002) Informação e competitividade: a contextualização da gestão do conhecimento nos processos organizacionais. Ciência da Informação. v. 31, n. 2, p. 142151.

. (2004) Gestão do Conhecimento: uma revisão crítica orientada pela abordagem da criação do conhecimento. Ciência da Informação. v. 33. n. 2. p. 143-151. 
SELlTIZ, C.; WRIGHTSMAN, L. S.; COOK, S. W. Métodos de pesquisa nas relações sociais. - São Paulo: EPU. 1987.

TRISKA, R. Proposta de uma base de dados institucional para a gestão do conhecimento. Florianópolis - SC. 2001.

UNIDADE DE GESTÃO DE RESÍDUOS (2006). Dados Referentes a Coleta Seletiva na Universidade Federal de São Carlos no período de 2002 a 2006. Desenvolvido pela UFSCar - Universidade Federal de São Carlos sob Coordenação da CEMA - Coordenadoria Especial para o Meio Ambiente. Não publicado.

VON KROGH, G.; ICHIJO, K.; NONAKA, I. (2001) Facilitando a criação de conhecimento: reinventando a empresa com o poder da inovação contínua. - Rio de Janeiro: Campus. 


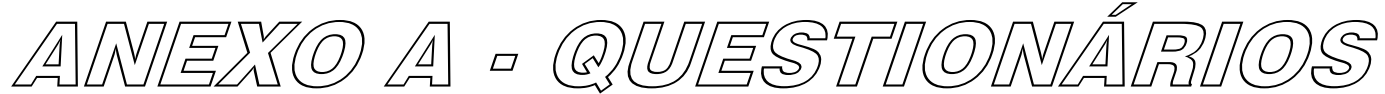

$\mathrm{C}$ $/ 2007$

\section{QUESTIONÁRIO (USP-SÃO CARLOS)}

DATA: $/ 05 / 2007$

Prezado(a) Senhor(a), este questionário foi elaborado com a finalidade de levantar dados a respeito do Programa de Reciclagem USP Recicla, da USP - São Carlos, no período de 07 a 12 de maio de 2007. Este instrumento faz parte de duas pesquisas de mestrado da Escola de Engenharia de São Carlos, do Departamento de Transportes, na área de Planejamento e Operação de Sistemas de Transportes.

Respondendo ao questionário você estará colaborando para a melhoria do programa USP Recicla dessa Universidade, então, por favor, responda de maneira mais fiel possível à sua impressão em relação ao programa abordado.

\section{Gênero}

Feminino

Masculino

\section{Cargo}

Aluno Graduação

Aluno Pós-Graduação

Docente

Funcionário ou Terceirizado

1) Conheço o Programa USP Recicla.

Sim;

Não, se "não" PARE AQUI!

2) O USP Recicla oferece cursos de aprendizado à comunidade do Campus.

\begin{tabular}{|l|l|l|l|l|l|l|l|l|l|l|l|l|}
\hline \multirow{2}{*}{ Nunca } & 0 & 1 & 2 & 3 & 4 & 5 & 6 & 7 & 8 & 9 & 10 & \multirow{2}{*}{ Sempre } \\
\cline { 2 - 10 } & & & & & & & & & & & & \\
\hline
\end{tabular}

3) Participo de palestras e eventos oferecidos pelo USP Recicla.

\begin{tabular}{|l|l|l|l|l|l|l|l|l|l|l|l|l|}
\hline \multirow{2}{*}{ Nunca } & 0 & 1 & 2 & 3 & 4 & 5 & 6 & 7 & 8 & 9 & 10 & \multirow{2}{*}{ Sempre } \\
\cline { 2 - 9 } & & & & & & & & & & & & \\
\hline
\end{tabular}

4) Tenho acesso às informações sobre o USP Recicla.

Não;

Sim, se "sim", pelo(s) seguinte(s) meio(s):

( ) Internet ( ) Telefone ( ) Folhetos, Cartazes ( ) Palestras

5) Contribuo com a coleta seletiva do USP Recicla separando os materiais na Universidade.

\begin{tabular}{|l|l|l|l|l|l|l|l|l|l|l|l|l|}
\hline \multirow{2}{*}{ Nunca } & 0 & 1 & 2 & 3 & 4 & 5 & 6 & 7 & 8 & 9 & 10 & \multirow{2}{*}{ Sempre } \\
\cline { 2 - 9 } & & & & & & & & & & & & \\
\hline
\end{tabular}


6) Aplico o conhecimento aprendido com o USP Recicla fora da Universidade.

\begin{tabular}{|l|l|l|l|l|l|l|l|l|l|l|l|l|}
\multirow{2}{*}{ Nunca } & 0 & 1 & 2 & 3 & 4 & 5 & 6 & 7 & 8 & 9 & 10 & \multirow{2}{*}{ Sempre } \\
\cline { 2 - 11 } & & & & & & & & & & & & \\
\hline
\end{tabular}

7) Participo com sugestões/críticas para a melhoria do USP Recicla.

\begin{tabular}{|l|l|l|l|l|l|l|l|l|l|l|l|l|}
\hline \multirow{2}{*}{ Nunca } & 0 & 1 & 2 & 3 & 4 & 5 & 6 & 7 & 8 & 9 & 10 & \multirow{2}{*}{ Sempre } \\
\cline { 2 - 10 } & & & & & & & & & & & & \\
\hline
\end{tabular}

Se respondeu NUNCA (0), vá para a questão 9.

8) Minhas sugestões/críticas são ouvidas pelos responsáveis pelo USP Recicla.

\begin{tabular}{|l|l|l|l|l|l|l|l|l|l|l|l|l|}
\hline \multirow{2}{*}{ Nunca } & 0 & 1 & 2 & 3 & 4 & 5 & 6 & 7 & 8 & 9 & 10 & \multirow{2}{*}{ Sempre } \\
\cline { 2 - 11 } & & & & & & & & & & & & \\
\hline
\end{tabular}

9) As informações fornecidas pelo USP Recicla são:

\begin{tabular}{|l|l|l|l|l|l|l|l|l|l|l|l|l|}
\hline \multirow{2}{*}{ Confusas } & 0 & 1 & 2 & 3 & 4 & 5 & 6 & 7 & 8 & 9 & 10 & \multirow{2}{*}{ Claras } \\
\cline { 2 - 11 } & & & & & & & & & & & & \\
\hline
\end{tabular}

10) Em relação às iniciativas tomadas pelo USP Recicla:

\begin{tabular}{|l|l|l|l|l|l|l|l|l|l|l|l|l|}
\hline \multirow{2}{*}{ Discordo } & 0 & 1 & 2 & 3 & 4 & 5 & 6 & 7 & 8 & 9 & 10 & \multirow{2}{*}{ Concordo } \\
\cline { 2 - 10 } & & & & & & & & & & & & \\
\hline
\end{tabular}

11) O USP Recicla influencia de alguma forma minha relação com as questões ambientais.

\begin{tabular}{|l|l|l|l|l|l|l|l|l|l|l|l|l|}
\hline \multirow{2}{*}{ Nunca } & 0 & 1 & 2 & 3 & 4 & 5 & 6 & 7 & 8 & 9 & 10 & \multirow{2}{*}{ Sempre } \\
\cline { 2 - 10 } & & & & & & & & & & & & \\
\hline
\end{tabular}

Avalie somente o questionário

\begin{tabular}{|c|c|c|c|c|c|c|c|c|c|c|c|}
\hline \multirow{2}{*}{ Nota } & 0 & 1 & 2 & 3 & 4 & 5 & 6 & 7 & 8 & 9 & 10 \\
\cline { 2 - 13 } & & & & & & & & & & & \\
\hline
\end{tabular}

Caso tenha observações, críticas e sugestões, por favor, descreva abaixo. 
QUESTIONÁRIO (UFSCar)

DATA:

$/ 05 / 2007$

Prezado(a) Senhor(a), este questionário foi elaborado com a finalidade de levantar dados a respeito do Programa de Reciclagem da UFSCar, no período de 14 a 18 de maio de 2007. Este instrumento faz parte de duas pesquisas de mestrado da Escola de Engenharia de São Carlos, do Departamento de Transportes, na área de Planejamento e Operação de Sistemas de Transportes.

Respondendo ao questionário você estará colaborando para a melhoria do Programa de Reciclagem dessa Universidade, então, por favor, responda de maneira mais fiel possível à sua impressão em relação ao programa abordado.

$\begin{array}{cc}\text { Gênero } & \text { Cargo } \\ \square \quad \text { Feminino } & \square \text { Aluno Graduação } \\ \square \text { Masculino } & \square \text { Aluno Pós-Graduação } \\ & \square \text { Docente } \\ & \square \text { Funcionário ou Terceirizado }\end{array}$

1) Conheço o Programa de Reciclagem da UFSCar.

Sim;

Não, se "não" PARE AQUI!

2) O Programa de Reciclagem da UFSCar oferece cursos de aprendizado à comunidade do Campus.

\begin{tabular}{|l|l|l|l|l|l|l|l|l|l|l|l|l|}
\hline \multirow{2}{*}{ Nunca } & 0 & 1 & 2 & 3 & 4 & 5 & 6 & 7 & 8 & 9 & 10 & \multirow{2}{*}{ Sempre } \\
\cline { 2 - 7 } & & & & & & & & & & & & \\
\hline
\end{tabular}

3) Participo de palestras e eventos oferecidos pelo Programa de Reciclagem da UFSCar.

\begin{tabular}{|l|l|l|l|l|l|l|l|l|l|l|l|l|}
\hline \multirow{2}{*}{ Nunca } & 0 & 1 & 2 & 3 & 4 & 5 & 6 & 7 & 8 & 9 & 10 & \multirow{2}{*}{ Sempre } \\
\cline { 2 - 10 } & & & & & & & & & & & & \\
\hline
\end{tabular}

4) Tenho acesso às informações sobre o Programa de Reciclagem da UFSCar.
Não;
Sim, se "sim", pelo(s) seguinte(s) meio(s):
( ) Internet ( ) Telefone ( ) Folhetos, Cartazes ( ) Palestras

5) Contribuo com a coleta seletiva do Programa de Reciclagem da UFSCar separando os materiais na Universidade.

\begin{tabular}{|l|l|l|l|l|l|l|l|l|l|l|l|l|}
\hline \multirow{2}{*}{ Nunca } & 0 & 1 & 2 & 3 & 4 & 5 & 6 & 7 & 8 & 9 & 10 & \multirow{2}{*}{ Sempre } \\
\cline { 2 - 9 } & & & & & & & & & & & & \\
\hline
\end{tabular}

6) Aplico o conhecimento aprendido com o Programa de Reciclagem da UFSCar fora da Universidade.

\begin{tabular}{|l|l|l|l|l|l|l|l|l|l|l|l|l|}
\hline \multirow{2}{*}{ Nunca } & 0 & 1 & 2 & 3 & 4 & 5 & 6 & 7 & 8 & 9 & 10 & \multirow{2}{*}{ Sempre } \\
\hline & & & & & & & & & & & & \\
\hline
\end{tabular}


7) Participo com sugestões/críticas para a melhoria do Programa de Reciclagem da UFSCar.

\begin{tabular}{|l|l|l|l|l|l|l|l|l|l|l|l|l|}
\hline \multirow{2}{*}{ Nunca } & 0 & 1 & 2 & 3 & 4 & 5 & 6 & 7 & 8 & 9 & 10 & \multirow{2}{*}{ Sempre } \\
\cline { 2 - 10 } & & & & & & & & & & & & \\
\hline
\end{tabular}

Se respondeu NUNCA (0), vá para a questão 9.

8) Minhas sugestões/críticas são ouvidas pelos responsáveis pelo Programa de Reciclagem da UFSCar.

\begin{tabular}{|l|l|l|l|l|l|l|l|l|l|l|l|l|}
\hline \multirow{2}{*}{ Nunca } & 0 & 1 & 2 & 3 & 4 & 5 & 6 & 7 & 8 & 9 & 10 & \multirow{2}{*}{ Sempre } \\
\cline { 2 - 9 } & & & & & & & & & & & & \\
\hline
\end{tabular}

9) As informações fornecidas pelo Programa de Reciclagem da UFSCar são:

\begin{tabular}{|l|l|l|l|l|l|l|l|l|l|l|l|l|}
\hline \multirow{2}{*}{ Confusas } & 0 & 1 & 2 & 3 & 4 & 5 & 6 & 7 & 8 & 9 & 10 & \multirow{2}{*}{ Claras } \\
\cline { 2 - 9 } & & & & & & & & & & & & \\
\hline
\end{tabular}

10) Em relação às iniciativas tomadas pelo Programa de Reciclagem da UFSCar:

\begin{tabular}{|c|c|c|c|c|c|c|c|c|c|c|c|c|}
\hline & 0 & 1 & 2 & 3 & 4 & 5 & 6 & 7 & 8 & 9 & 10 & ord \\
\hline
\end{tabular}

11) O Programa de Reciclagem da UFSCar influencia de alguma forma minha relação com as questões ambientais.

\begin{tabular}{|l|l|l|l|l|l|l|l|l|l|l|l|l|}
\hline \multirow{2}{*}{ Nunca } & 0 & 1 & 2 & 3 & 4 & 5 & 6 & 7 & 8 & 9 & 10 & \multirow{2}{*}{ Sempre } \\
\cline { 2 - 10 } & & & & & & & & & & & & \\
\hline
\end{tabular}

Avalie somente o questionário

\begin{tabular}{|l|c|c|c|c|c|c|c|c|c|c|c|}
\hline \multirow{2}{*}{ Nota } & 0 & 1 & 2 & 3 & 4 & 5 & 6 & 7 & 8 & 9 & 10 \\
\hline & & & & & & & & & & & \\
\hline
\end{tabular}

Caso tenha observações, críticas e sugestões, por favor, descreva abaixo. 
QUESTIONÁRIO - FUNCIONÁRIOS (USP-SÃO CARLOS) DATA:

$/ 05 / 2007$

Prezado(a) Senhor(a), este questionário foi elaborado com a finalidade de levantar dados a respeito do Programa de Reciclagem USP Recicla, da USP - São Carlos, no mês de maio de 2007. Este instrumento faz parte de duas pesquisas de mestrado da Escola de Engenharia de São Carlos, do Departamento de Transportes, na área de Planejamento e Operação de Sistemas de Transportes.

Respondendo ao questionário você estará colaborando para a melhoria do programa USP Recicla dessa Universidade, então, por favor, responda de maneira mais fiel possível à sua impressão em relação ao programa abordado.

Instrução: Marque com um "X" a resposta que mais lhe convém.

Gênero

( ) Feminino

( ) Masculino

\section{Cargo}

( ) Aluno Graduação

( ) Aluno Pós-Graduação

( ) Docente

( ) Funcionário ou Terceirizado

1) Conheço o Programa USP Recicla.

( ) Sim;

( ) Não, se "não" PARE AQUI!

2) Recebo cursos de aprendizado por parte do USP Recicla.

\begin{tabular}{|l|l|l|l|l|l|l|l|l|l|l|l|l|}
\hline \multirow{2}{*}{ Nunca } & 0 & 1 & 2 & 3 & 4 & 5 & 6 & 7 & 8 & 9 & 10 & \multirow{2}{*}{ Sempre } \\
\cline { 2 - 10 } & & & & & & & & & & & & \\
\hline
\end{tabular}

3) Tenho acesso às informações sobre o USP Recicla.

( ) Não;

( ) Sim, se "sim", pelo(s) seguinte(s) meio(s):
( ) Internet
( ) Telefone
( ) Folhetos, Cartazes
( ) Palestras

4) Contribuo com a coleta seletiva do USP Recicla separando os materiais na Universidade.

\begin{tabular}{|l|l|l|l|l|l|l|l|l|l|l|l|l|}
\hline \multirow{2}{*}{ Nunca } & 0 & 1 & 2 & 3 & 4 & 5 & 6 & 7 & 8 & 9 & 10 & \multirow{2}{*}{ Sempre } \\
\cline { 2 - 10 } & & & & & & & & & & & & \\
\hline
\end{tabular}

5) Aplico o conhecimento aprendido com o USP Recicla fora da Universidade.

\begin{tabular}{|l|l|l|l|l|l|l|l|l|l|l|l|l|}
\hline \multirow{2}{*}{ Nunca } & 0 & 1 & 2 & 3 & 4 & 5 & 6 & 7 & 8 & 9 & 10 & \multirow{2}{*}{ Sempre } \\
\cline { 2 - 12 } & & & & & & & & & & & & \\
\hline
\end{tabular}

6) Participo com sugestões/críticas para a melhoria do USP Recicla.

\begin{tabular}{|l|l|l|l|l|l|l|l|l|l|l|l|l|}
\hline \multirow{2}{*}{ Nunca } & 0 & 1 & 2 & 3 & 4 & 5 & 6 & 7 & 8 & 9 & 10 & \multirow{2}{*}{ Sempre } \\
\cline { 2 - 11 } & & & & & & & & & & & & \\
\hline
\end{tabular}

Se respondeu NUNCA (0), vá para a questão 8. 
7) Minhas sugestões/críticas são ouvidas pelos responsáveis pelo USP Recicla.

\begin{tabular}{|l|l|l|l|l|l|l|l|l|l|l|l|l|}
\hline \multirow{2}{*}{ Nunca } & 0 & 1 & 2 & 3 & 4 & 5 & 6 & 7 & 8 & 9 & 10 & \multirow{2}{*}{ Sempre } \\
\cline { 2 - 10 } & & & & & & & & & & & & \\
\hline
\end{tabular}

8) Estou satisfeito com minha função no USP Recicla.
( ) $\operatorname{Sim}$
( ) Não

9) As informações fornecidas pelo USP Recicla são:

\begin{tabular}{|l|l|l|l|l|l|l|l|l|l|l|l|l|}
\hline \multirow{2}{*}{ Confusas } & 0 & 1 & 2 & 3 & 4 & 5 & 6 & 7 & 8 & 9 & 10 & \multirow{2}{*}{ Claras } \\
\cline { 2 - 8 } & & & & & & & & & & & & \\
\hline
\end{tabular}

10) Em relação às iniciativas tomadas pelo USP Recicla:

\begin{tabular}{|l|l|l|l|l|l|l|l|l|l|l|l|l|}
\multirow{2}{*}{ Discordo } & 0 & 1 & 2 & 3 & 4 & 5 & 6 & 7 & 8 & 9 & 10 & \multirow{2}{*}{ Concordo } \\
\cline { 2 - 10 } & & & & & & & & & & & & \\
\hline
\end{tabular}

11) Participo de palestras e eventos oferecidos pelo USP Recicla.

\begin{tabular}{|l|l|l|l|l|l|l|l|l|l|l|l|l|}
\hline \multirow{2}{*}{ Nunca } & 0 & 1 & 2 & 3 & 4 & 5 & 6 & 7 & 8 & 9 & 10 & \multirow{2}{*}{ Sempre } \\
\cline { 2 - 8 } & & & & & & & & & & & & \\
\hline
\end{tabular}

12) O USP Recicla influencia de alguma forma minha relação com as questões ambientais.

\begin{tabular}{|l|l|l|l|l|l|l|l|l|l|l|l|l|}
\hline \multirow{2}{*}{ Nunca } & 0 & 1 & 2 & 3 & 4 & 5 & 6 & 7 & 8 & 9 & 10 & \multirow{2}{*}{ Sempre } \\
\cline { 2 - 11 } & & & & & & & & & & & & \\
\hline
\end{tabular}

Avalie somente o questionário

\begin{tabular}{|l|l|l|l|l|l|l|l|l|l|l|l|}
\hline \multirow{2}{*}{ Nota } & 0 & 1 & 2 & 3 & 4 & 5 & 6 & 7 & 8 & 9 & 10 \\
\cline { 2 - 12 } & & & & & & & & & & & \\
\hline
\end{tabular}

Caso tenha observações, críticas e sugestões, por favor, descreva abaixo. 
Prezado(a) Senhor(a), este questionário foi elaborado com a finalidade de levantar dados a respeito do Programa de Reciclagem USP Recicla, da USP - São Carlos, no mês de maio de 2007. Este instrumento faz parte de duas pesquisas de mestrado da Escola de Engenharia de São Carlos, do Departamento de Transportes, na área de Planejamento e Operação de Sistemas de Transportes.

Respondendo ao questionário você estará colaborando para a melhoria do programa USP Recicla dessa Universidade, então, por favor, responda de maneira mais fiel possível à sua impressão em relação ao programa abordado.

Instrução: Marque com um " $\mathbf{X}$ " a resposta que mais lhe convém.

Gênero

( ) Feminino

( ) Masculino

\section{Cargo}

( ) Aluno Graduação

( ) Aluno Pós-Graduação

( ) Docente

( ) Funcionário ou Terceirizado

1) Observo melhorias nos processos internos do USP Recicla.

\begin{tabular}{|l|l|l|l|l|l|l|l|l|l|l|l|l|}
\hline \multirow{2}{*}{ Nunca } & 0 & 1 & 2 & 3 & 4 & 5 & 6 & 7 & 8 & 9 & 10 & \multirow{2}{*}{ Sempre } \\
\cline { 2 - 11 } & & & & & & & & & & & & \\
\hline
\end{tabular}

2) O USP Recicla oferece cursos de aprendizado à comunidade do Campus.

\begin{tabular}{|l|l|l|l|l|l|l|l|l|l|l|l|l|}
\hline \multirow{2}{*}{ Nunca } & 0 & 1 & 2 & 3 & 4 & 5 & 6 & 7 & 8 & 9 & 10 & \multirow{2}{*}{ Sempre } \\
\cline { 2 - 11 } & & & & & & & & & & & & \\
\hline
\end{tabular}

3) Para mim, o acervo de informações do USP Recicla é de acesso:

\begin{tabular}{|l|l|l|l|l|l|l|l|l|l|l|l|l|}
\hline \multirow{2}{*}{ Difícil } & 0 & 1 & 2 & 3 & 4 & 5 & 6 & 7 & 8 & 9 & 10 & \multirow{2}{*}{ Fácil } \\
\hline & & & & & & & & & & & & \\
\hline
\end{tabular}

4) O conhecimento gerado no USP Recicla é armazenado de alguma forma.

\begin{tabular}{|l|l|l|l|l|l|l|l|l|l|l|l|l|}
\multirow{2}{*}{ Discordo } & 0 & 1 & 2 & 3 & 4 & 5 & 6 & 7 & 8 & 9 & 10 & \multirow{2}{*}{ Concordo } \\
\cline { 2 - 12 } & & & & & & & & & & & & \\
\hline
\end{tabular}

5) O conhecimento gerado é difundido aos envolvidos no USP Recicla.

\begin{tabular}{|l|l|l|l|l|l|l|l|l|l|l|l|l|}
\hline \multirow{2}{*}{ Discordo } & 0 & 1 & 2 & 3 & 4 & 5 & 6 & 7 & 8 & 9 & 10 & \multirow{2}{*}{ Concordo } \\
\cline { 2 - 11 } & & & & & & & & & & & & \\
\hline
\end{tabular}

6) O conhecimento gerado pelo USP Recicla é aplicado neste.

\begin{tabular}{|l|l|l|l|l|l|l|l|l|l|l|l|l|}
\hline \multirow{2}{*}{ Discordo } & 0 & 1 & 2 & 3 & 4 & 5 & 6 & 7 & 8 & 9 & 10 & \multirow{2}{*}{ Concordo } \\
\cline { 2 - 12 } & & & & & & & & & & & & \\
\hline
\end{tabular}

7) Contribuo com a coleta seletiva do USP Recicla separando os materiais na Universidade.

\begin{tabular}{|l|l|l|l|l|l|l|l|l|l|l|l|l|}
\hline \multirow{2}{*}{ Nunca } & 0 & 1 & 2 & 3 & 4 & 5 & 6 & 7 & 8 & 9 & 10 & \multirow{2}{*}{ Sempre } \\
\hline & & & & & & & & & & & & \\
\hline
\end{tabular}


8) Aplico o conhecimento aprendido com o USP Recicla fora da Universidade.

\begin{tabular}{|l|l|l|l|l|l|l|l|l|l|l|l|l|}
\hline \multirow{2}{*}{ Nunca } & 0 & 1 & 2 & 3 & 4 & 5 & 6 & 7 & 8 & 9 & 10 & \multirow{2}{*}{ Sempre } \\
\cline { 2 - 10 } & & & & & & & & & & & & \\
\hline
\end{tabular}

9) Participo com sugestões/críticas para a melhoria do USP Recicla.

\begin{tabular}{|l|l|l|l|l|l|l|l|l|l|l|l|l|}
\hline \multirow{2}{*}{ Nunca } & 0 & 1 & 2 & 3 & 4 & 5 & 6 & 7 & 8 & 9 & 10 & \multirow{2}{*}{ Sempre } \\
\cline { 2 - 10 } & & & & & & & & & & & & \\
\hline
\end{tabular}

Se respondeu NUNCA (0), vá para a questão 11.

10) Minhas sugestões/críticas são ouvidas pelos superiores dentro do USP Recicla.

\begin{tabular}{|l|l|l|l|l|l|l|l|l|l|l|l|l|}
\hline \multirow{2}{*}{ Nunca } & 0 & 1 & 2 & 3 & 4 & 5 & 6 & 7 & 8 & 9 & 10 & \multirow{2}{*}{ Sempre } \\
\cline { 2 - 11 } & & & & & & & & & & & & \\
\hline
\end{tabular}

11) Fico a vontade em fazer sugestões/críticas sobre o USP Recicla.

\begin{tabular}{|l|l|l|l|l|l|l|l|l|l|l|l|l|}
\hline \multirow{2}{*}{ Nunca } & 0 & 1 & 2 & 3 & 4 & 5 & 6 & 7 & 8 & 9 & 10 & \multirow{2}{*}{ Sempre } \\
\cline { 2 - 11 } & & & & & & & & & & & & \\
\hline
\end{tabular}

12) Estou satisfeito com minha função no USP Recicla.
( ) $\mathrm{Sim}$
( ) Não

13) Ocorre mudança de gestão do USP Recicla.

\begin{tabular}{|l|l|l|l|l|l|l|l|l|l|l|l|l|}
\hline \multirow{2}{*}{ Nunca } & 0 & 1 & 2 & 3 & 4 & 5 & 6 & 7 & 8 & 9 & 10 & \multirow{2}{*}{ Sempre } \\
\cline { 2 - 12 } & & & & & & & & & & & & \\
\hline
\end{tabular}

14) Em relação às iniciativas tomadas pelo USP Recicla:

\begin{tabular}{|l|c|c|c|c|c|c|c|c|c|c|c|c|}
\multirow{2}{*}{ Discordo } & 0 & 1 & 2 & 3 & 4 & 5 & 6 & 7 & 8 & 9 & 10 & \multirow{2}{*}{ Concordo } \\
\cline { 2 - 13 } & & & & & & & & & & & & \\
\hline
\end{tabular}

15) Participo de palestras e eventos oferecidos pelo USP Recicla.

\begin{tabular}{|l|l|l|l|l|l|l|l|l|l|l|l|l|}
\hline \multirow{2}{*}{ Nunca } & 0 & 1 & 2 & 3 & 4 & 5 & 6 & 7 & 8 & 9 & 10 & \multirow{2}{*}{ Sempre } \\
\cline { 2 - 10 } & & & & & & & & & & & & \\
\hline
\end{tabular}

16) O USP Recicla influencia de alguma forma minha relação com as questões ambientais.

\begin{tabular}{|l|l|l|l|l|l|l|l|l|l|l|l|l|}
\hline \multirow{2}{*}{ Nunca } & 0 & 1 & 2 & 3 & 4 & 5 & 6 & 7 & 8 & 9 & 10 & \multirow{2}{*}{ Sempre } \\
\cline { 2 - 9 } & & & & & & & & & & & & \\
\hline
\end{tabular}

Avalie somente o questionário

\begin{tabular}{|l|l|l|l|l|l|l|l|l|l|l|l|}
\hline \multirow{2}{*}{ Nota } & 0 & 1 & 2 & 3 & 4 & 5 & 6 & 7 & 8 & 9 & 10 \\
\hline & & & & & & & & & & & \\
\hline
\end{tabular}

Caso tenha observações, críticas e sugestões, por favor, descreva abaixo. 
Prezado(a) Senhor(a), este questionário foi elaborado com a finalidade de levantar dados a respeito do Programa de Reciclagem da UFSCar, no mês de maio de 2007. Este instrumento faz parte de duas pesquisas de mestrado da Escola de Engenharia de São Carlos, do Departamento de Transportes, na área de Planejamento e Operação de Sistemas de Transportes.

Respondendo ao questionário você estará colaborando para a melhoria do Programa de Reciclagem dessa Universidade, então, por favor, responda de maneira mais fiel possível à sua impressão em relação ao programa abordado.

Instrução: Marque com um " $\mathbf{X}$ " a resposta que mais lhe convém.
Gênero
Cargo
( ) Feminino
( ) Aluno Graduação
( ) Masculino
( ) Aluno Pós-Graduação
( ) Docente
( ) Funcionário ou Terceirizado

1) Observo melhorias nos processos internos do Programa de Reciclagem da UFSCar.

\begin{tabular}{|l|l|l|l|l|l|l|l|l|l|l|l|l|}
\hline \multirow{2}{*}{ Nunca } & 0 & 1 & 2 & 3 & 4 & 5 & 6 & 7 & 8 & 9 & 10 & \multirow{2}{*}{ Sempre } \\
\cline { 2 - 9 } & & & & & & & & & & & & \\
\hline
\end{tabular}

2) O Programa de Reciclagem da UFSCar oferece cursos de aprendizado à comunidade do Campus.

\begin{tabular}{|l|l|l|l|l|l|l|l|l|l|l|l|l|}
\hline \multirow{2}{*}{ Nunca } & 0 & 1 & 2 & 3 & 4 & 5 & 6 & 7 & 8 & 9 & 10 & \multirow{2}{*}{ Sempre } \\
\cline { 2 - 8 } & & & & & & & & & & & & \\
\hline
\end{tabular}

3) Para mim, o acervo de informações do Programa de Reciclagem da UFSCar é de acesso:

\begin{tabular}{|l|l|l|l|l|l|l|l|l|l|l|l|l|}
\hline \multirow{2}{*}{ Difícil } & 0 & 1 & 2 & 3 & 4 & 5 & 6 & 7 & 8 & 9 & 10 & \multirow{2}{*}{ Fácil } \\
\cline { 2 - 8 } & & & & & & & & & & & & \\
\hline
\end{tabular}

4) O conhecimento gerado no Programa de Reciclagem da UFSCar é armazenado de alguma forma.

\begin{tabular}{|l|l|l|l|l|l|l|l|l|l|l|l|l|}
\hline \multirow{2}{*}{ Discordo } & 0 & 1 & 2 & 3 & 4 & 5 & 6 & 7 & 8 & 9 & 10 & \multirow{2}{*}{ Concordo } \\
\cline { 2 - 10 } & & & & & & & & & & & & \\
\hline
\end{tabular}

5) O conhecimento gerado é difundido aos envolvidos no Programa de Reciclagem da UFSCar.

\begin{tabular}{|l|l|l|l|l|l|l|l|l|l|l|l|l|}
\hline \multirow{2}{*}{ Discordo } & 0 & 1 & 2 & 3 & 4 & 5 & 6 & 7 & 8 & 9 & 10 & \multirow{2}{*}{ Concordo } \\
\cline { 2 - 9 } & & & & & & & & & & & & \\
\hline
\end{tabular}

6) O conhecimento gerado pelo Programa de Reciclagem da UFSCar é aplicado neste.

\begin{tabular}{|l|l|l|l|l|l|l|l|l|l|l|l|l|}
\hline \multirow{2}{*}{ Discordo } & 0 & 1 & 2 & 3 & 4 & 5 & 6 & 7 & 8 & 9 & 10 & \multirow{2}{*}{ Concordo } \\
\cline { 2 - 10 } & & & & & & & & & & & & \\
\hline
\end{tabular}

7) Contribuo com a coleta seletiva do Programa de Reciclagem da UFSCar separando os materiais na Universidade.

\begin{tabular}{|l|l|l|l|l|l|l|l|l|l|l|l|l|}
\hline \multirow{2}{*}{ Nunca } & 0 & 1 & 2 & 3 & 4 & 5 & 6 & 7 & 8 & 9 & 10 & \multirow{2}{*}{ Sempre } \\
\cline { 2 - 10 } & & & & & & & & & & & & \\
\hline
\end{tabular}


8) Aplico o conhecimento aprendido com o Programa de Reciclagem da UFSCar fora da Universidade.

\begin{tabular}{|l|l|l|l|l|l|l|l|l|l|l|l|l|}
\hline \multirow{2}{*}{ Nunca } & 0 & 1 & 2 & 3 & 4 & 5 & 6 & 7 & 8 & 9 & 10 & \multirow{2}{*}{ Sempre } \\
\cline { 2 - 11 } & & & & & & & & & & & & \\
\hline
\end{tabular}

9) Participo com sugestões/críticas para a melhoria do Programa de Reciclagem da UFSCar.

\begin{tabular}{|l|l|l|l|l|l|l|l|l|l|l|l|l|}
\hline \multirow{2}{*}{ Nunca } & 0 & 1 & 2 & 3 & 4 & 5 & 6 & 7 & 8 & 9 & 10 & \multirow{2}{*}{ Sempre } \\
\cline { 2 - 10 } & & & & & & & & & & & & \\
\hline
\end{tabular}

Se respondeu NUNCA (0), vá para a questão 11.

10) Minhas sugestões/críticas são ouvidas pelos superiores dentro do Programa de Reciclagem da UFSCar.

\begin{tabular}{|l|l|l|l|l|l|l|l|l|l|l|l|l|}
\hline \multirow{2}{*}{ Nunca } & 0 & 1 & 2 & 3 & 4 & 5 & 6 & 7 & 8 & 9 & 10 & \multirow{2}{*}{ Sempre } \\
\cline { 2 - 11 } & & & & & & & & & & & & \\
\hline
\end{tabular}

11) Fico a vontade em fazer sugestões/críticas sobre o Programa de Reciclagem da UFSCar.

\begin{tabular}{|l|l|l|l|l|l|l|l|l|l|l|l|l|}
\hline \multirow{2}{*}{ Nunca } & 0 & 1 & 2 & 3 & 4 & 5 & 6 & 7 & 8 & 9 & 10 & \multirow{2}{*}{ Sempre } \\
\cline { 2 - 10 } & & & & & & & & & & & & \\
\hline
\end{tabular}

12) Estou satisfeito com minha função no Programa de Reciclagem da UFSCar.

( ) $\mathrm{Sim}$

( ) Não

13) Ocorre mudança de gestão do Programa de Reciclagem da UFSCar.

\begin{tabular}{|l|l|l|l|l|l|l|l|l|l|l|l|l|}
\hline \multirow{2}{*}{ Nunca } & 0 & 1 & 2 & 3 & 4 & 5 & 6 & 7 & 8 & 9 & 10 & \multirow{2}{*}{ Sempre } \\
\cline { 2 - 9 } & & & & & & & & & & & & \\
\hline
\end{tabular}

14) Em relação às iniciativas tomadas pelo Programa de Reciclagem da UFSCar:

\begin{tabular}{|l|l|l|l|l|l|l|l|l|l|l|l|l|}
\hline \multirow{2}{*}{ Discordo } & 0 & 1 & 2 & 3 & 4 & 5 & 6 & 7 & 8 & 9 & 10 & \multirow{2}{*}{ Concordo } \\
\cline { 2 - 10 } & & & & & & & & & & & & \\
\hline
\end{tabular}

15) Participo de palestras e eventos oferecidos pelo Programa de Reciclagem da UFSCar.

\begin{tabular}{|l|l|l|l|l|l|l|l|l|l|l|l|l|}
\hline \multirow{2}{*}{ Nunca } & 0 & 1 & 2 & 3 & 4 & 5 & 6 & 7 & 8 & 9 & 10 & \multirow{2}{*}{ Sempre } \\
\cline { 2 - 11 } & & & & & & & & & & & & \\
\hline
\end{tabular}

16) O Programa de Reciclagem da UFSCar influencia de alguma forma minha relação com as questões ambientais.

\begin{tabular}{|l|l|l|l|l|l|l|l|l|l|l|l|l|}
\hline \multirow{2}{*}{ Nunca } & 0 & 1 & 2 & 3 & 4 & 5 & 6 & 7 & 8 & 9 & 10 & \multirow{2}{*}{ Sempre } \\
\cline { 2 - 9 } & & & & & & & & & & & & \\
\hline
\end{tabular}

Avalie somente o questionário

\begin{tabular}{|l|l|l|l|l|l|l|l|l|l|l|l|}
\hline \multirow{2}{*}{ Nota } & 0 & 1 & 2 & 3 & 4 & 5 & 6 & 7 & 8 & 9 & 10 \\
\cline { 2 - 12 } & & & & & & & & & & & \\
\hline
\end{tabular}

Caso tenha observações, críticas e sugestões, por favor, descreva abaixo. 


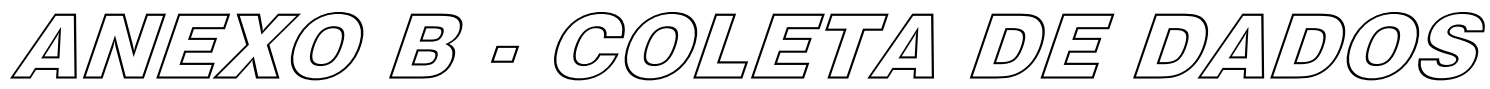

\section{QUESTIONÁRIO DOS GESTORES DOS}

\section{PROGRAMAS DA USP E DA UFSCar}

Tabela B.01: Dados pessoais dos gestores dos Programas da USP e da UFSCar.

\begin{tabular}{ccc|cc}
\hline Gênero & USP & \% USP & UFSCar & \% UFSCar \\
\hline Feminino & 19 & 45 & 6 & 46 \\
Masculino & 23 & 55 & 7 & 54 \\
\hline TOTAL & 42 & 100 & 13 & 100 \\
\hline
\end{tabular}

Tabela B.02: Dados pessoais dos gestores dos Programas da USP e da UFSCar.

\begin{tabular}{ccc|cc}
\hline Cargo & USP & \% USP & UFSCar & \% UFSCar \\
\hline Aluno Graduação & 0 & 0 & 0 & 0 \\
$\begin{array}{c}\text { Aluno Pós- } \\
\text { Graduação }\end{array}$ & 1 & 2 & 1 & 8 \\
Docente & 24 & 57 & 8 & 62 \\
$\begin{array}{c}\text { Funcionário ou } \\
\text { Terceirizado }\end{array}$ & 17 & 40 & 4 & 31 \\
\hline TOTAL & 42 & 100 & 13 & 100 \\
\hline
\end{tabular}

Tabela B.03: Dados referentes à questão 01 do questionário dos gestores dos Programas da USP e da UFSCar.

\begin{tabular}{cccccccccccc|c}
\hline Nota & $\mathbf{0}$ & $\mathbf{1}$ & $\mathbf{2}$ & $\mathbf{3}$ & $\mathbf{4}$ & $\mathbf{5}$ & $\mathbf{6}$ & $\mathbf{7}$ & $\mathbf{8}$ & $\mathbf{9}$ & $\mathbf{1 0}$ & TOTAL \\
\hline USP & 1 & 0 & 0 & 2 & 4 & 6 & 2 & 9 & 10 & 2 & 6 & 42 \\
\% USP & 2 & 0 & 0 & 5 & 10 & 14 & 5 & 21 & 24 & 5 & 14 & 100 \\
\hline UFSCar & 0 & 0 & 0 & 2 & 0 & 2 & 1 & 1 & 6 & 1 & 0 & 13 \\
\% UFSCar & 0 & 0 & 0 & 15 & 0 & 15 & 8 & 8 & 46 & 8 & 0 & 100 \\
\hline
\end{tabular}


Tabela B.04: Dados referentes à questão 02 do questionário dos gestores dos Programas da USP e da UFSCar.

\begin{tabular}{cccccccccccc|c}
\hline Nota & $\mathbf{0}$ & $\mathbf{1}$ & $\mathbf{2}$ & $\mathbf{3}$ & $\mathbf{4}$ & $\mathbf{5}$ & $\mathbf{6}$ & $\mathbf{7}$ & $\mathbf{8}$ & $\mathbf{9}$ & $\mathbf{1 0}$ & TOTAL \\
\hline USP & 2 & 1 & 1 & 3 & 1 & 7 & 3 & 6 & 5 & 3 & 9 & 41 \\
\% USP & 5 & 2 & 2 & 7 & 2 & 17 & 7 & 15 & 12 & 7 & 22 & 100 \\
\hline UFSCar & 0 & 1 & 0 & 1 & 0 & 3 & 1 & 5 & 1 & 0 & 0 & 12 \\
\% UFSCar & 0 & 8 & 0 & 8 & 0 & 25 & 8 & 42 & 8 & 0 & 0 & 100 \\
\hline
\end{tabular}

Tabela B.05: Dados referentes à questão 03 do questionário dos gestores dos Programas da USP e da UFSCar.

\begin{tabular}{cccccccccccc|c}
\hline Nota & $\mathbf{0}$ & $\mathbf{1}$ & $\mathbf{2}$ & $\mathbf{3}$ & $\mathbf{4}$ & $\mathbf{5}$ & $\mathbf{6}$ & $\mathbf{7}$ & $\mathbf{8}$ & $\mathbf{9}$ & $\mathbf{1 0}$ & TOTAL \\
\hline USP & 2 & 2 & 1 & 2 & 0 & 4 & 5 & 5 & 5 & 5 & 11 & 42 \\
\% USP & 5 & 5 & 2 & 5 & 0 & 10 & 12 & 12 & 12 & 12 & 26 & 100 \\
\hline UFSCar & 0 & 0 & 1 & 1 & 1 & 5 & 0 & 1 & 1 & 0 & 2 & 12 \\
\% UFSCar & 0 & 0 & 8 & 8 & 8 & 42 & 0 & 8 & 8 & 0 & 17 & 100 \\
\hline
\end{tabular}

Tabela B.06: Dados referentes à questão 04 do questionário dos gestores dos Programas da USP e da UFSCar.

\begin{tabular}{cccccccccccc|c}
\hline Nota & $\mathbf{0}$ & $\mathbf{1}$ & $\mathbf{2}$ & $\mathbf{3}$ & $\mathbf{4}$ & $\mathbf{5}$ & $\mathbf{6}$ & $\mathbf{7}$ & $\mathbf{8}$ & $\mathbf{9}$ & $\mathbf{1 0}$ & TOTAL \\
\hline USP & 1 & 2 & 1 & 1 & 0 & 4 & 3 & 6 & 7 & 5 & 10 & 40 \\
\% USP & 3 & 5 & 3 & 3 & 0 & 10 & 8 & 15 & 18 & 13 & 25 & 100 \\
\hline UFSCar & 1 & 1 & 0 & 0 & 1 & 2 & 1 & 1 & 2 & 2 & 1 & 12 \\
\% UFSCar & 8 & 8 & 0 & 0 & 8 & 17 & 8 & 8 & 17 & 17 & 8 & 100 \\
\hline
\end{tabular}

Tabela B.07: Dados referentes à questão 05 do questionário dos gestores dos Programas da USP e da UFSCar.

\begin{tabular}{cccccccccccc|c}
\hline Nota & $\mathbf{0}$ & $\mathbf{1}$ & $\mathbf{2}$ & $\mathbf{3}$ & $\mathbf{4}$ & $\mathbf{5}$ & $\mathbf{6}$ & $\mathbf{7}$ & $\mathbf{8}$ & $\mathbf{9}$ & $\mathbf{1 0}$ & TOTAL \\
\hline USP & 0 & 0 & 2 & 2 & 2 & 4 & 7 & 5 & 5 & 3 & 11 & 41 \\
\% USP & 0 & 0 & 5 & 5 & 5 & 10 & 17 & 12 & 12 & 7 & 27 & 100 \\
\hline UFSCar & 0 & 1 & 2 & 0 & 0 & 2 & 3 & 2 & 0 & 2 & 0 & 12 \\
\% UFSCar & 0 & 8 & 17 & 0 & 0 & 17 & 25 & 17 & 0 & 17 & 0 & 100 \\
\hline
\end{tabular}


Tabela B.08: Dados referentes à questão 06 do questionário dos gestores dos Programas da USP e da UFSCar.

\begin{tabular}{cccccccccccc|c}
\hline Nota & $\mathbf{0}$ & $\mathbf{1}$ & $\mathbf{2}$ & $\mathbf{3}$ & $\mathbf{4}$ & $\mathbf{5}$ & $\mathbf{6}$ & $\mathbf{7}$ & $\mathbf{8}$ & $\mathbf{9}$ & $\mathbf{1 0}$ & TOTAL \\
\hline USP & 0 & 0 & 2 & 0 & 1 & 3 & 4 & 8 & 11 & 5 & 7 & 41 \\
\% USP & 0 & 0 & 5 & 0 & 2 & 7 & 10 & 20 & 27 & 12 & 17 & 100 \\
\hline UFSCar & 1 & 0 & 0 & 0 & 0 & 2 & 0 & 5 & 2 & 2 & 0 & 12 \\
\% UFSCar & 8 & 0 & 0 & 0 & 0 & 17 & 0 & 42 & 17 & 17 & 0 & 100 \\
\hline
\end{tabular}

Tabela B.09: Dados referentes à questão 07 do questionário dos gestores dos Programas da USP e da UFSCar.

\begin{tabular}{cccccccccccc|c}
\hline Nota & $\mathbf{0}$ & $\mathbf{1}$ & $\mathbf{2}$ & $\mathbf{3}$ & $\mathbf{4}$ & $\mathbf{5}$ & $\mathbf{6}$ & $\mathbf{7}$ & $\mathbf{8}$ & $\mathbf{9}$ & $\mathbf{1 0}$ & TOTAL \\
\hline USP & 0 & 1 & 1 & 0 & 0 & 1 & 1 & 2 & 4 & 4 & 28 & 42 \\
\% USP & 0 & 2 & 2 & 0 & 0 & 2 & 2 & 5 & 10 & 10 & 67 & 100 \\
\hline UFSCar & 0 & 0 & 0 & 0 & 0 & 0 & 0 & 0 & 0 & 4 & 9 & 13 \\
\% UFSCar & 0 & 0 & 0 & 0 & 0 & 0 & 0 & 0 & 0 & 31 & 69 & 100 \\
\hline
\end{tabular}

Tabela B.10: Dados referentes à questão 08 do questionário dos gestores dos Programas da USP e da UFSCar.

\begin{tabular}{cccccccccccc|c}
\hline Nota & $\mathbf{0}$ & $\mathbf{1}$ & $\mathbf{2}$ & $\mathbf{3}$ & $\mathbf{4}$ & $\mathbf{5}$ & $\mathbf{6}$ & $\mathbf{7}$ & $\mathbf{8}$ & $\mathbf{9}$ & $\mathbf{1 0}$ & TOTAL \\
\hline USP & 1 & 0 & 0 & 0 & 0 & 2 & 2 & 2 & 1 & 8 & 26 & 42 \\
\% USP & 2 & 0 & 0 & 0 & 0 & 5 & 5 & 5 & 2 & 19 & 62 & 100 \\
\hline UFSCar & 0 & 0 & 0 & 0 & 0 & 0 & 0 & 0 & 2 & 5 & 6 & 13 \\
\% UFSCar & 0 & 0 & 0 & 0 & 0 & 0 & 0 & 0 & 15 & 38 & 46 & 100 \\
\hline
\end{tabular}

Tabela B.11: Dados referentes à questão 09 do questionário dos gestores dos Programas da USP e da UFSCar.

\begin{tabular}{cccccccccccc|c}
\hline Nota & $\mathbf{0}$ & $\mathbf{1}$ & $\mathbf{2}$ & $\mathbf{3}$ & $\mathbf{4}$ & $\mathbf{5}$ & $\mathbf{6}$ & $\mathbf{7}$ & $\mathbf{8}$ & $\mathbf{9}$ & $\mathbf{1 0}$ & TOTAL \\
\hline USP & 2 & 0 & 0 & 2 & 0 & 5 & 1 & 6 & 4 & 3 & 19 & 42 \\
\% USP & 5 & 0 & 0 & 5 & 0 & 12 & 2 & 14 & 10 & 7 & 45 & 100 \\
\hline UFSCar & 2 & 0 & 0 & 0 & 0 & 2 & 1 & 0 & 4 & 2 & 2 & 13 \\
\% UFSCar & 15 & 0 & 0 & 0 & 0 & 15 & 8 & 0 & 31 & 15 & 15 & 100 \\
\hline
\end{tabular}


Tabela B.12: Dados referentes à questão 10 do questionário dos gestores dos Programas da USP e da UFSCar.

\begin{tabular}{cccccccccccc|c}
\hline Nota & $\mathbf{0}$ & $\mathbf{1}$ & $\mathbf{2}$ & $\mathbf{3}$ & $\mathbf{4}$ & $\mathbf{5}$ & $\mathbf{6}$ & $\mathbf{7}$ & $\mathbf{8}$ & $\mathbf{9}$ & $\mathbf{1 0}$ & TOTAL \\
\hline USP & 1 & 0 & 0 & 3 & 1 & 4 & 3 & 5 & 4 & 5 & 14 & 40 \\
\% USP & 3 & 0 & 0 & 8 & 3 & 10 & 8 & 13 & 10 & 13 & 35 & 100 \\
\hline UFSCar & 0 & 0 & 0 & 1 & 0 & 1 & 2 & 0 & 6 & 0 & 1 & 11 \\
\% UFSCar & 0 & 0 & 0 & 9 & 0 & 9 & 18 & 0 & 55 & 0 & 9 & 100 \\
\hline
\end{tabular}

Tabela B.13: Dados referentes à questão 11 do questionário dos gestores dos Programas da USP e da UFSCar.

\begin{tabular}{cccccccccccc|c}
\hline Nota & $\mathbf{0}$ & $\mathbf{1}$ & $\mathbf{2}$ & $\mathbf{3}$ & $\mathbf{4}$ & $\mathbf{5}$ & $\mathbf{6}$ & $\mathbf{7}$ & $\mathbf{8}$ & $\mathbf{9}$ & $\mathbf{1 0}$ & TOTAL \\
\hline USP & 1 & 0 & 1 & 1 & 0 & 1 & 4 & 0 & 5 & 4 & 25 & 42 \\
\% USP & 2 & 0 & 2 & 2 & 0 & 2 & 10 & 0 & 12 & 10 & 60 & 100 \\
\hline UFSCar & 0 & 0 & 0 & 0 & 1 & 2 & 0 & 1 & 2 & 0 & 6 & 12 \\
\% UFSCar & 0 & 0 & 0 & 0 & 8 & 17 & 0 & 8 & 17 & 0 & 50 & 100 \\
\hline
\end{tabular}

Tabela B.14: Dados referentes à questão 12 do questionário dos gestores dos Programas da USP e da UFSCar.

\begin{tabular}{ccc|cc}
\hline Opção & USP & \% USP & UFSCar & \% UFSCar \\
\hline Sim & 30 & 81 & 7 & 58 \\
Não & 7 & 19 & 5 & 42 \\
\hline TOTAL & 37 & 100 & 12 & 100 \\
\hline
\end{tabular}

Tabela B.15: Dados referentes à questão 13 do questionário dos gestores dos Programas da USP e da UFSCar.

\begin{tabular}{cccccccccccc|c}
\hline Nota & $\mathbf{0}$ & $\mathbf{1}$ & $\mathbf{2}$ & $\mathbf{3}$ & $\mathbf{4}$ & $\mathbf{5}$ & $\mathbf{6}$ & $\mathbf{7}$ & $\mathbf{8}$ & $\mathbf{9}$ & $\mathbf{1 0}$ & TOTAL \\
\hline USP & 3 & 0 & 1 & 5 & 1 & 7 & 3 & 2 & 5 & 2 & 9 & 38 \\
\% USP & 8 & 0 & 3 & 13 & 3 & 18 & 8 & 5 & 13 & 5 & 24 & 100 \\
\hline UFSCar & 0 & 0 & 0 & 1 & 0 & 5 & 1 & 3 & 0 & 1 & 0 & 11 \\
\% UFSCar & 0 & 0 & 0 & 9 & 0 & 45 & 9 & 27 & 0 & 9 & 0 & 100 \\
\hline
\end{tabular}


Tabela B.16: Dados referentes à questão 14 do questionário dos gestores dos Programas da USP e da UFSCar.

\begin{tabular}{cccccccccccc|c}
\hline Nota & $\mathbf{0}$ & $\mathbf{1}$ & $\mathbf{2}$ & $\mathbf{3}$ & $\mathbf{4}$ & $\mathbf{5}$ & $\mathbf{6}$ & $\mathbf{7}$ & $\mathbf{8}$ & $\mathbf{9}$ & $\mathbf{1 0}$ & TOTAL \\
\hline USP & 0 & 1 & 0 & 0 & 1 & 2 & 4 & 2 & 8 & 4 & 18 & 40 \\
\% USP & 0 & 3 & 0 & 0 & 3 & 5 & 10 & 5 & 20 & 10 & 45 & 100 \\
\hline UFSCar & 0 & 0 & 0 & 0 & 0 & 1 & 0 & 3 & 5 & 2 & 1 & 12 \\
\% UFSCar & 0 & 0 & 0 & 0 & 0 & 8 & 0 & 25 & 42 & 17 & 8 & 100 \\
\hline
\end{tabular}

Tabela B.17: Dados referentes à questão 15 do questionário dos gestores dos Programas da USP e da UFSCar.

\begin{tabular}{cccccccccccc|c}
\hline Nota & $\mathbf{0}$ & $\mathbf{1}$ & $\mathbf{2}$ & $\mathbf{3}$ & $\mathbf{4}$ & $\mathbf{5}$ & $\mathbf{6}$ & $\mathbf{7}$ & $\mathbf{8}$ & $\mathbf{9}$ & $\mathbf{1 0}$ & TOTAL \\
\hline USP & 2 & 0 & 0 & 0 & 2 & 6 & 1 & 3 & 10 & 3 & 13 & 40 \\
\% USP & 5 & 0 & 0 & 0 & 5 & 15 & 3 & 8 & 25 & 8 & 33 & 100 \\
\hline UFSCar & 2 & 1 & 0 & 3 & 0 & 1 & 0 & 0 & 1 & 2 & 3 & 13 \\
\% UFSCar & 15 & 8 & 0 & 23 & 0 & 8 & 0 & 0 & 8 & 15 & 23 & 100 \\
\hline
\end{tabular}

Tabela B.18: Dados referentes à questão 16 do questionário dos gestores dos Programas da USP e da UFSCar.

\begin{tabular}{cccccccccccc|c}
\hline Nota & $\mathbf{0}$ & $\mathbf{1}$ & $\mathbf{2}$ & $\mathbf{3}$ & $\mathbf{4}$ & $\mathbf{5}$ & $\mathbf{6}$ & $\mathbf{7}$ & $\mathbf{8}$ & $\mathbf{9}$ & $\mathbf{1 0}$ & TOTAL \\
\hline USP & 1 & 0 & 0 & 2 & 1 & 0 & 1 & 1 & 5 & 6 & 24 & 41 \\
\% USP & 2 & 0 & 0 & 5 & 2 & 0 & 2 & 2 & 12 & 15 & 59 & 100 \\
\hline UFSCar & 0 & 0 & 0 & 1 & 1 & 0 & 0 & 3 & 2 & 2 & 4 & 13 \\
\% UFSCar & 0 & 0 & 0 & 8 & 8 & 0 & 0 & 23 & 15 & 15 & 31 & 100 \\
\hline
\end{tabular}

Tabela B.19: Avaliação do questionário dos gestores dos Programas da USP e da UFSCar.

\begin{tabular}{cccccccccccc|c}
\hline Nota & $\mathbf{0}$ & $\mathbf{1}$ & $\mathbf{2}$ & $\mathbf{3}$ & $\mathbf{4}$ & $\mathbf{5}$ & $\mathbf{6}$ & $\mathbf{7}$ & $\mathbf{8}$ & $\mathbf{9}$ & $\mathbf{1 0}$ & TOTAL \\
\hline USP & 0 & 1 & 0 & 1 & 2 & 6 & 4 & 8 & 13 & 2 & 4 & 41 \\
\% USP & 0 & 2 & 0 & 2 & 5 & 15 & 10 & 20 & 32 & 5 & 10 & 100 \\
\hline UFSCar & 0 & 1 & 0 & 0 & 1 & 1 & 1 & 1 & 6 & 1 & 1 & 13 \\
\% UFSCar & 0 & 8 & 0 & 0 & 8 & 8 & 8 & 8 & 46 & 8 & 8 & 100 \\
\hline
\end{tabular}




\section{QUESTIONÁRIO DOS CLIENTES DOS}

\section{RU'S DA USP E DA UFSCar}

Tabela B.20: Dados pessoais dos clientes dos RU's da USP e da UFSCar.

\begin{tabular}{ccc|cc}
\hline Gênero & USP & \% USP & UFSCar & \% UFSCar \\
\hline Feminino & 77 & 22 & 163 & 47 \\
Masculino & 271 & 78 & 183 & 53 \\
\hline TOTAL & 348 & 100 & 346 & 100 \\
\hline
\end{tabular}

Tabela B.21: Dados pessoais dos clientes dos RU's da USP e da UFSCar.

\begin{tabular}{ccc|cc}
\hline Cargo & USP & \% USP & UFSCar & \% UFSCar \\
\hline Aluno Graduação & 286 & 82,9 & 307 & 88,5 \\
$\begin{array}{c}\text { Aluno Pós- } \\
\text { Graduação }\end{array}$ & 56 & 16,2 & 27 & 7,8 \\
Docente & 0 & 0,0 & 1 & 0,3 \\
$\begin{array}{c}\text { Funcionário ou } \\
\text { Terceirizado }\end{array}$ & 3 & 0,9 & 12 & 3,5 \\
\hline TOTAL & 345 & 100,0 & 347 & 100,0 \\
\hline
\end{tabular}

Tabela B.22: Dados referentes à questão 01 do questionário dos clientes dos RU's da USP e da UFSCar.

\begin{tabular}{ccc|cc}
\hline Opção & USP & \% USP & UFSCar & \% UFSCar \\
\hline Sim & 297 & 85 & 117 & 34 \\
Não & 53 & 15 & 230 & 66 \\
\hline TOTAL & 350 & 100 & 347 & 100 \\
\hline
\end{tabular}


Tabela B.23: Dados referentes à questão 02 do questionário dos clientes dos RU's da USP e da UFSCar.

\begin{tabular}{cccccccccccc|c}
\hline Nota & $\mathbf{0}$ & $\mathbf{1}$ & $\mathbf{2}$ & $\mathbf{3}$ & $\mathbf{4}$ & $\mathbf{5}$ & $\mathbf{6}$ & $\mathbf{7}$ & $\mathbf{8}$ & $\mathbf{9}$ & $\mathbf{1 0}$ & TOTAL \\
\hline USP & 49 & 21 & 21 & 26 & 26 & 65 & 22 & 29 & 16 & 0 & 9 & 284 \\
\% USP & 17 & 7 & 7 & 9 & 9 & 23 & 8 & 10 & 6 & 0 & 3 & 100 \\
\hline UFSCar & 23 & 12 & 13 & 14 & 10 & 11 & 12 & 8 & 7 & 1 & 2 & 113 \\
\% UFSCar & 20 & 11 & 12 & 12 & 9 & 10 & 11 & 7 & 6 & 1 & 2 & 100 \\
\hline
\end{tabular}

Tabela B.24: Dados referentes à questão 03 do questionário dos clientes dos RU's da USP e da UFSCar.

\begin{tabular}{ccccccccccccc}
\hline Nota & $\mathbf{0}$ & $\mathbf{1}$ & $\mathbf{2}$ & $\mathbf{3}$ & $\mathbf{4}$ & $\mathbf{5}$ & $\mathbf{6}$ & $\mathbf{7}$ & $\mathbf{8}$ & $\mathbf{9}$ & $\mathbf{1 0}$ & TOTAL \\
\hline USP & 163 & 47 & 23 & 19 & 8 & 16 & 4 & 8 & 3 & 0 & 4 & 295 \\
\% USP & 55 & 16 & 8 & 6 & 3 & 5 & 1 & 3 & 1 & 0 & 1 & 100 \\
\hline UFSCar & 64 & 18 & 10 & 3 & 1 & 9 & 6 & 2 & 3 & 0 & 0 & 116 \\
\% UFSCar & 55 & 16 & 9 & 3 & 1 & 8 & 5 & 2 & 3 & 0 & 0 & 100 \\
\hline
\end{tabular}

Tabela B.25: Dados referentes à questão 04 do questionário dos clientes dos RU's da USP e da UFSCar.

\begin{tabular}{ccc|cc}
\hline Opção & USP & \% USP & UFSCar & \% UFSCar \\
\hline Não & 81 & 28 & 63 & 54 \\
Sim & 213 & 72 & 54 & 46 \\
\hline TOTAL & 294 & 100 & 117 & 100 \\
\hline
\end{tabular}

Tabela B.26: Dados referentes à questão 04 do questionário dos clientes dos RU's da USP e da UFSCar.

\begin{tabular}{ccc|cc}
\hline Divulgação & USP & \% USP & UFSCar & \% UFSCar \\
\hline Internet & 44 & 16 & 10 & 16 \\
Telefone & 4 & 1 & 0 & 0 \\
$\begin{array}{c}\text { Folhetos, } \\
\text { Cartazes } \\
\text { Palestras }\end{array}$ & 186 & 67 & 34 & 53 \\
\hline TOTAL & 42 & 15 & 20 & 31 \\
\hline
\end{tabular}


Tabela B.27: Dados referentes à questão 05 do questionário dos clientes dos RU's da USP e da UFSCar.

\begin{tabular}{cccccccccccccc}
\hline Nota & $\mathbf{0}$ & $\mathbf{1}$ & $\mathbf{2}$ & $\mathbf{3}$ & $\mathbf{4}$ & $\mathbf{5}$ & $\mathbf{6}$ & $\mathbf{7}$ & $\mathbf{8}$ & $\mathbf{9}$ & $\mathbf{1 0}$ & TOTAL \\
\hline USP & 46 & 5 & 14 & 10 & 5 & 41 & 10 & 28 & 40 & 12 & 84 & 295 \\
\% USP & 16 & 2 & 5 & 3 & 2 & 14 & 3 & 9 & 14 & 4 & 28 & 100 \\
\hline UFSCar & 33 & 5 & 10 & 5 & 3 & 9 & 4 & 6 & 7 & 4 & 31 & 117 \\
\% UFSCar & 28 & 4 & 9 & 4 & 3 & 8 & 3 & 5 & 6 & 3 & 26 & 100 \\
\hline
\end{tabular}

Tabela B.28: Dados referentes à questão 06 do questionário dos clientes dos RU's da USP e da UFSCar.

\begin{tabular}{cccccccccccc|c}
\hline Nota & $\mathbf{0}$ & $\mathbf{1}$ & $\mathbf{2}$ & $\mathbf{3}$ & $\mathbf{4}$ & $\mathbf{5}$ & $\mathbf{6}$ & $\mathbf{7}$ & $\mathbf{8}$ & $\mathbf{9}$ & $\mathbf{1 0}$ & TOTAL \\
\hline USP & 23 & 10 & 9 & 11 & 7 & 68 & 19 & 32 & 35 & 13 & 69 & 296 \\
\% USP & 8 & 3 & 3 & 4 & 2 & 23 & 6 & 11 & 12 & 4 & 23 & 100 \\
\hline UFSCar & 18 & 4 & 6 & 3 & 3 & 18 & 7 & 7 & 16 & 6 & 25 & 113 \\
\% UFSCar & 16 & 4 & 5 & 3 & 3 & 16 & 6 & 6 & 14 & 5 & 22 & 100 \\
\hline
\end{tabular}

Tabela B.29: Dados referentes à questão 07 do questionário dos clientes dos RU's da USP e da UFSCar.

\begin{tabular}{cccccccccccccc}
\hline Nota & $\mathbf{0}$ & $\mathbf{1}$ & $\mathbf{2}$ & $\mathbf{3}$ & $\mathbf{4}$ & $\mathbf{5}$ & $\mathbf{6}$ & $\mathbf{7}$ & $\mathbf{8}$ & $\mathbf{9}$ & $\mathbf{1 0}$ & TOTAL \\
\hline USP & 217 & 12 & 15 & 15 & 8 & 19 & 2 & 4 & 0 & 0 & 5 & 297 \\
\% USP & 73 & 4 & 5 & 5 & 3 & 6 & 1 & 1 & 0 & 0 & 2 & 100 \\
\hline UFSCar & 90 & 7 & 4 & 3 & 2 & 3 & 5 & 0 & 0 & 1 & 0 & 115 \\
\% UFSCar & 78 & 6 & 3 & 3 & 2 & 3 & 4 & 0 & 0 & 1 & 0 & 100 \\
\hline
\end{tabular}

Tabela B.30: Dados referentes à questão 08 do questionário dos clientes dos RU's da USP e da UFSCar.

\begin{tabular}{cccccccccccc|c}
\hline Nota & $\mathbf{0}$ & $\mathbf{1}$ & $\mathbf{2}$ & $\mathbf{3}$ & $\mathbf{4}$ & $\mathbf{5}$ & $\mathbf{6}$ & $\mathbf{7}$ & $\mathbf{8}$ & $\mathbf{9}$ & $\mathbf{1 0}$ & TOTAL \\
\hline USP & 14 & 5 & 6 & 10 & 0 & 12 & 4 & 6 & 4 & 3 & 5 & 69 \\
\% USP & 20 & 7 & 9 & 14 & 0 & 17 & 6 & 9 & 6 & 4 & 7 & 100 \\
\hline UFSCar & 3 & 2 & 4 & 3 & 0 & 5 & 3 & 1 & 0 & 1 & 0 & 22 \\
\% UFSCar & 14 & 9 & 18 & 14 & 0 & 23 & 14 & 5 & 0 & 5 & 0 & 100 \\
\hline
\end{tabular}


Tabela B.31: Dados referentes à questão 09 do questionário dos clientes dos RU's da USP e da UFSCar.

\begin{tabular}{cccccccccccc|c}
\hline Nota & $\mathbf{0}$ & $\mathbf{1}$ & $\mathbf{2}$ & $\mathbf{3}$ & $\mathbf{4}$ & $\mathbf{5}$ & $\mathbf{6}$ & $\mathbf{7}$ & $\mathbf{8}$ & $\mathbf{9}$ & $\mathbf{1 0}$ & TOTAL \\
\hline USP & 8 & 1 & 4 & 14 & 8 & 33 & 12 & 23 & 49 & 21 & 112 & 285 \\
\% USP & 3 & 0 & 1 & 5 & 3 & 12 & 4 & 8 & 17 & 7 & 39 & 100 \\
\hline UFSCar & 14 & 2 & 6 & 6 & 7 & 23 & 6 & 9 & 14 & 2 & 17 & 106 \\
\% UFSCar & 13 & 2 & 6 & 6 & 7 & 22 & 6 & 8 & 13 & 2 & 16 & 100 \\
\hline
\end{tabular}

Tabela B.32: Dados referentes à questão 10 do questionário dos clientes dos RU's da USP e da UFSCar.

\begin{tabular}{cccccccccccc|c}
\hline Nota & $\mathbf{0}$ & $\mathbf{1}$ & $\mathbf{2}$ & $\mathbf{3}$ & $\mathbf{4}$ & $\mathbf{5}$ & $\mathbf{6}$ & $\mathbf{7}$ & $\mathbf{8}$ & $\mathbf{9}$ & $\mathbf{1 0}$ & TOTAL \\
\hline USP & 3 & 2 & 1 & 1 & 3 & 18 & 2 & 23 & 34 & 23 & 181 & 291 \\
USP & 1 & 1 & 0 & 0 & 1 & 6 & 1 & 8 & 12 & 8 & 62 & 100 \\
\hline UFSCar & 7 & 2 & 3 & 1 & 4 & 17 & 4 & 7 & 12 & 7 & 41 & 105 \\
UFSCar & 7 & 2 & 3 & 1 & 4 & 16 & 4 & 7 & 11 & 7 & 39 & 100 \\
\hline
\end{tabular}

Tabela B.33: Dados referentes à questão 11 do questionário dos clientes dos RU's da USP e da UFSCar.

\begin{tabular}{cccccccccccc|c}
\hline Nota & $\mathbf{0}$ & $\mathbf{1}$ & $\mathbf{2}$ & $\mathbf{3}$ & $\mathbf{4}$ & $\mathbf{5}$ & $\mathbf{6}$ & $\mathbf{7}$ & $\mathbf{8}$ & $\mathbf{9}$ & $\mathbf{1 0}$ & TOTAL \\
\hline USP & 8 & 4 & 7 & 6 & 5 & 45 & 18 & 41 & 53 & 32 & 74 & 293 \\
\% USP & 3 & 1 & 2 & 2 & 2 & 15 & 6 & 14 & 18 & 11 & 25 & 100 \\
\hline UFSCar & 6 & 3 & 2 & 4 & 2 & 21 & 10 & 12 & 15 & 4 & 27 & 106 \\
\% UFSCar & 6 & 3 & 2 & 4 & 2 & 20 & 9 & 11 & 14 & 4 & 25 & 100 \\
\hline
\end{tabular}

Tabela B34: Avaliação do questionário dos clientes dos RU's da USP e da UFSCar.

\begin{tabular}{cccccccccccc|c}
\hline Nota & $\mathbf{0}$ & $\mathbf{1}$ & $\mathbf{2}$ & $\mathbf{3}$ & $\mathbf{4}$ & $\mathbf{5}$ & $\mathbf{6}$ & $\mathbf{7}$ & $\mathbf{8}$ & $\mathbf{9}$ & $\mathbf{1 0}$ & TOTAL \\
\hline USP & 0 & 1 & 4 & 5 & 3 & 33 & 30 & 69 & 80 & 27 & 38 & 290 \\
\% USP & 0 & 0 & 1 & 2 & 1 & 11 & 10 & 24 & 28 & 9 & 13 & 100 \\
\hline UFSCar & 3 & 0 & 0 & 5 & 4 & 12 & 13 & 20 & 22 & 15 & 11 & 105 \\
\% UFSCar & 3 & 0 & 0 & 5 & 4 & 11 & 12 & 19 & 21 & 14 & 10 & 100 \\
\hline
\end{tabular}




\section{QUESTIONÁRIO DOS FUNCIONÁRIOS DO PROGRAMA \\ DE RECICLAGEM DA USP - USP RECICLA}

\begin{tabular}{ccc}
\hline Tabela B.35: Dados pessoais dos funcionários do Programa da U \\
\hline Gênero & USP & \% USP \\
\hline Feminino & 27 & 54 \\
Masculino & 23 & 46 \\
\hline TOTAL & 50 & 100 \\
\hline
\end{tabular}

Tabela B.36: Dados pessoais dos funcionários do Programa da USP.

\begin{tabular}{ccc}
\hline Cargo & USP & \% USP \\
\hline Aluno Graduação & 10 & 20 \\
$\begin{array}{c}\text { Aluno Pós- } \\
\text { Graduação }\end{array}$ & 2 & 4 \\
Docente & 4 & 8 \\
$\begin{array}{c}\text { Funcionário ou } \\
\text { Terceirizado }\end{array}$ & 34 & 68 \\
\hline TOTAL & 50 & 100 \\
\hline
\end{tabular}

Tabela B.37: Dados referentes à questão 01 do questionário dos funcionários do Programa da USP.

\begin{tabular}{ccc}
\hline Opção & USP & \% USP \\
\hline Sim & 50 & 100 \\
Não & 0 & 0 \\
\hline TOTAL & 50 & 100 \\
\hline
\end{tabular}

Tabela B.38: Dados referentes à questão 02 do questionário dos funcionários do Programa da USP.

\begin{tabular}{cccccccccccccc}
\hline Nota & $\mathbf{0}$ & $\mathbf{1}$ & $\mathbf{2}$ & $\mathbf{3}$ & $\mathbf{4}$ & $\mathbf{5}$ & $\mathbf{6}$ & $\mathbf{7}$ & $\mathbf{8}$ & $\mathbf{9}$ & $\mathbf{1 0}$ & TOTAL \\
\hline USP & 6 & 5 & 4 & 1 & 1 & 8 & 1 & 1 & 3 & 2 & 16 & 48 \\
\% USP & 13 & 10 & 8 & 2 & 2 & 17 & 2 & 2 & 6 & 4 & 33 & 100 \\
\hline
\end{tabular}


Tabela B.39: Dados referentes à questão 03 do questionário dos funcionários do Programa da USP.

\begin{tabular}{ccc} 
Opção & USP & \% USP \\
\hline Não & 2 & 4 \\
Sim & 48 & 96 \\
\hline TOTAL & 50 & 100 \\
\hline
\end{tabular}

Tabela B.40: Dados referentes à questão 03 do questionário dos funcionários do Programa da USP.

\begin{tabular}{ccc} 
Divulgação & USP & \% USP \\
\hline Internet & 36 & 30 \\
Telefone & 14 & 12 \\
$\begin{array}{c}\text { Folhetos, } \\
\text { Cartazes }\end{array}$ & 38 & 32 \\
Palestras & 32 & 27 \\
\hline TOTAL & 120 & 100 \\
\hline
\end{tabular}

Tabela B.41: Dados referentes à questão 04 do questionário dos funcionários do Programa da USP.

\begin{tabular}{ccccccccccccc}
\hline Nota & $\mathbf{0}$ & $\mathbf{1}$ & $\mathbf{2}$ & $\mathbf{3}$ & $\mathbf{4}$ & $\mathbf{5}$ & $\mathbf{6}$ & $\mathbf{7}$ & $\mathbf{8}$ & $\mathbf{9}$ & $\mathbf{1 0}$ & TOTAL \\
\hline USP & 0 & 0 & 1 & 1 & 0 & 1 & 0 & 1 & 2 & 2 & 42 & 50 \\
\% USP & 0 & 0 & 2 & 2 & 0 & 2 & 0 & 2 & 4 & 4 & 84 & 100 \\
\hline
\end{tabular}

Tabela B.42: Dados referentes à questão 05 do questionário dos funcionários do Programa da USP.

\begin{tabular}{cccccccccccccc}
\hline Nota & $\mathbf{0}$ & $\mathbf{1}$ & $\mathbf{2}$ & $\mathbf{3}$ & $\mathbf{4}$ & $\mathbf{5}$ & $\mathbf{6}$ & $\mathbf{7}$ & $\mathbf{8}$ & $\mathbf{9}$ & $\mathbf{1 0}$ & TOTAL \\
\hline USP & 0 & 0 & 0 & 0 & 1 & 2 & 1 & 0 & 5 & 4 & 36 & 49 \\
\% USP & 0 & 0 & 0 & 0 & 2 & 4 & 2 & 0 & 10 & 8 & 73 & 100 \\
\hline
\end{tabular}

Tabela B.43: Dados referentes à questão 06 do questionário dos funcionários do Programa da USP.

\begin{tabular}{ccccccccccccc}
\hline Nota & $\mathbf{0}$ & $\mathbf{1}$ & $\mathbf{2}$ & $\mathbf{3}$ & $\mathbf{4}$ & $\mathbf{5}$ & $\mathbf{6}$ & $\mathbf{7}$ & $\mathbf{8}$ & $\mathbf{9}$ & $\mathbf{1 0}$ & TOTAL \\
\hline USP & 11 & 0 & 1 & 1 & 3 & 5 & 2 & 2 & 7 & 3 & 14 & 49 \\
\% USP & 22 & 0 & 2 & 2 & 6 & 10 & 4 & 4 & 14 & 6 & 29 & 100 \\
\hline
\end{tabular}


Tabela B.44: Dados referentes à questão 07 do questionário dos funcionários do Programa da USP.

\begin{tabular}{cccccccccccc|c}
\hline Nota & $\mathbf{0}$ & $\mathbf{1}$ & $\mathbf{2}$ & $\mathbf{3}$ & $\mathbf{4}$ & $\mathbf{5}$ & $\mathbf{6}$ & $\mathbf{7}$ & $\mathbf{8}$ & $\mathbf{9}$ & $\mathbf{1 0}$ & TOTAL \\
\hline USP & 0 & 0 & 2 & 0 & 0 & 3 & 1 & 4 & 7 & 3 & 17 & 37 \\
\% USP & 0 & 0 & 5 & 0 & 0 & 8 & 3 & 11 & 19 & 8 & 46 & 100 \\
\hline
\end{tabular}

Tabela B.45: Dados referentes à questão 08 do questionário dos funcionários do Programa da USP.

\begin{tabular}{ccc} 
Opção & USP & \% USP \\
\hline Sim & 43 & 88 \\
Não & 6 & 12 \\
\hline TOTAL & 49 & 100 \\
\hline
\end{tabular}

Tabela B.46: Dados referentes à questão 09 do questionário dos funcionários do Programa da USP.

\begin{tabular}{cccccccccccc|c}
\hline Nota & $\mathbf{0}$ & $\mathbf{1}$ & $\mathbf{2}$ & $\mathbf{3}$ & $\mathbf{4}$ & $\mathbf{5}$ & $\mathbf{6}$ & $\mathbf{7}$ & $\mathbf{8}$ & $\mathbf{9}$ & $\mathbf{1 0}$ & TOTAL \\
\hline USP & 0 & 1 & 0 & 0 & 0 & 1 & 2 & 1 & 11 & 3 & 28 & 47 \\
\% USP & 0 & 2 & 0 & 0 & 0 & 2 & 4 & 2 & 23 & 6 & 60 & 100 \\
\hline
\end{tabular}

Tabela B.47: Dados referentes à questão 10 do questionário dos funcionários do Programa da USP.

\begin{tabular}{cccccccccccccc}
\hline Nota & $\mathbf{0}$ & $\mathbf{1}$ & $\mathbf{2}$ & $\mathbf{3}$ & $\mathbf{4}$ & $\mathbf{5}$ & $\mathbf{6}$ & $\mathbf{7}$ & $\mathbf{8}$ & $\mathbf{9}$ & $\mathbf{1 0}$ & TOTAL \\
\hline USP & 0 & 0 & 0 & 0 & 0 & 1 & 0 & 4 & 7 & 8 & 28 & 48 \\
\% USP & 0 & 0 & 0 & 0 & 0 & 2 & 0 & 8 & 15 & 17 & 58 & 100 \\
\hline
\end{tabular}

Tabela B.48: Dados referentes à questão 11 do questionário dos funcionários do Programa da USP.

\begin{tabular}{cccccccccccccc}
\hline Nota & $\mathbf{0}$ & $\mathbf{1}$ & $\mathbf{2}$ & $\mathbf{3}$ & $\mathbf{4}$ & $\mathbf{5}$ & $\mathbf{6}$ & $\mathbf{7}$ & $\mathbf{8}$ & $\mathbf{9}$ & $\mathbf{1 0}$ & TOTAL \\
\hline USP & 0 & 2 & 3 & 0 & 2 & 9 & 5 & 0 & 4 & 5 & 18 & 48 \\
\% USP & 0 & 4 & 6 & 0 & 4 & 19 & 10 & 0 & 8 & 10 & 38 & 100 \\
\hline
\end{tabular}

Tabela B.49: Dados referentes à questão 12 do questionário dos funcionários do Programa da USP.

\begin{tabular}{cccccccccccc|c}
\hline Nota & $\mathbf{0}$ & $\mathbf{1}$ & $\mathbf{2}$ & $\mathbf{3}$ & $\mathbf{4}$ & $\mathbf{5}$ & $\mathbf{6}$ & $\mathbf{7}$ & $\mathbf{8}$ & $\mathbf{9}$ & $\mathbf{1 0}$ & TOTAL \\
\hline USP & 0 & 0 & 0 & 1 & 0 & 0 & 3 & 0 & 5 & 4 & 35 & 48 \\
\% USP & 0 & 0 & 0 & 2 & 0 & 0 & 6 & 0 & 10 & 8 & 73 & 100 \\
\hline
\end{tabular}


Tabela B.50: Avaliação do questionário dos funcionários do Programa da USP.

\begin{tabular}{cccccccccccc|c}
\hline Nota & $\mathbf{0}$ & $\mathbf{1}$ & $\mathbf{2}$ & $\mathbf{3}$ & $\mathbf{4}$ & $\mathbf{5}$ & $\mathbf{6}$ & $\mathbf{7}$ & $\mathbf{8}$ & $\mathbf{9}$ & $\mathbf{1 0}$ & TOTAL \\
\hline USP & 0 & 0 & 0 & 2 & 0 & 5 & 6 & 4 & 14 & 8 & 9 & 48 \\
\% USP & 0 & 0 & 0 & 4 & 0 & 10 & 13 & 8 & 29 & 17 & 19 & 100 \\
\hline
\end{tabular}

